\title{
PARFUME User's Guide
}

September 2010

The INL is a

U.S. Department of Energy National Laboratory

operated by

Battelle Energy Alliance

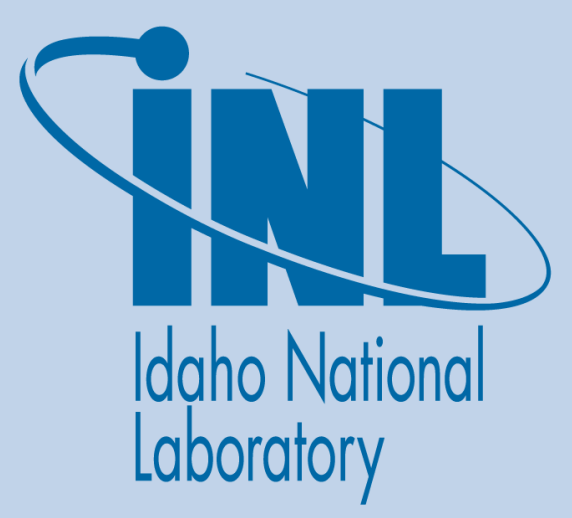

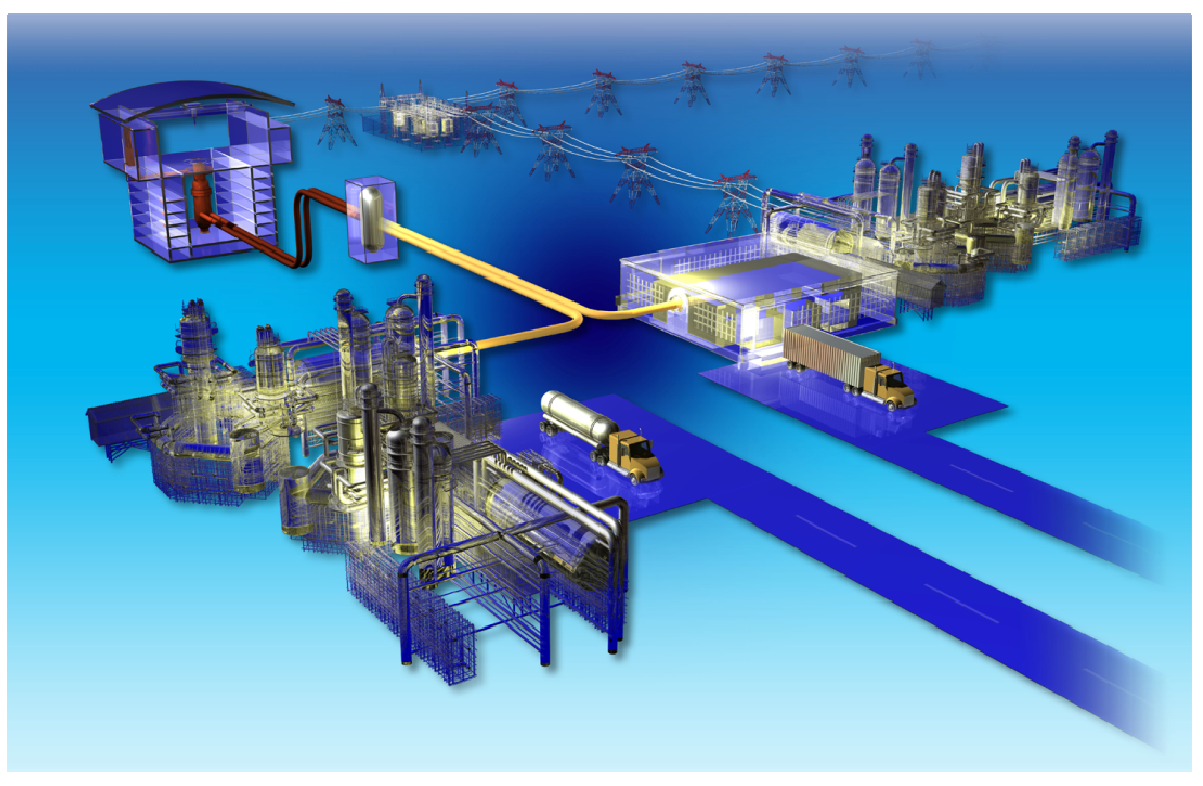




\section{DISCLAIMER}

This information was prepared as an account of work sponsored by an agency of the U.S. Government. Neither the U.S. Government nor any agency thereof, nor any of their employees, makes any warranty, expressed or implied, or assumes any legal liability or responsibility for the accuracy, completeness, or usefulness, of any information, apparatus, product, or process disclosed, or represents that its use would not infringe privately owned rights. References herein to any specific commercial product, process, or service by trade name, trade mark, manufacturer, or otherwise, does not necessarily constitute or imply its endorsement, recommendation, or favoring by the U.S. Government or any agency thereof. The views and opinions of authors expressed herein do not necessarily state or reflect those of the U.S. Government or any agency thereof. 


\title{
PARFUME User's Guide
}

\author{
PARFUME Development Team
}

September 2010

\section{Idaho National Laboratory Next Generation Nuclear Plant Project Idaho Falls, Idaho 83415}

\author{
Prepared for the \\ U.S. Department of Energy \\ Office of Nuclear Energy \\ Under DOE Idaho Operations Office \\ Contract DE-AC07-05ID14517
}





\title{
Next Generation Nuclear Plant Project
}

\author{
PARFUME User's Guide
}

INL/EXT-10-18317

September 2010

Approved by:

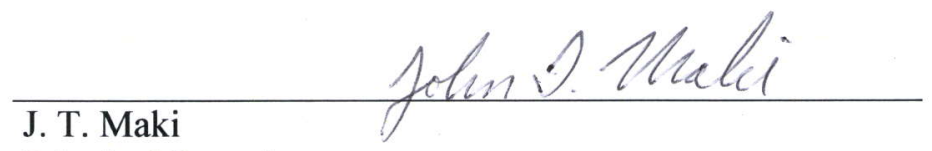

Principal Investigator
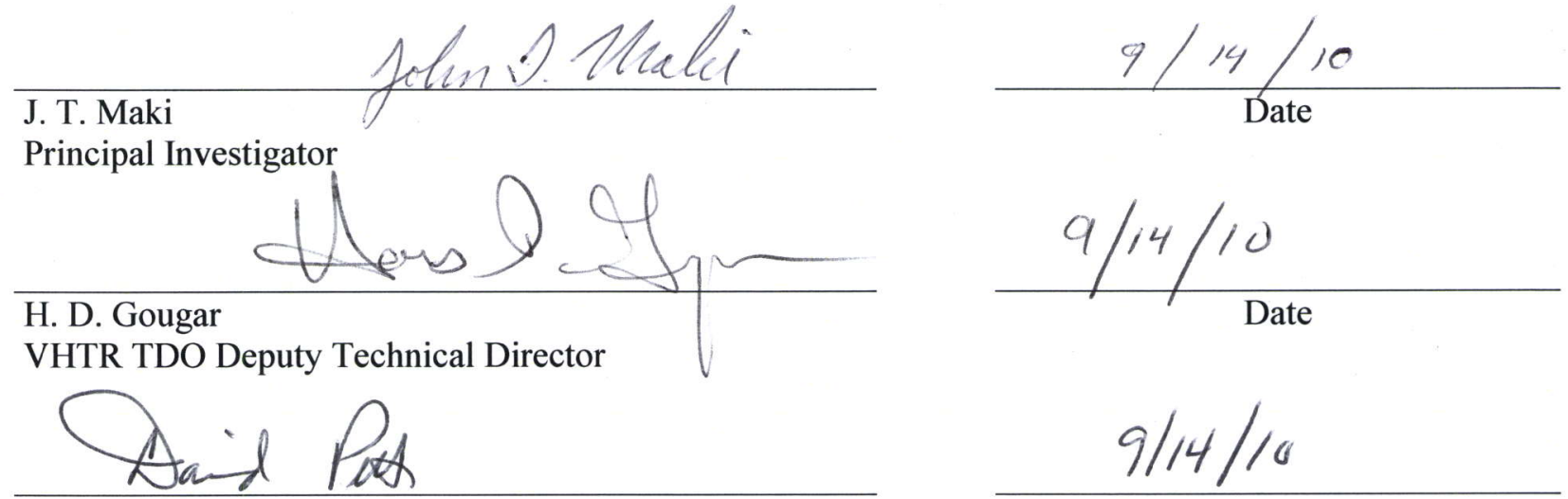

D. A. Petti

VHTR TDO Technical Director
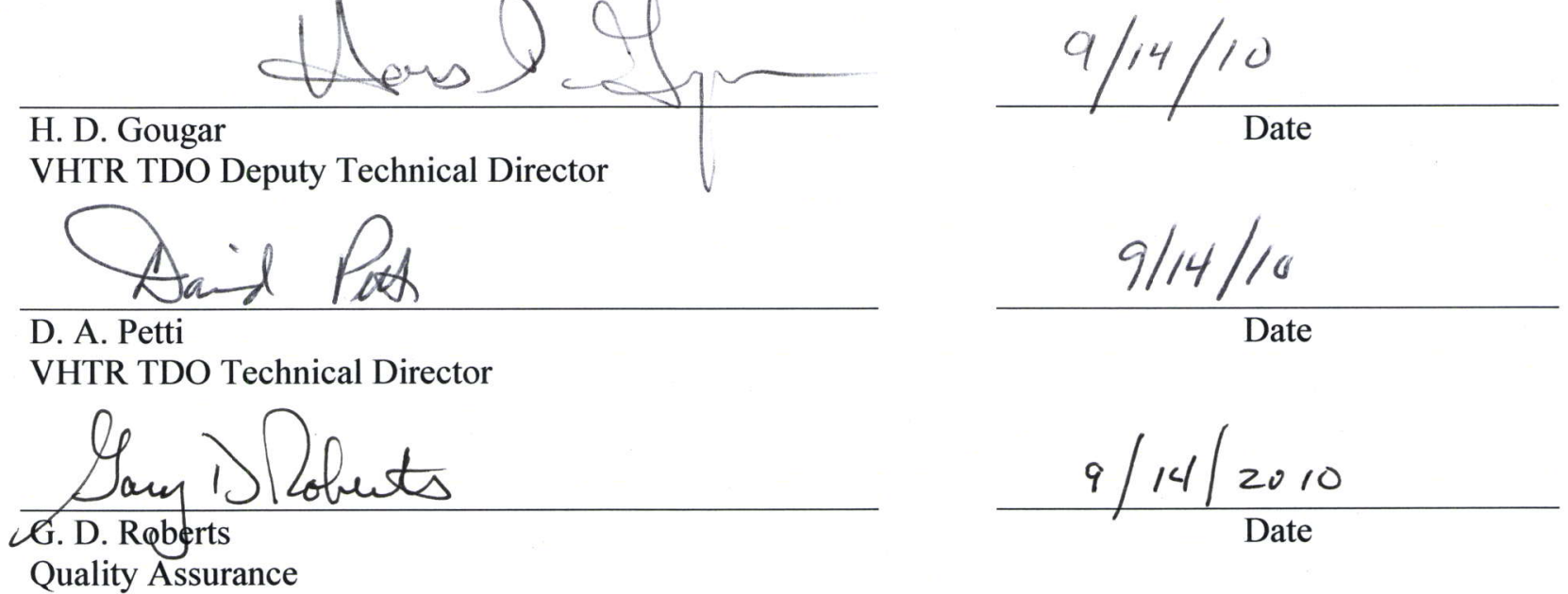

$\frac{9 / 14 / 2010}{\text { Date }}$ 



\begin{abstract}
PARFUME, a fuel performance analysis and modeling code, is being developed at Idaho National Laboratory (INL) for evaluating gas-reactor coated particle fuel for prismatic, pebble bed, and plate type fuel geometries. The code is an integrated mechanistic analysis tool that evaluates the thermal, mechanical, and physico-chemical behavior of (tri-isotropic [TRISO]) coated fuel particles and the probability for fuel failure given the particle-to-particle statistical variations in physical dimensions and material properties that arise during the fuel fabrication process. Using a robust finite difference numerical scheme, PARFUME is capable of performing steady-state and transient heat transfer and fission-product diffusion analyses for the fuel. Written in FORTRAN 77, PARFUME compiles in FORTRAN 90 and is easy to read, maintain, and modify. Currently, PARFUME is supported only on Linux platforms.

This document represents the initial version of the PARFUME User's Guide. The PARFUME Theory and Model Basis Report describes the theoretical aspects of the code. User information is provided, including: (1) code development, (2) capabilities and limitations, (3) installation and execution, (4) user input and output, (5) error messages, and (6) a sample problem.
\end{abstract}




\section{CONTENTS}

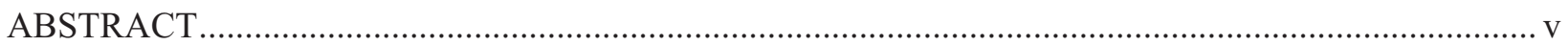

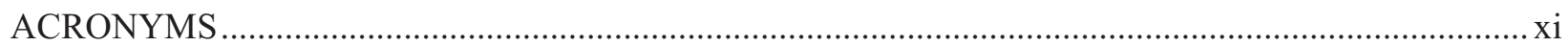

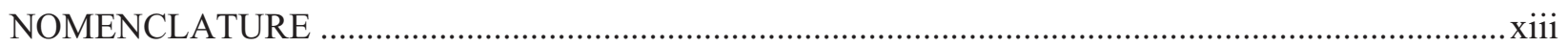

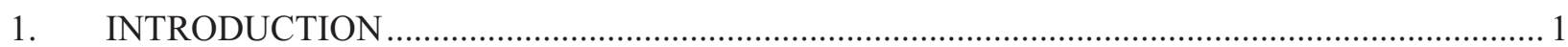

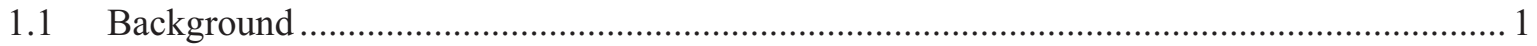

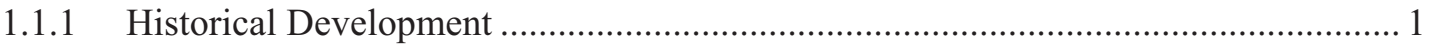

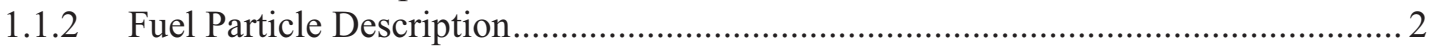

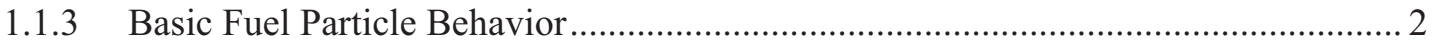

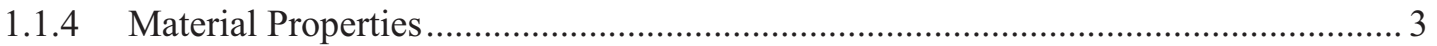

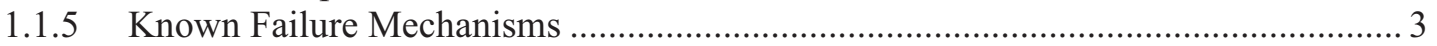

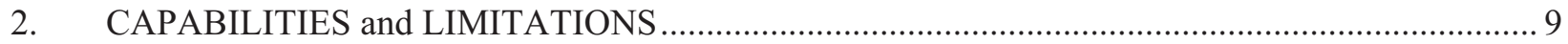

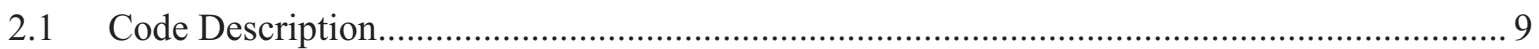

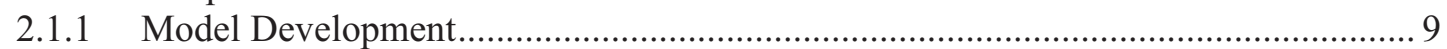

2.1.2 General Solution Procedure …………….................................................... 9

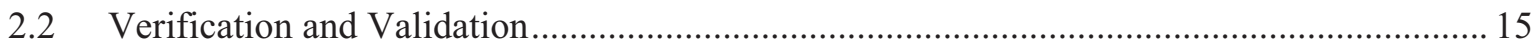

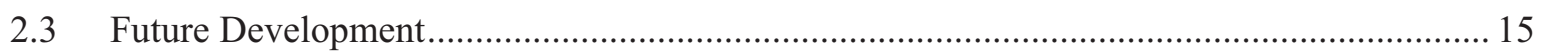

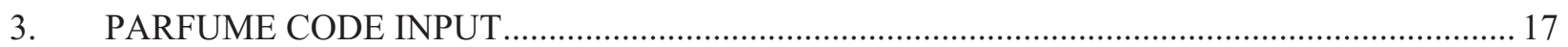

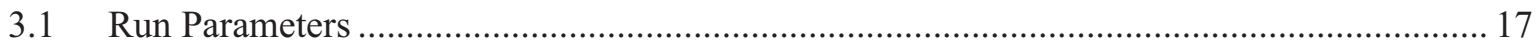

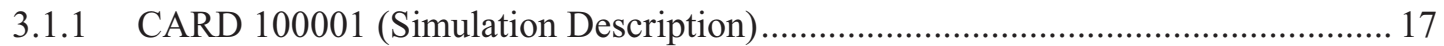

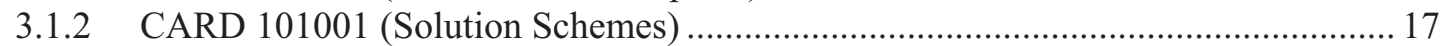

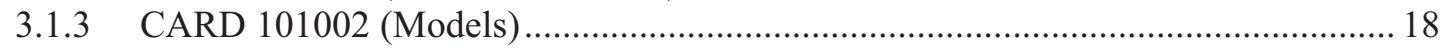

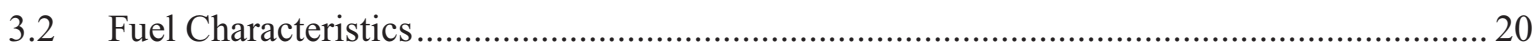

3.2.1 CARD 102001 (Fuel Properties) ...................................................................... 20

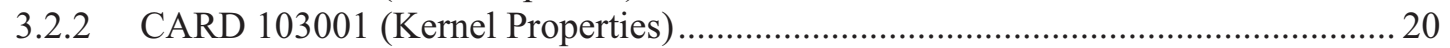

3.2.3 CARD 103002 (Buffer Properties) .................................................................... 21

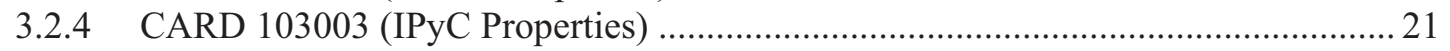

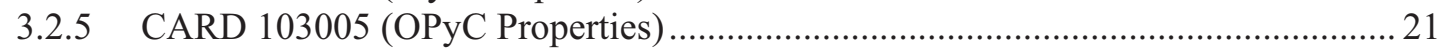

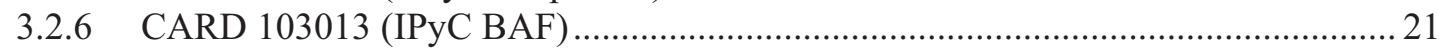

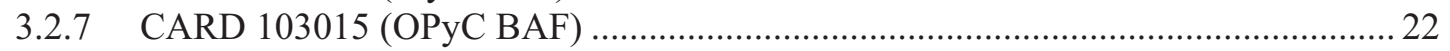

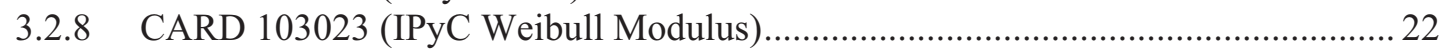

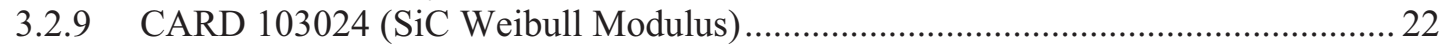

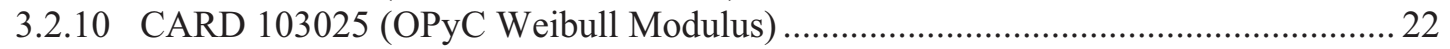

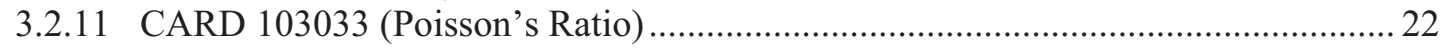

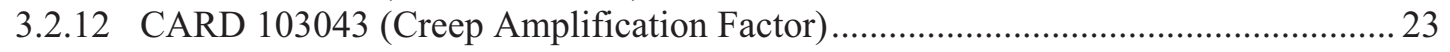

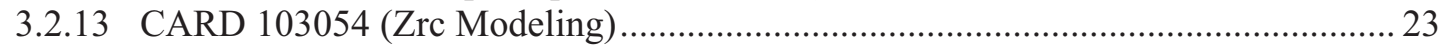

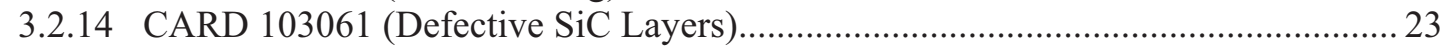

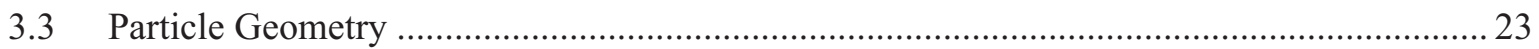

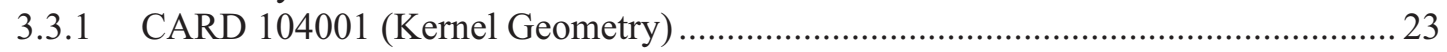

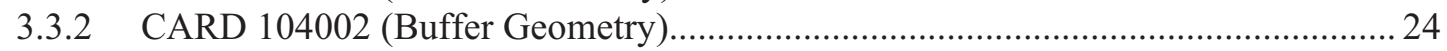

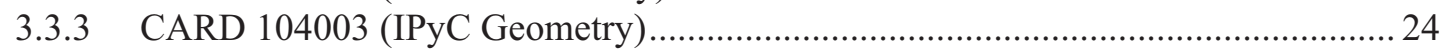

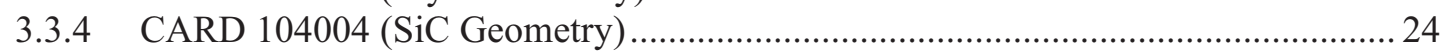

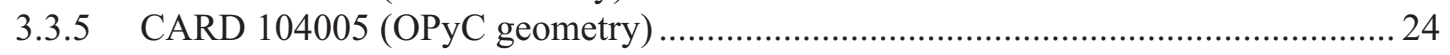




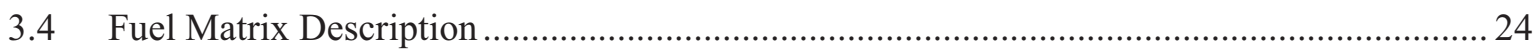

3.4.1 CARD 105001 (Fuel Element Types) ………………………………………...2

3.4.2 CARD 105011 (PEBBLEBED - Particle Density and Mesh) ……………………...2 25

3.4.3 CARD 105021 (PEBBLEBED - Geometry) ……………………………………. 25

3.4.4 CARD 105031 (PEBBLEBED - Density) .............................................................2.

3.4.5 3.4.5. CARD 105041 (PEBBLEBED - Uranium Contamination) ………………....2 25

3.4.6 CARD 105011 (PRISMATIC - Particle Density and Mesh) .................................... 26

3.4.7 CARD 105021 (PRISMATIC - Geometry) ……………………………………..... 26

3.4.8 CARD 105031 (PRISMATIC - Density) …………………………………….....2

3.4.9 CARD 105041 (PRISMATIC - Uranium Contamination) ...........................................2 27

3.4.10 CARD 105011 (PLANEGEOM - Particle Density and Mesh) ……………………....2 27

3.4.11 CARD 105021 (PLANEGEOM - Geometry) …………………………………..... 27

3.4.12 CARD 105031 (PLANEGEOM - Density) …………………………………….....2.

3.4.13 CARD 105041 (PLANEGEOM - Uranium Contamination) ………………………. 28

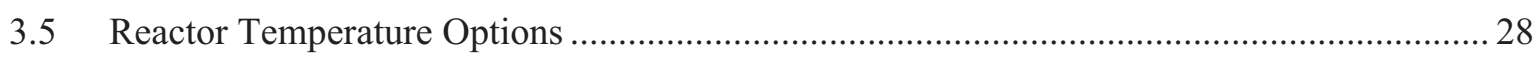

3.5.1 CARD 106001 (Reactor Temperature Options) ……………………………….... 28

3.5.2 CARD 106021 (Global Node Temperatures) …………………………………..... 29

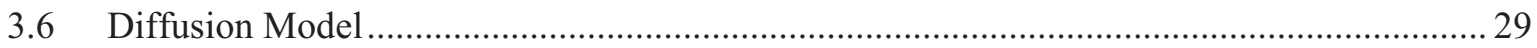

3.6.1 CARD 201001 (Diffusion Model) …………………………………………....2 29

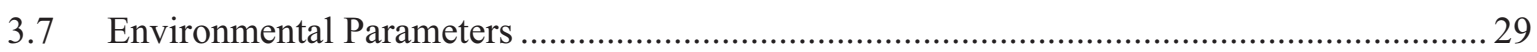

3.7.1 CARD 301001 (Fluence v. Time Input) ……………………………………….....2 29

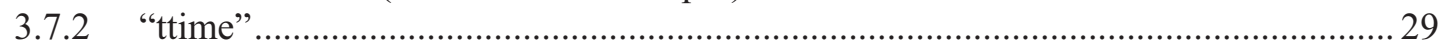

3.7 .3 "flu"

3.7.4 CARD 302001 (Burnup v. Fluence Input) …………………………………………. 29

3.7.5 CARD 303001 (External Pressure v. Fluence Input) .................................................. 30

3.7.6 CARD 304001 (Boundary Temperature v- Fluence Input) ……………………….... 30

3.7.7 CARD 306001 (Time Heatup Starts and Irradiation Ends) ...................................... 30

3.8 Correlation Parameters and Coefficients ........................................................................... 30

3.8.1 CARD 401001 (Correlation Coefficients - IPyC Cracking) ……………………....... 30

3.8.2 CARDS 401002 through 401012 (Correlation Coefficients "c1c", "c2c")................31

3.8.3 CARD 402001 (Correlation Coefficients - Asphericity) ................................................31

3.8.4 CARD 403001 (Correlation Coefficients - Partial IPyC Debonding) ........................ 31

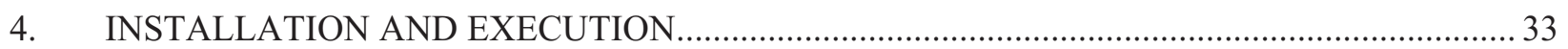

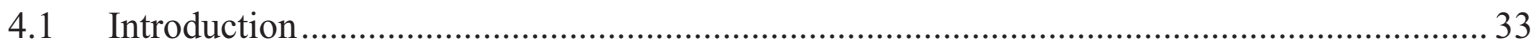

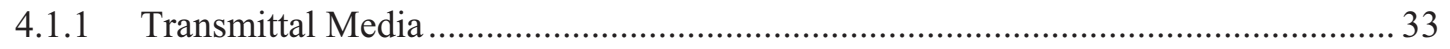

4.1.2 Hardware/Software Requirements ..................................................................... 33

4.1.3 Linux Quick Installation Guide ............................................................................ 33

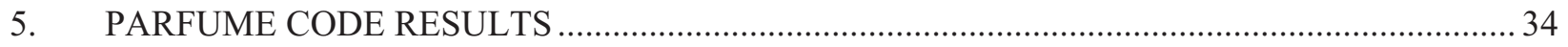

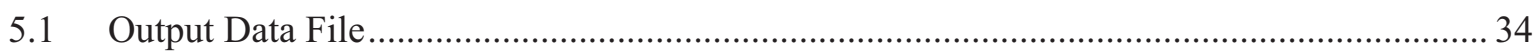

5.1.1 Irradiation History Derived from Input................................................................ 34

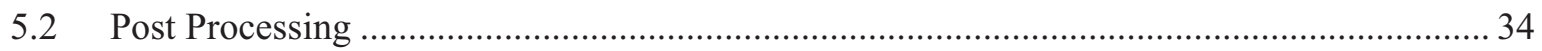

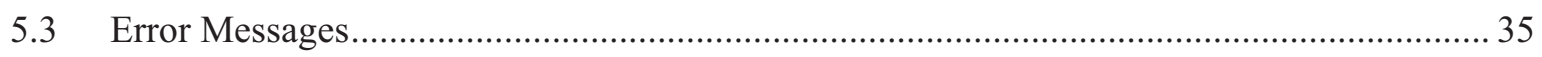

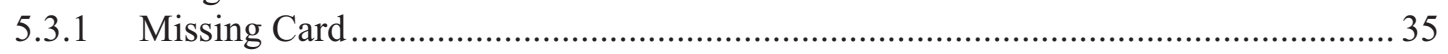

5.3.2 Invalid Inputs Example ……………………………………………………… 35

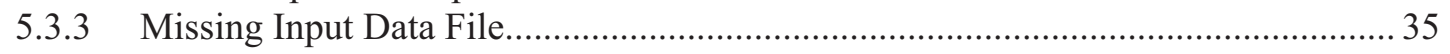

5.3.4 Missing ABAQUS data file ………………………………………………..... 36

5.3.5 Fuel Element Node Mismatch................................................................................... 36 


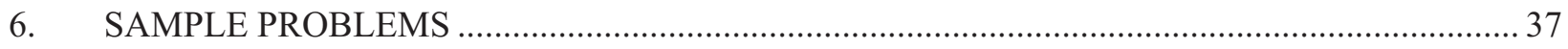

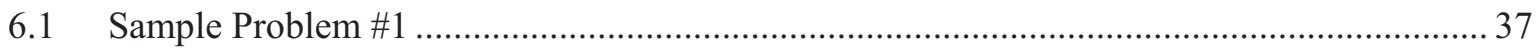

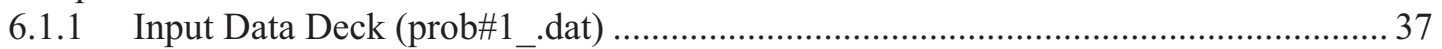

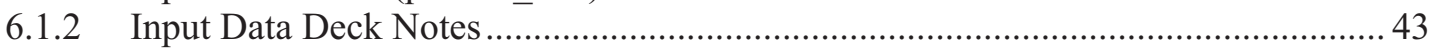

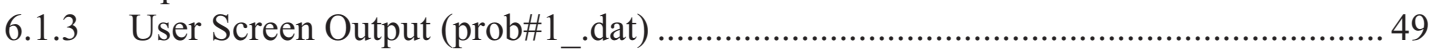

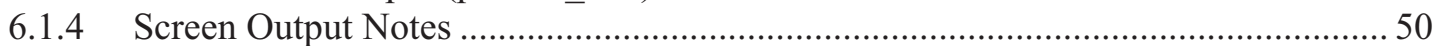

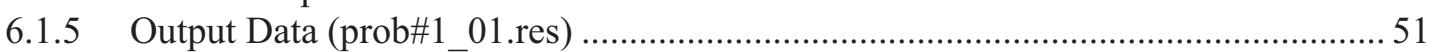

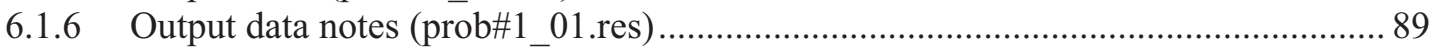

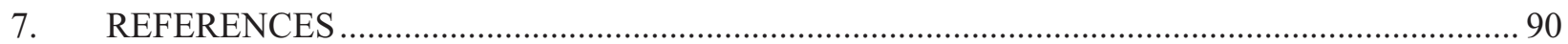

Appendix A Input Parameter Summary ....................................................................................... A-1

\section{FIGURES}

Figure 1-1. Typical TRISO-coated fuel particle geometry. .................................................................2

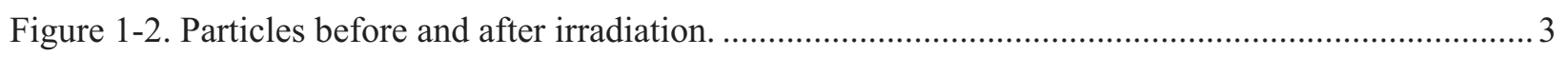

Figure 1-3. Radial and tangential irradiation-induced strains in PyC .................................................... 4

Figure 1-4. Irradiation-induced creep constant for PyC ...................................................................... 5

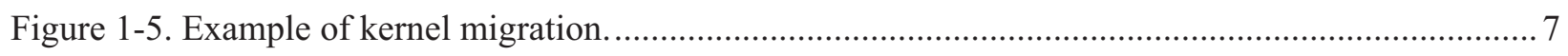

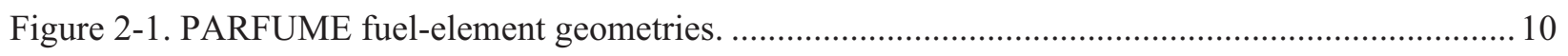

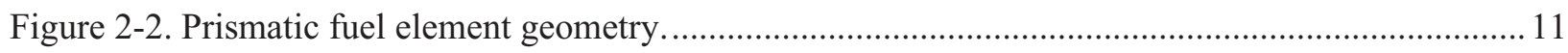

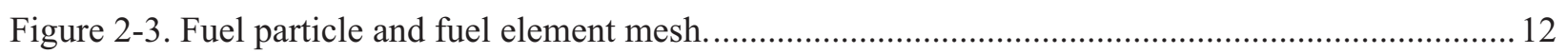

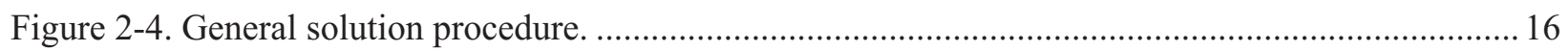

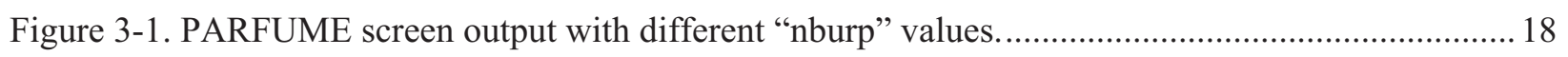

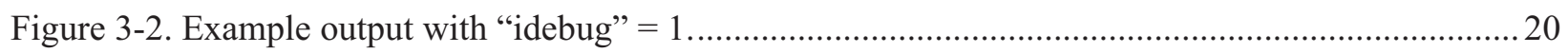

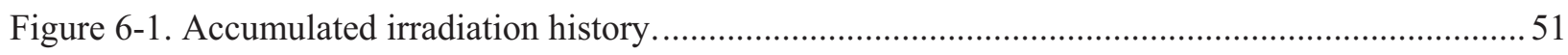

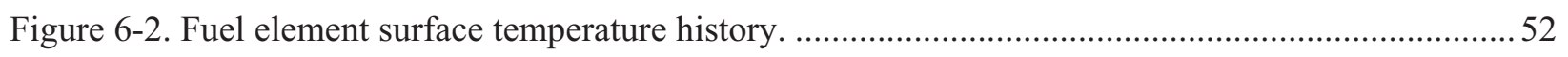

Figure 6-3. Fuel element surface temperature history (heatup)........................................................ 52

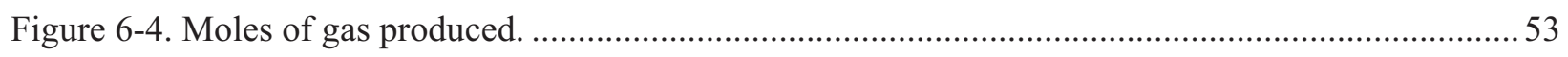

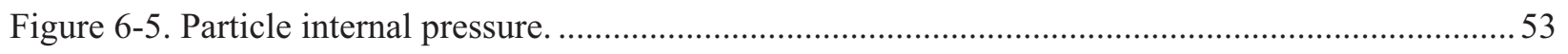

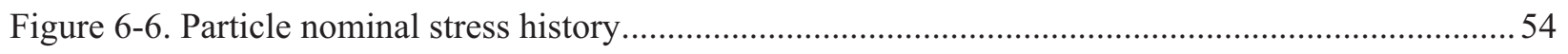

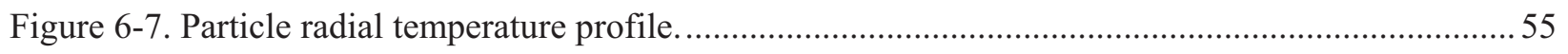

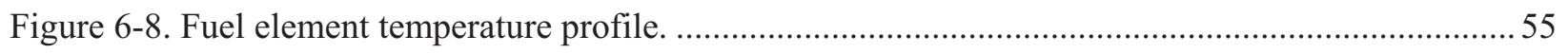

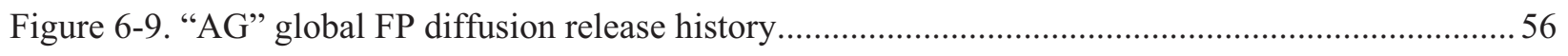

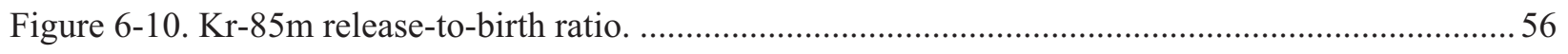

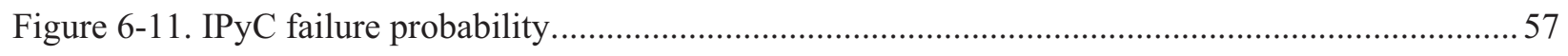

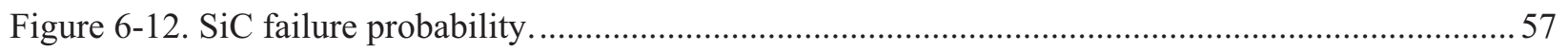




\section{TABLES}

Table 1-1. Comparison of fission gas pressures in a German particle...................................................... 5

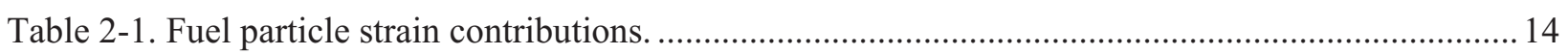

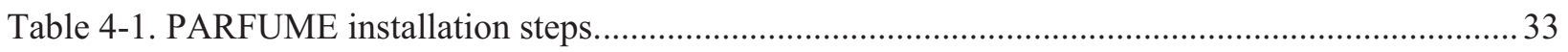

Table A-1. Input data deck parameter summary............................................................................... 


\section{ACRONYMS}

AIAA American Institute of Aeronautics and Astronautics

ANSI American National Standards Institute

ATR Advanced Test Reactor

BAF Bacon Anisotropy Factor

BISO bistructrual-isotropic

CAE computer-aided engineering

CFP coated fuel particle

$\mathrm{CO} \quad$ carbon monoxide

dtf designed to fail

EPRI Electric Power Research Institute

FALCON Fuel Performance Analysis Capability

FIMA fission per initial metallic atom

FP fission product

FZJ Forschungszentrum Juelich

INL Idaho National Laboratory

IPyC inner pyrolytic carbon

JAERI Japan Atomic Energy Research Institute

OECD Organization for Economic Cooperation and Development

NP-MHTGR New Production Modular High-temperature Gas-cooled Reactor

$\mathrm{OPyC} \quad$ outer pyrolytic carbon

PARFUME PARticle FUel ModEl

PIE post-irradiation examination

PNNL Pacific Northwest National Laboratory

PyC pyrolytic carbon

$\mathrm{R} / \mathrm{B} \quad$ release-to-birth

$\mathrm{SiC} \quad$ silicon carbide

TDO Technology Development Office

TRISO tristructural-isotropic

UCO uranium carbide

$\mathrm{UO}_{2} \quad$ uranium oxide

VHTR Very High Temperature Reactor 


\section{NOMENCLATURE}

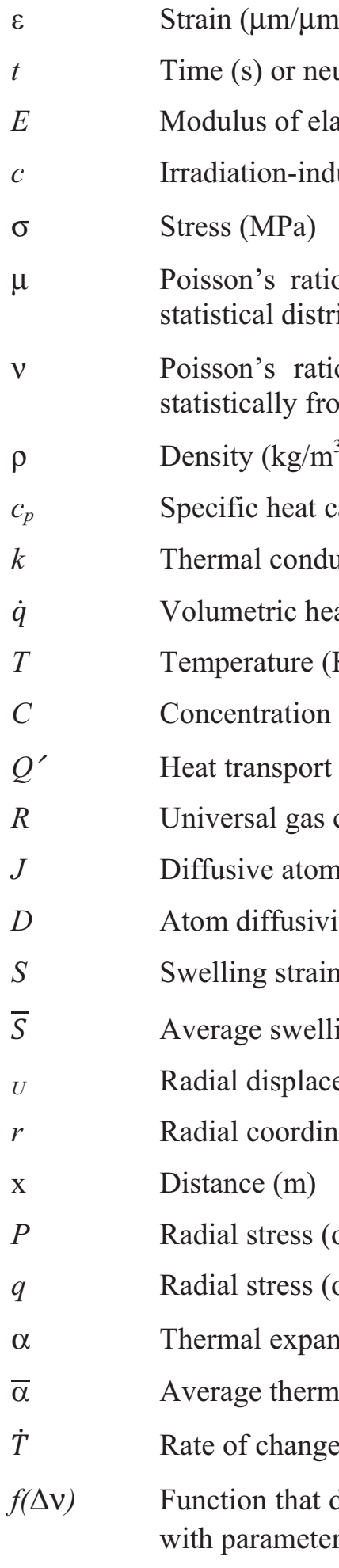

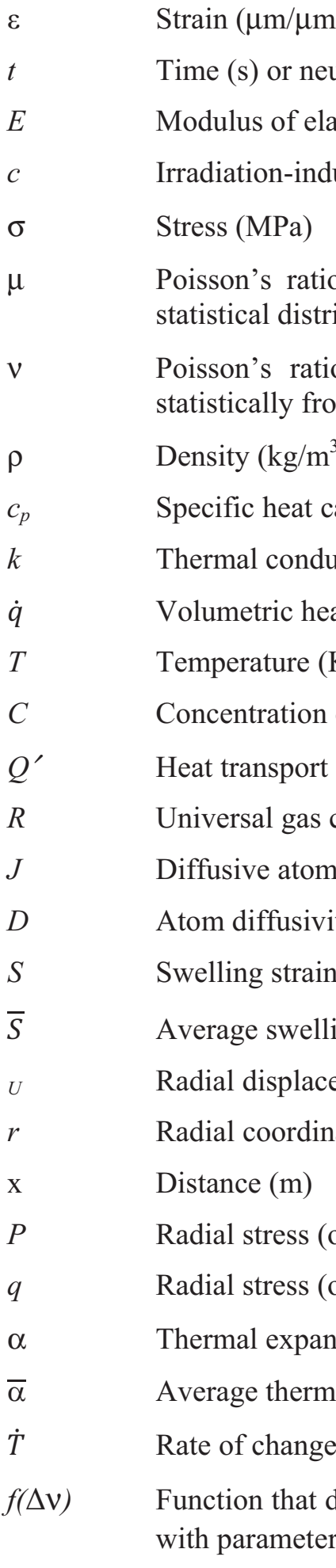

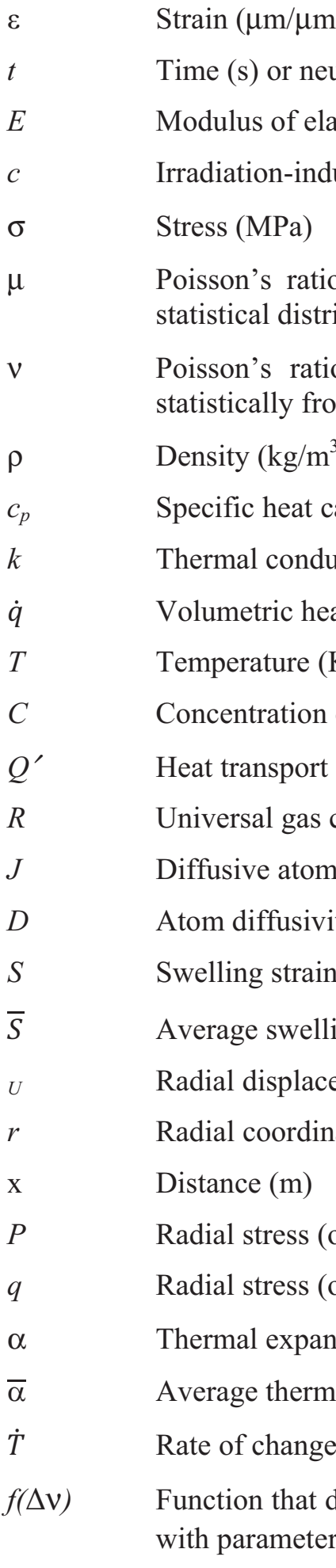

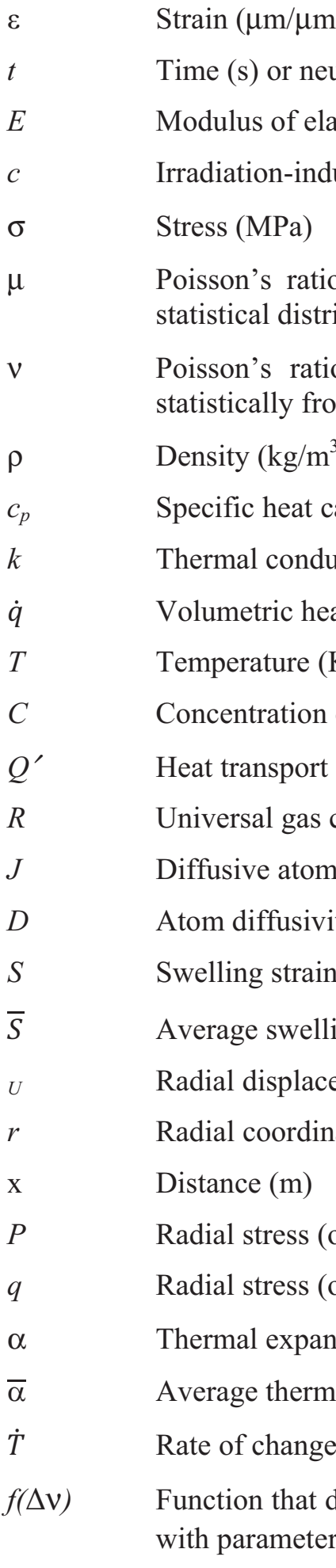

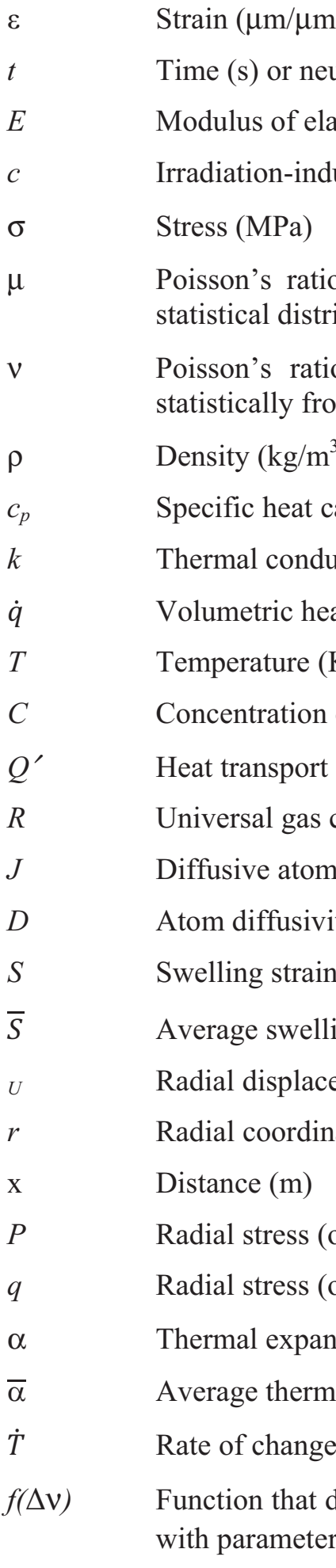

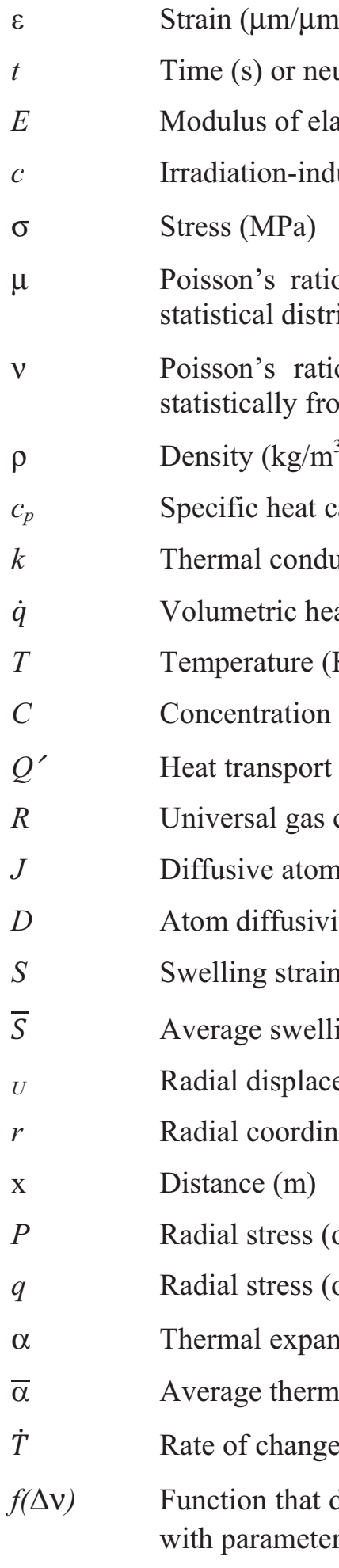

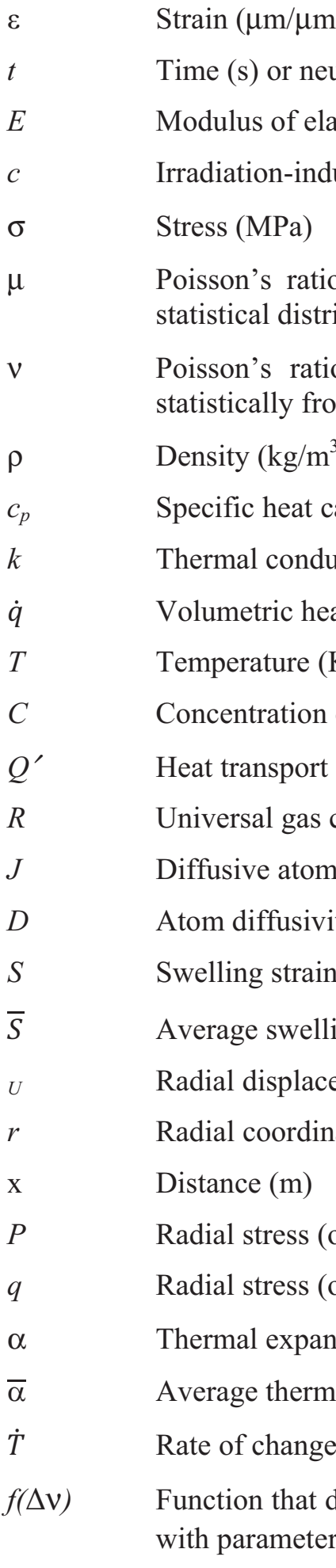

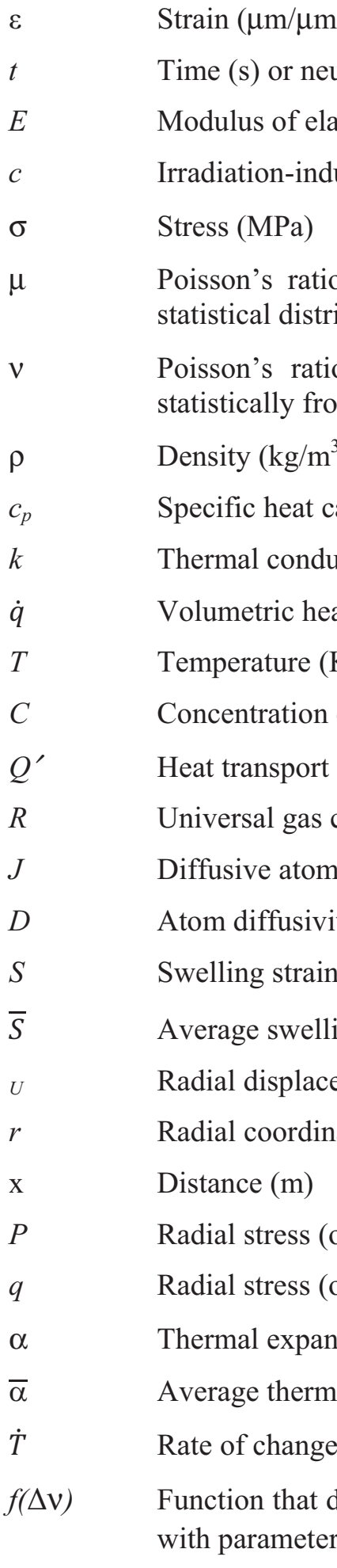

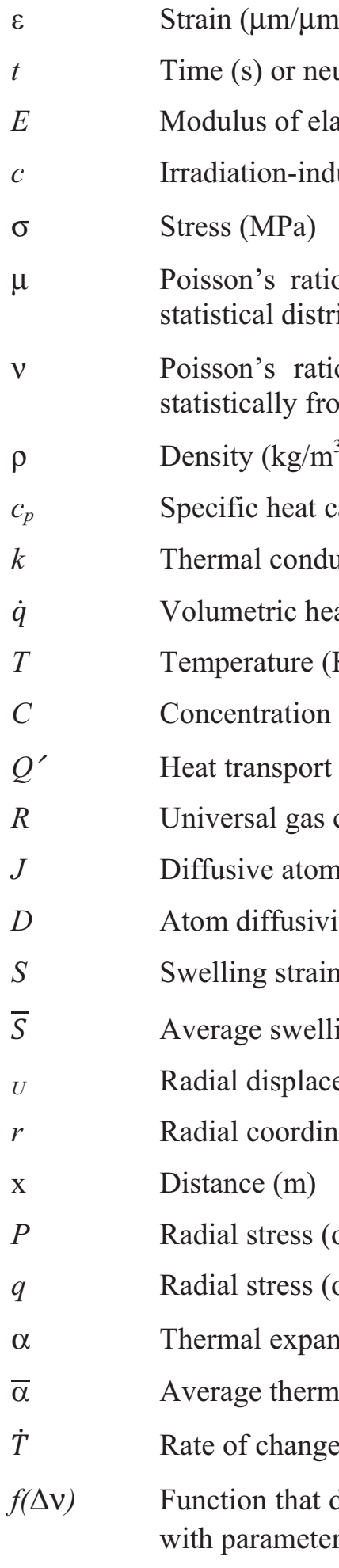

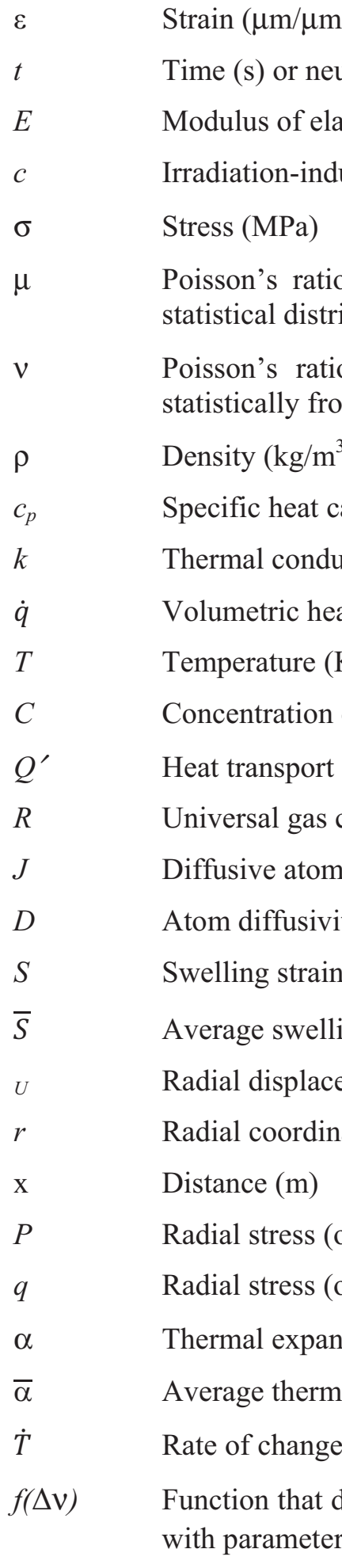

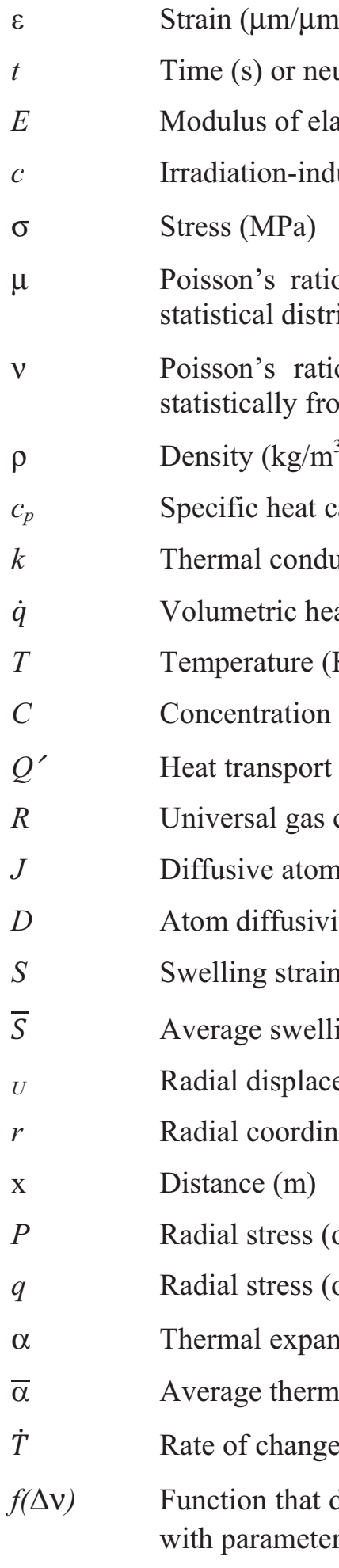

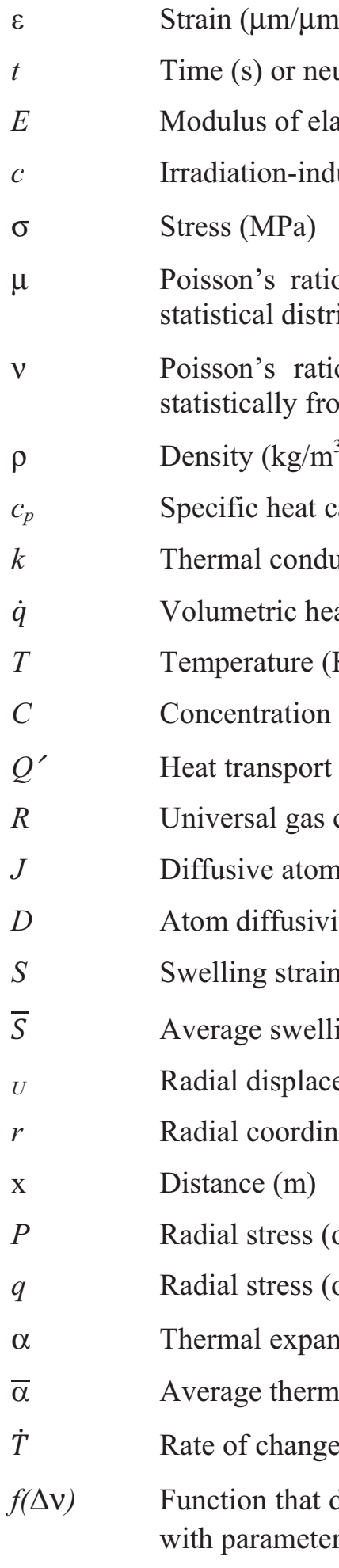

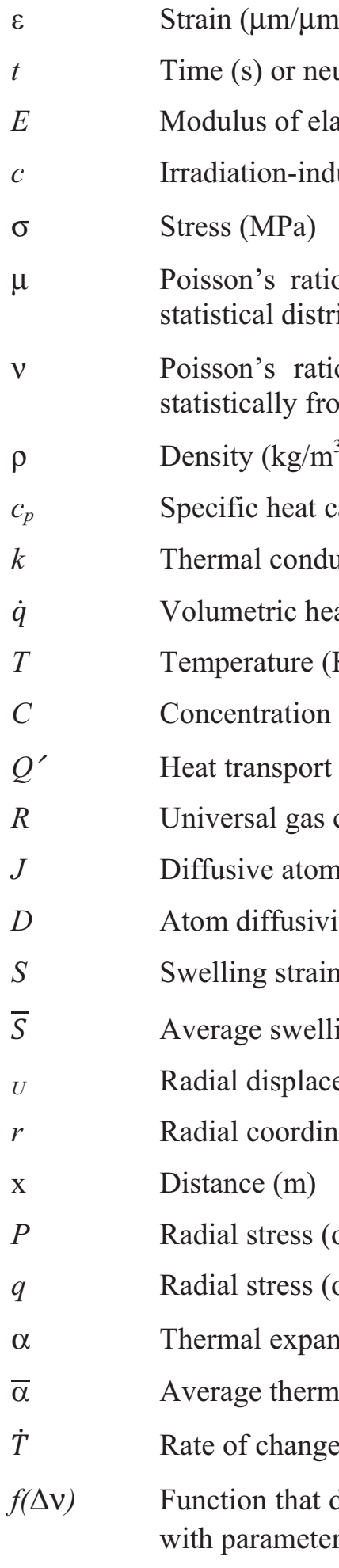

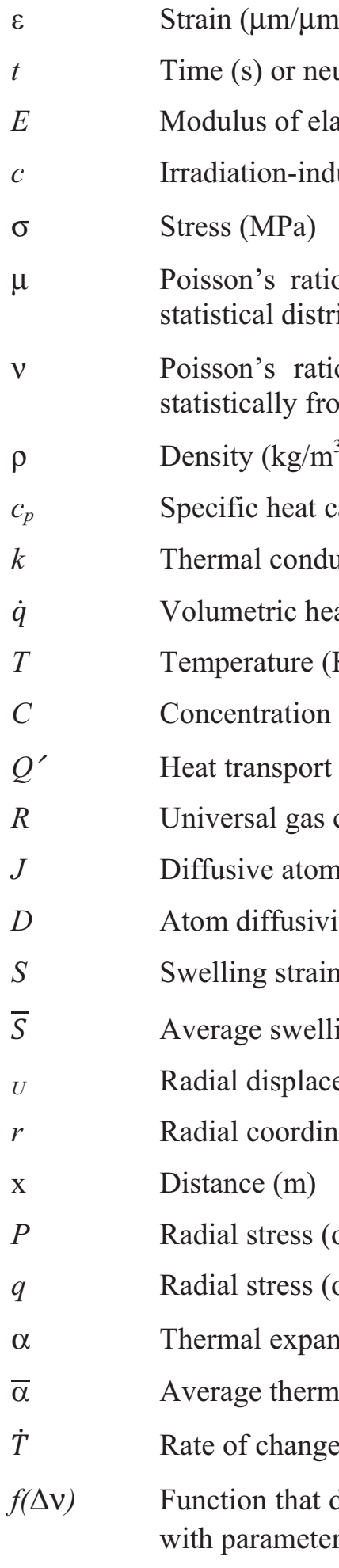

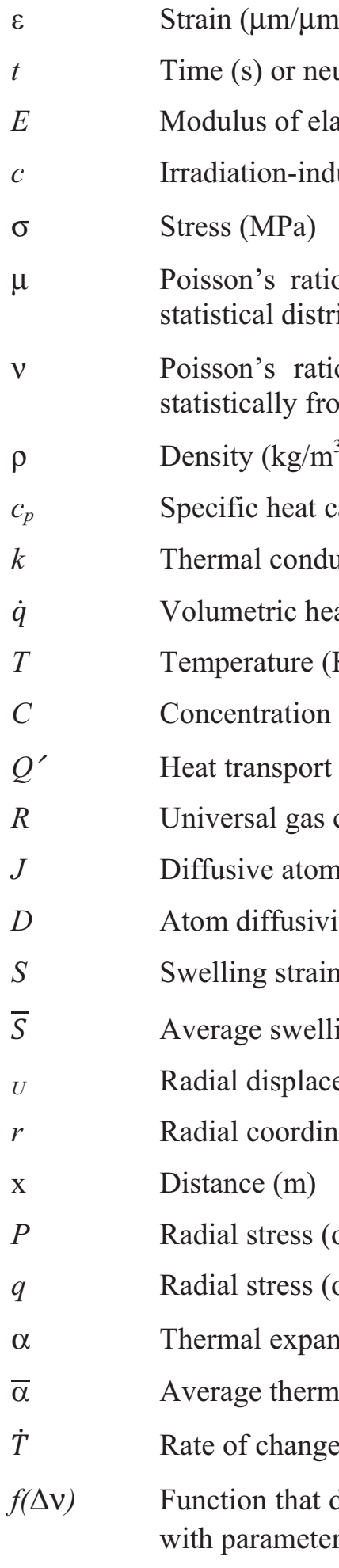

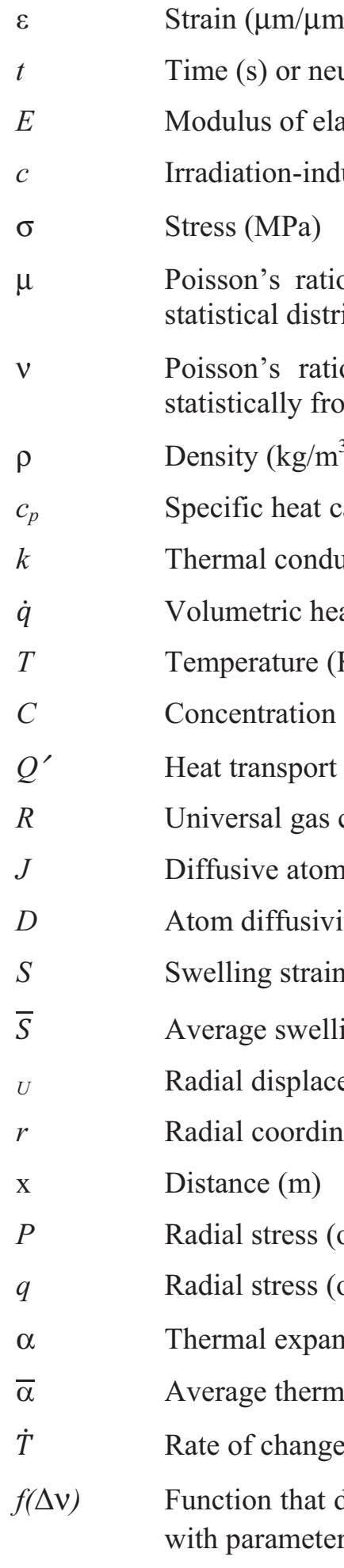

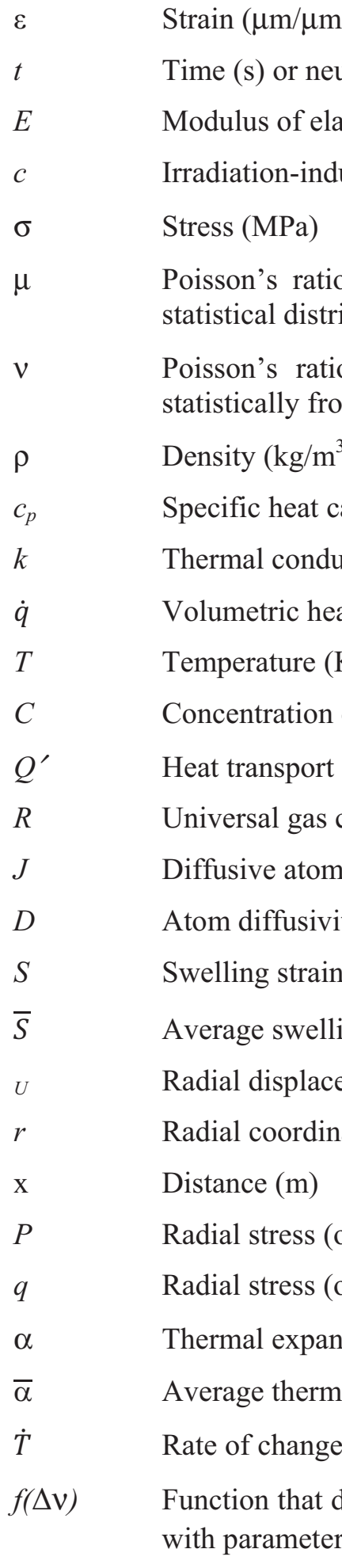

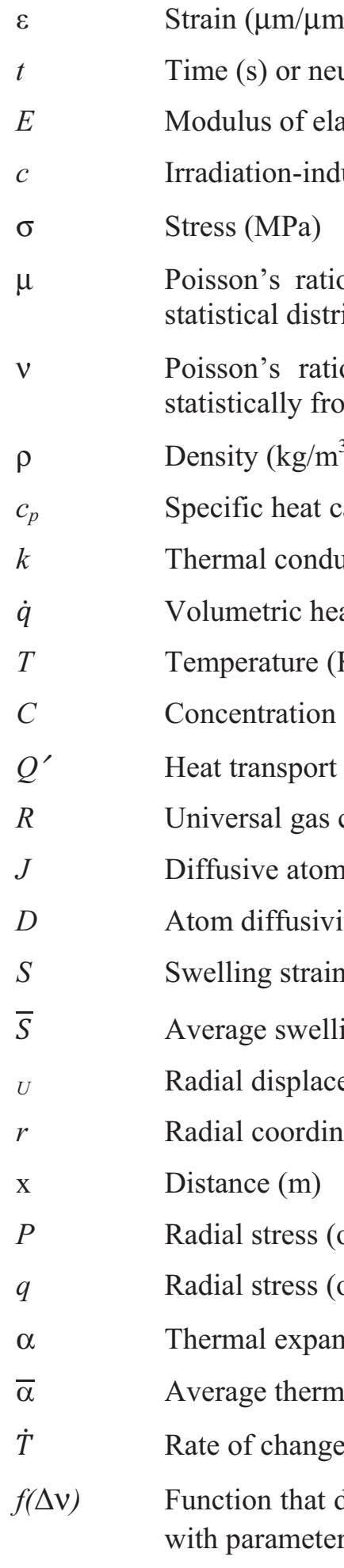

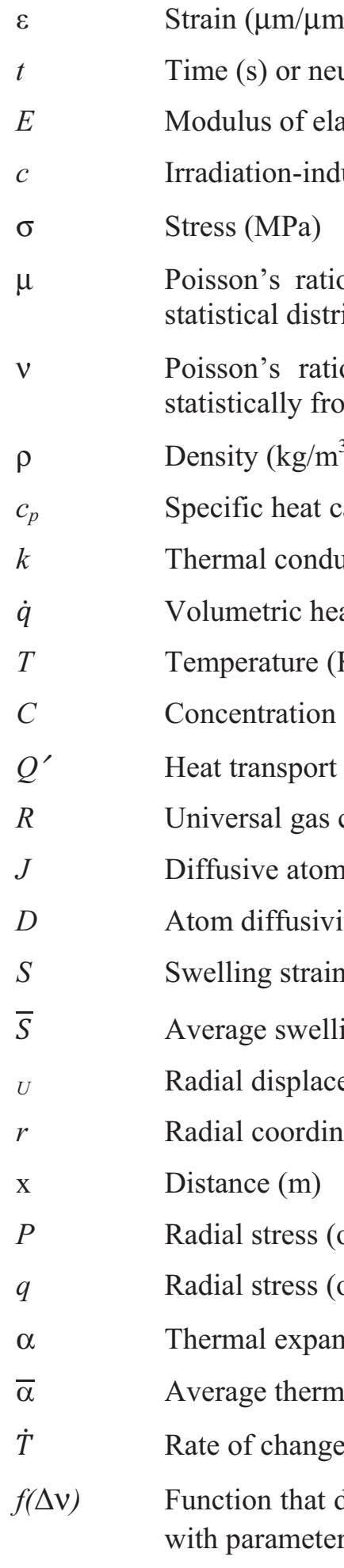

$u$

$r$

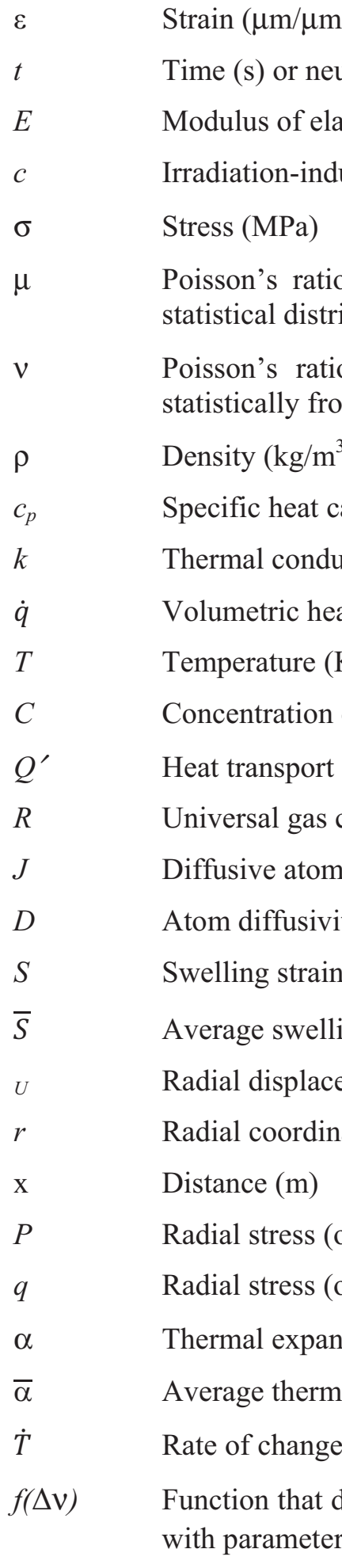

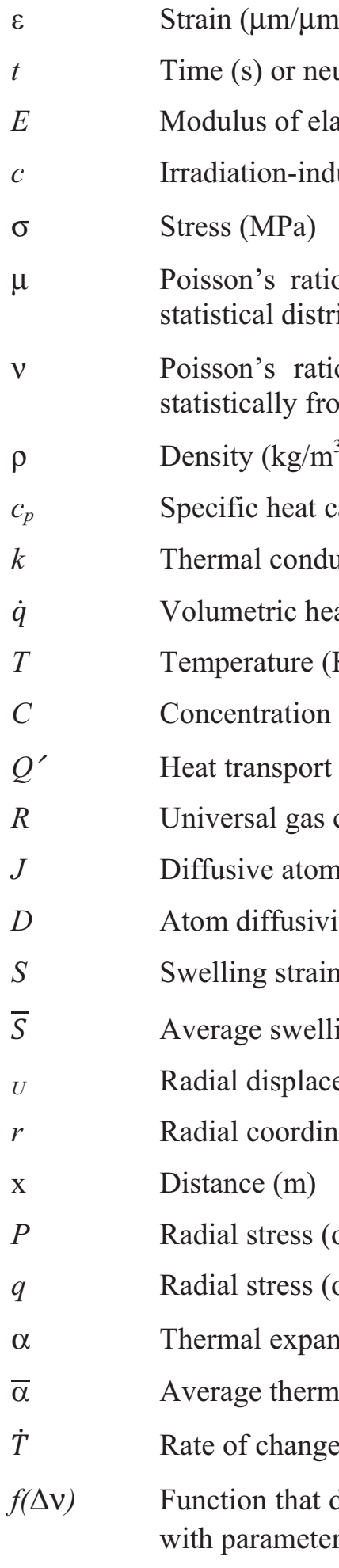

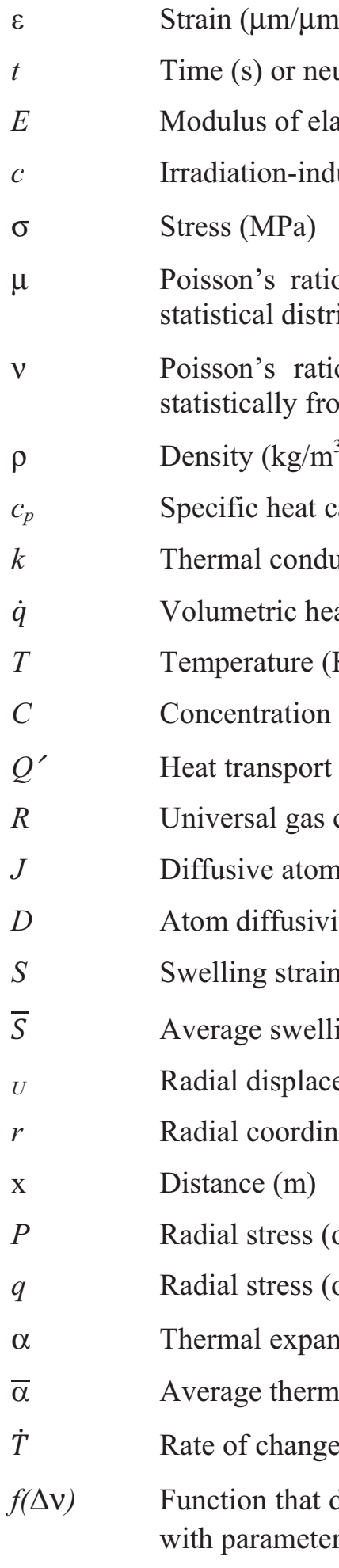

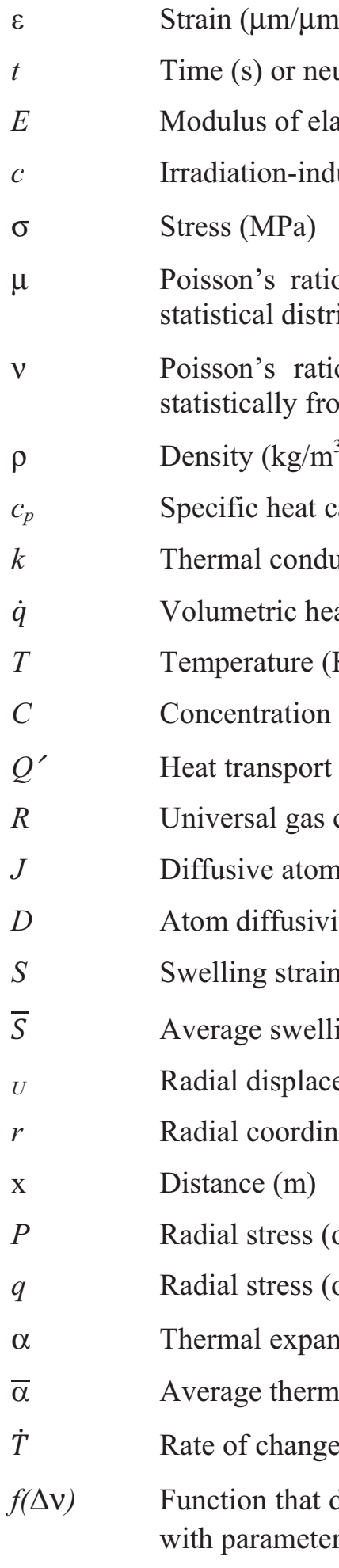

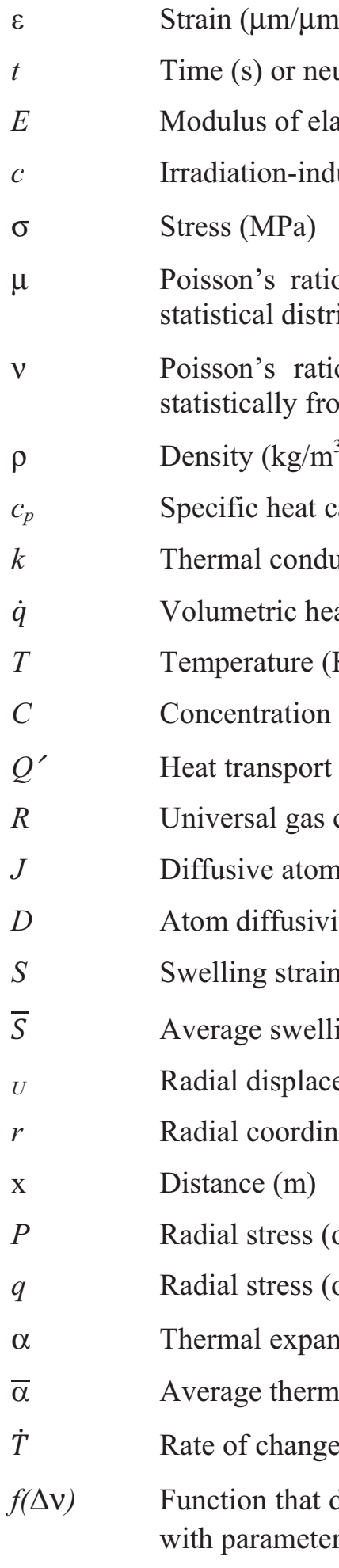

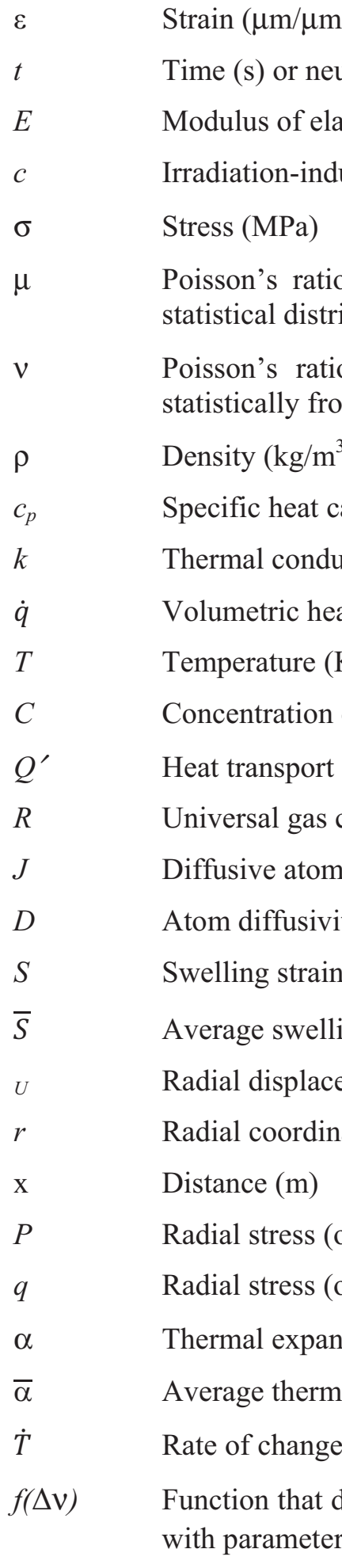

$g(\Delta v) \quad$ Function that describes the variation of maximum stress in the SiC layer of an uncracked particle with parameter $\mathrm{V}$

$h(\Delta v) \quad$ Ratio $f(\Delta v) / g(\Delta v)$ 
I Normalized integration of the stress distribution over the volume of a coating layer $\left(\mathrm{m}^{3}\right)$

$m \quad$ Weibull modulus for a coating layer

$P_{f} \quad$ Probability of failure for a coating layer

$V \quad$ Volume of a coating layer $\left(\mathrm{m}^{3}\right)$

$\sigma \quad$ Stress in a coating layer (MPa)

$\sigma_{c} \quad$ Maximum principal stress in the volume of a coating layer (MPa)

$\sigma_{u} \quad$ Stress in a coating layer for a normal spherical particle (MPa)

$\sigma_{c \bar{v}} \quad$ Stress in the $\mathrm{SiC}$ layer for a multidimensional particle having all parameters set at mean values for a particle batch $(\mathrm{MPa})$

$\sigma_{u \bar{v}} \quad$ Stress in the $\mathrm{SiC}$ layer for an intact spherical particle having all parameters set at mean values for a particle batch (MPa)

$\sigma_{o} \quad$ Weibull characteristic strength for a coating layer $\left(\mathrm{MPa}-\mathrm{m}^{3 / \mathrm{m}}\right)$

$\sigma_{m s} \quad$ Effective Weibull mean strength for a coating layer (MPa)

$\sigma_{i} \quad \mathrm{i}=1,2,3$, Principal stress components in three orthogonal directions (MPa)

$\Delta v \quad$ Variation in parameter $v$ from its mean value

$\lambda \quad$ Strength for a coating layer in a random particle as sampled from a Gaussian distribution (MPa)

$\lambda_{\mathrm{s}} \quad$ Mean strength for a coating layer having a Gaussian strength distribution (MPa)

$\theta \quad$ Latitude angle (radians)

$\phi \quad$ Azimuth angle (radians)

Subscripts

$r \quad$ radial

$t \quad$ tangential

I IPyC layer

$S \quad$ SiC layer

O OPyC layer

a inner surface of a coating layer

$b \quad$ outer surface of a coating layer

$B$ buffer

k kernel 


\section{PARFUME User's Guide}

\section{INTRODUCTION}

PARFUME, the "PARticle FUel ModEl," is being developed as an advanced gas-cooled reactor fuel performance modeling and analysis code. This guide provides information for PARFUME Version 2.19 users, including: (1) background information, (2) capabilities and limitations, (3) installation and execution, (4) user input and output, (5) error messages, and (6) a sample problem. This document represents the initial version of the PARFUME User's Guide. The PARFUME Theory and Model Basis Report ${ }^{1}$ describes the theoretical aspects of the code.

\subsection{Background}

\subsubsection{Historical Development}

Initial development of the coated fuel particle and its inventor, Roy Huddle, can be traced back to the Organization for Economic Cooperation and Development's (OECD's) Dragon high-temperature experimental reactor, which operated successfully from 1964 to 1975 . $^{2}$ Since then, several countries have constructed gas reactors using coated fuel particles. The coated particles, composed of either pyrolytic carbon (PyC) alone (bistructural isotropic, or BISO) with two coated layers, or silicon carbide (SiC) and PyC (tri-structual isotropic, or TRISO) consisting of three coated layers, were manufactured using high-temperature chemical vapor deposition in a fluidized bed. Dragon was the first reactor to use TRISO particles, while Peach Bottom (Unit 1), a commercial power gas reactor built by the United States, was fueled with cylindrical fuel elements containing BISO particles. Eventually, the U.S. and the international community focused research efforts on TRISO fuel particles, primarily due to their performance history and reliability.

Idaho National Laboratory (INL) began development of gas reactor fuel performance codes in the early 1990s with the release of the FUEL computer code. In early 2000, the Generation IV International Forum identified several reactor technology concepts for future generation nuclear energy systems; included in the technology concepts were advanced gas reactors such as the Very High Temperature Reactor (VHTR). Consequently, a need for state-of-the-art gas reactor fuel performance codes was re-established, and development of PARFUME, the successor to the FUEL code, began.

\subsubsection{Fuel Performance Codes}

Over the years, several fuel performance analysis tools (i.e., codes), including "pellet fuel rod codes" and "fuel particle codes," have been developed. A few of the "single fuel rod" codes (i.e., non-particle) include: FRAPCON, a 1D code originally developed as a combined effort of INL and Pacific Northwest National Laboratory (PNNL), who currently oversees the development of this code; Fuel Performance Analysis Capability (FALCON), a propriety 2D code developed by the Electric Power Research Institute (EPRI); and TOUTATIS and ALCYONE, both 3D French codes being developed under the PLEIADES software environment. ${ }^{3}$

Prominent fuel-particle analysis codes that are in use today or are under development include: STRESS3 (UK), PANAMA (Forschungszentrum Juelich [FZJ], Germany), ATLAS (Commissariat à l'Energie Atomique [CEA], France), TIMCOAT (Massachusetts Institute of Technology [MIT], U.S.), COPA (Korea), PARFUME (INL, U.S.), and a fuel performance code developed by the Japan Atomic Energy Research Institute (JAERI). ${ }^{4,5}$ Although most of the fuel particle codes have unique capabilities and limitations, PARFUME is recognized for its computational efficiency, closed-form stress/displacement analytical solution method, and dual-solution scheme (i.e., Monte Carlo and numerical integration) for computing failure probability. 


\subsubsection{Fuel Particle Description}

The coating layers of a TRISO fuel particle, which surround the fuel kernel and buffer, consist of an inner pyrolytic carbon (IPyC) layer, a $\mathrm{SiC}$ layer, and an outer pyrocarbon (OPyC) layer. The fuel kernel is typically comprised of uranium dioxide $\left(\mathrm{UO}_{2}\right)$, although uranium oxycarbide (UCO) is under development in the United States. ${ }^{6}$ Fuel particle diameters are on the order of $0.9 \mathrm{~mm}$. A typical TRISO-coated particle is shown in Figures 1-1 and 1-2.

Coated particle fuel exhibits statistical variations in physical dimensions and material properties from particle to particle due to the nature of its fabrication process. ${ }^{7}$ Its behavior is also inherently multidimensional, further complicating fuel particle analysis. The objective in developing PARFUME is to physically describe both the mechanical and physico-chemical behavior of the fuel particle under irradiation, while capturing the statistical nature of the fuel.

Several mechanisms have been identified that can potentially lead to particle failure, including cracking of the IPyC during irradiation, debonding of the IPyC from the SiC layer during irradiation, buildup of internal fission gas pressure, kernel/SiC interaction resulting from the amoeba effect, and thinning of the $\mathrm{SiC}$ layer due to fission-product/SiC interactions. The details of these phenomena and related models are explained in References 1 and 8.

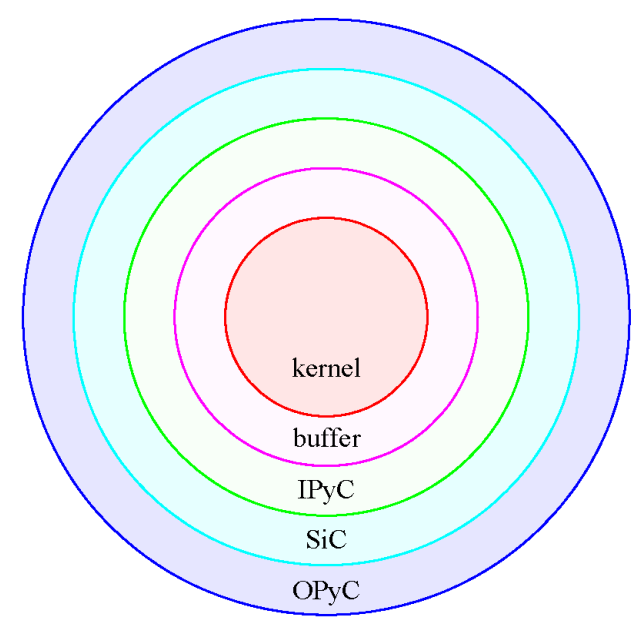

Figure 1-1. Typical TRISO-coated fuel particle geometry.

\subsubsection{Basic Fuel Particle Behavior}

As fuel particles undergo irradiation and temperature changes, fission gas pressure builds up in the kernel and buffer regions, while the $\mathrm{IPyC}, \mathrm{SiC}$, and $\mathrm{OPyC}$ act as structural layers to retain this pressure and act as a barrier to the migration of fission products (FPs). The irradiation effect on the fuel particles is shown in Figure 1-2, which shows two different particles before and after irradiation. Several phenomena result in changes to the fuel particle. The IPyC and OPyC layers both shrink and creep due to irradiation of the particle, while the $\mathrm{SiC}$ response is essentially limited to elastic behavior. The pressure generally increases as irradiation of the particle progresses, thereby contributing to a tensile hoop stress in the $\mathrm{SiC}$ layer. Failure of the particle is expected to occur if the stress in the $\mathrm{SiC}$ layer reaches the fracture strength of the $\mathrm{SiC}$. Failure of the $\mathrm{SiC}$ results in an instantaneous release of elastic energy that should be sufficient to cause simultaneous failure of the PyC layers. 

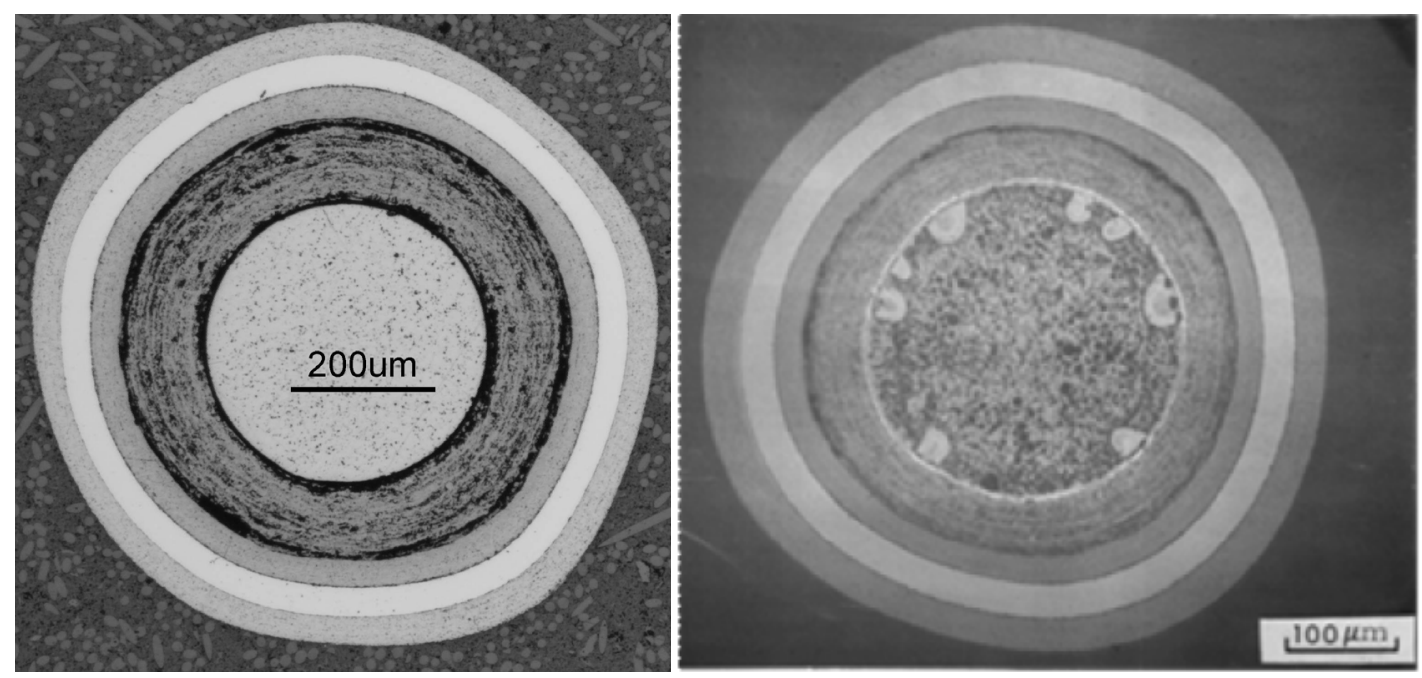

Figure 1-2. Particles before and after irradiation.

The shrinkage/swelling response of $\mathrm{PyC}$ is highly anisotropic and depends on the irradiation temperature and degree of anisotropy of the PyC. Studies have shown that as the irradiation temperature increases, the shrinkage increases and the stress in the IPyC increases. Offsetting the shrinkage effect is irradiation-induced creep of the PyC. Examples of shrinkage/swelling strains and creep coefficients, used to model secondary creep, for UCO particles are depicted in Figures 1-3 and 1-4.

\subsubsection{Material Properties}

Material properties used in PARFUME to represent the shrinkage, creep, thermal expansion, and elastic behavior of the coating layers were obtained from a report prepared by the CEGA Corporation in July $1993 .{ }^{9}$ Due to uncertainties or incompleteness in the material data, several assumptions and approximations were required to develop the material properties.

\subsubsection{Known Failure Mechanisms}

Through years of fuel development and qualification programs, a number of potential fuel failure and fission-product-release mechanisms have been identified. ${ }^{6}$ These failure mechanisms have been determined to be temperature and burn-up dependent. The mechanisms are categorized into three major failure modes: pressure vessel failure, $\mathrm{SiC}$ degradation, and multi-dimensional failure. Brief descriptions of the phenomena associated with each mode are presented below.

\subsubsection{Pressure Vessel Failure Mode}

A traditional failure mechanism addressed in PARFUME as well as other fuel performance codes is the pressure vessel failure of a one-dimensional spherical particle. The particle is one-dimensional because of perfect symmetry in the tangential and azimuthal directions. Early during irradiation, the shrinkage of the PyC layers puts the SiC layer in compression. As irradiation progresses, the irradiation-induced creep of the PyC layers tends to relieve some of this compressive stress. Additionally, the buildup of fission gas pressure tends to put the coating layers in tension. If the gas pressure increases enough, the tangential stress in the $\mathrm{SiC}$ layer could eventually become tensile. A traditional pressure vessel failure is expected to occur if the tangential stress reaches a value that exceeds the strength of the $\mathrm{SiC}$ for that particle. 


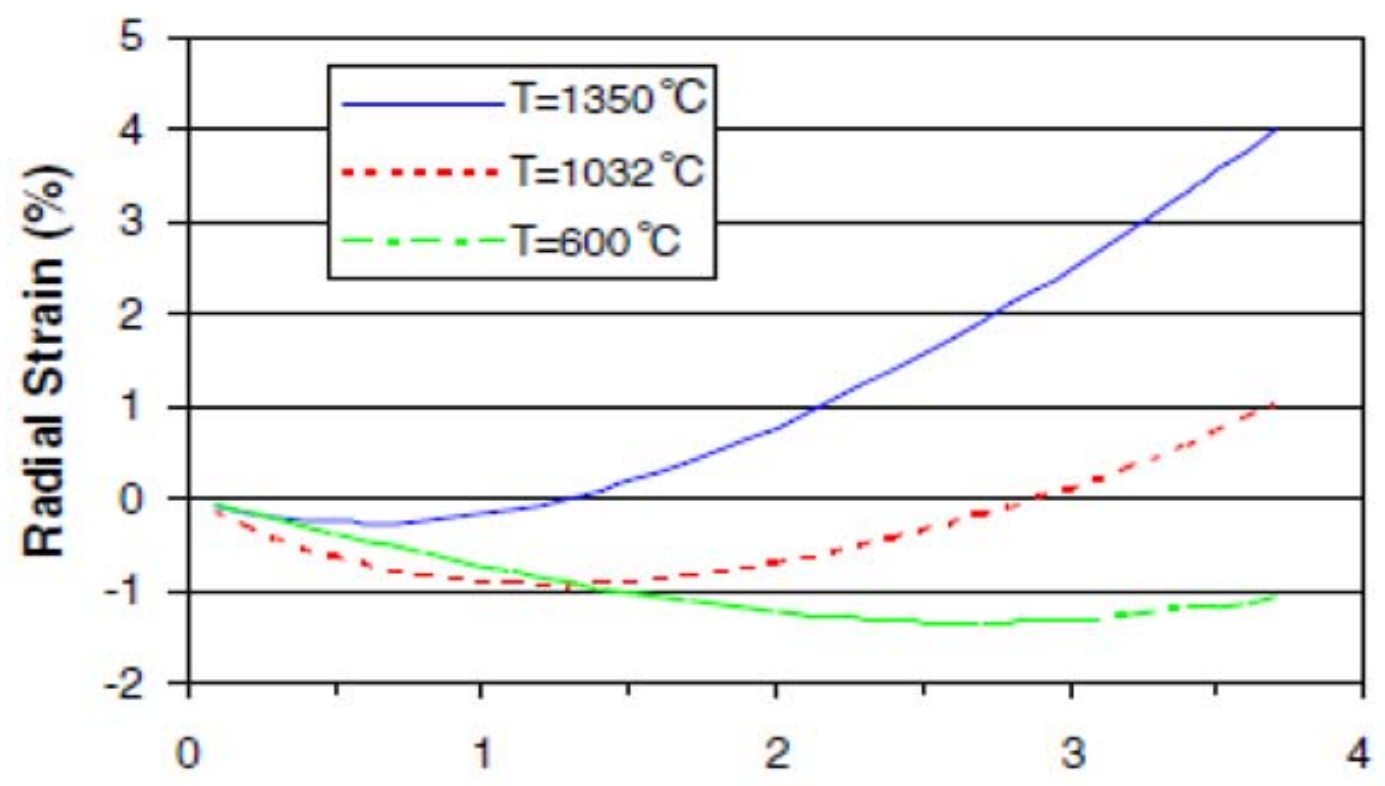

Fast Neutron Fluence $\left(10^{25} \mathrm{n} / \mathrm{m}^{2}, \mathrm{E}>0.18 \mathrm{MeV}\right)$

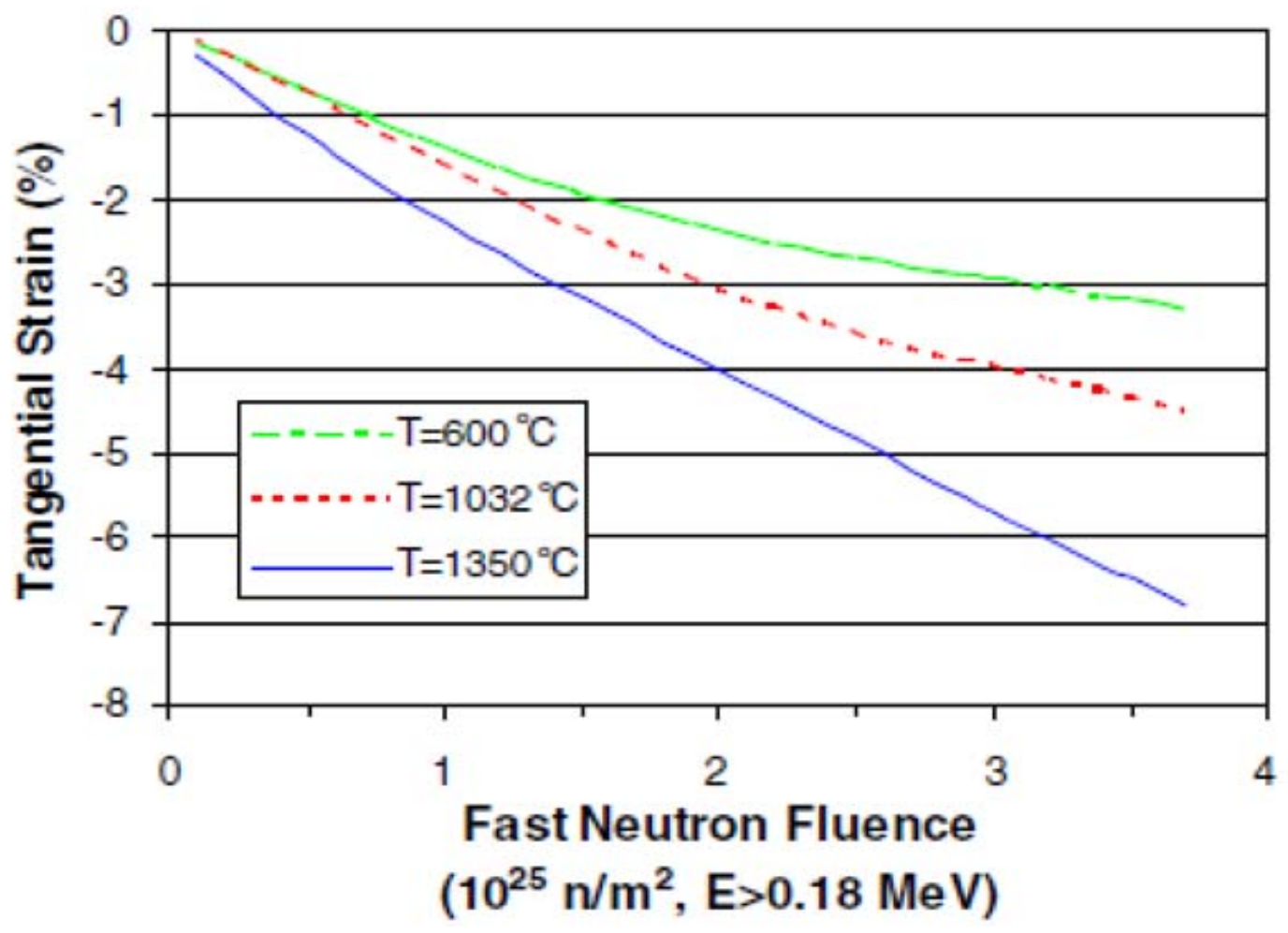

Figure 1-3. Radial and tangential irradiation-induced strains in PyC. 


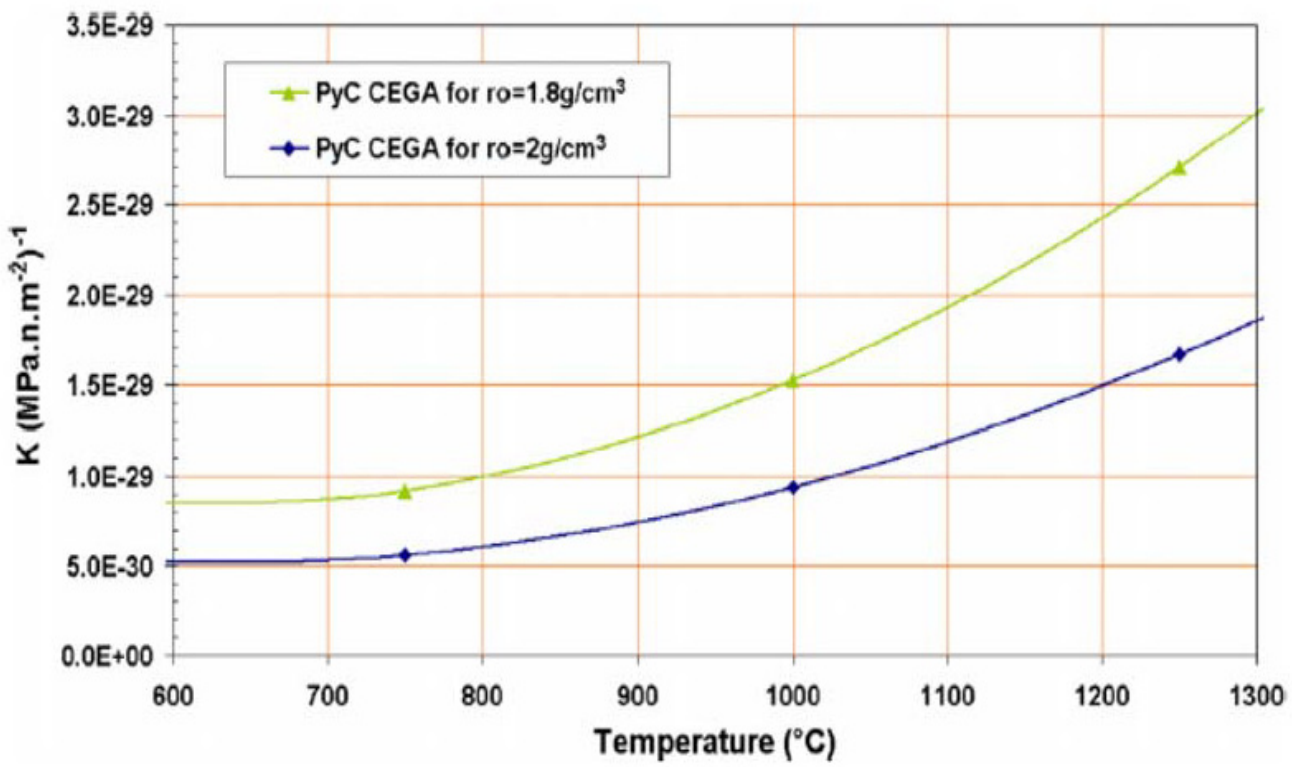

Figure 1-4. Irradiation-induced creep constant for PyC.

\section{Fission Gas Pressure}

Fission gases released during irradiation from the kernel of a coated particle depend on temperature, burnup, and time. Table 1-1 presents the normalized fission gas pressure that builds up in a $500-\mu \mathrm{m}$ (kernel diameter) German $\mathrm{UO}_{2}$ particle irradiated for three years at the indicated temperature and burnup. The results indicated a factor-of-eight increase in pressure as the burnup increased from 8 to 20\% FIMA and the temperature increases from 1100 to $1300^{\circ} \mathrm{C}$.

\section{CO Gas Pressure}

Oxygen is released during the fission process. In $\mathrm{UO}_{2}$ coated particle fuels, there is net excess or "free" oxygen because the fission products (FPs) that are produced do not consume all of the oxygen released. The excess oxygen reacts with the buffer to form $\mathrm{CO}$ gas. The amount of $\mathrm{CO}$ produced is a function of temperature and burnup. Depending on operating conditions and fuel design, the CO contribution to total internal pressure can be as high as four times the contribution from FP gases.

Table 1-1. Comparison of fission gas pressures in a German particle.

\begin{tabular}{cccccc}
\hline \multicolumn{6}{c}{ Temperature ${ }^{\circ} \mathrm{C}$} \\
Burnup (\% FIMA) & 1100 & 1150 & 1200 & 1250 & 1300 \\
\hline 8 & 1.00 & 1.28 & 1.62 & 2.04 & 2.52 \\
10 & 1.33 & 1.69 & 2.14 & 2.68 & 3.28 \\
15 & 2.26 & 2.86 & 3.60 & 4.47 & 5.42 \\
20 & 3.32 & 4.21 & 5.28 & 6.53 & 7.89 \\
\hline (Normalized to 1.0 at $8 \%$ FIMA and $1100^{\circ} \mathrm{C}$ ) & & & \\
\hline
\end{tabular}




\subsubsection{SiC Degradation Mode}

In addition to manufacturing defects, several phenomena are known to degrade the $\mathrm{SiC}$ layer. Thermal decomposition and localized attack of the $\mathrm{SiC}$ are known to occur under certain conditions. Specifically, palladium, cesium, and carbon monoxide (CO) are known to attack the SiC, while thermal decomposition of the $\mathrm{SiC}$ layer is known to occur at elevated temperatures. Currently, PARFUME does not model the thermal decomposition or localized attack of SiC.

\section{Initially Defective SiC Layer}

During manufacture, a small percentage of fuel particles will have a defective SiC layer. A model is planned to be included in PARFUME to predict the diffusion of FPs through the initially defective SiC layers.

\section{Palladium Attack}

Palladium $(\mathrm{Pd})$ is known to attack $\mathrm{SiC}$ at localized reaction sites. This interaction has been the subject of extensive study. Depending on the fuel type, Pd attack of the $\mathrm{SiC}$ could be higher in fuels designed to operate under high-temperature conditions.

\section{Cesium Attack}

Increased cesium (Cs) release is known to occur at high burnups. The reason for the elevated release is not certainty, but some researchers have attributed the release to degradation of the $\mathrm{SiC}$ layer by cesium as well as other FPs.

\section{Carbon Monoxide Attack}

The excess oxygen produced during the fission process that forms $\mathrm{CO}$ can attack SiC.

\subsubsection{Multi-dimensional Failure Mode}

In addition to the phenomena described above, PARFUME also considers multi-dimensional behavior that has been observed in post-irradiation examination (PIE) of U.S. fuel particles that may contribute to particle failures, such as (1) cracking of the IPyC layer, (2) partial debonding of the IPyC from the SiC layer, (3) an aspherical geometry, and (4) the amoeba effect. Each failure phenomena is described below.

\section{Cracking of the IPyC}

One form of multi-dimensional behavior modeled in PARFUME is a radial shrinkage crack in the IPyC. During irradiation, shrinkage of the initially intact IPyC layer induces a significant tensile stress in that layer. If the stress exceeds the tensile strength of the IPyC layer, a radial crack develops in the IPyC. The radial crack creates local tensile stresses in the $\mathrm{SiC}$ layer that could lead to particle failure. The stress at this point increases as the $\mathrm{PyC}$ layers shrink during irradiation but eventually peaks as creep in the PyC layers overcomes the shrinkage effect.

\section{Partial Debonding of the IPyC from the SiC}

A second form of multi-dimensional behavior modeled in PARFUME is partial debonding between the IPyC and the SiC. During irradiation, shrinkage of the IPyC layer induces a radial tensile stress at the interface between the IPyC and $\mathrm{SiC}$ layers. If the stress exceeds the bond strength between layers, then debonding of the IPyC from the $\mathrm{SiC}$ occurs. The debonding process is not likely to be an instantaneous 
detachment over the entire surface of the interface. Rather, it begins at an initiation point from which the layers progressively unzip during irradiation.

\section{Particle Asphericity}

A third form of multi-dimensional behavior modeled in PARFUME is asphericity. During irradiation, the faceted portion of the particle acts as a flat plate that retains the internal gas pressure. If the pressure builds up high enough, this results in a local region of tensile stress in the central portion of the plate, which can contribute to particle failures. Unlike failures caused by cracking of the IPyC or partial debonding of the IPyC, which are governed by shrinkage of the pyrocarbons, failures caused by asphericity are controlled by the internal pressure. Therefore, while failures due to IPyC cracking and debonding tend to occur early during irradiation when shrinkage stresses are at their highest, failures due to asphericity are likely to occur later when the internal pressure is highest. The Code incorporates the effects of asphericity for particles that have a flat facet but that are otherwise spherical. Because the effects of an ellipsoidal shape are small in comparison, this type of asphericity is not included in the Code.

\section{Amoeba Effect}

A final multi-dimensional failure mechanism currently considered in the code is failure of the $\mathrm{SiC}$ due to the amoeba effect. Kernel migration is the tendency for the fuel kernel to migrate up the temperature gradient. It has been observed in all $\mathrm{UO}_{2}$ TRISO-coated fuel particles, and it does not involve stress levels in the coating layer. Failure due to the amoeba effect is evaluated by determining the distance that the fuel kernel migrates as a function of the temperature gradient at the particle location. Particle failure is assumed to occur when the kernel comes into contact with the SiC layer. Studies have shown that as the fuel temperature increases from 100 to $1300^{\circ} \mathrm{C}$, the propensity for kernel migration increases by a factor of 1.7. Figure 1-5 shows an example of a fuel particle where the kernel has migrated towards the IPyC.

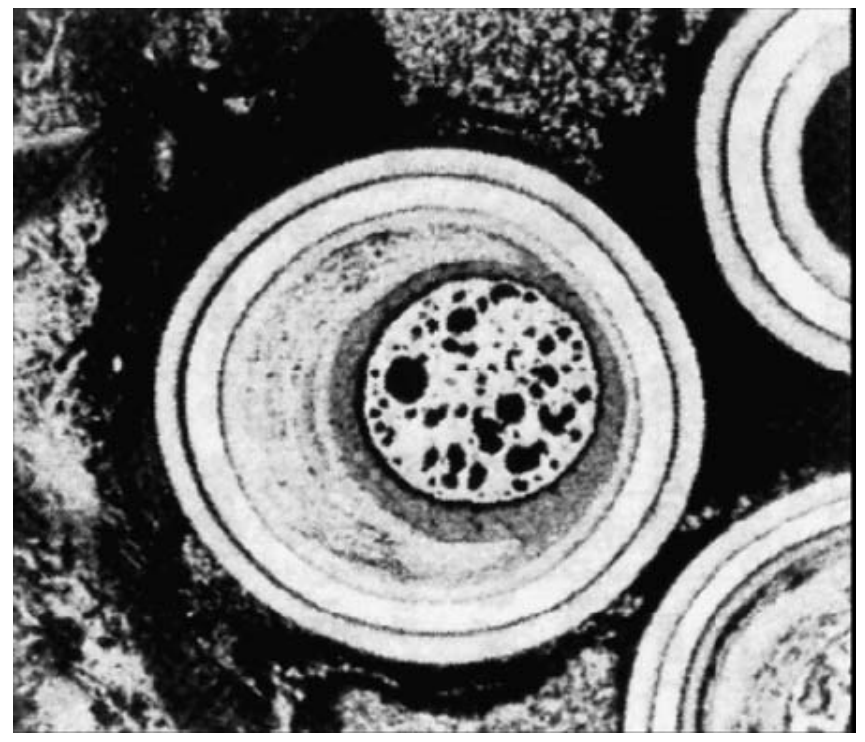

Figure 1-5. Example of kernel migration. 


\subsubsection{Potential Design Solutions}

In an effort to prevent fuel particle failure by the mechanisms described above, several design changes have been considered-for example, reducing the kernel size, using $\mathrm{UCO}$ instead of $\mathrm{UO}_{2}$ for the kernel, using a special type of $\mathrm{UO}_{2}$ in which a $\mathrm{ZrC}$ layer is applied directly to the kernel, or replacing $\mathrm{SiC}$ with $\mathrm{ZrC}$. The basis for these design solutions is presented in Reference 6. Additionally, replacement of $\mathrm{SiC}$ with $\mathrm{ZrC}$ has been implemented in PARFUME and is available as an option in the input data deck. 


\section{CAPABILITIES and LIMITATIONS}

This section presents a summary of the capabilities and limitations of PARFUME. A review of the geometric and physical models used is presented to familiarize the user with the terminology associated with the fuel particle code and fuel particle terminology in general.

PARFUME is an integrated mechanistic analysis tool that evaluates the thermal, mechanical, and physico-chemical behavior of TRISO-coated fuel particles and the probability for fuel failure given the particle-to-particle statistical variations in physical dimensions and material properties that arise during the fuel fabrication process. Using a robust finite difference numerical scheme, PARFUME is capable of analyzing steady-state and transient fuel behavior. Written in FORTRAN 77, PARFUME compiles in FORTRAN 90, and it is easy to read, maintain, and modify. Currently, PARFUME is supported only on Linux platforms.

PARFUME is capable of analyzing particle behavior during reactor operations and subsequent heating/cooling operations, but the front-end post manufacturing heating/cooling operations prior to reactor operations cannot be analyzed by the code. A typical problem that PARFUME can analyze is presented in Section 6.

\subsection{Code Description}

\subsubsection{Model Development}

Model development and integration within PARFUME is a relatively complex process; therefore, the interested reader is directed to the PARFUME Theory and Model Basis Report for the theoretical details related to physical models and methods. Nevertheless, users should have a fundamental understanding of not only the theory associated with the development of PARFUME, but a good understanding of the general solution process as well. Figure 2-4 provides an overview of the solution procedure; additional details are presented below.

\subsubsection{General Solution Procedure}

The general solution procedure used by PARFUME consists of the 5-step processes depicted in the flow chart of Figure 2-4. A general description of each step in the process is given below, while a detailed description of each process is provided in Reference 1.

\subsubsection{Geometry Specification (Step 1)}

This step of the process includes pre-processing steps including: geometry, mesh, and material property selection.

\section{Geometry}

The basic fuel particle geometry, described in Section 1.1.2, consists of a kernel of $\mathrm{UO}_{2}$ or UCO surrounded by a buffer and three structural layers (IPyC, SiC, OPyC). The particles are embedded in a spherical, cylindrical, or plate-type graphite matrix; collectively, the fuel particles and matrix are referred to as a fuel element. Note that particles embedded in a spherical graphite matrix are called "pebbles"; each pebble contains several thousand coated fuel particles depending upon the fuel design. For example, each pebble for the PBMR-400 design contains approximately 15,000 fuel particles. 
Within PARFUME, three fuel-element geometries (i.e., plane, spherical, and cylindrical) may be simulated in one dimension, as presented in Figure 2-1. Each geometry is modeled by averaging spherical fuel particles, void regions (i.e., coolant channels), and the graphite matrix. This modeling technique is necessary in order to capture the physical behavior of the fuel elements while eliminating the complexities (e.g., computational requirements) of modeling the detailed composition of the fuel element-for example, 15,000 coated fuel particles.

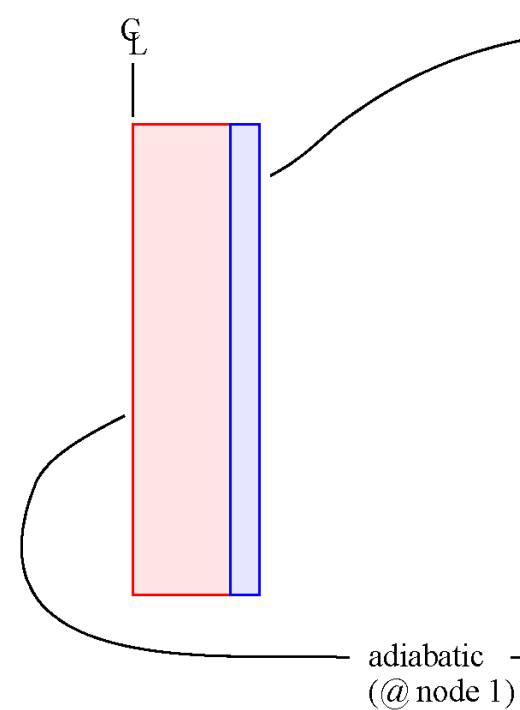

(a) Plane Geometry surface temperature

or

convective boundary

(@) other boundary node)
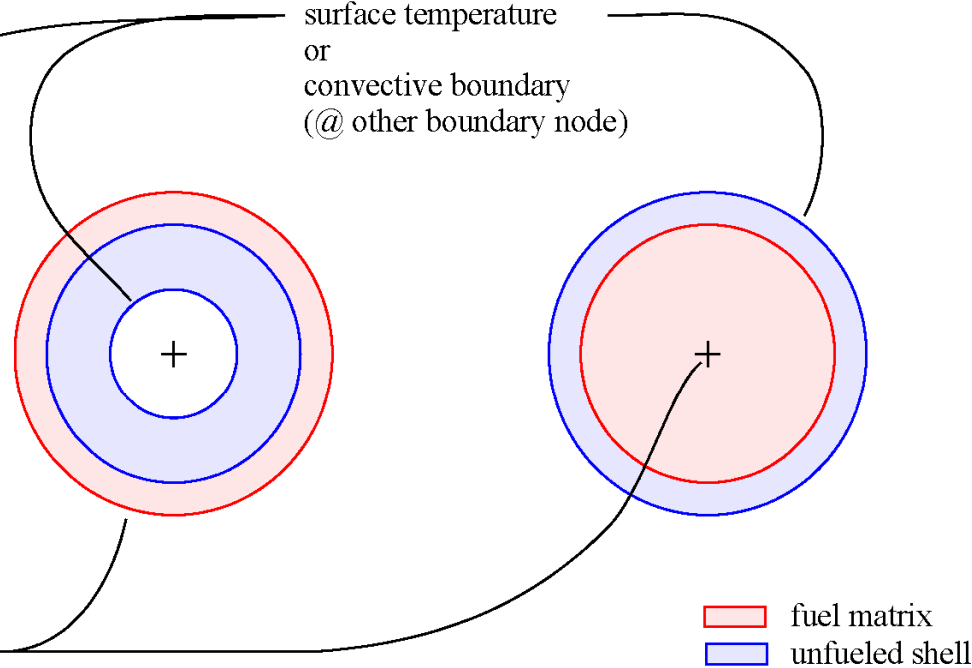

unfueled shell
(@) node 1)

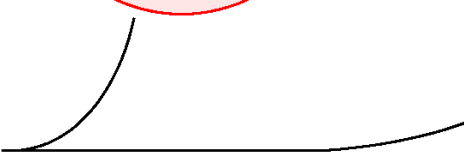

(b) Prismatic Geometry (c) Spherical Geometry

Figure 2-1. PARFUME fuel-element geometries.

A plane geometry option is provided to allow simulation of plate-type fuel. It is assumed that the plate will consist of a center-fueled region bounded on both sides by a non-fueled region. The centerline of the plate therefore represents a line of symmetry for both heat and mass transfer. Although plate-type fuel has become unpopular over the years, some reactors, such as the Advanced Test Reactor, continue to use plate-type fuel, so the plane geometry option is included in PARFUME for completeness.

A spherical geometry option is provided to allow simulation of a single pebble from a pebble bed reactor. The center of the sphere represents a line of symmetry relative to heat and mass transfer. An unfueled region, the graphite layer, representing the on the outer edge of the sphere, communicates with the fueled region on one edge and the coolant on the remaining edge.

A cylindrical geometry option is provided to allow simulation of a unit cell from a prismatic reactor core. As an approximation, an appropriate fraction of six fuel compacts represents an equivalent fueled region in the form of a ring. The outer edge of that ring is symmetric relative to both heat and mass transfer. An unfueled region representing the matrix graphite communicates with the fueled region on one edge and the coolant channel on the remaining edge. Figure 2-2 depicts the basic geometry used to develop the cylindrical fuel element geometry. 


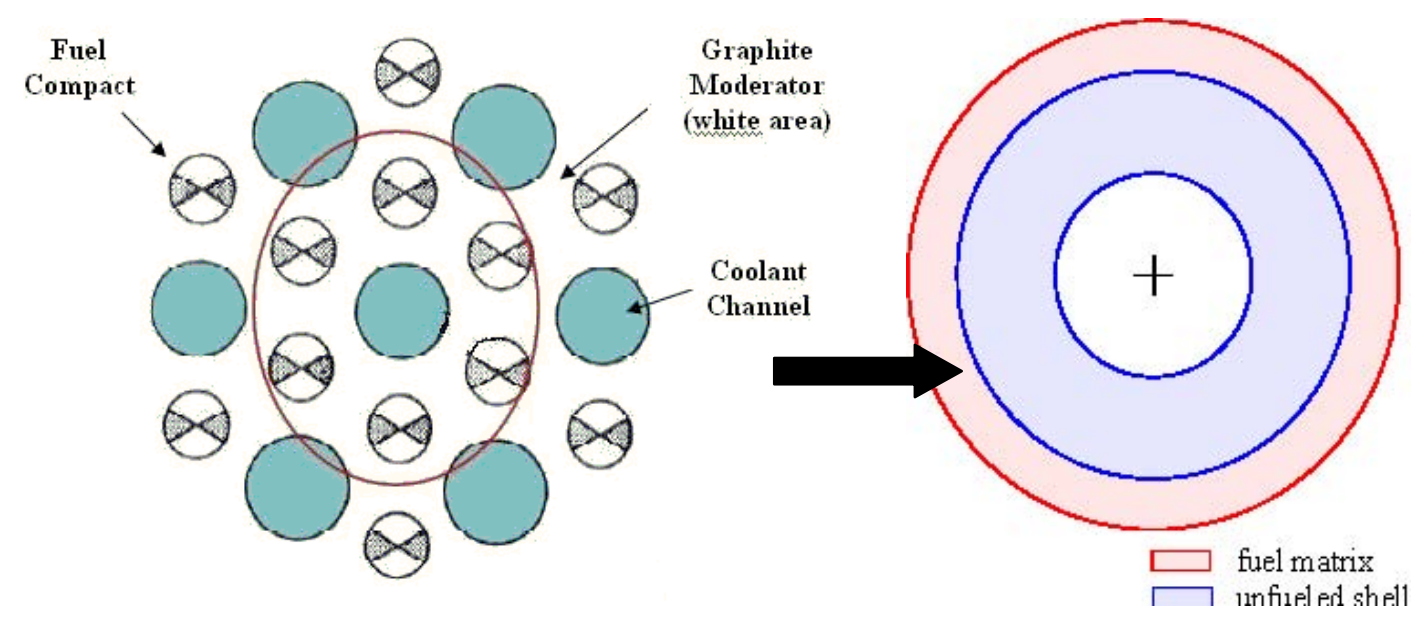

Figure 2-2. Prismatic fuel element geometry.

\section{Mesh}

PARFUME requires generation of two 1-D meshes: the "fuel particle" mesh and the "fuel element" mesh. Examples of fuel particle mesh and fuel element mesh are presented in Figure 2-3. With respect to the fuel particle mesh, the user does not specify the number of nodes, but by default, the code places nodes at $5 \mu \mathrm{m}$ increments and on the outer surface of each layer. By default, nodes (i.e., ko, bo, io, so, oo) are placed at the interface of the geometry. However, the thickness of buffer and structural layers is small relative to the kernel, which implies that minimal differences in parameters (i.e., temperature) within a layer exist.

For the fuel element mesh, the user specifies the number of nodes. Referring to Figure 2-1, a line of symmetry relative to both heat and mass transfer exists in each geometry. Node 1 is always placed on that line of symmetry. Each geometry is then divided into intervals consistent with the number of nodes specified by the user. The last node always aligns with a boundary that may have either a surface temperature specification or a convective surface specification. 


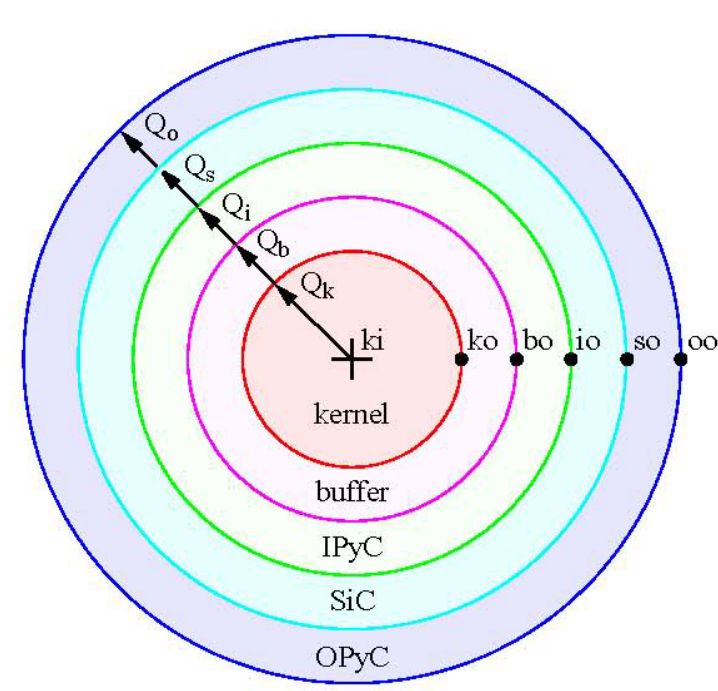

a. Fuel Particle

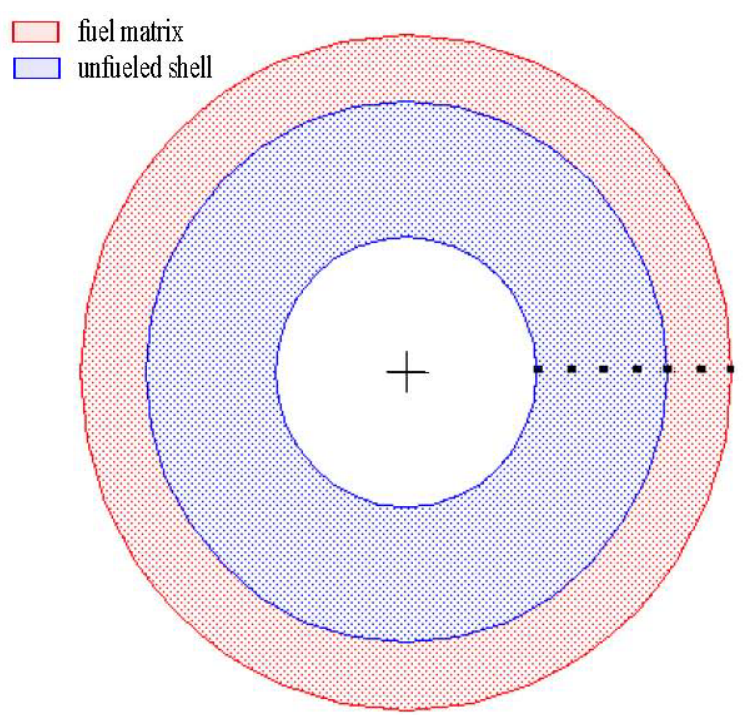

b. Fuel Element

Figure 2-3. Fuel particle and fuel element mesh.

\section{Material Properties}

Material properties, both structural and thermal, in the form of models used in PARFUME to represent the shrinkage, creep, thermal expansion, and elastic behavior of the coating layers, were obtained from a report prepared by the CEGA Corporation in July $1993^{9}$. The range of validity of these properties forms the basis for the overall analysis limitations of PARFUME. For example:

- In general, application of the material models is limited to the range of $4 \times 10^{25} \mathrm{n} / \mathrm{m} 2, \mathrm{E}>0.18 \mathrm{MeV}$ for fast neutron fluence and 600 to $1300^{\circ} \mathrm{C}$ for irradiation temperature.

- The densities of the dense structural PyC and the porous PyC are limited to 1.8 to $2.0 \mathrm{Mg} / \mathrm{m}^{3}$ and approximately 0.9 to $1.1 \mathrm{Mg} / \mathrm{m}^{3}$, respectively; the density of $\mathrm{SiC}$ is at least $3.18 \mathrm{Mg} / \mathrm{m}^{3}$.

- Due to the scarcity of material data, it is assumed in the material models that the effects of several parameters (i.e., temperature, fluence, density) are mutually independent and their combined effect can be obtained by multiplying them together.

- Irradiation-induced creep in the PyC layers is treated as secondary creep, i.e., the creep strain rate is proportional to the level of stress in the PyC. The creep coefficient increases significantly with increases in the irradiation temperature.

- Thermal expansion of the PyCs is anisotropic and is a function of the anisotropy as represented by the Bacon Anisotropy Factor (BAF) and temperature.

- Swelling in the PyC layers is anisotropic and a function of four variables: fluence level, PyC density, degree of anisotropy (as measured by BAF), and irradiation temperature. The magnitude of the shrinkage increases as BAF increases or as the irradiation temperature increases.

- The SiC layer has an elastic modulus (stiffness) that is an order of magnitude higher than that for the PyCs.

- The dependence of Poisson ratio, v, (for the PyC layers) on density, crystallite size, temperature and fluence is largely unknown; therefore, it is assumed that Poisson's ratio is independent of these parameters. 
- Most available mechanical property test data for PyC correspond to densities of $1.5 \mathrm{Mg} / \mathrm{m}^{3}$ or higher. For the buffer layer (porous PyC), which has a density of approximately $1.0 \mathrm{Mg} / \mathrm{m}^{3}$, a large extrapolation of the data is required, which may significantly affect its accuracy.

Additional details, related to mechanical properties, are presented in Reference 1.

\subsubsection{Compute Fuel Element Temperature Profile (Step 2)}

Once the fuel element geometry and temperature boundary conditions are identified, the general heat conduction equation, represented by Equation (2-1), is used to compute the macro temperature distribution throughout the fuel element. The volumetric heat generation rate consists of the total heat generation rate of all the particles due to fission. Energy generation due to radioactive decay of other nuclides is not modeled.

$\rho c_{p} \frac{\partial T}{\partial t}=k \bullet \nabla^{2} T+\dot{q}$

\subsubsection{Compute Fuel Particle Temperature Profile (Step 2)}

Once the macro temperatures for the fuel element are determined, the general heat conduction equation is used to compute the micro temperature profile (using a quasi-steady-state assumption). Specifically, the term on the left-hand side of Equation (2-1) (time rate of change of temperature) is assumed to be zero, resulting in Poisson's equation. Therefore, two boundary conditions are required, i.e., the surface temperature of the particle surface and the spatial temperature gradient at the geometric line of symmetry. The particle surface temperature is obtained from the "macro" temperature distribution computed from Equation (2-1), while the spatial temperature gradient at the line of symmetry is set equal to zero. The micro temperature profile accounts for all deformations in the kernel, buffer, and coating layers of the particle as well as the potential for development of a gap between the buffer and the IPyC.

\subsubsection{Compute Particle Stress Distribution (Step 3)}

Once a particle temperature profile is determined, the particle stress distribution is calculated to evaluate whether or not the particle fails. Currently, stress and displacement distribution calculations are limited to the buffer, IPyC, SiC, and OPyC, though the effect of kernel swelling is included. Strain contributions from several sources are included. Note that PARFUME does not perform stress analyses of the fuel element matrix material.

The system of equations used to compute the stress distribution in a spherical particle includes constitutive relationships (describing elastic, irradiation-induced, and thermal strain), strain-displacement equations, and the equilibrium stress equation. The two component strain equations (i.e., constitutive relationships) take into account elastic, irradiation-induced creep, irradiation-induced swelling, and thermal strain. The radial strain-rate equation, consisting of four strain terms, is shown in Equation (2-2). Note that the pressure contribution to strain due to fission gases and $\mathrm{CO}$ is accounted for in the displacement and stress relationships presented in Reference 1.

$\frac{\partial \varepsilon_{r}}{\partial t}=\frac{1}{E}\left(\frac{\partial \sigma_{r}}{\partial t}-2 \mu \frac{\partial \sigma_{t}}{\partial t}\right)+c\left(\sigma_{r}-2 v \sigma_{t}\right)+S_{r}+\alpha_{r} \dot{T}$

Table 2-1 summarizes the strain contributions associated with each fuel particle structure. Because creep and swelling in the SiC layer are small relative to that of PyC and because of uncertainty in these properties for $\mathrm{SiC}$, the $\mathrm{SiC}$ strains do not currently include contributions from creep or swelling. The fuel particle kernel is not considered to deform structurally, though a model is included in PARFUME to predict kernel volumetric changes over time. 
Table 2-1. Fuel particle strain contributions.

\begin{tabular}{|c|c|c|c|c|}
\hline Fuel Particle Component & Elastic Strain & Creep Strain & Swelling Strain & Thermal Strain \\
\hline Kernel & No & No & Yes & No \\
\hline Buffer & Yes & Yes & Yes & Yes \\
\hline IPyC & Yes & Yes & Yes & Yes \\
\hline SiC & Yes & No & No & Yes \\
\hline OPyC & Yes & Yes & Yes & Yes \\
\hline
\end{tabular}

The stress state in a fuel particle depends on the internal gas pressure that exists during either normal reactor operation or an accident condition. Gas pressures are calculated according to the Redlich-Kwong equation of state and account for the generation of $\mathrm{CO}$ and the release of noble FP gases.

\subsubsection{Compute Failure Probability (Step 4)}

Once stresses have been determined, they are used in conjunction with Weibull statistics to determine particle failure probabilities in the fuel performance model. Assuming that the fuel particle failures follow a Weibull statistical distribution, the failure probability (for example, of the $\mathrm{SiC}$ layer) is computed by inserting the calculated stress into Equation (2-3), where the characteristic strength $\left(\sigma_{o}\right)$ and Weibull modulus $(m)$ are determined from experimental data.

$P_{f}=1-e^{-\int\left(\frac{\sigma}{\sigma_{o}}\right)^{m}} d V$

The user is provided with Monte Carlo, full-integration, and fast-integration solution scheme options to determine failure probability.

\subsubsection{Compute Fission Product Diffusion (Step 5)}

The simulation of FP transport via diffusion from the fuel through the particle coating layers to the surrounding fuel element graphite matrix, and finally to the coolant boundary, is accomplished using the following fundamental transport equation of Equation (2-4), where the flux is driven by FP concentration gradients and temperature gradients as shown in Equation (2-5).

$\frac{\partial C}{\partial t}=-\nabla \bullet J+S$

$J=-D\left(\nabla C+\frac{Q^{\prime} C}{R T^{2}} \nabla T\right)$

Similar to the temperature profile analyses, "micro" and "macro" diffusion analyses are performed. The micro analysis is based on a model having five different materials (kernel, buffer, IPyC, SiC, and $\mathrm{OPyC}$ ). The macro solution is based on a model having two materials: the graphite-containing fuel particles and the surrounding graphite without fuel particles.

Results from all of the diffusion analyses are integrated over time to produce a total FP release fraction from the fuel element. This is done for each of the FPs under consideration. 


\subsection{Verification and Validation}

One of the most important steps in code development and application is the verification and validation (V\&V) process. According to the American Institute of Aeronautics and Astronautics (AIAA), verification is "the process of determining that a model implementation accurately represents the developer's conceptual description of the model and the solution to the model," while validation is "the process of determining the degree to which a model is an accurate representation of the real world from the perspective of the intended uses of the model."11

In general, verification is the responsibility of the organization developing the code, while simulation validation primarily resides with the user. Ultimately, code verification and subsequent validation help establish the predictive capability of the code and confidence in simulation results. To date, only V\&V "guidelines" have been agreed upon by professional societies, leaving the development of a detailed step-by-step V\&V procedure to managers, code developers, and computational analysts. ${ }^{11,12,13}$

Currently, a formal V\&V plan has not been established for PARFUME, although local (i.e., in-house) processes coupled with guidelines presented in several V\&V documents have been utilized to establish confidence in PARFUME results. As a formal V\&V plan matures, details of the V\&V of PARFUME will be presented in future releases of this user guide.

\subsection{Future Development}

PARFUME development is a perennial process requiring, for example, a diligent effort to maintain the code up-to-date with the latest models, software, and hardware architecture. Plans will include several new models. For example, finite element stress analyses of thinned and corroded SiC layers have been performed. These analyses will be coupled with (yet to be developed) application criteria to form another failure algorithm. Also, an initially defective SiC layer model will be incorporated into PARFUME. 


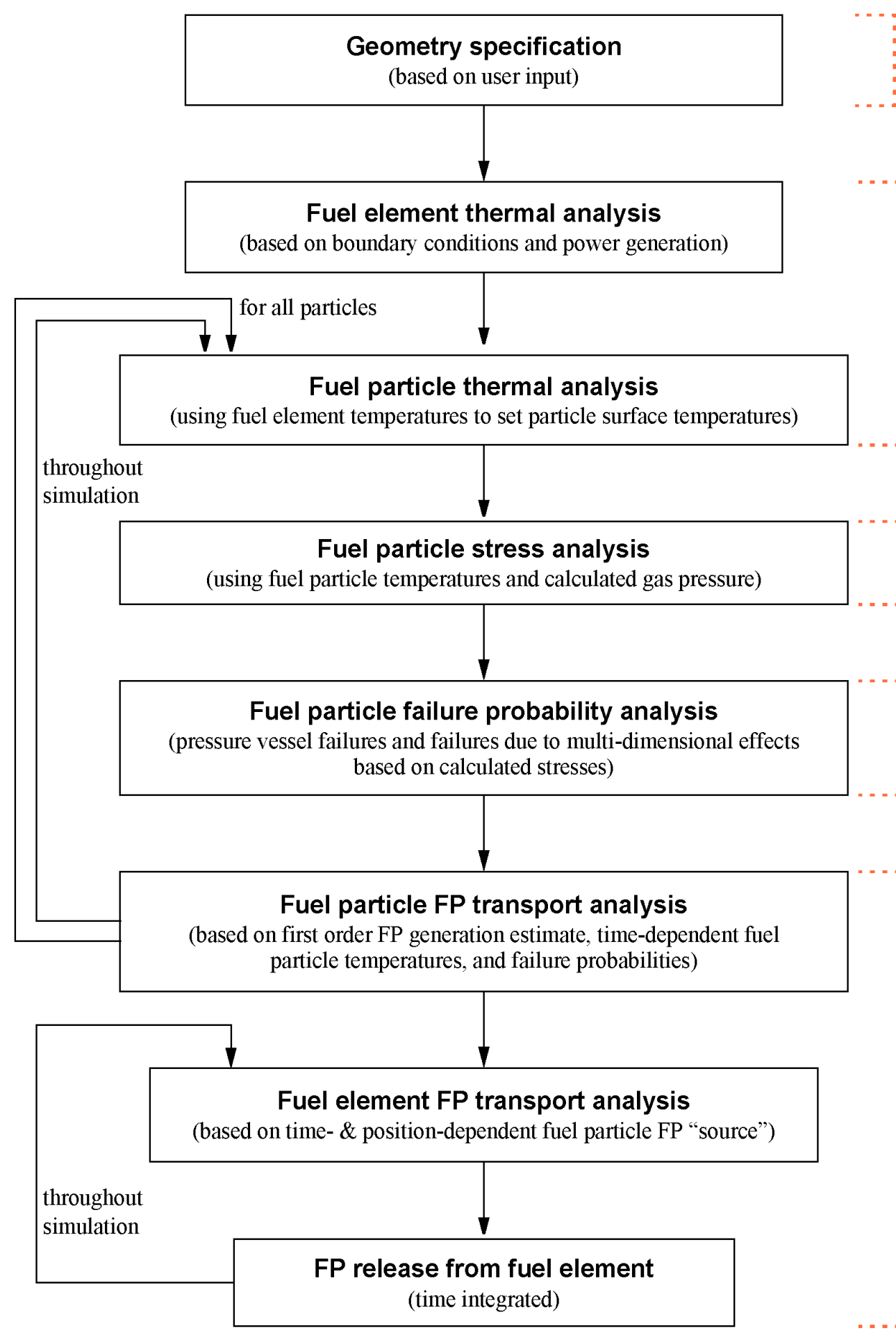

Step 1

Step 2

Step 3

Step 4

Step 5

Figure 2-4. General solution procedure. 


\section{PARFUME CODE INPUT}

This section presents a description of code input parameters; an example input deck is provided in Section 6. In addition, a summary of the input deck parameters, including default values and units, is located in Appendix A.

In this report, the input deck terminology refers to the six-digit number "XXXXXX" as the "card number." The first three digits of the card number are called the "card series," while the final three digits are called the "card sequence." For example, the card number 201001 consists of 6 digits. The digits 201 represent the card series, and the digits 001 represent the card sequence.

\subsection{Run Parameters}

\subsubsection{CARD 100001 (Simulation Description)}

\subsubsection{1 "title"}

This card allows users to name their simulation. This parameter is a character string, which may be up to 60 characters long.

\subsubsection{CARD 101001 (Solution Schemes)}

\subsubsection{1 “pfss" (PARFUME Solution Scheme)}

This parameter allows the user to select one of three available solution schemes: $\mathrm{pfss}=$ solution scheme: $0=$ Monte Carlo, $1=$ full integration, $2=$ fast integration.

In the Monte Carlo routine of PARFUME, stresses are analyzed for a statistically sampled batch of particles. In the integration approach, the failure probability $P_{f}$ for a particle batch will be formulated in terms of an integral. The fast integration method, an integration approximation, was developed to substantially reduce the time required to perform the integration with only a minimal loss of accuracy. Additional details of this solution scheme can be found in Section 5.4 of Reference 1.

\subsubsection{2 "ncases"}

This parameter represents the number of coated fuel particles (CFP) in a "Monte Carlo" solution scheme (i.e., sample size); if another solution scheme such as fast integration is selected, the parameter is not used. In general, the larger the value of ncases, the more likely it is that a more accurate estimate of failure probability will be obtained, but this larger sample size could result in longer computational time. A good rule-of-thumb is that ncases should be on the order of ten divided by the expected failure probability. For example, if a failure probability on the order of $1 \times 10^{-4}$ is being analyzed, the value of ncases should be on the order of $1 \times 10^{5}$.

\subsubsection{3 "nburp"}

This parameter controls the frequency of periodic runtime updates, so the user can tell the code is running. Figure 3-1 shows the screen output using different values. Note that the "Elapsed Time (s)" screen output is based on the time the program was first executed. For example, the elapsed time data in Figure 3-1 shows that the it took the user about 2-3 seconds longer to enter the data file for the "nburp=200" simulation. 


\begin{tabular}{cccc}
\multicolumn{2}{c}{$(\mathrm{nburp}=100)$} & \multicolumn{2}{c}{$(\mathrm{nburp}=200)$} \\
Increment & Elapsed & Increment & Elapsed \\
Completed & Time $(\mathrm{s})$ & - Completed & Time $(\mathrm{s})$ \\
-100 & 7. & 200 & 11. \\
200 & 8. & 400 & 13. \\
300 & 10. & 600 & 16. \\
400 & 11. & 800 & 19. \\
500 & 12. & 1000 & \\
600 & 14. & & \\
700 & 15. & & \\
800 & 17. & & \\
900 & 18. & & \\
1000 & 20. & &
\end{tabular}

Figure 3-1. PARFUME screen output with different "nburp" values.

\subsubsection{4 "sample"}

This parameter determines whether (input) parameter variations - for example, particle geometry variations such as kernel diameter standard deviation - are considered. An input value of " 0 " turns this option off; therefore, standard deviation is assumed to equal zero. An input value of " 1 " turns this option on; therefore, the standard deviation value is set based on user input values specified in card series 103 and 104.

\subsubsection{5 “dtf”}

This parameter is used during a FP transport analysis. It controls activation of designed-to-fail (dtf") particle models (i.e., single-layer CFP or a BISO CFP), which are specifically designed to fail. This setting is not fully implemented in PARFUME. An input value of " 0 " turns this option off. An input value of " 1 " turns this option on. The default value is " 0. ."

\subsubsection{6 "iseed"}

This parameter allows the user to specify a "random number seed" for Monte Carlo calculations in order to initialize the random number generator; it is not used otherwise. The default value is " 305 ."

\subsubsection{CARD 101002 (Models)}

This card allows selection of models used for studying particle failure modes such as debonding, and asphericity.

\subsubsection{1 “idebondp"}

This parameter controls activation of the debonding models: $0=$ off, $1=$ on.

Additional debonding parameters are set in card series 403 . 


\subsubsection{2 "ifacet"}

This parameter controls activation of faceting models: $0=$ off, $1=$ on.

Additional faceting parameters are set in card series 402 .

\subsubsection{3 "rbvalue"}

This parameter controls release-to-birth (R/B) calculations for short-term FP diffusion analysis, which is used for source-term analyses. The term "birth" represents birth from fission, and the term "release" represents the release of FPs to the environment surrounding the fuel element: $\leq 0=$ no $\mathrm{R} / \mathrm{B}, 1=\mathrm{Kr}-85 \mathrm{~m}$, $>1=12$ nuclides.

The 12 nuclides include: $\mathrm{Kr}-85 \mathrm{~m}$ (m represents metastable state), Kr-87, Kr-88, Kr-89, Kr-90, Xe-131m, Xe-133, Xe-135, Xe-135m, Xe-137, Xe-138, and Xe-139. Additional details of this model can be found in Section 6 of Reference 1.

\subsubsection{4 "comodel"}

This parameter controls the activation of $\mathrm{CO}$ production models: $1=$ original model (no $\mathrm{CO}$ production), 2 = GA (Kovaks) model, $3=$ HSC model, $4=$ German (Proksch) model. Additional details of this model can be found in Section 4.2.2 of Reference 1. This term allows for CO contribution to particle pressure.

\subsubsection{5 "fgmodel"}

This parameter controls activation of fission gas $(\mathrm{Kr}$ and $\mathrm{Xe})$ release fraction models: $1=$ original model $(100 \%$ release), $2=$ Booth equivalent sphere model. Additional details of fission gas release can be found in Section 4 of Reference 1. This term allows for $\mathrm{Kr}$ and $\mathrm{Xe}$ contributions to particle pressure.

\subsubsection{6 “idebug"}

This parameter is used for code development purposes. Contrary to its name, this parameter is not used for debugging the code. This parameter controls activation of additional output data, which is used in conjunction with ABAQUS in developing "h functions." Additional temporal data includes: particle nominal pressure and particle nominal $\mathrm{OPyC}, \mathrm{SiC}$, and IPyC temperature. If this parameter is set equal to 0 , no additional output data will be included in the results file; setting this parameter equal to 1 results in additional temporal data output. Figure 3-2 is an example of the temporal outputs. Use of this parameter is not recommended. Additional information on "h functions" can be found in Section 5.2 of Reference 1. 
PARTICLE nominal IPyC temp (in K) vs. ABAQUS time

$0.0000 \mathrm{E}+00,1273.000,0.1258 \mathrm{E}+05,1273.185,0.2516 \mathrm{E}+05,1273.185,0.3774 \mathrm{E}+05,1273.185$,

$0.5031 \mathrm{E}+05,1273.185,0.6289 \mathrm{E}+05,1273.185,0.7547 \mathrm{E}+05,1273.185,0.8805 \mathrm{E}+05,1273.185$,

$0.1006 \mathrm{E}+06,1273.185,0.1132 \mathrm{E}+06,1273.185,0.1258 \mathrm{E}+06,1273.185,0.1384 \mathrm{E}+06,1273.185$,

$0.1509 \mathrm{E}+06,1273.185,0.1635 \mathrm{E}+06,1273.185,0.1761 \mathrm{E}+06,1273.185,0.1887 \mathrm{E}+06,1273.185$,

$0.2013 \mathrm{E}+06,1273.185,0.2138 \mathrm{E}+06,1273.185,0.2264 \mathrm{E}+06,1273.185,0.2390 \mathrm{E}+06,1273.185$,

$0.2516 \mathrm{E}+06,1273.185,0.2642 \mathrm{E}+06,1273.185,0.2767 \mathrm{E}+06,1273.185,0.2893 \mathrm{E}+06,1273.185$,

$0.3019 \mathrm{E}+06,1273.185,0.3145 \mathrm{E}+06,1273.185,0.3270 \mathrm{E}+06,1273.185,0.3396 \mathrm{E}+06,1273.185$,

$0.3522 \mathrm{E}+06,1273.185,0.3648 \mathrm{E}+06,1273.185,0.3774 \mathrm{E}+06,1273.185,0.3899 \mathrm{E}+06,1273.185$,

$0.4025 \mathrm{E}+06,1273.185,0.4151 \mathrm{E}+06,1273.185,0.4277 \mathrm{E}+06,1273.185,0.4403 \mathrm{E}+06,1273.185$,

Figure 3-2. Example output with "idebug" =1.

\subsection{Fuel Characteristics}

\subsubsection{CARD 102001 (Fuel Properties)}

This card contains fuel characteristic user input.

\subsubsection{1 “u235enr(\%)"}

This parameter represents the fuel kernel U-235 enrichment (wt \%).

\subsubsection{2 "ourat"}

This parameter represents the oxygen-to-uranium atom ratio required for $\mathrm{UO}_{2}$ or $\mathrm{UCO}$ fuel analysis.

\subsubsection{3 "curat"}

This parameter represents the carbon-to-uranium atom ratio required for UCO fuel analysis.

\subsubsection{CARD 103001 (Kernel Properties)}

The card contains the fuel particle material properties.

\subsubsection{1 "kernd"}

This parameter represents kernel density $\left(\mathrm{Mg} / \mathrm{m}^{3}\right)$, which is typically supplied by the manufacturer.

\subsubsection{2 "kernt"}

This parameter represents the theoretical kernel density $\left(\mathrm{Mg} / \mathrm{m}^{3}\right)$, which is typically obtained from a handbook. This parameter is used in the void volume computation. The default value is $11.03 \mathrm{Mg} / \mathrm{m}^{3}$. 


\subsubsection{CARD 103002 (Buffer Properties)}

This card contains the buffer particle material properties.

\subsubsection{1 "buffd"}

This parameter represents the buffer density $\left(\mathrm{Mg} / \mathrm{m}^{3}\right)$, which is typically supplied by the manufacturer.

\subsubsection{2 "bufft"}

The theoretical buffer density represents the maximum densification that can occur in buffer density $\left(\mathrm{Mg} / \mathrm{m}^{3}\right)$, which is typically obtained from a handbook. The default value is $2.25 \mathrm{Mg} / \mathrm{m}^{3}$.

\subsubsection{CARD 103003 (IPyC Properties)}

\subsubsection{1 “ipycdn”}

This parameter represents the mean IPyC density $\left(\mathrm{Mg} / \mathrm{m}^{3}\right)$.

\subsubsection{2 “ipycdvar"}

This parameter represents the IPyC density standard deviation $\left(\mathrm{Mg} / \mathrm{m}^{3}\right)$.

\subsubsection{CARD 103005 (OPyC Properties)}

\subsubsection{1 “opycdn"}

This parameter represents the mean OPyC density $\left(\mathrm{Mg} / \mathrm{m}^{3}\right)$.

\subsubsection{2 "opycdvar"}

This parameter represents the OPyC density standard deviation $\left(\mathrm{Mg} / \mathrm{m}^{3}\right)$.

\subsubsection{CARD 103013 (IPYC BAF)}

Theoretical information on the BAF is located in Section 7 of Reference 1.

\subsubsection{1 “ibafn"}

This parameter represents the mean IPyC BAF, a measure of the degree of anisotropy. The larger the value, the more anisotropic the material.

\subsubsection{2 “ibafvar"}

This parameter represents the IPyC BAF standard deviation. 


\subsubsection{CARD 103015 (OPYC BAF)}

Theoretical information on the BAF is located in Section 7 of Reference 1.

\subsubsection{1 "obafn"}

This parameter represents the mean OPyC BAF.

\subsubsection{2 "obafvar"}

This parameter represents the $\mathrm{OPyC} \mathrm{BAF}$ standard deviation from the mean.

\subsubsection{CARD 103023 (IPyC Weibull Modulus)}

Theoretical information on the Weibull modulus is located in Section 7 of Reference 1.

\subsubsection{1 "ipycm"}

This parameter represents the IPyC Weibull modulus. The default value is 9.5.

\subsubsection{CARD 103024 (SiC Weibull Modulus)}

\subsubsection{1 "sigm"}

This parameter represents the SiC Weibull modulus. The default value is 6.0.

\subsubsection{CARD 103025 (OPyC Weibull Modulus)}

\subsubsection{1 "opycm"}

This parameter represents the OPyC Weibull modulus. The default value is 9.5.

\subsubsection{CARD 103033 (Poisson's Ratio)}

\subsubsection{1 "cnu"}

This parameter represents the Poisson's ratio in creep for PyCs. The default value is 0.5 .

\subsubsection{2 "cnub"}

This parameter represents the Poisson's ration in creep for the buffer. The default value is 0.5 . 


\subsubsection{CARD 103043 (Creep Amplification Factor)}

\subsubsection{1 "creepampn"}

This parameter represents the mean creep amplification factor, which is applied to amplify (or reduce) the steady-state creep coefficient. The default value is 2.0. Additional details on this parameter are located in Section 7.1.6.1 of Reference 1.

\subsubsection{2 "creepvar"} is 0.0 .

This parameter represents the standard deviation for the creep amplification factor. The default value

\subsubsection{CARD 103054 (Zrc Modeling)}

\subsubsection{1 "zrc"}

This parameter controls activation of the $\mathrm{ZrC}$ model: $0=$ off, $1=$ on. When the $\mathrm{ZrC}$ model is chosen, the material properties for $\mathrm{SiC}$ are replaced with the material properties for $\mathrm{ZrC}$, but the geometric parameters specified by the user on the input data deck for $\mathrm{SiC}$ remain the same. The default value is 0 .

\subsubsection{2 "zrcp"}

This parameter represents the fraction of $\mathrm{ZrC}$ theoretical density, where four options (i.e., 1, 2, 3, 4) are available to the user. Option 1 represents a value of 0.96 , Option 2 represents a value of 0.85 , Option 3 represents a value of 0.80 , and Option 4 represents a value of 0.77 . The default value is 1 .

\subsubsection{CARD 103061 (Defective SiC Layers)}

\subsubsection{1 fdef}

This parameter represents a place holder variable for the fraction of initial defective SiC layers (currently not used by the code but is planned for a future model). The default value is 0.0 .

\subsection{Particle Geometry}

\subsubsection{CARD 104001 (Kernel Geometry)}

\subsubsection{1 "kerndia"}

This parameter represents the mean kernel diameter $(\mu \mathrm{m})$.

\subsubsection{2 "kernvar"}

This parameter represents the kernel diameter standard deviation $(\mu \mathrm{m})$. 


\subsubsection{CARD 104002 (Buffer Geometry)}

\subsubsection{1 "buffthk"}

This parameter represents the mean buffer thickness $(\mu \mathrm{m})$.

\subsubsection{2 "buffivar"}

This parameter represents the buffer thickness standard deviation $(\mu \mathrm{m})$ from the mean.

\subsubsection{CARD 104003 (IPyC Geometry)}

\subsubsection{1 “ipycthk"}

This parameter represents the mean IPyC thickness $(\mu \mathrm{m})$.

\subsubsection{2 "ipycvar"}

This parameter represents the IPyC thickness standard deviation $(\mu \mathrm{m})$.

\subsubsection{CARD 104004 (SiC Geometry)}

\subsubsection{1 "sicthk"}

This parameter represents the mean $\mathrm{SiC}$ thickness $(\mu \mathrm{m})$.

\subsubsection{2 "sicvar"}

This parameter represents the $\mathrm{SiC}$ thickness standard deviation $(\mu \mathrm{m})$.

\subsubsection{CARD 104005 (OPyC geometry)}

\subsubsection{1 "opycthk"}

This parameter represents the mean OPyC thickness $(\mu \mathrm{m})$.

\subsubsection{2 "opycvar"}

This parameter represents the OPyC thickness standard deviation $(\mu \mathrm{m})$.

\subsection{Fuel Matrix Description}

\subsubsection{CARD 105001 (Fuel Element Types)}

Within PARFUME, three different fuel element geometries (i.e., plane, cylindrical, and spherical) may be simulated in one dimension. Each geometry is modeled by averaging spherical fuel particles, void regions (i.e., coolant channels), and the graphite matrix. This modeling technique is necessary in order to 
capture the physical behavior of the fuel elements while eliminating the complexities (i.e., computational requirements) of modeling the detailed composition of the fuel element.

Three separate options are available to specify input parameters for either the pebble bed (PEBBLEBED), prismatic (PRISMATIC), or plane geometry (PLANEGEOM) fuel element.

\subsubsection{CARD 105011 (PEBBLEBED - Particle Density and Mesh)}

\subsubsection{1 "partnum"}

This parameter represents the number of coated fuel particles (CFPs) per pebble.

\subsubsection{2 "ngnfm"}

This parameter represents the number of "global" nodes in the "fuel matrix" region. Referring to Figure 2-3b, "ngnfm $=3$ ". Note that two co-located global nodes are present at the interface of the fuel matrix and shell.

\subsubsection{3 “ngn"}

This parameter represents the total number of "global" nodes in "fuel matrix" plus the "unfueled shell" region. Referring to Figure 2-3b, "ngn $=8$ ". Note that two co-located global nodes are present at the interface of the fuel matrix and shell.

\subsubsection{CARD 105021 (PEBBLEBED - Geometry)}

\subsubsection{1 "pebdia"}

This parameter represents the pebble diameter (m) of a single pebble.

\subsubsection{2 "pebcldtk"} (m).

This parameter represents the thickness of the non-fueled region on the outer surface of the pebble

\subsubsection{CARD 105031 (PEBBLEBED - Density)}

\subsubsection{1 "fmden"}

This parameter represents the density of the fuel matrix material $\left(\mathrm{Mg} / \mathrm{m}^{3}\right)$. The default value is 1.7 .

\subsection{CARD 105041 (PEBBLEBED - Uranium Contamination)}

\subsubsection{1 "ucontam"}

This parameter represents the fraction of uranium contamination in the fuel matrix. 


\subsubsection{CARD 105011 (PRISMATIC - Particle Density and Mesh)}

\subsubsection{1 "partnum"}

This parameter represents the number of CFPs per compact per meter of fuel element.

\subsubsection{2 "ngnfm"}

This parameter represents the number of "global" nodes in the "fuel matrix" region. Referring to Figure 2-3b, "ngnfm $=3$ ". Note that two global nodes are present at the interface of the fuel matrix and shell.

\subsubsection{3 “ngn"}

This parameter represents the total number of "global" nodes in "fuel matrix" plus the "unfueled shell" region. Referring to Figure 2-3b, "ngn $=8$ ". Note that two global nodes are present at the interface of the fuel matrix and shell.

\subsubsection{CARD 105021 (PRISMATIC - Geometry)}

Refer to Figure 2-2 for a description of this geometry.

\subsubsection{1 "fueldia"}

This parameter represents the diameter of the fuel compact (m).

\subsubsection{2 "cooldia"}

This parameter represents the coolant channel diameter $(\mathrm{m})$.

\subsubsection{3 "fuelpitch"}

This parameter represents the fuel compact pitch, the center-to-center distance between fuel compacts arranged in an array.

\subsubsection{4 "height"}

This parameter represents the height of the fuel compact (m).

\subsubsection{CARD 105031 (PRISMATIC - Density)}

\subsubsection{1 "fmden"}

This parameter represents the density of the fuel matrix material $\left(\mathrm{Mg} / \mathrm{m}^{3}\right)$. The default value is 1.7 . 


\subsubsection{CARD 105041 (PRISMATIC - Uranium Contamination)}

\subsubsection{1 "ucontam"}

This parameter represents the fraction of uranium contamination in the fuel matrix.

\subsubsection{CARD 105011 (PLANEGEOM - Particle Density and Mesh)}

\subsubsection{1 "partnum"}

This parameter represents the number of CFPs per slab per square meter of surface area.

\subsubsection{2 “ngnfm"}

This parameter represents the number of "global" nodes in the "fuel matrix" region. Referring to Figure 2-3b, "ngnfm $=3$ ". Note that two global nodes are present at the interface of the fuel matrix and shell.)

\subsubsection{3 "ngn"}

This parameter represents the total number of "global" nodes in "fuel matrix" plus the "unfueled shell" region. Referring to Figure 2-3b, "ngn $=8$ ". Note that two global nodes are present at the interface of the fuel matrix and shell.

\subsubsection{CARD 105021 (PLANEGEOM - Geometry)}

Refer to Figure 2-1 for a description of this geometry.

\subsubsection{1 "fmthk"}

This parameter represents the thickness of the fuel meat (m).

\subsubsection{2 “cldthk"}

This parameter represents the thickness of the fuel cladding (m).

\subsubsection{3 "sarea"}

This parameter represents the surface area of the fuel plate $\left(\mathrm{m}^{2}\right)$.

\subsubsection{CARD 105031 (PLANEGEOM - Density)}

\subsubsection{1 "fmolen"}

This parameter represents the density of the fuel matrix material $\left(\mathrm{Mg} / \mathrm{m}^{3}\right)$. The default value is 1.7 . 


\subsubsection{CARD 105041 (PLANEGEOM - Uranium Contamination)}

\subsubsection{1 "ucontam"}

This parameter represents the fraction of uranium contamination in the fuel matrix.

\subsection{Reactor Temperature Options}

\subsubsection{CARD 106001 (Reactor Temperature Options)}

This parameter allows the user to select a reactor temperature solution option, "rtmpopt".

Current solution schemes include: FIFD-CALC = fully implicit finite difference calculation, TEMP-DATA = allows users to input independently calculated temperatures, and VOLAVGTMP = allows users to select an adiabatic analyses.

\subsubsection{1 "FIFD-CALC"}

This option invokes the finite difference scheme to solve the heat conduction equation. The solution scheme is described in Section 3.1 of Reference 1.

\subsubsection{2 "TEMP-DATA"}

This option allows the user to input independently calculated temperatures - for example, those obtained from experimental data or computer-aided engineering (CAE) software (e.g., ABAQUS, Star-CCM+).

With respect to ABAQUS data, PARFUME reads the data, identifies the maximum and minimum temperature values for each volume element, divides the identified data into 21 bins, averages the temperatures in each bin, and utilizes the average temperatures in probability calculations. This CAE data must be in a specified format consistent with ABAQUS. Note that if this option is selected and an ABAQUS input file is not located within the same directory as the PARFUME executable file, the user will be prompted as follows:

"Input (x.abq) file was not found

Please enter 'x'.abq filename or QUIT'

Additionally, the CAE file name must be the same as the PARFUME input data file, and the file must have an "x.abq" file type.

\subsubsection{VOLAVGTMP”}

This option allows the user to select a volume-averaged temperature profile for heat transfer analysis in the fuel element. 


\subsubsection{CARD 106021 (Global Node Temperatures)}

\subsubsection{1 "tgi(k)"}

This parameter allows users to specify temperatures (Kelvin) at the fuel matrix global nodes when the "FIFD-CALC" option is selected. When this option is selected, the values input represent the fuel element spatial temperatures.

\subsubsection{2 "ntgi"}

This parameter allows users to specify the associated fuel matrix node for the specified temperature when the "FIFD-CALC" option is selected. When this option is selected, the values input represent the fuel element nodes. Note that "node 1" is always located at the line of symmetry for the respective geometry (see Figure 2-1).

\subsection{Diffusion Model}

\subsubsection{CARD 201001 (Diffusion Model)}

\subsubsection{1 fpspecie}

This parameter turns on diffusion, where the diffusive behavior of six "long-lived" FP speciesiodine (I), silver (Ag), cesium (Cs), strontium ( $\mathrm{Sr})$, krypton $(\mathrm{Kr})$, and xenon (Xe) — can be modeled.

\subsection{Environmental Parameters}

\subsubsection{CARD 301001 (Fluence v. Time Input)}

\subsection{2 "ttime"}

This parameter represents the time variable and allows users to specify the time history (days) of neutron exposure.

\subsection{3 "flu"}

This parameter represents the fluence level and allows users to specify the time history of neutron exposure $\left(10^{25} \mathrm{n} / \mathrm{m}^{2}, \mathrm{E}>0.18 \mathrm{MeV}\right)$.

\subsubsection{CARD 302001 (Burnup v. Fluence Input)}

\subsubsection{1 "flu"}

This parameter represents the fluence level and allows users to specify the burnup history based on neutron exposure $\left(10^{25} \mathrm{n} / \mathrm{m}^{2}, \mathrm{E}>0.18 \mathrm{MeV}\right)$. 


\subsubsection{2 “bup"}

This parameter represents the burnup level (\%FIMA) and allows users to specify the burnup history based on neutron exposure $\left(10^{25} \mathrm{n} / \mathrm{m}^{2}, \mathrm{E}>0.18 \mathrm{MeV}\right)$.

\subsubsection{CARD 303001 (External Pressure v. Fluence Input)}

\subsubsection{1 "flu"}

This parameter represents the fluence level and allows users to specify the burnup history based on neutron exposure $\left(10^{25} \mathrm{n} / \mathrm{m}^{2}, \mathrm{E}>0.18 \mathrm{MeV}\right)$.

\subsubsection{2 "pamb"}

This parameter represents the ambient pressure (MPa) and allows users to specify the ambient pressure history based on neutron exposure $\left(10^{25} \mathrm{n} / \mathrm{m}^{2}, \mathrm{E}>0.18 \mathrm{MeV}\right)$.

\subsubsection{CARD 304001 (Boundary Temperature v- Fluence Input)}

This card and its associated parameters are available only when "rtmpopt=FIFD-CALC" is selected.

\subsubsection{1 “flu"}

This parameter represents the fluence level and allows users to specify the boundary temperature history based on neutron exposure $\left(10^{25} \mathrm{n} / \mathrm{m}^{2}, \mathrm{E}>0.18 \mathrm{MeV}\right)$.

\subsubsection{2 “btemp"}

This parameter represents the boundary temperature $(\mathrm{K})$ and allows users to specify the boundary temperature history based on neutron exposure $\left(10^{25} \mathrm{n} / \mathrm{m}^{2}, \mathrm{E}>0.18 \mathrm{MeV}\right)$.

\subsubsection{CARD 306001 (Time Heatup Starts and Irradiation Ends)}

\subsubsection{1 "thus"}

This parameter represents the point in time in which heatup starts (days) and irradiation ends.

\subsection{Correlation Parameters and Coefficients}

\subsubsection{CARD 401001 (Correlation Coefficients - IPyC Cracking)}

\subsubsection{1 sigcro"}

This parameter represents SiC mean strength value with IPyC cracking (MPa).

\subsubsection{2 "umc"}

This parameter represents $\mathrm{SiC}$ stress for cracked CFP where all parameters are at mean values (MPa). 


\subsubsection{CARDS 401002 through 401012 (Correlation Coefficients "c1c", "c2c")}

\subsubsection{1 "c1c" and "c2c"}

These parameters represent the polynomial coefficients necessary to correlate a 1-D PARFUME solution with a multi-dimensional solution from detailed ABAQUS calculations for IPyC cracking.

\subsubsection{CARD 402001 (Correlation Coefficients - Asphericity)}

\subsubsection{1 "siga0"}

This parameter represents the mean $\mathrm{SiC}$ strength in a faceted CFP $(\mathrm{MPa})$.

\subsubsection{2 "um"}

This parameter represents the $\mathrm{SiC}$ stress, at the minimum value, for a faceted $\mathrm{CFP}$ where all parameters are at mean values $(\mathrm{MPa})$.

\subsubsection{3 "delum"}

This parameter represents the $\mathrm{SiC}$ stress, at the maximum value or at the end of the solution, for a faceted CFP where all parameters are at mean values $(\mathrm{MPa})$.

\subsubsection{4 "aration"}

This parameter represents the mean aspect ratio, which is the ratio of the maximum to minimum diameter.

\subsubsection{5 "aratvar"}

This parameter represents the standard deviation of the aspect ratio.

\subsubsection{CARDS 402002 through 402013 (Coefficients “c1a”, "c2a”, “d1a”, “d2a")}

These parameters represent the polynomial coefficients to correlate a 1-D PARFUME solution with a multi-dimension solution from detailed ABAQUS calculations for asphericity.

\subsubsection{CARD 403001 (Correlation Coefficients - Partial IPyC Debonding)}

\subsubsection{1 "sigd0"}

This parameter represents the mean SiC strength for a debonded CFP (MPa).

\subsubsection{2 "umd"}

This parameter represents the $\mathrm{SiC}$ stress, at the minimum value, for a debonded $\mathrm{CFP}$ where all parameters are at mean values (MPa). 


\subsubsection{3 "bondo"}

This parameter represents the IPyC bond strength, at the maximum value or at the end of the solution, for a debonded CFP where all parameters are at mean values (MPa).

\subsubsection{4 "bondOvar"}

This parameter represents the bond strength standard deviation.

\subsubsection{CARDS 403002 through 403013 (Coefficients "c1d" and "c2d")}

These parameters represent the polynomial coefficients necessary to correlate a 1-D PARFUME solution with a multi-dimensional solution from detailed ABAQUS calculations for IPyC debonding. 


\section{INSTALLATION AND EXECUTION}

\subsection{Introduction}

PARFUME is written in American National Standards Institute (ANSI) "standard" FORTRAN 77, but the code has been compiled using an Intel Visual Fortran 90 compiler. Currently, support is provided only for Linux platforms; Microsoft operating systems are not supported. Although it is expected that PARFUME v2.19 will operate properly on most Linux operating systems, the current version of the program has only been tested on SUSE 10.3.

This section presents a summary of the procedure to install and execute PARFUME on Linux platforms.

\subsubsection{Transmittal Media}

PARFUME is transmitted via CD-ROM disk.

\subsubsection{Hardware/Software Requirements}

Linux operating system

486DX or higher processor

$25 \mathrm{MB}$ of available hard disk space

\subsubsection{Linux Quick Installation Guide}

\subsubsection{Installation/Execution Steps}

Table 4-1. PARFUME installation steps.

\begin{tabular}{cl}
\hline Step No. & \multicolumn{1}{c}{ Description } \\
\hline 1 & Insert CD into CD-ROM drive. \\
2 & Transfer the file '*.X' to the hard drive. \\
3 & $\begin{array}{l}\text { At the prompt, type the PARFUME program } \\
\text { version name. }\end{array}$ \\
4 & Follow the instructions on the screen.
\end{tabular}




\section{PARFUME CODE RESULTS}

This section presents a summary of code outputs, error messages, and post processing. Note that a code restart option is not currently available. The complete output file data for PARFUME, including examples and parameters, is presented in Section 6.

\subsection{Output Data File}

The output data deck file name must be consistent with standard MS Windows file-naming protocol; in addition, the output file name is the same name as the input file name, but with a file type of "*.res".

The output data file echoes the parameters that the user input via the data file. In addition, located within the output file after the heading "Input after processing," is the input (i.e., "irradiation history derived from input") data as processed by PARFUME. Specifically, the environmental parameters, described in Table A-1 are processed and output in a table format. The output headings are described below.

\subsubsection{Irradiation History Derived from Input}

\subsubsection{Step}

This output heading is the number of steps, which always begins with the number 1.

\subsubsection{2 ttime (days)}

This output heading is the transient time.

\subsubsection{3 flut (e25 $\mathrm{n} / \mathrm{m} 2)$}

This output heading is the fast fluence specified in $10^{25} \mathrm{n} / \mathrm{m}^{2}, \mathrm{E}>0.18 \mathrm{MeV}$.

\subsubsection{4 bupt (\%FIMA)}

This output heading is the burnup specified in percent fissions per initial metal atom (\%FIMA).

\subsubsection{5 xprest (mpa)}

This output heading is external pressure specified in MPa.

\subsubsection{6 btempt (k)}

This output heading is the boundary temperature specified in degrees Kelvin.

\subsection{Post Processing}

The output data is not in a format to be read directly into a post processing program such as Tecplot or Visit, although the data, with some minor manipulation, can be put into a data format required by MS Excel for data manipulation and graphical display. For example, opening the output data file using MS Excel with "delimited" file type selected and "space" delimiter selected will produce a manageable file for data analysis and plotting. 


\subsection{Error Messages}

PARFUME will issue a warning for most, but not all, erroneous user inputs; nevertheless, users are expected to be familiar with PARFUME and the expectation of realistic inputs. Although it is not practical to list all the error messages that a user might encounter while running PARFUME, a few of the most common error messages are presented and discussed below.

\subsubsection{Missing Card}

In the event that the user fails to include the necessary cards for the simulation, PARFUME will provide the following error message:

failed while reading input because

did not find cards 102001

failed because inputs below are invalid

U235ENR (U235 enrichment \%)

OURAT (oxygen to uranium atom ratio)

CURAT (carbon to uranium atom ratio)

\subsubsection{Invalid Inputs Example}

In this example, a value of $-14 \%$ was entered in the input data deck. The subsequent error message is:

failed because inputs below are invalid

U235ENR (U235 enrichment \%)

\subsubsection{Missing Input Data File}

In the event that the input data file is not located in the same directory as the executable or an incorrect input data file name is used, the following error message will be displayed:

Enter input ('x'.dat) filename:

sample\#1.dat

Input (sample\#1.dat) file was not found

Please enter ' $x$ '.dat filename or QUIT

sample\#1.dat

Input (sample\#1.dat) file was not found

Please enter ' $x$ '.dat filename or QUIT

QUIT 


\subsubsection{Missing ABAQUS data file}

With respect to ABAQUS data, PARFUME reads the data, identifies the maximum and minimum temperature values for each volume element, divides the identified data into 21 bins, averages the temperatures in each bin, and utilizes the average temperatures in probability calculations. This CAE data must be in a specified format consistent with the ABAQUS standard output format. Note that if this option is selected and an ABAQUS input file is not located within the same directory as the PARFUME executable file, the user will be prompted as follow:

"Input (x.abq) file was not found

Please enter 'x'.abq filename or QUIT'

Additionally, the CAE file name must be the same the PARFUME input data file; and the file must have an "x.abq" file type.

\subsubsection{Fuel Element Node Mismatch}

This error occurred due to a mismatch between the input variables "ngn" and "ngti."

failed during history processing because

init temp sequential expansion .ne. NGN

fluence in boundary htc history $>$ EOLFLU 
* CARD 103003 (IPyC properties)

* ipycdn $\left(\mathrm{g} / \mathrm{cm}^{\wedge} 3\right) \quad i p y c d v a r\left(\mathrm{~g} / \mathrm{cm}^{\wedge} 3\right)$

$103003 \quad 1.9 \quad 0$.

* CARD 103005 (OPyC properties)

* opycdn $\left(\mathrm{g} / \mathrm{cm}^{\wedge} 3\right) \quad \operatorname{opycdvar}\left(\mathrm{g} / \mathrm{cm}^{\wedge} 3\right)$

$103005 \quad 1.88 \quad 0$.

$\star$

* CARD 103013 (IPYC Bacon anisotropic factor)

* ibafn ibafvar

$1030131.053 \quad 0$.

* CARD 103015 (OPYC Bacon anisotropic factor)

* obafn obafvar

1030151.0190. *

$\star$

* CARD 103023 (IPyC Weibull modulus)

* ipycm

$103023 \quad 9.50$

* CARD 103024 (SiC Weibull modulus)

* sigm

$103024 \quad 8.02$

* CARD 103025 (OPYC Weibull modulus)

* opycm

$103025 \quad 9.50$

$\star$

* CARD 103033 (Poisson's ratio)

* cnu cnub

$\begin{array}{lll}103033 & 0.5 & 0.5\end{array}$

* CARD 103043 (creep amplification factor)

* creepampn creepvar

$1030432.0 \quad 0.0$ *

* CARD 103054 (Enable ZrC)

* $\quad \operatorname{zrc} \quad \operatorname{zrcp}$

10305401 * 


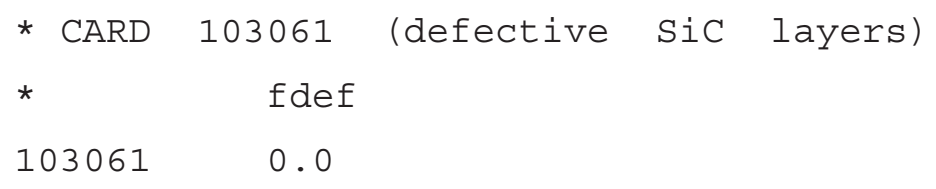


* CARD 105001 (Pebblebed)

$105001 \quad$ PEBBLEBED

* CARD 105011 (Pebblebed)

* partnum (particles/pebble) ngnfm ngn

$105011 \quad 1631.070$

* CARD 105021 (Pebblebed)

* pebdia $(\mathrm{m})$ pebcldtk $(\mathrm{m})$

$105021 \quad .02600 \quad .00300$

* CARD 105031 (Pebblebed)

* fmden ( $\left.\mathrm{g} / \mathrm{Cm}^{\wedge} 3\right)$

$105031 \quad 1.75$

* CARD 105041 (Pebblebed)

* ucontam 105041 1.82E-6

FUEL ELEMENT ENVIRONMENT

* CARD 106001 (fuel temperature option)

* rtmpopt

106001 FIFD-CALC

* CARD 106021 (global node temperatures)

* $\quad \operatorname{tg} i(k)$ ntgi

$106021 \quad 1113.2 \quad 10$

* CARD 201001 (fission product transport description)

* $\quad$ fpspecie

$201001 \quad$ Ag

$\star$

* CARD SERIES 301XXX (fluence v- time input)

* timeirr(days) flu(e25 n/m^2)

301001351 . 3.0

$301002 \quad 352$. 3.0000003

$\begin{array}{lll}301003 & 352.0208 & 5.0000003062\end{array}$

$301004 \quad 352.0833 \quad 5.0000003250$

$\begin{array}{lll}301005 & 352.3125 & 5.0000003937\end{array}$ 


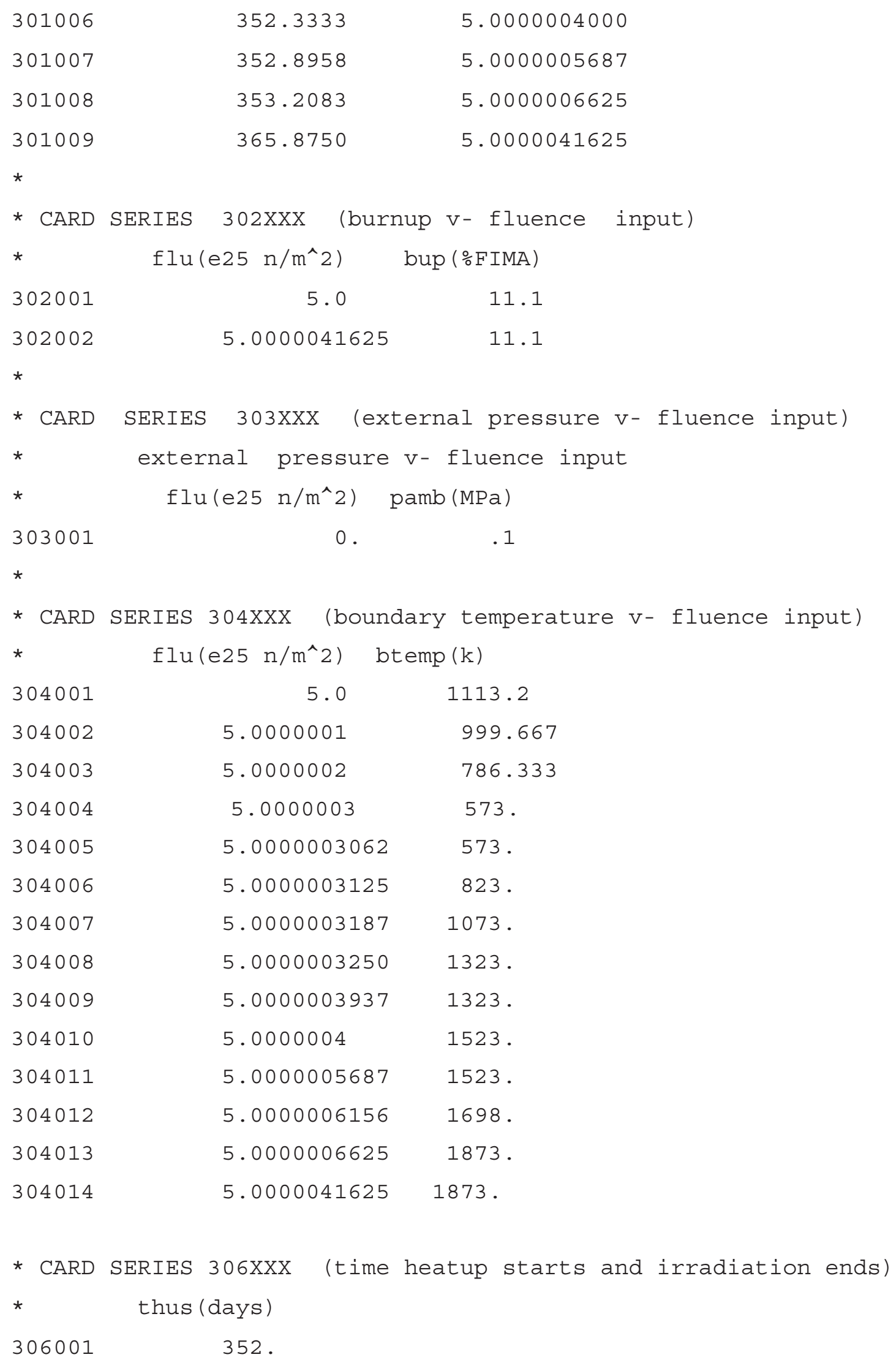




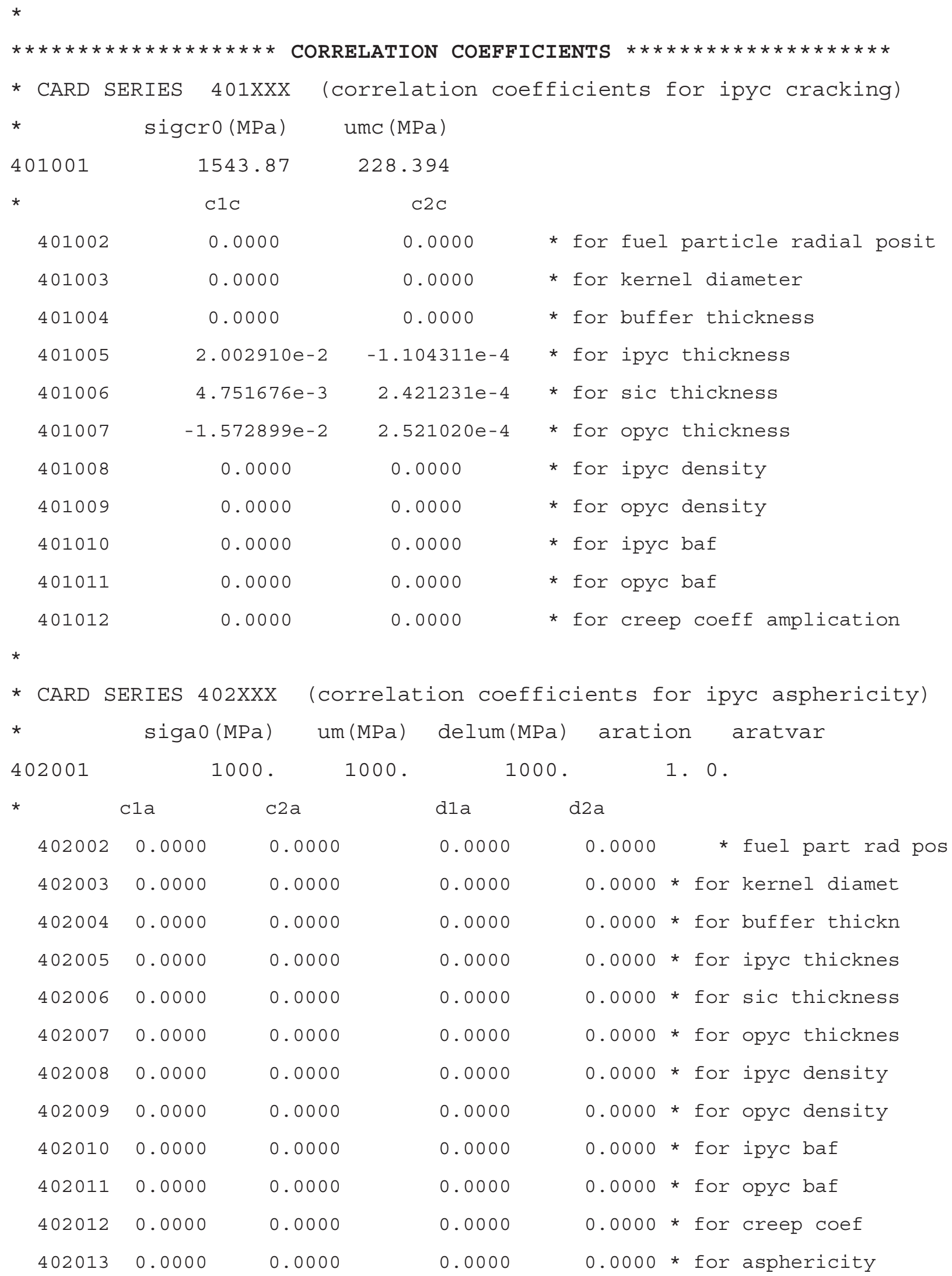




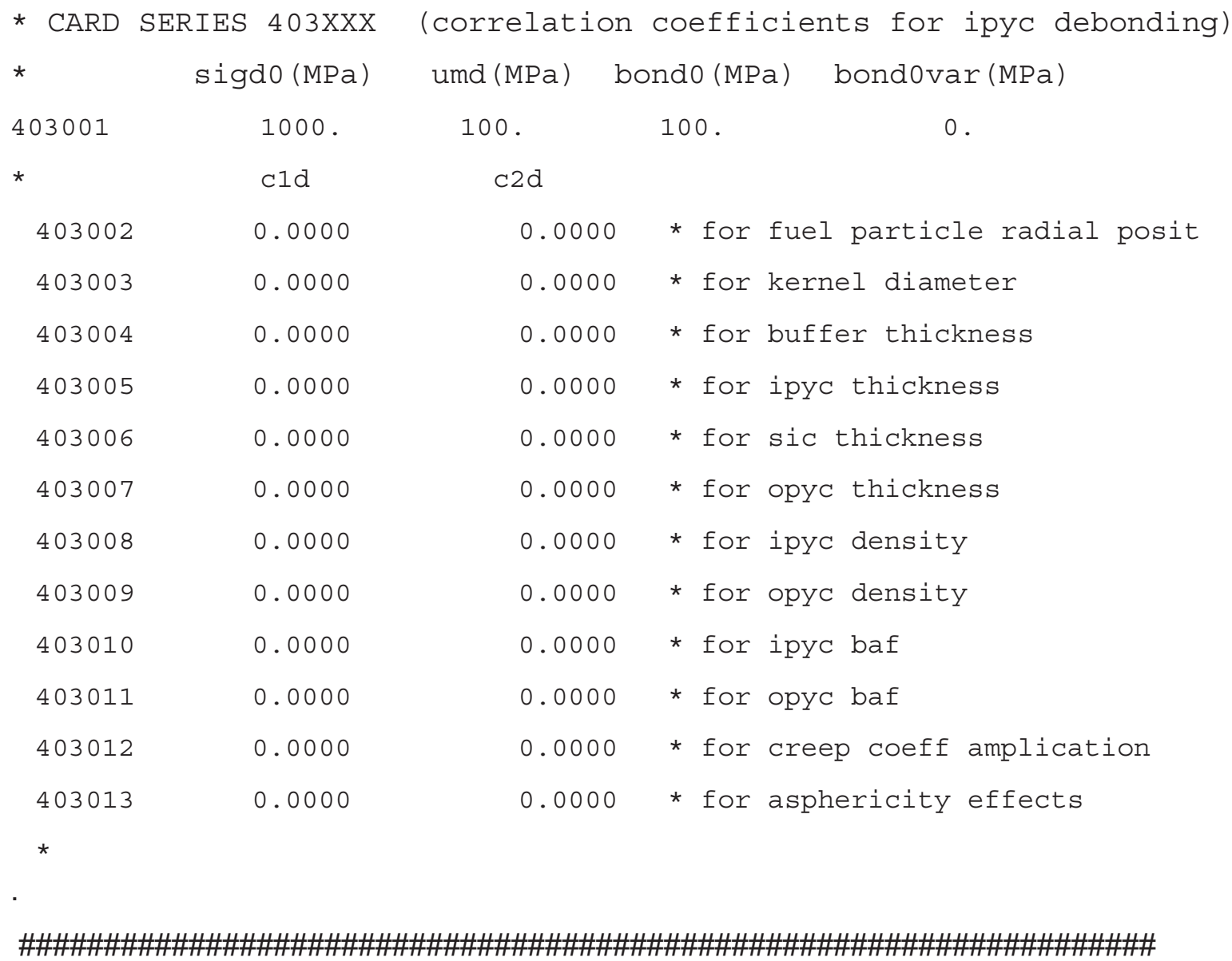

\subsubsection{Input Data Deck Notes}

1. Parameters not specified on the input data deck - for example, values for variables — will default to those specified on Table A-1, located in the Appendix. For example on card number 101001, a value for the variable "dtf" is not specified, so the variable "dtf" will default to a value of " 0 " (design-to-fail analysis is turned off).

2. Note the end of file period '.' required at the end of the file.

3. Card number $10602 \mathrm{X}$ could have been specified as shown below:

$\begin{array}{lcc}* & \begin{array}{c}\text { fuel element temperature options } \\ * \\ 106001\end{array} & \text { FIFD-CALC } \\ * & \text { tgi(k) } & \text { ntgi } \\ 106021 & 1113.2 & 1 \\ 106022 & 1113.2 & 2 \\ 106023 & 1113.2 & 3 \\ 106024 & 1113.2 & 4\end{array}$




$\begin{array}{lll}106025 & 1113.2 & 5 \\ 106026 & 1113.2 & 6 \\ 106027 & 1113.2 & 7 \\ 106028 & 1113.2 & 8 \\ 106029 & 1113.2 & 9 \\ 106030 & 1113.2 & 10\end{array}$

4. Note that the some users may choose to sanitize the data deck of comments and some input parameters that will default to the desired value. An example of such a data deck is presented in Section 6.1.2.1.

\subsubsection{Example "Sanitized" Data Deck (prob\#1_.dat)}

* \$RCSfile: \$

* \$Source: \$

* \$Revision: \$

* \$Date: \$

* \$Author: \$

$\star$

* hidden options

* casenum

*

* title

100001 'TEST AG'

*

*

* $\quad$ run parameters

* pfss ncases nourp sample

$\begin{array}{lllll}101001 & 2 & 10000000 & 1000 & 1\end{array}$

* idebondp ifacet rbvalue comodel fgmodel idebug

$\begin{array}{lllllll}101002 & 0 & 0 & 1 & 3 & 2 & 0\end{array}$

*

*

* $\quad$ fuel characteristics

* u235enr(\%) ourat curat 


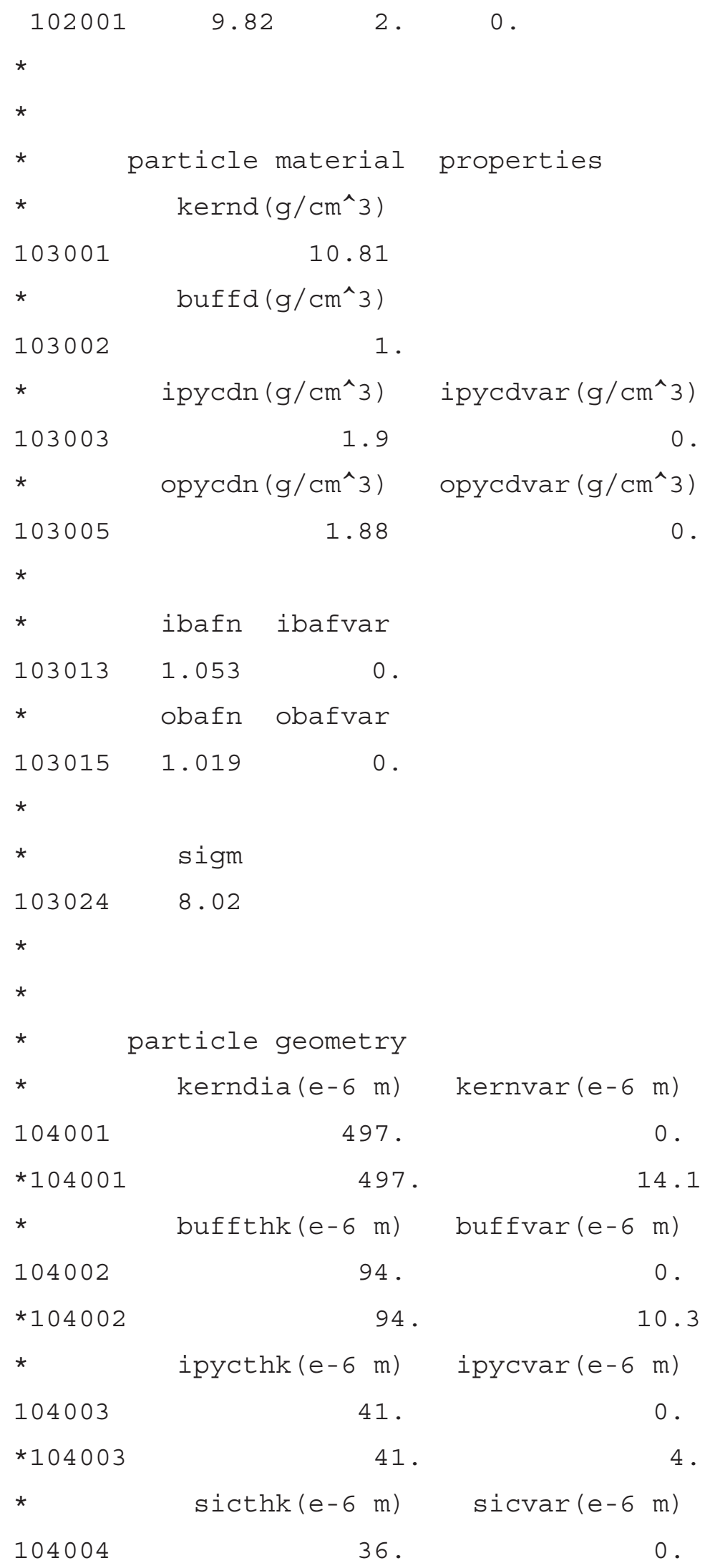




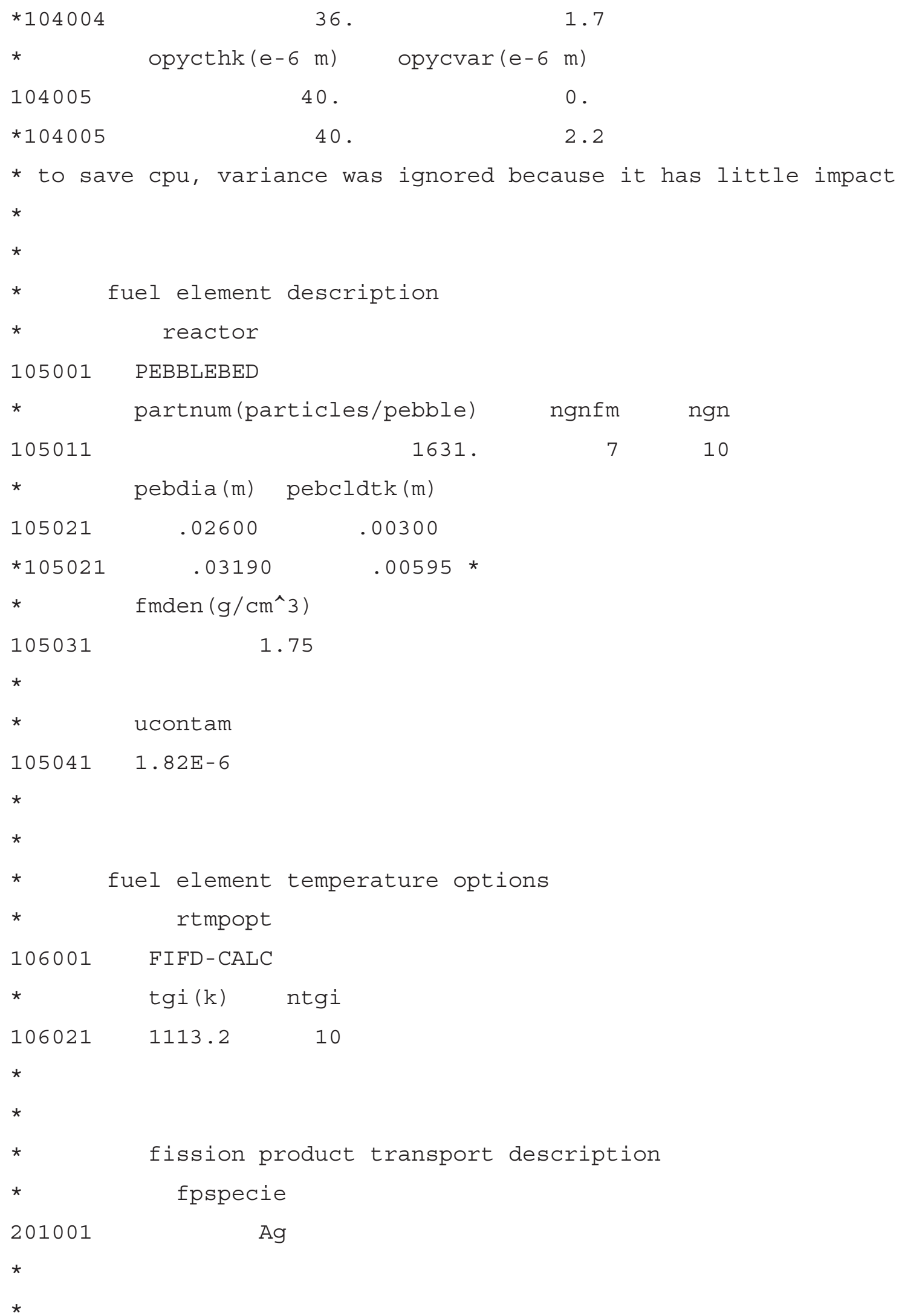




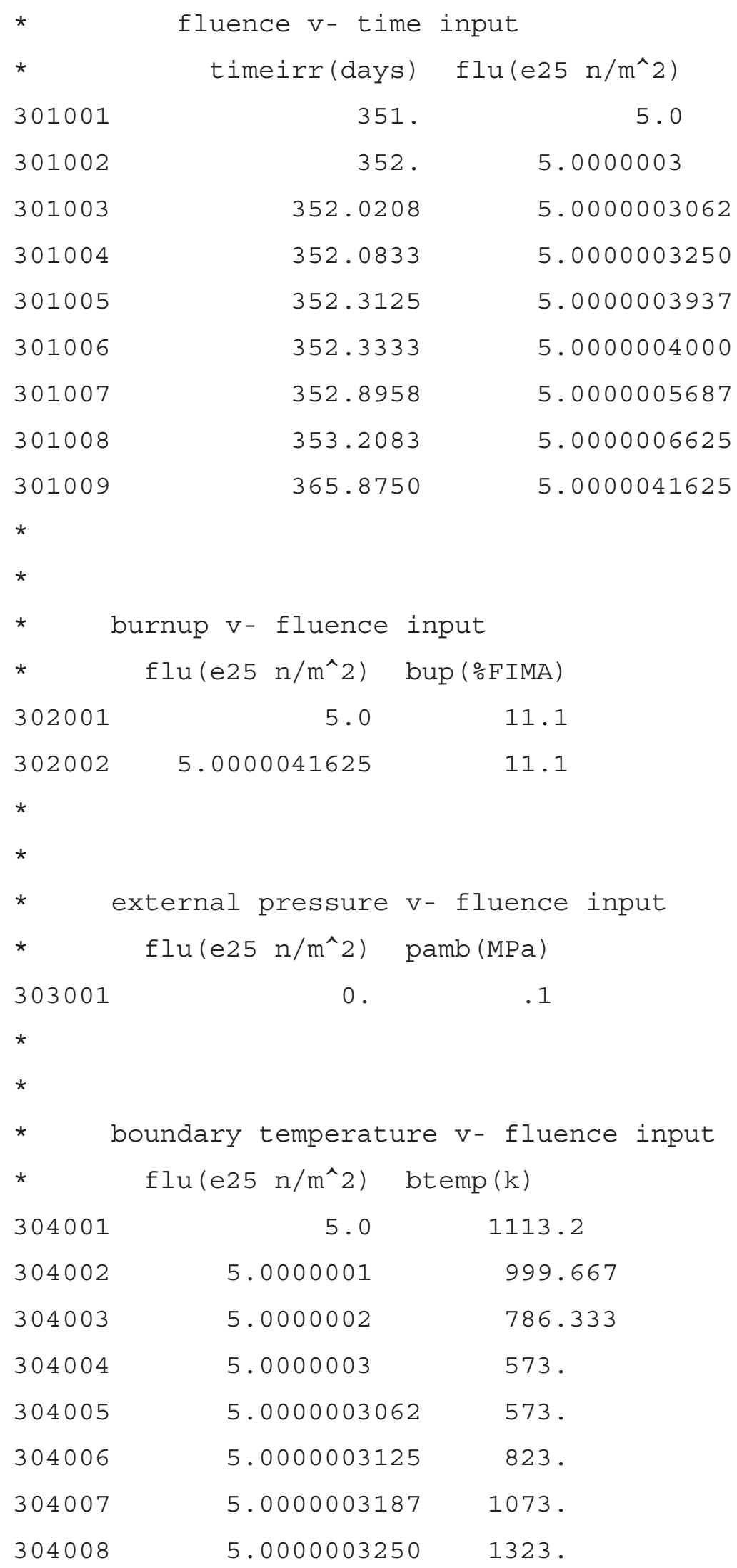




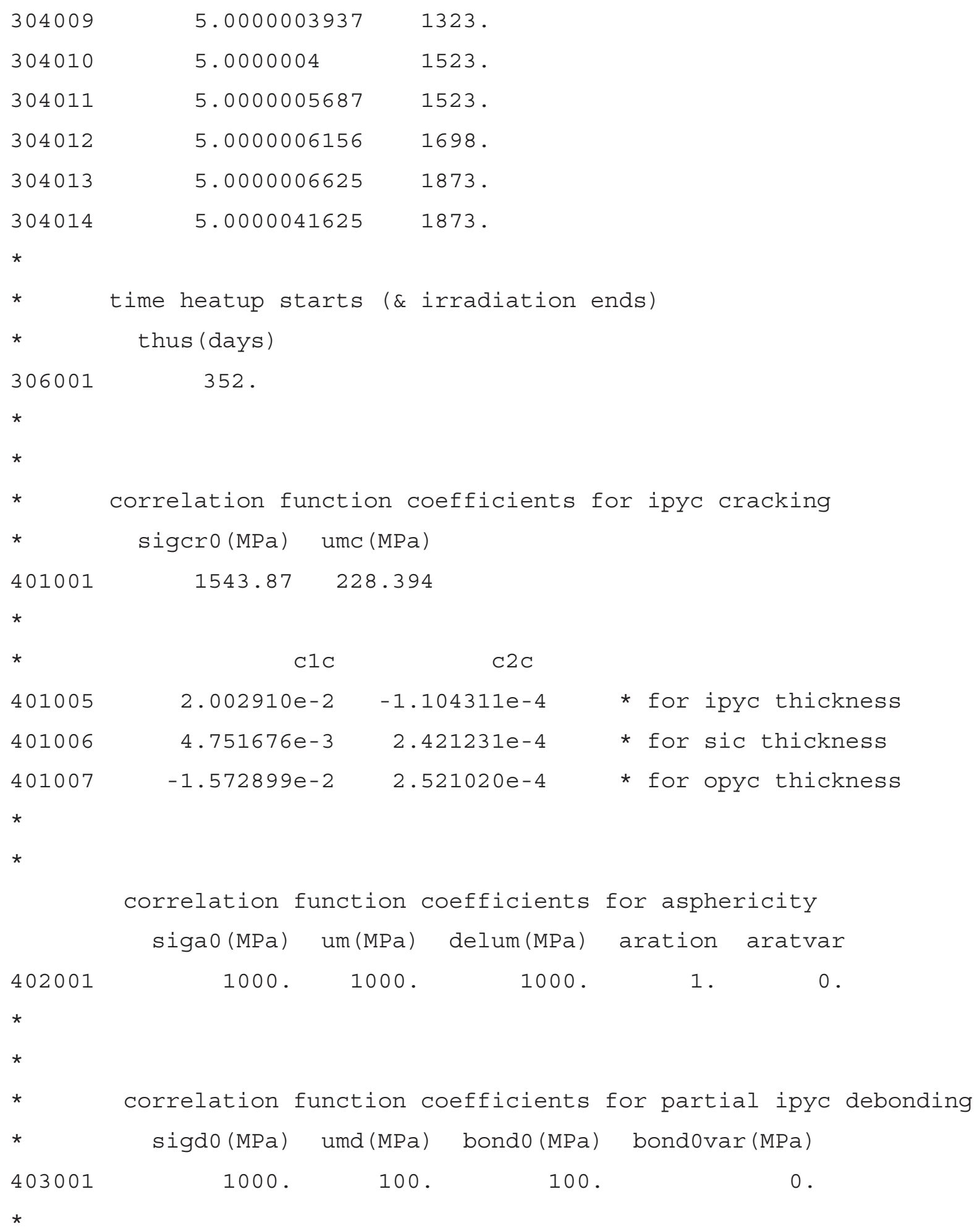




\subsubsection{User Screen Output (prob\#1_.dat)}

hammkd@inl383782: /Documents/PARFUME/user_guide/sample_prob\#1> ./pf.x $12 / 02 / 09$ $07: 53: 58$

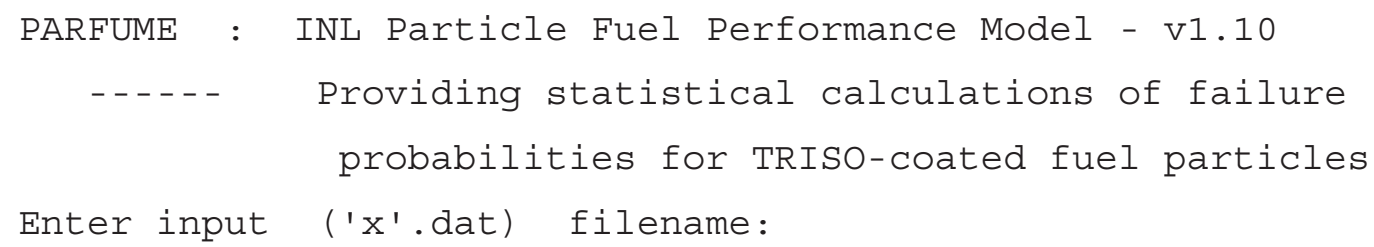




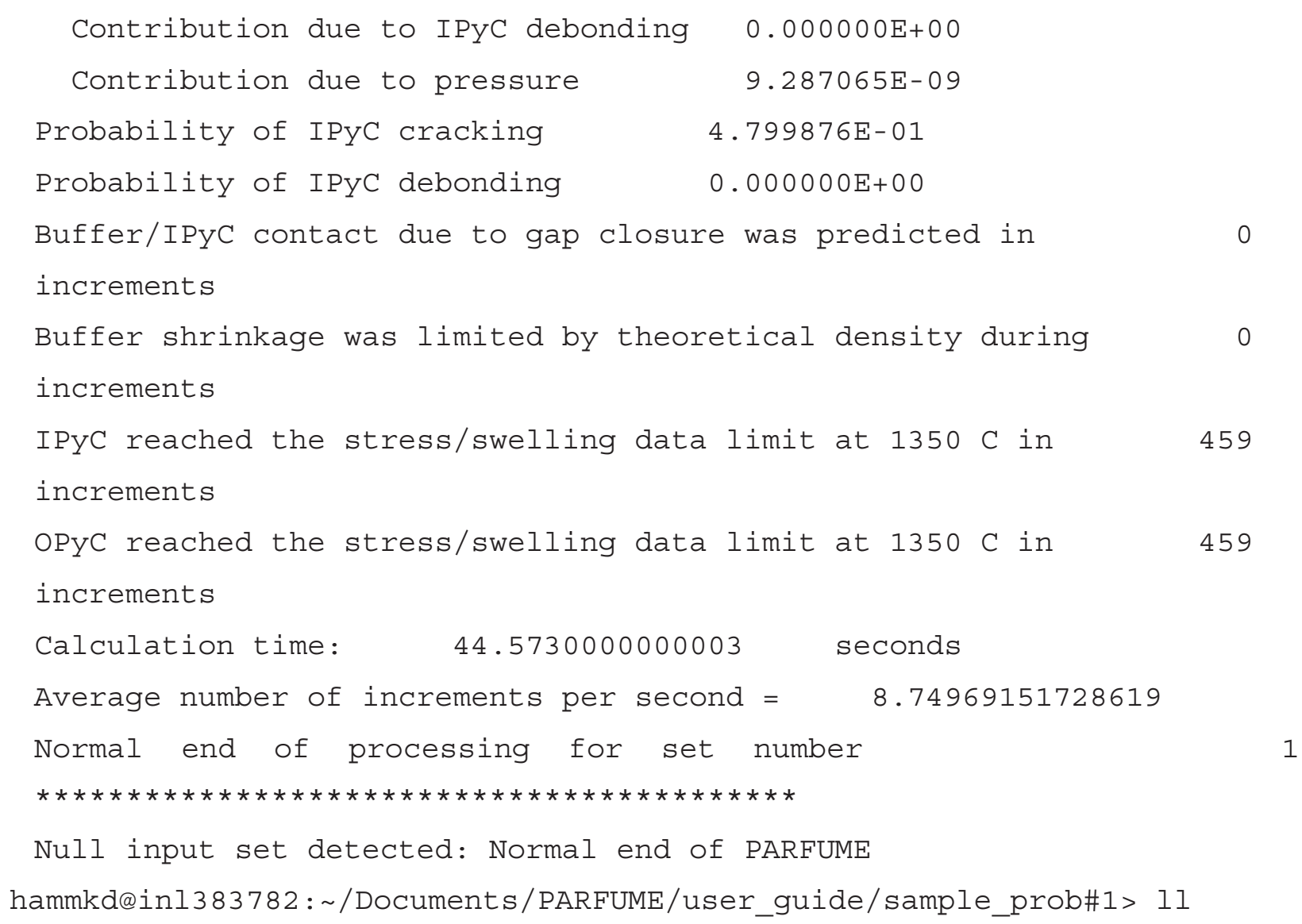

\subsubsection{Screen Output Notes}

1. On the screen output, the word "increments" actually represents integration points; furthermore, the number of integration points represents the number of particles analyzed.

2. Note that the screen output "which requires a total of 390 increments" actually represents 390 integration points (i.e., particles for deterministic analyses, full integration and fast integration). This value is used by code developers to provide an estimate of the number of integration points. The actual number of integration points is 408, specified on the screen output: "IPyC reached the stress/swelling data limit at $1350^{\circ} \mathrm{C}$ in 408 increments."

3. With the variable sample $=1$ (i.e., standard deviation included in analysis), the diffusion model included in the analysis (i.e., fspecie parameter specified), and no user input for any of the input variables having a standard deviation, four variables are specified on the screen output following "Start of multiple integration ..." (i.e., three strength variables: IPyC, SiC, and OPyC and particle radial position in the matrix).

4. With the variable sample $=0$ (i.e., standard deviation not included in analysis) and the diffusion model included in the analysis (i.e., fspecie parameter specified), and no user input for any of the input variables having a standard deviation, three variables are specified on the screen output following "Start of multiple integration ..." (i.e., three strength variables: IPyC, SiC, and OPyC). There is no distribution for the particles; therefore, all particles are at the same radial position in the matrix). 
5. Note that " 11 divisions" represent the maximum number of parts that the normal distribution for variables (such as particle diameter, thickness, density, radial position, BAF, creep amplification) is separated into for the analysis.

6. Note that strength (i.e., IPyC, $\mathrm{SiC}, \mathrm{OPyC}$ ) defaults to being an integration variable when the diffusion model is selected. In this case, the number of integration points is not 11 (unlike the default value of 11 for the other integration points); the number of integration points, which is approximately $4-7$, is determined by a subroutine.

\subsubsection{Output Data (prob\#1_01.res)}

The results from this simulation are presented in graphical form followed by portions of the numerical results, which begin in Section 6.1.5.2.

\subsubsection{Graphical Analysis of Results}

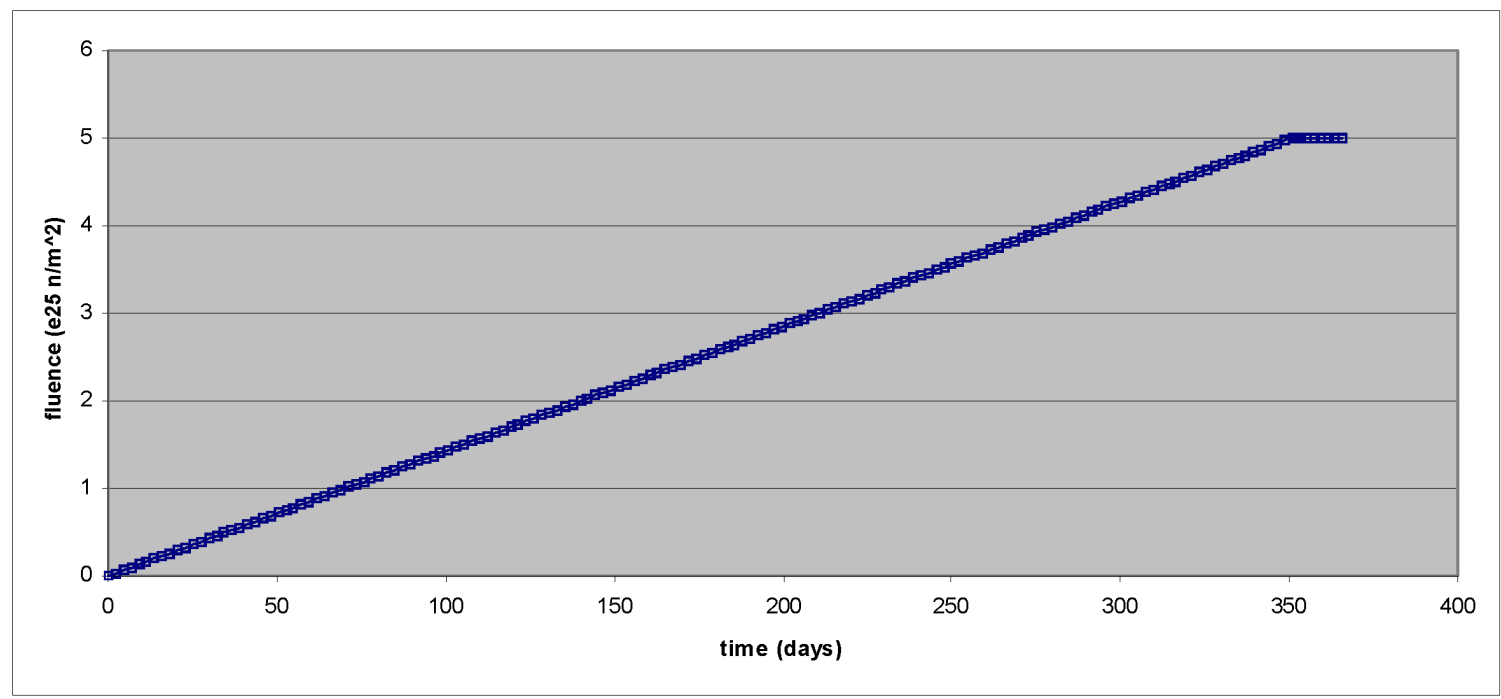

Figure 6-1. Accumulated irradiation history. 


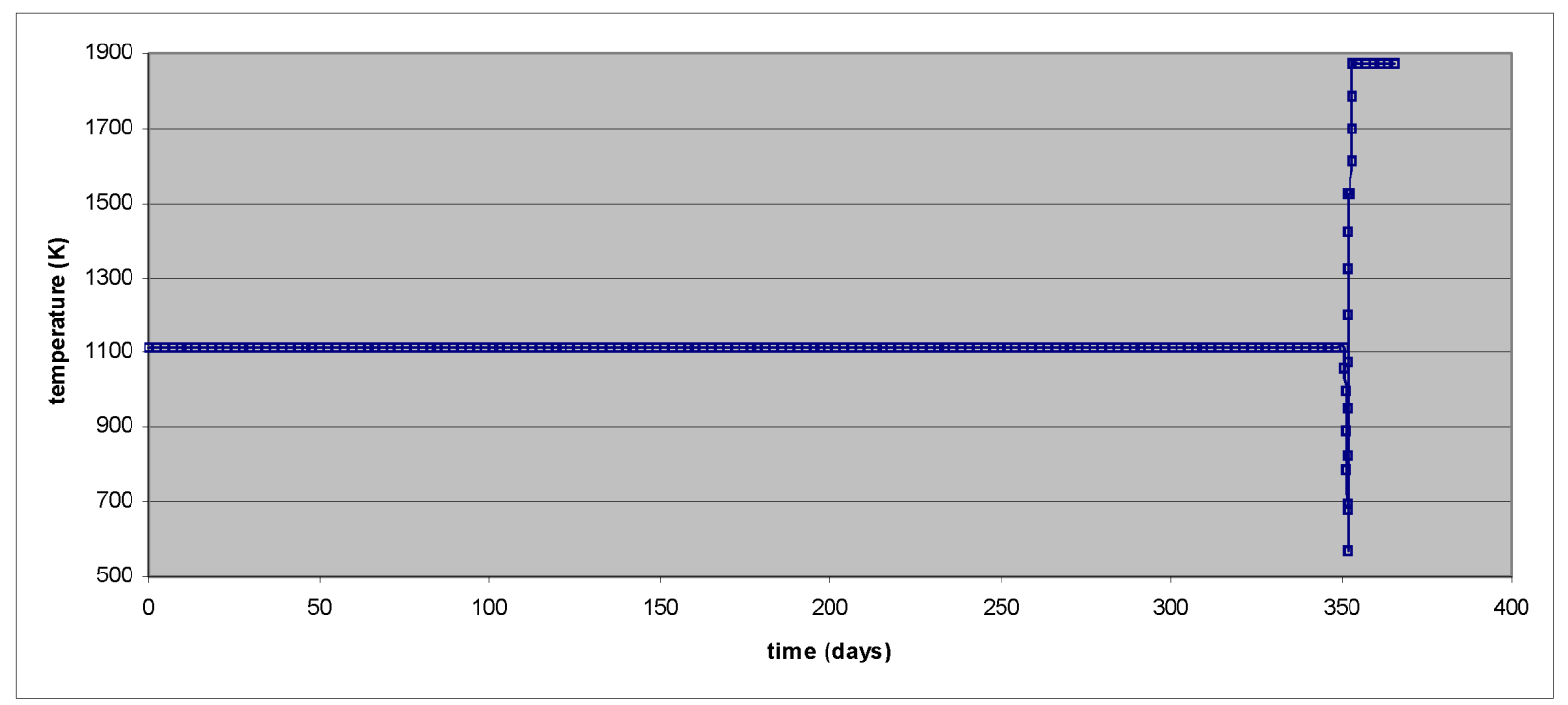

Figure 6-2. Fuel element surface temperature history.

Note that upon removal from the reactor, the fuel element cools prior to heatup in the oven. Additionally, PARFUME does not model the heat generated due to the decay of radioactive nuclides; therefore, the only energy generation occurs as the result of the heat due to the oven.

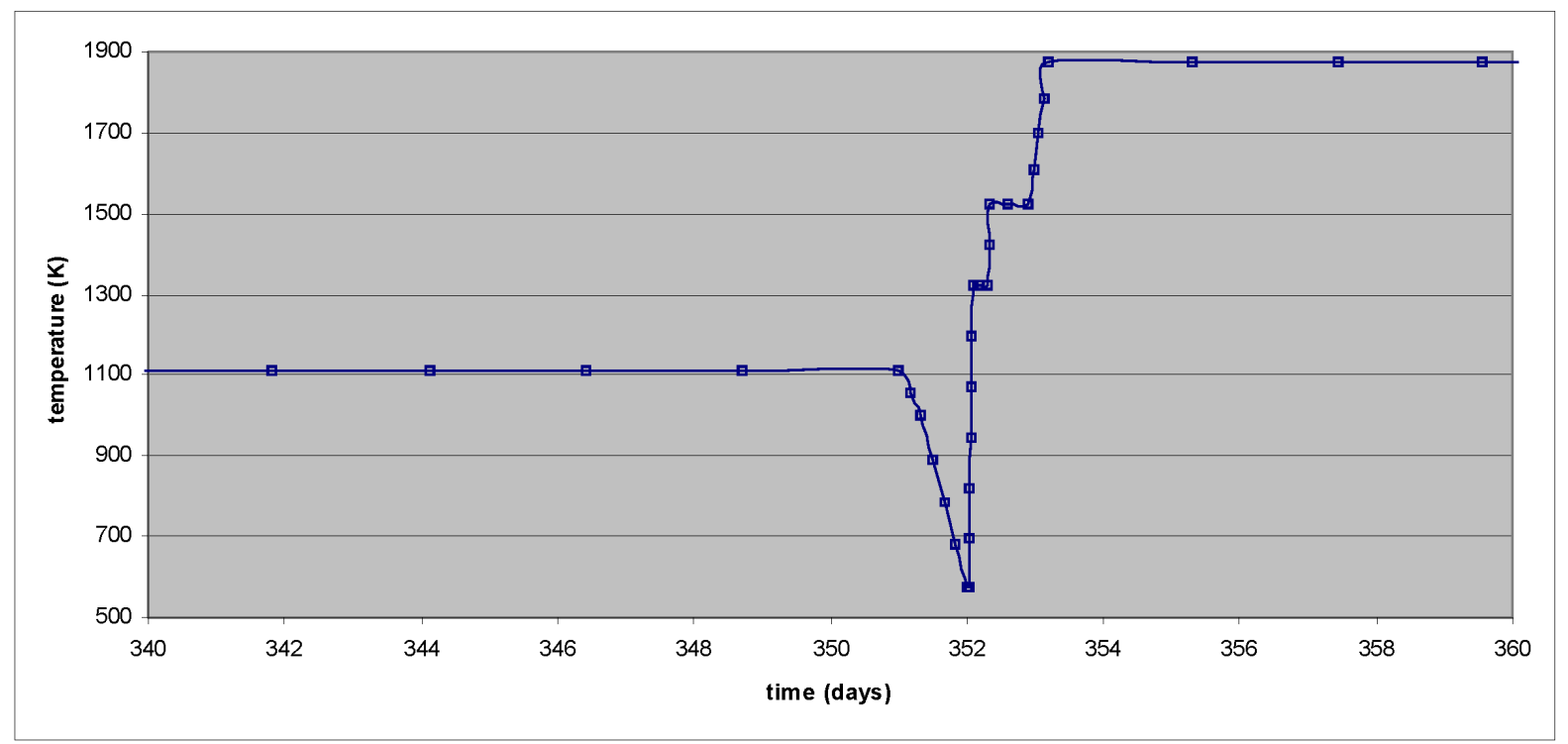

Figure 6-3. Fuel element surface temperature history (heatup). 


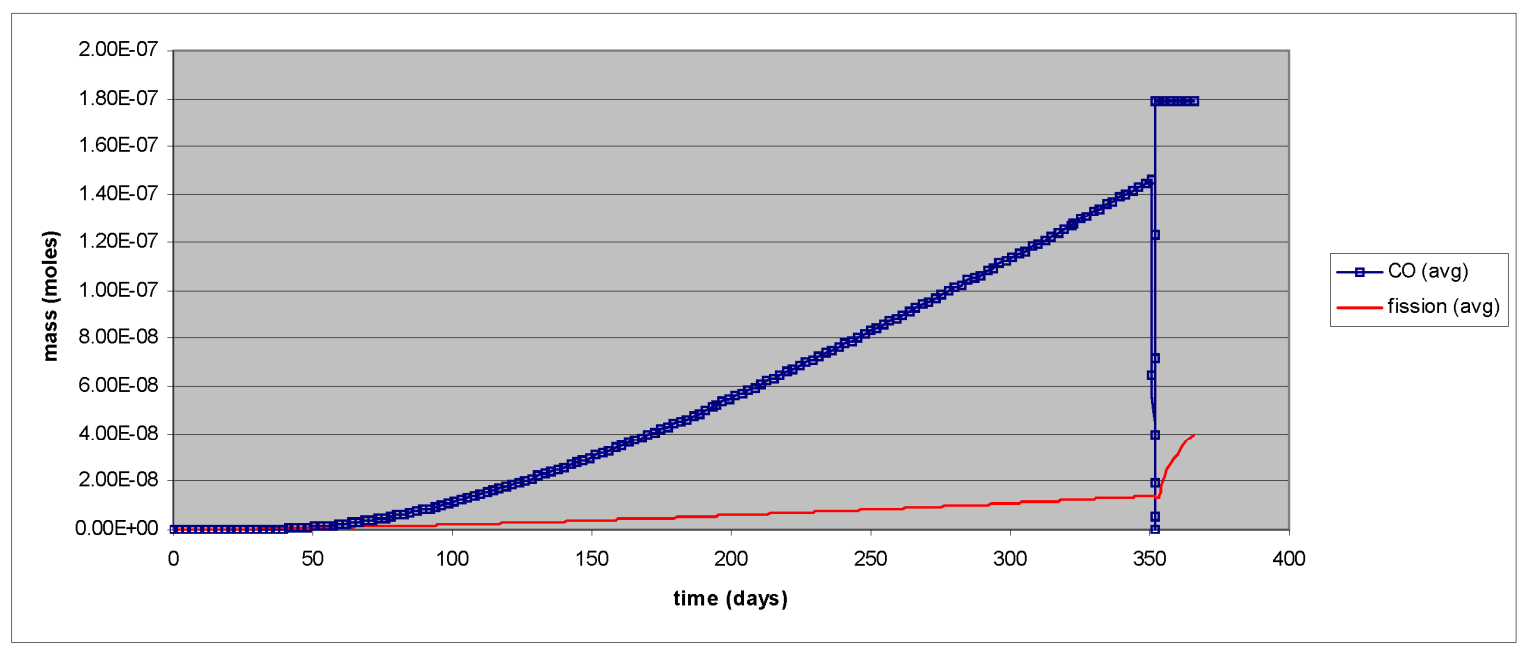

Figure 6-4. Moles of gas produced.

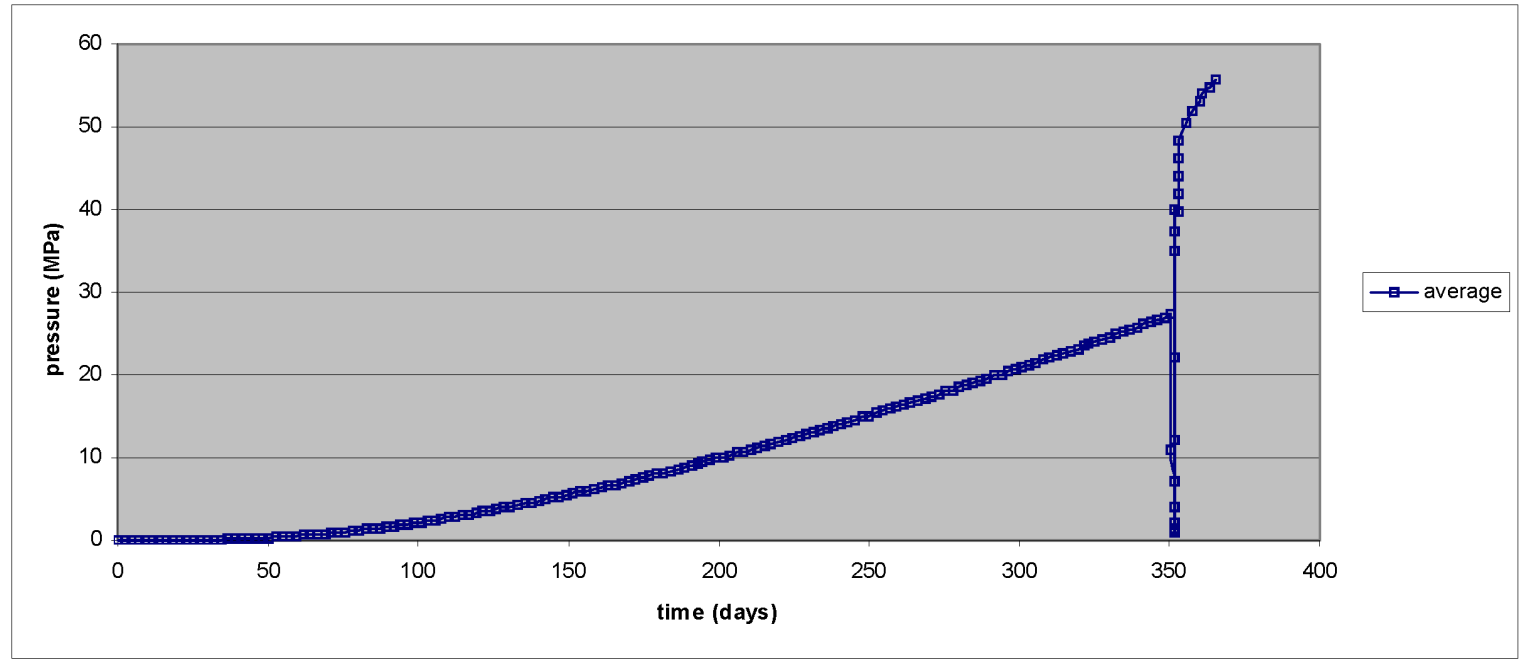

Figure 6-5. Particle internal pressure.

Particle internal pressure buildup due to $\mathrm{CO}$ and FP gas production as shown in Figure 6-4. Note that the increase in pressure at 350 days is due to the particle temperature increase due to heatup in the oven. 


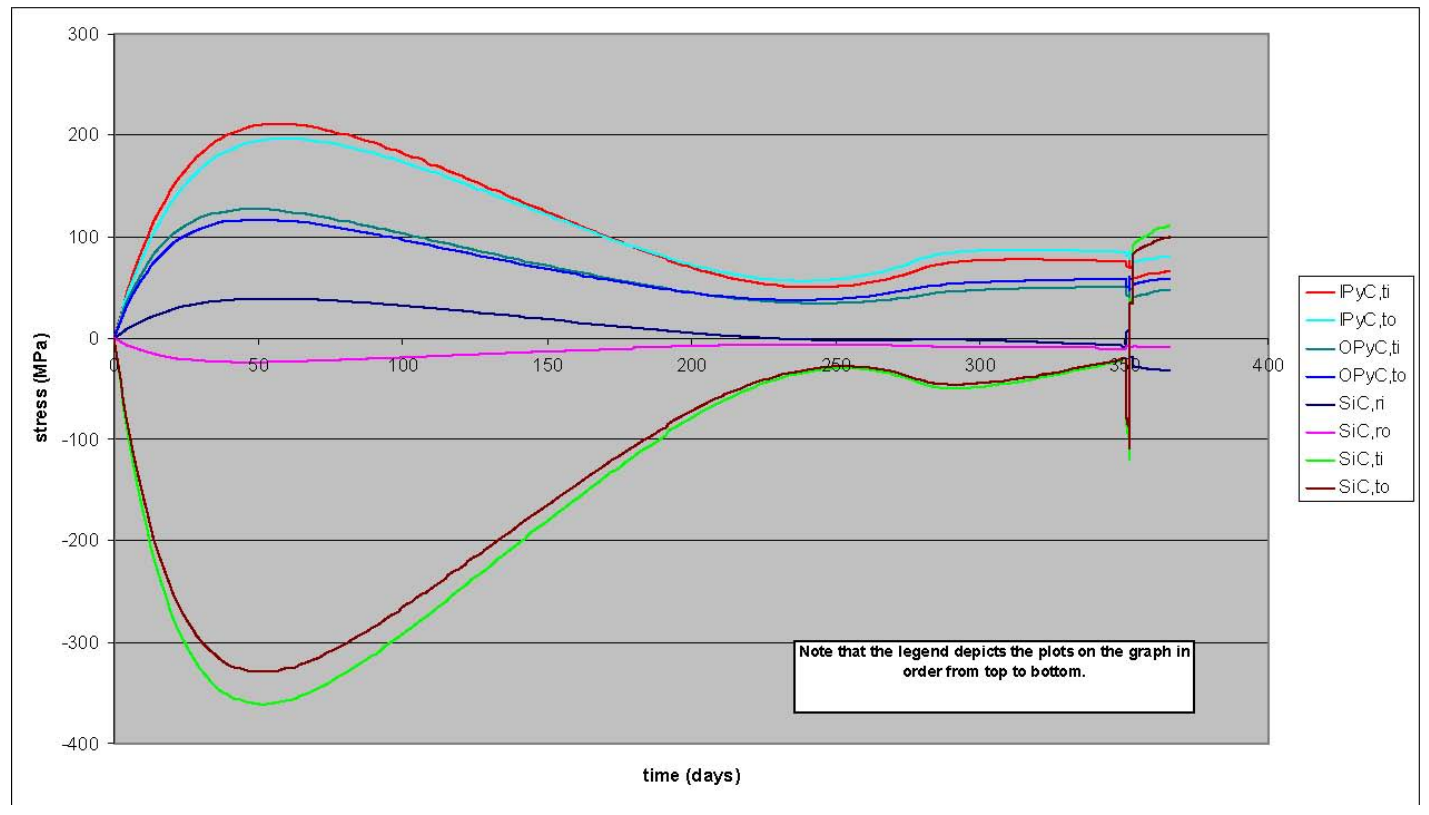

Figure 6-6. Particle nominal stress history.

The IPyC and OPyC layers exhibit shrink and creep due to irradiation; the $\mathrm{SiC}$ remains rigid, experiencing only elastic deformation. In addition, as shown in Figure 6-5, the pressure in the particle gradually increases due to gas buildup. During the first 55 days of irradiation, the magnitude of the stresses increase due to shrinkage of the IPyC and OPyC layers, while the $\mathrm{SiC}$ layer experiences compressive stresses as the result of the OPyC layer shrinking into the $\mathrm{SiC}$ and the IPyC shrinkage away from the $\mathrm{SiC}$ layer. Furthermore, the gradual increase in pressure does not significantly contribute (i.e., offset) the tensile hoop stress in the pyrocarbon layers. As irradiation continues past 55 days, the magnitude of the stresses decreases as the result of material creep. Eventually, the pressure load becomes significant; specifically, the pressure stress counters the $\mathrm{SiC}$ compressive stresses, resulting in a decrease in the magnitude of the $\mathrm{SiC}$ stress. The stress magnitude increases past 350 days due to the increase in fuel element temperature as a result of head addition in the oven. Failure of the particle is expected to occur if the stress in the $\mathrm{SiC}$ layer reaches the $\mathrm{SiC}$ fracture strength. 


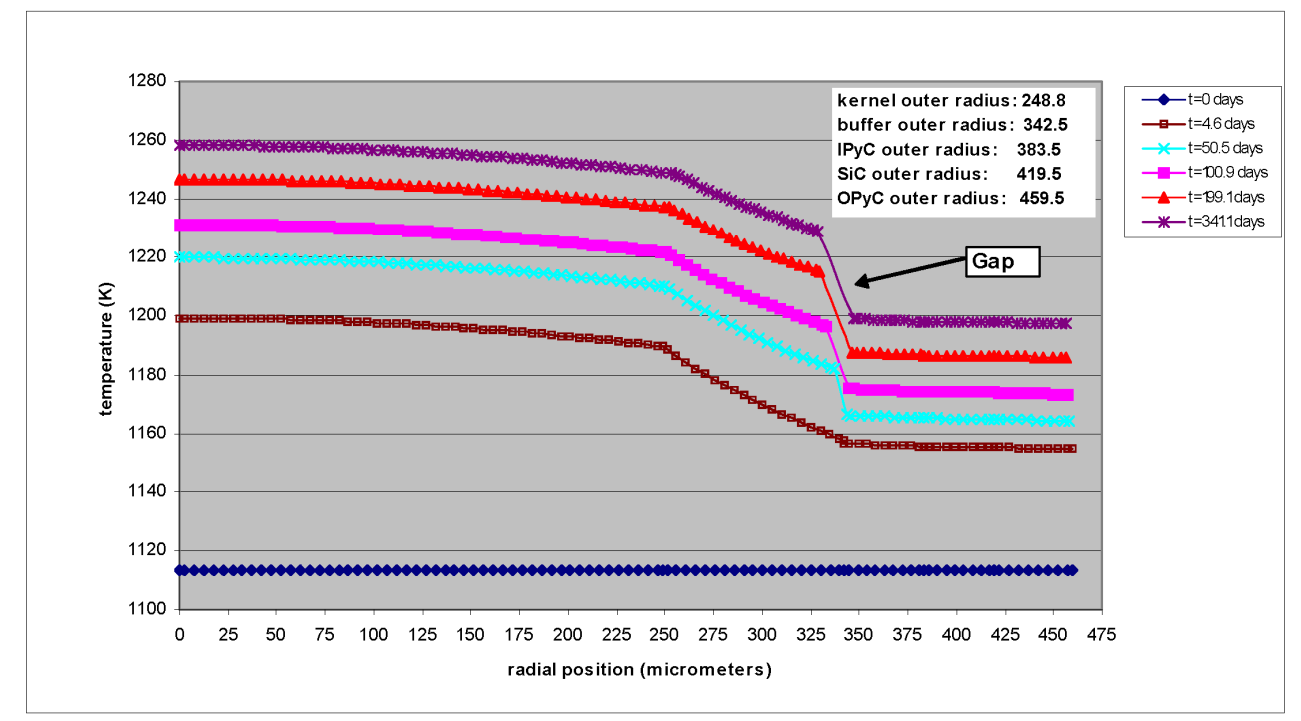

Figure 6-7. Particle radial temperature profile.

As expected, a parabolic temperature gradient occurs in the fuel kernel due to heat generation from fission within the kernel; a linear temperature profile is observed in the buffer due to no energy generation within the buffer. A gap at the interface of the buffer and IPyC layer begins to form at 4.6 days. Since the thermal properties of the $\mathrm{PyC}$ layers and $\mathrm{SiC}$ layer are similar, a large temperature gradient does not develop.

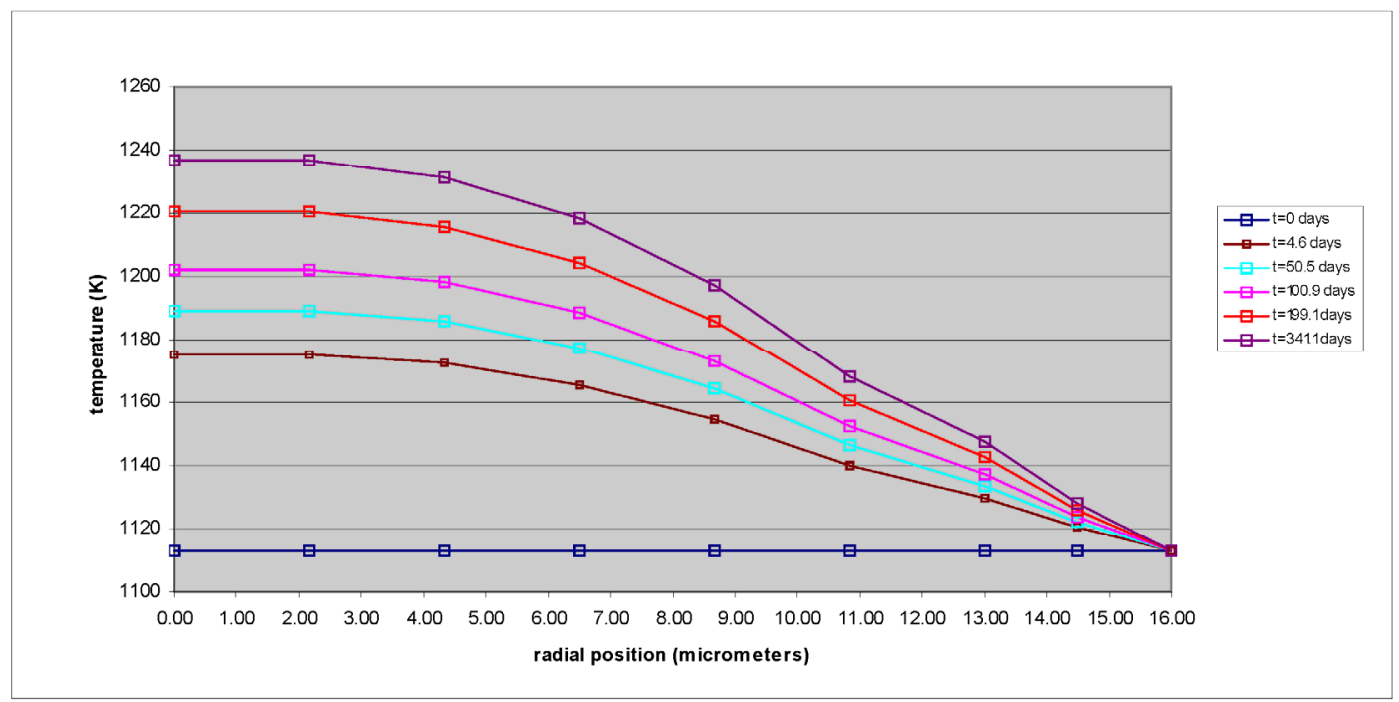

Figure 6-8. Fuel element temperature profile.

As expected, a parabolic temperature gradient occurs in the fueled region of the fuel element due to heat generation from fission. A linear temperature profile develops in the unfueled region. Also note that the user input value for the number of global nodes is 10 ; since the outer node of the fueled region overlaps the inner node of the unfueled region, data associated with only nine nodes is plotted. 


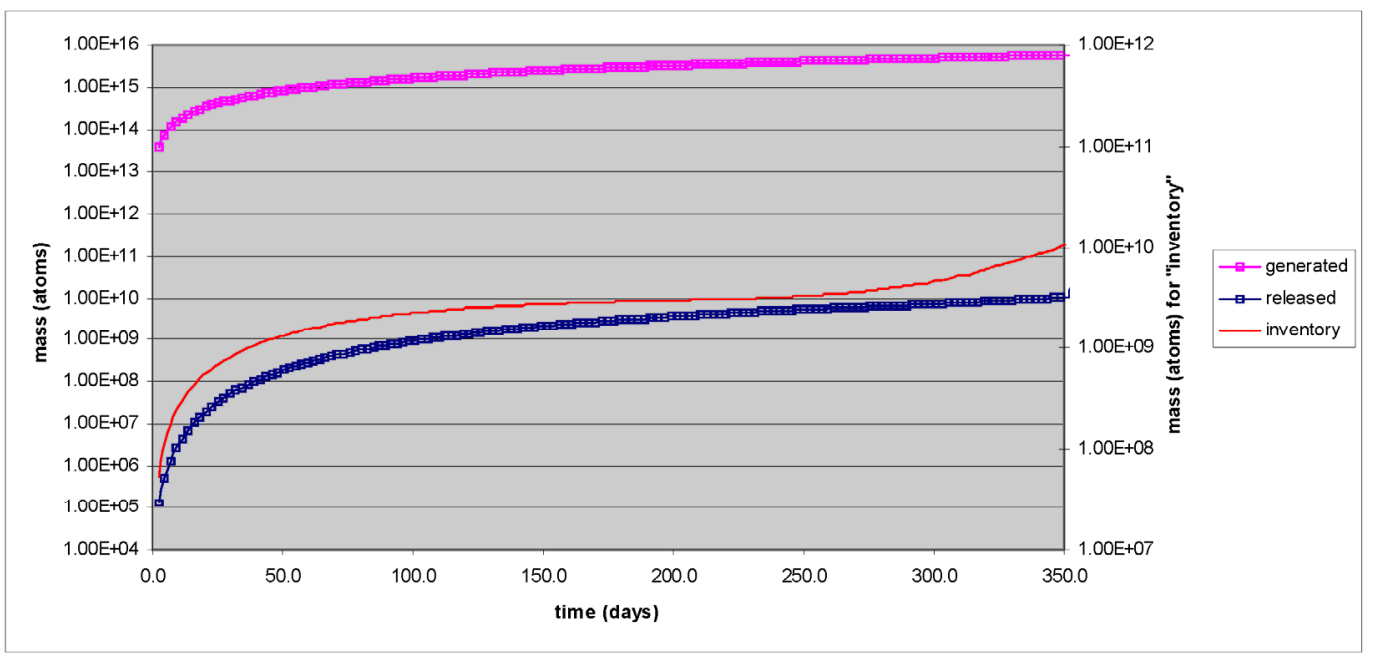

Figure 6-9. "AG" global FP diffusion release history.

The amount of silver $(\mathrm{Ag})$ released as a fraction of $\mathrm{Ag}$ generated increases from $3 \times 10^{-9}$ at 2.3 days to $2 \times 10^{-6}$ after 350 days. Note that the value for "inventory" of $\mathrm{Ag}$ is incorrect.

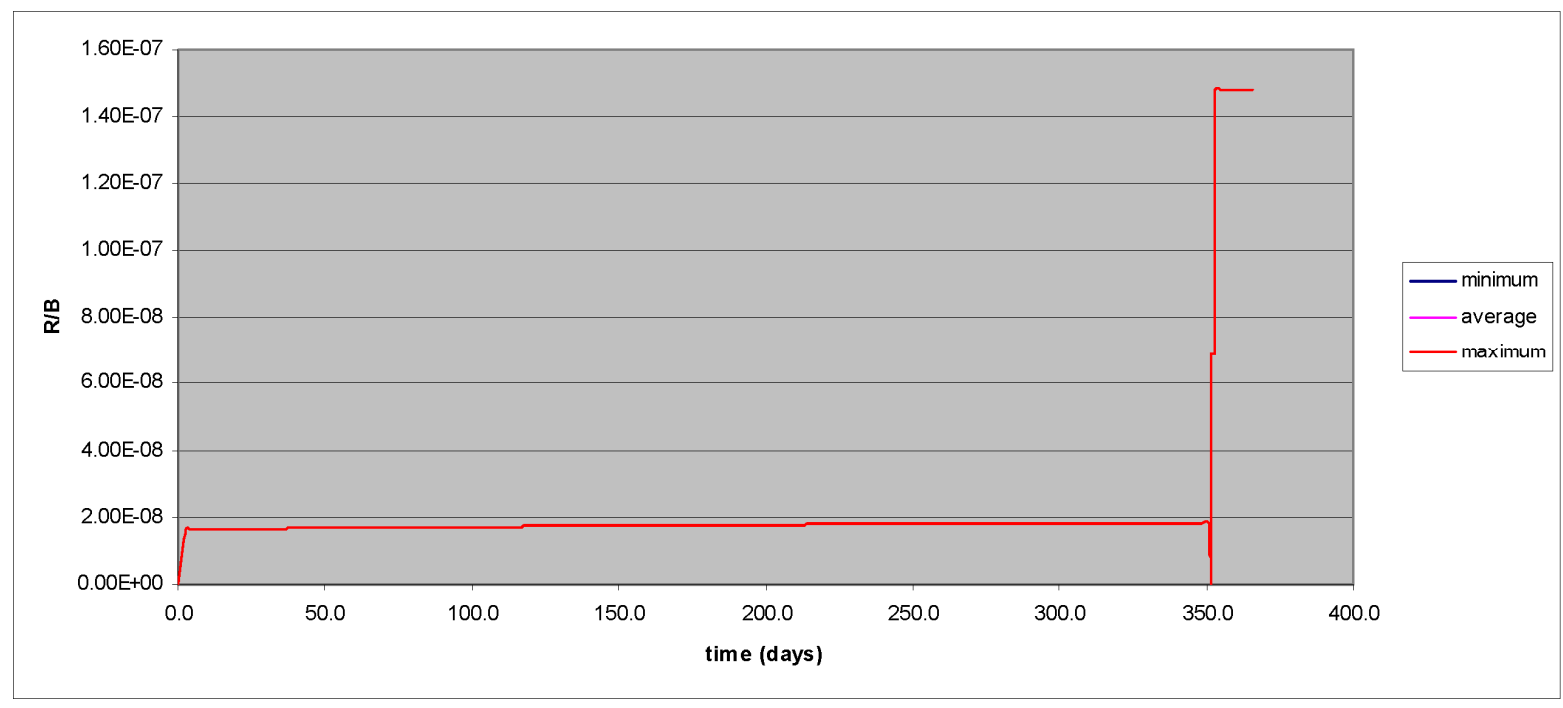

Figure 6-10. Kr-85m release-to-birth ratio. 


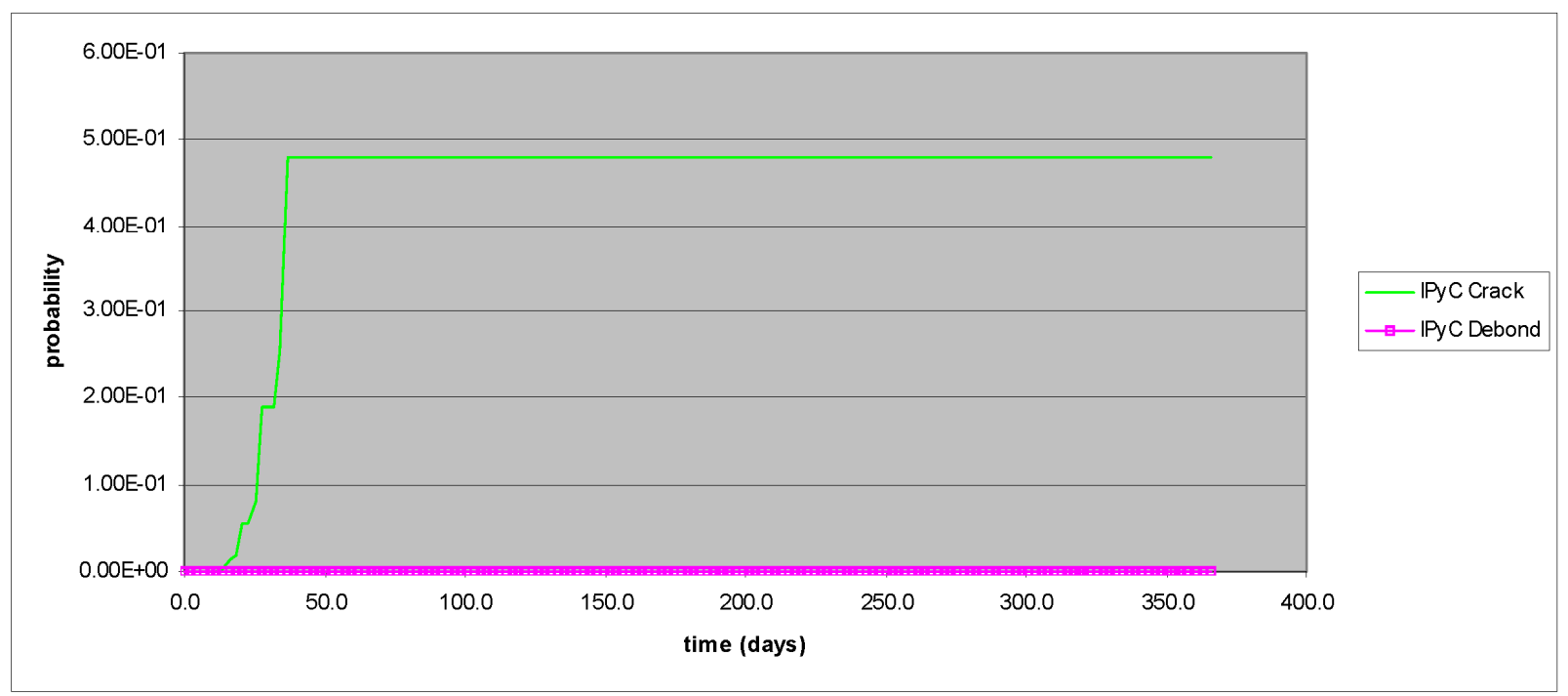

Figure 6-11. IPyC failure probability.

Note that the probability for IPyC failure due to cracking is less than 0.5 , and the probability for IPyC failure due to debonding is 0 since the debonding model was not selected by the user.

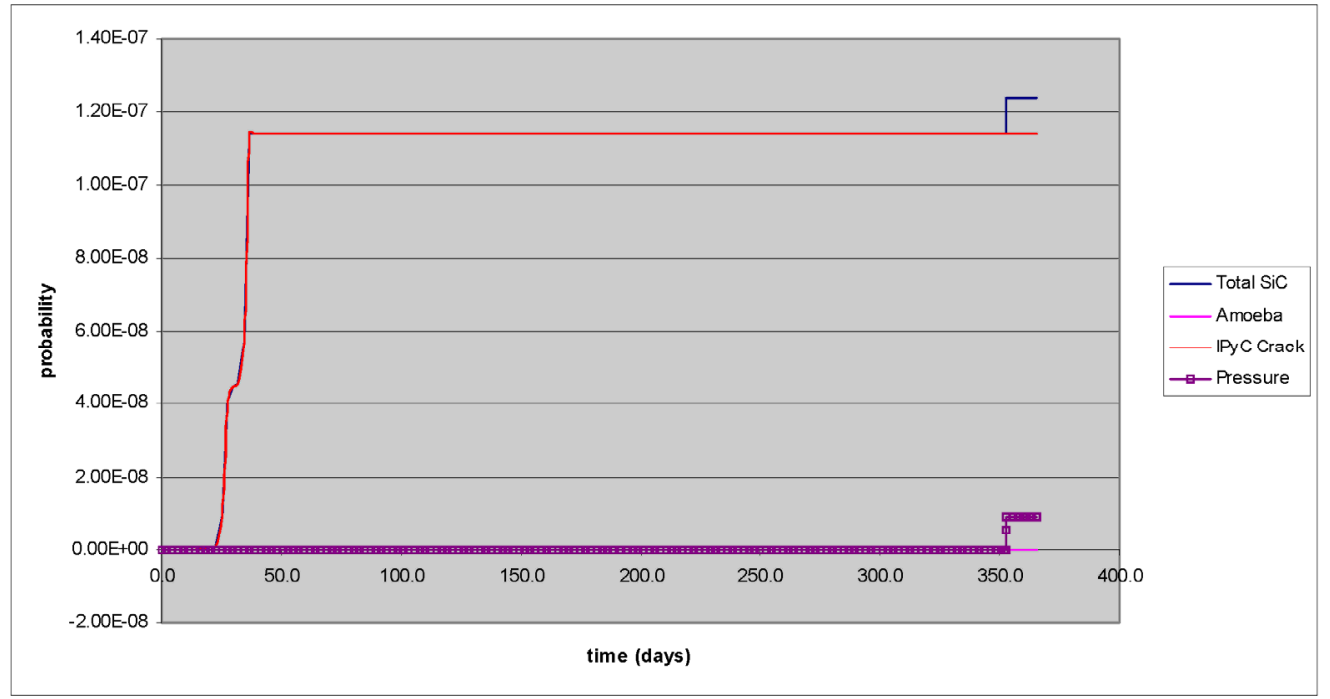

Figure 6-12. $\mathrm{SiC}$ failure probability.

Note that the probability for SiC failure due to cracking of the IPyC is less than $1.2 \mathrm{e}-7$, yet the probability for IPyC failure due to cracking is less than 0.5 (see Figure 6-11). In addition, the increase in failure probability during the first 50 days correlates with the increased stress magnitudes described in Figure 6-6. 


\subsubsection{Numerical Results}

The results are compiled in an output file named "prob\#1_01.res" which includes an input echo, irradiation history derived from input, and the output data such as failure probability, particle and fuel element temperature, and particle internal pressure. The input echo includes the parameter values input by the user and the default parameters, which may not have been included by the user in the input deck. In addition, irradiation history is derived from user input is provided to assist the user in evaluating whether or not the environmental conditions included in the input deck are the expected conditions by the user.

$12 / 02 / 0907: 53: 58$

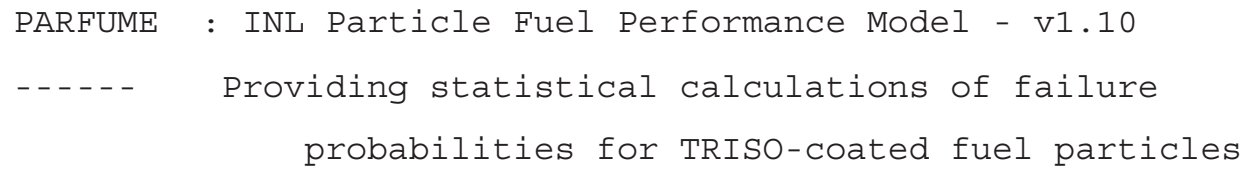

$101001 \quad 2 \quad 10000000 \quad 100 \quad 1$


* CARD 101002 (models)

\begin{tabular}{|c|c|c|c|c|c|c|}
\hline * & idebondp & ifacet & rbvalue & comodel & fgmodel & idebug \\
\hline 101002 & 0 & 0 & 1 & 3 & 2 & 0 \\
\hline
\end{tabular}

*

$* * * * * * * * * * * * * * * * * * * * *$ MATERIAL PROPERTIES

* CARD 101002 (fuel characteristics)

* u235enr(\%) ourat curat

$\begin{array}{llll}102001 & 9.82 & 2 .\end{array}$

*

* CARD 103001 (kernel properties)

* $\quad \operatorname{kernd}\left(\mathrm{g} / \mathrm{cm}^{\wedge} 3\right) \operatorname{kernt}\left(\mathrm{g} / \mathrm{cm}^{\wedge} 3\right)$

$103001 \quad 10.81$

* CARD 103002 (buffer properties)

* $\quad$ buffa $\left(\mathrm{g} / \mathrm{cm}^{\wedge} 3\right)$ bufft $\left(\mathrm{g} / \mathrm{cm}^{\wedge} 3\right)$

$103002 \quad 1$

* CARD 103003 (IPyC properties)

* $\quad$ ipycdn $\left(\mathrm{g} / \mathrm{cm}^{\wedge} 3\right)$ ipycdvar $\left(\mathrm{g} / \mathrm{cm}^{\wedge} 3\right)$

$103003 \quad 1.90$.

* cARD 103005 (OPyC properties)

* opycdn $\left(\mathrm{g} / \mathrm{cm}^{\wedge} 3\right) \operatorname{opycdvar}\left(\mathrm{g} / \mathrm{cm}^{\wedge} 3\right)$

$\begin{array}{lll}103005 & 1.88 & 0\end{array}$

$\star$

* CARD 103013 (IPyC Bacon anisotropic factor)

* $\quad$ ibafn ibafvar

$103013 \quad 1.053 \quad 0$.

* card 103015 (OPyC Bacon anisotropic factor)

* obafn obafvar

10301501.0190.

$\star$

* CARD 103023 (IPyC Weibull modulus)

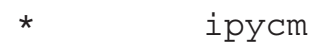

1030239.50

* cARD 103024 (SiC Weibull modulus)

* $\quad$ sigm 


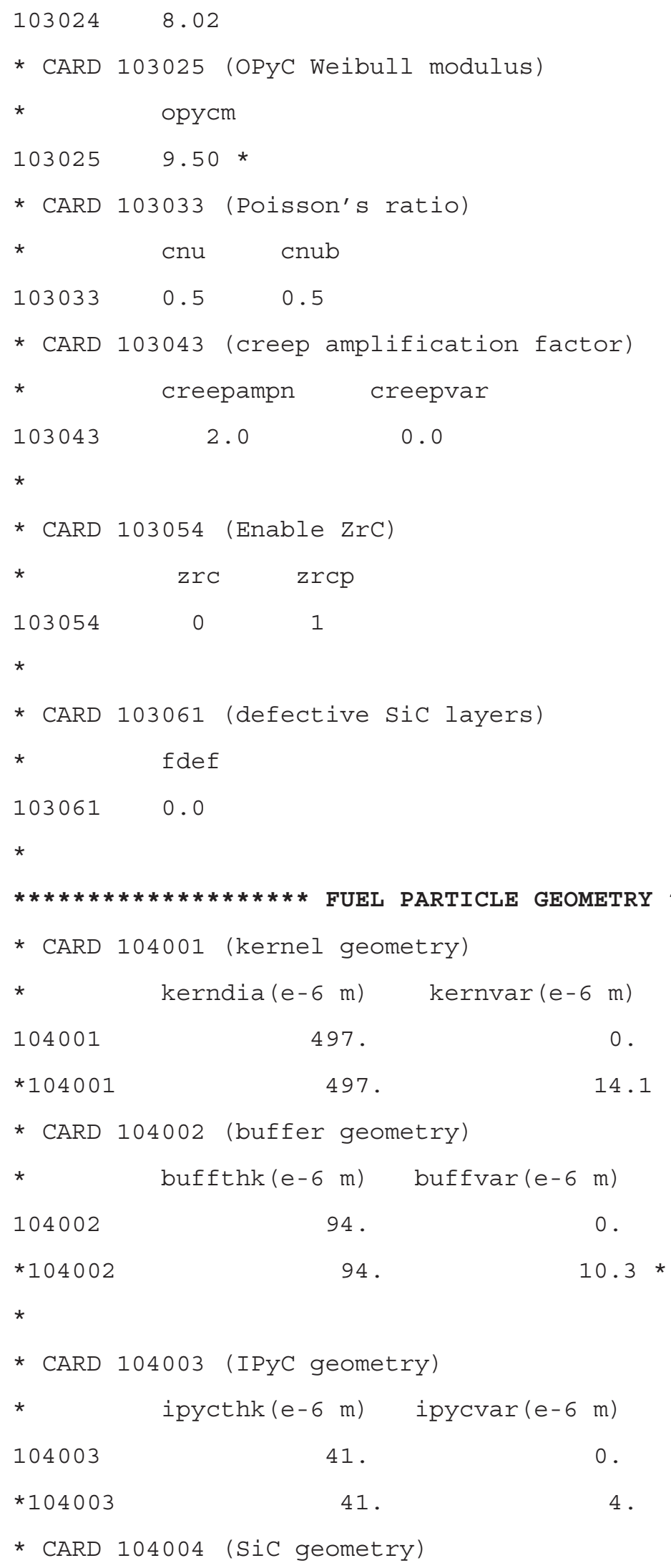




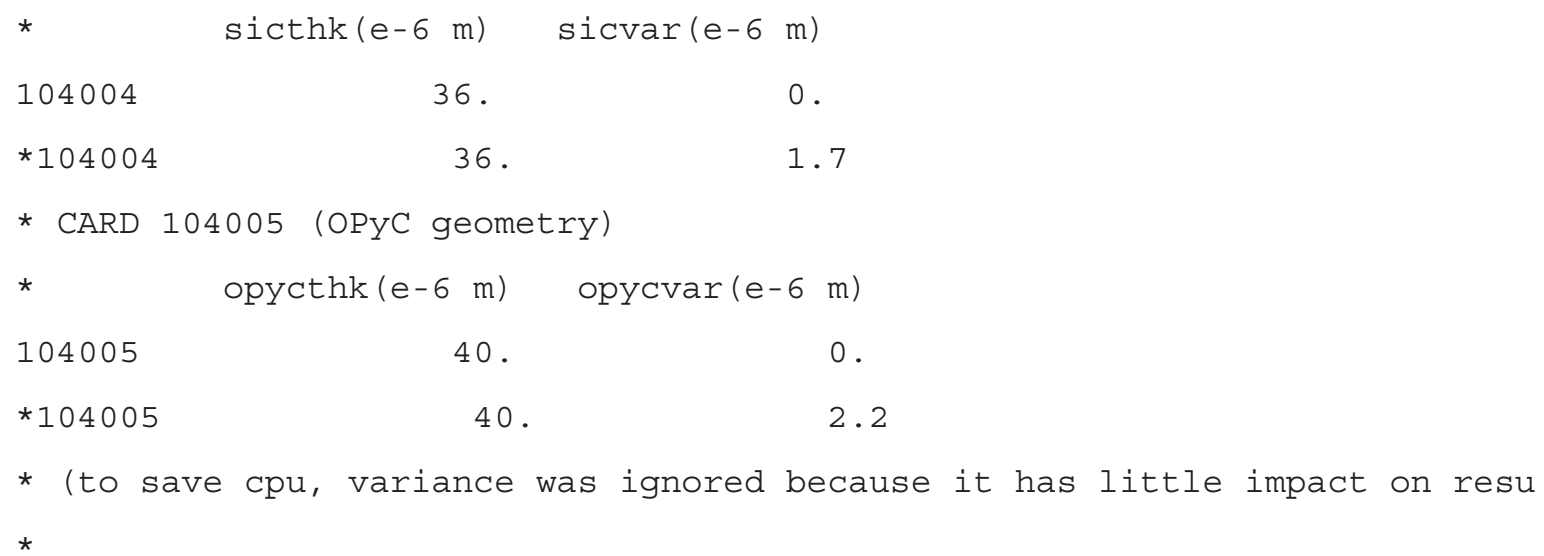




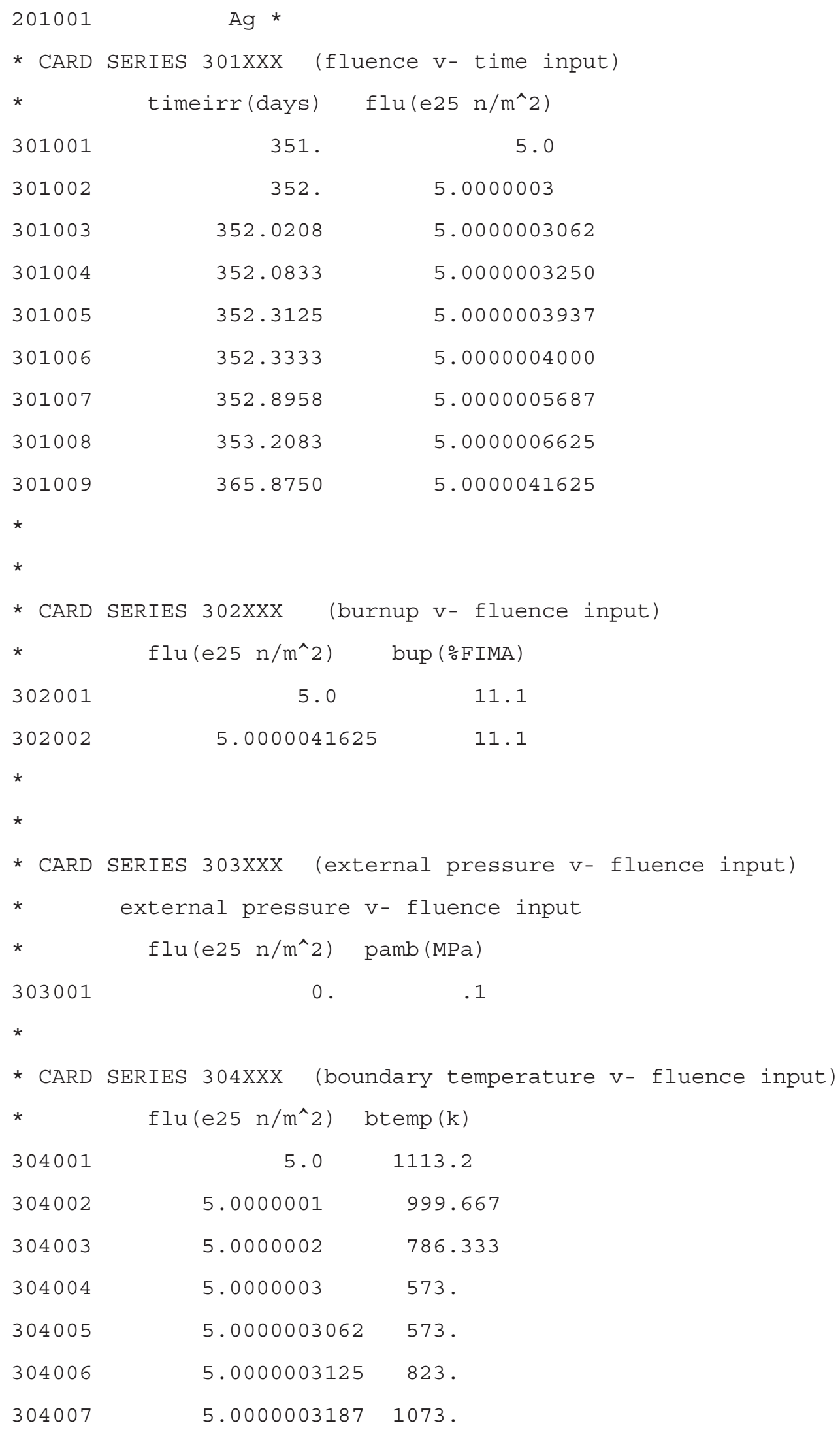




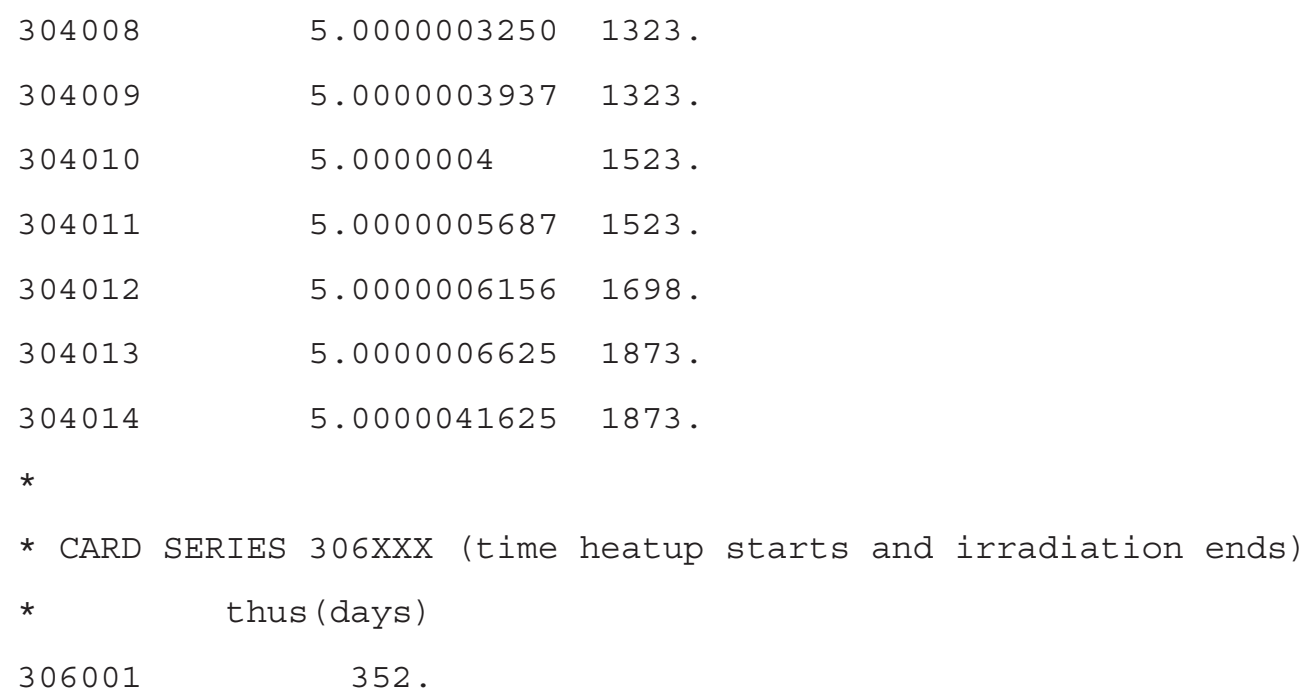




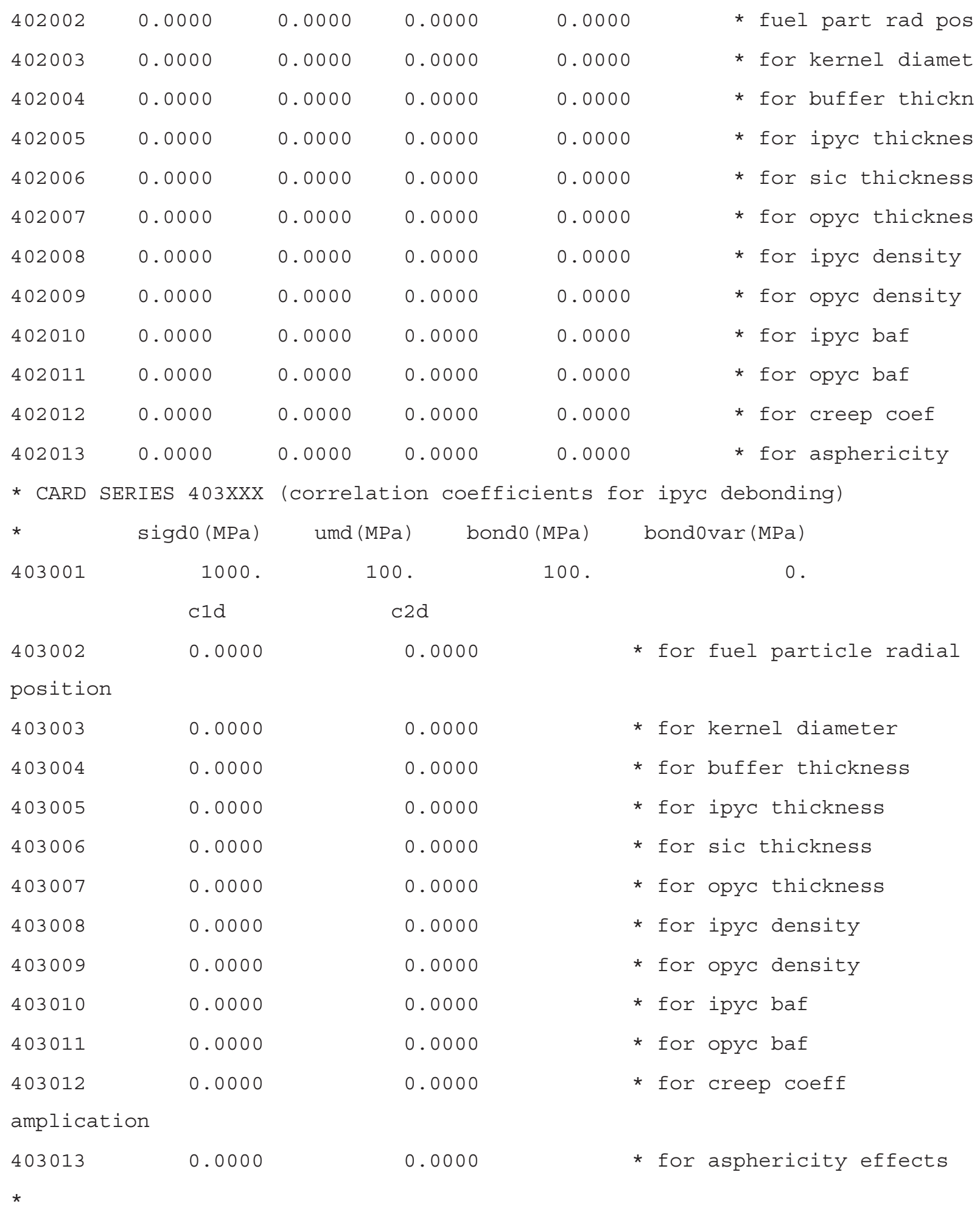


Input after processing

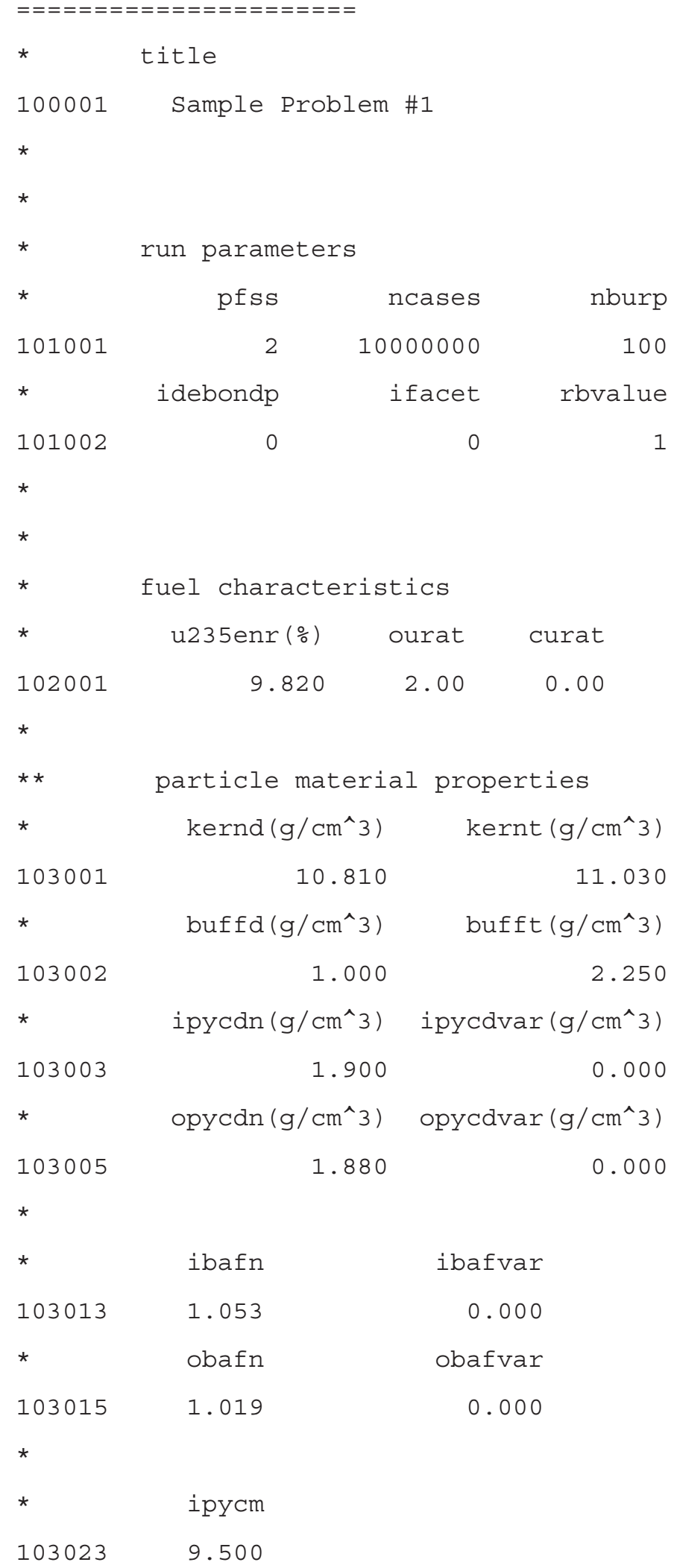

$\begin{array}{rrr}\text { u235enr }(\%) & \text { ourat } & \text { curat } \\ 9.820 & 2.00 & 0.00\end{array}$

particle material properties $\operatorname{kernd}\left(\mathrm{g} / \mathrm{cm}^{\wedge} 3\right) \quad \operatorname{kernt}\left(\mathrm{g} / \mathrm{cm}^{\wedge} 3\right)$

10.810

11.030

buffd $\left(\mathrm{g} / \mathrm{cm}^{\wedge} 3\right)$ bufft $\left(\mathrm{g} / \mathrm{cm}^{\wedge} 3\right)$

$$
1.000 \quad 2.250
$$

ipycdn $\left(\mathrm{g} / \mathrm{cm}^{\wedge} 3\right)$ ipycdvar $\left(\mathrm{g} / \mathrm{cm}^{\wedge} 3\right)$

$$
\begin{array}{ll}
1.900 & 0.000
\end{array}
$$

$\operatorname{opycdn}\left(\mathrm{g} / \mathrm{cm}^{\wedge} 3\right) \quad \operatorname{opycdvar}\left(\mathrm{g} / \mathrm{cm}^{\wedge} 3\right)$
1.880
0.000 


\begin{tabular}{|c|c|c|}
\hline * & sigm & \\
\hline 103024 & 8.020 & \\
\hline * & opycm & \\
\hline 103025 & 9.500 & \\
\hline * & & \\
\hline * & cnu & cnub \\
\hline 103033 & 0.500 & 0.500 \\
\hline * & & \\
\hline * & creepampn & creepvar \\
\hline 103043 & 2.00 & 0.00 \\
\hline * & & \\
\hline * & $\operatorname{zrc}$ & $\mathrm{zrcp}$ \\
\hline 103054 & 0 & 1 \\
\hline
\end{tabular}

*

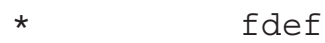

$103061 \quad 0.00$

* *

$\star$

$\star$

104001

*

104002

*

104003

*

104004

*

104005

* *

$\star$

*

*

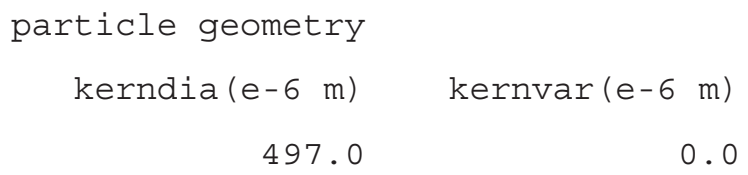

0.0
105001

105011

*

fuel matrix description

reactor

PEBBLEBED

\begin{abstract}
partnum (particles/pebble)
\end{abstract}
1. $63 \mathrm{E}+03$ ngn

$7 \quad 10$ 


\begin{tabular}{|c|c|c|}
\hline * & pebdia (m) & cldtk (m) \\
\hline 105021 & 0.026 & 0.0030 \\
\hline * & & \\
\hline * & fmden $\left(\mathrm{g} / \mathrm{cm}^{\wedge} 3\right)$ & \\
\hline 105031 & 1.75 & \\
\hline * & & \\
\hline * & ucontam & \\
\hline 105041 & $1.820 \mathrm{E}-06$ & \\
\hline * & & \\
\hline * * & fuel matrix tempera & ature options \\
\hline * & rtmpopt & \\
\hline 106001 & FIFD-CALC * & \\
\hline * & & \\
\hline * & initial fuel matrix & temperatures \\
\hline * & temperature $(\mathrm{k})$ & node \\
\hline & 1113.20 & 1 \\
\hline & 1113.20 & 2 \\
\hline & 1113.20 & 3 \\
\hline & 1113.20 & 4 \\
\hline & 1113.20 & 5 \\
\hline & 1113.20 & 6 \\
\hline & 1113.20 & 7 \\
\hline & 1113.20 & 8 \\
\hline & 1113.20 & 9 \\
\hline & 1113.20 & 10 \\
\hline
\end{tabular}

* 
* irradiation history derived from input

\begin{tabular}{|c|c|c|c|c|c|}
\hline & & flut & bupt & xprest & \\
\hline *step & ttime (days) & $\left(\mathrm{e} 25 \mathrm{n} / \mathrm{m}^{\wedge} 2, \mathrm{E}>.18 \mathrm{MeV}\right)$ & ( $\%$ FIMA) & $(\mathrm{mps})$ & btempt $(\mathrm{k})$ \\
\hline 1 & 0.000 & 0.000 & 0.000 & 0.100 & 1113.200 \\
\hline 2 & 2.294 & 0.033 & 0.073 & 0.100 & 1113.200 \\
\hline 3 & 4.588 & 0.065 & 0.145 & 0.100 & 1113.200 \\
\hline 4 & 6.882 & 0.098 & 0.218 & 0.100 & 1113.200 \\
\hline 5 & 9.176 & 0.131 & 0.290 & 0.100 & 1113.200 \\
\hline 6 & 11.471 & 0.163 & 0.363 & 0.100 & 1113.200 \\
\hline 7 & 13.765 & 0.196 & 0.435 & 0.100 & 1113.200 \\
\hline 8 & 16.059 & 0.229 & 0.508 & 0.100 & 1113.200 \\
\hline 9 & 18.353 & 0.261 & 0.580 & 0.100 & 1113.200 \\
\hline 10 & 20.647 & 0.294 & 0.653 & 0.100 & 1113.200 \\
\hline 11 & 22.941 & 0.327 & 0.725 & 0.100 & 1113.200 \\
\hline 12 & 25.235 & 0.359 & 0.798 & 0.100 & 1113.200 \\
\hline 13 & 27.529 & 0.392 & 0.871 & 0.100 & 1113.200 \\
\hline 14 & 29.824 & 0.425 & 0.943 & 0.100 & 1113.200 \\
\hline 15 & 32.118 & 0.458 & 1.016 & 0.100 & 1113.200 \\
\hline 16 & 34.412 & 0.490 & 1.088 & 0.100 & 1113.200 \\
\hline 17 & 36.706 & 0.523 & 1.161 & 0.100 & 1113.200 \\
\hline 18 & 39.000 & 0.556 & 1.233 & 0.100 & 1113.200 \\
\hline 19 & 41.294 & 0.588 & 1.306 & 0.100 & 1113.200 \\
\hline 20 & 43.588 & 0.621 & 1.378 & 0.100 & 1113.200 \\
\hline 21 & 45.882 & 0.654 & 1.451 & 0.100 & 1113.200 \\
\hline 22 & 48.176 & 0.686 & 1.524 & 0.100 & 1113.200 \\
\hline 23 & 50.471 & 0.719 & 1.596 & 0.100 & 1113.200 \\
\hline 24 & 52.765 & 0.752 & 1.669 & 0.100 & 1113.200 \\
\hline 25 & 55.059 & 0.784 & 1.741 & 0.100 & 1113.200 \\
\hline 26 & 57.353 & 0.817 & 1.814 & 0.100 & 1113.200 \\
\hline 27 & 59.647 & 0.850 & 1.886 & 0.100 & 1113.200 \\
\hline 28 & 61.941 & 0.882 & 1.959 & 0.100 & 1113.200 \\
\hline 29 & 64.235 & 0.915 & 2.031 & 0.100 & 1113.200 \\
\hline 30 & 66.529 & 0.948 & 2.104 & 0.100 & 1113.200 \\
\hline 31 & 68.824 & 0.980 & 2.176 & 0.100 & 1113.200 \\
\hline
\end{tabular}


* irradiation history derived from input

\begin{tabular}{|c|c|c|c|c|c|}
\hline & & flut & bupt & xprest & \\
\hline *step & ttime (days) & $\left(\mathrm{e} 25 \mathrm{n} / \mathrm{m}^{\wedge} 2, \mathrm{E}>.18 \mathrm{MeV}\right)$ & ( $\%$ FIMA) & (mps) & btempt $(\mathrm{k})$ \\
\hline 32 & 71.118 & 1.013 & 2.249 & 0.100 & 1113.200 \\
\hline 33 & 73.412 & 1.046 & 2.322 & 0.100 & 1113.200 \\
\hline 34 & 75.706 & 1.078 & 2.394 & 0.100 & 1113.200 \\
\hline 35 & 78.000 & 1.111 & 2.467 & 0.100 & 1113.200 \\
\hline 36 & 80.294 & 1.144 & 2.539 & 0.100 & 1113.200 \\
\hline 37 & 82.588 & 1.176 & 2.612 & 0.100 & 1113.200 \\
\hline 38 & 84.882 & 1.209 & 2.684 & 0.100 & 1113.200 \\
\hline 39 & 87.176 & 1.242 & 2.757 & 0.100 & 1113.200 \\
\hline 40 & 89.471 & 1.275 & 2.829 & 0.100 & 1113.200 \\
\hline 41 & 91.765 & 1.307 & 2.902 & 0.100 & 1113.200 \\
\hline 42 & 94.059 & 1.340 & 2.975 & 0.100 & 1113.200 \\
\hline 43 & 96.353 & 1.373 & 3.047 & 0.100 & 1113.200 \\
\hline 44 & 98.647 & 1.405 & 3.120 & 0.100 & 1113.200 \\
\hline 45 & 100.941 & 1.438 & 3.192 & 0.100 & 1113.200 \\
\hline 46 & 103.235 & 1.471 & 3.265 & 0.100 & 1113.200 \\
\hline 47 & 105.529 & 1.503 & 3.337 & 0.100 & 1113.200 \\
\hline 48 & 107.824 & 1.536 & 3.410 & 0.100 & 1113.200 \\
\hline 49 & 110.118 & 1.569 & 3.482 & 0.100 & 1113.200 \\
\hline 50 & 112.412 & 1.601 & 3.555 & 0.100 & 1113.200 \\
\hline 51 & 114.706 & 1.634 & 3.627 & 0.100 & 1113.200 \\
\hline 52 & 117.000 & 1.667 & 3.700 & 0.100 & 1113.200 \\
\hline 53 & 119.294 & 1.699 & 3.773 & 0.100 & 1113.200 \\
\hline 54 & 121.588 & 1.732 & 3.845 & 0.100 & 1113.200 \\
\hline 55 & 123.882 & 1.765 & 3.918 & 0.100 & 1113.200 \\
\hline 56 & 126.176 & 1.797 & 3.990 & 0.100 & 1113.200 \\
\hline 57 & 128.471 & 1.830 & 4.063 & 0.100 & 1113.200 \\
\hline 58 & 130.765 & 1.863 & 4.135 & 0.100 & 1113.200 \\
\hline 59 & 133.059 & 1.895 & 4.208 & 0.100 & 1113.200 \\
\hline 60 & 135.353 & 1.928 & 4.280 & 0.100 & 1113.200 \\
\hline 61 & 137.647 & 1.961 & 4.353 & 0.100 & 1113.200 \\
\hline 62 & 139.941 & 1.993 & 4.425 & 0.100 & 1113.200 \\
\hline 63 & 142.235 & 2.026 & 4.498 & 0.100 & 1113.200 \\
\hline
\end{tabular}


* irradiation history derived from input

\begin{tabular}{|c|c|c|c|c|c|}
\hline & & flut & bupt & xprest & \\
\hline *step & ttime (days) & $\left(\mathrm{e} 25 \mathrm{n} / \mathrm{m}^{\wedge} 2, \mathrm{E}>.18 \mathrm{MeV}\right)$ & ( $\%$ FIMA) & (mps) & btempt $(\mathrm{k})$ \\
\hline 64 & 144.529 & 2.059 & 4.571 & 0.100 & 1113.200 \\
\hline 65 & 146.824 & 2.092 & 4.643 & 0.100 & 1113.200 \\
\hline 66 & 149.118 & 2.124 & 4.716 & 0.100 & 1113.200 \\
\hline 67 & 151.412 & 2.157 & 4.788 & 0.100 & 1113.200 \\
\hline 68 & 153.706 & 2.190 & 4.861 & 0.100 & 1113.200 \\
\hline 69 & 156.000 & 2.222 & 4.933 & 0.100 & 1113.200 \\
\hline 70 & 158.294 & 2.255 & 5.006 & 0.100 & 1113.200 \\
\hline 71 & 160.588 & 2.288 & 5.078 & 0.100 & 1113.200 \\
\hline 72 & 162.882 & 2.320 & 5.151 & 0.100 & 1113.200 \\
\hline 73 & 165.176 & 2.353 & 5.224 & 0.100 & 1113.200 \\
\hline 74 & 167.471 & 2.386 & 5.296 & 0.100 & 1113.200 \\
\hline 75 & 169.765 & 2.418 & 5.369 & 0.100 & 1113.200 \\
\hline 76 & 172.059 & 2.451 & 5.441 & 0.100 & 1113.200 \\
\hline 77 & 174.353 & 2.484 & 5.514 & 0.100 & 1113.200 \\
\hline 78 & 176.647 & 2.516 & 5.586 & 0.100 & 1113.200 \\
\hline 79 & 178.941 & 2.549 & 5.659 & 0.100 & 1113.200 \\
\hline 80 & 181.235 & 2.582 & 5.731 & 0.100 & 1113.200 \\
\hline 81 & 183.529 & 2.614 & 5.804 & 0.100 & 1113.200 \\
\hline 82 & 185.824 & 2.647 & 5.876 & 0.100 & 1113.200 \\
\hline 83 & 188.118 & 2.680 & 5.949 & 0.100 & 1113.200 \\
\hline 84 & 190.412 & 2.712 & 6.022 & 0.100 & 1113.200 \\
\hline 85 & 192.706 & 2.745 & 6.094 & 0.100 & 1113.200 \\
\hline 86 & 195.000 & 2.778 & 6.167 & 0.100 & 1113.200 \\
\hline 87 & 197.294 & 2.810 & 6.239 & 0.100 & 1113.200 \\
\hline 88 & 199.588 & 2.843 & 6.312 & 0.100 & 1113.200 \\
\hline 89 & 201.882 & 2.876 & 6.384 & 0.100 & 1113.200 \\
\hline 90 & 204.176 & 2.908 & 6.457 & 0.100 & 1113.200 \\
\hline 91 & 206.471 & 2.941 & 6.529 & 0.100 & 1113.200 \\
\hline 92 & 208.765 & 2.974 & 6.602 & 0.100 & 1113.200 \\
\hline 93 & 211.059 & 3.007 & 6.675 & 0.100 & 1113.200 \\
\hline 94 & 213.353 & 3.039 & 6.747 & 0.100 & 1113.200 \\
\hline 95 & 215.647 & 3.072 & 6.820 & 0.100 & 1113.200 \\
\hline
\end{tabular}


* irradiation history derived from input

\begin{tabular}{|c|c|c|c|c|c|}
\hline & & flut & bupt & xprest & \\
\hline *step & ttime (days) & $\left(\mathrm{e} 25 \mathrm{n} / \mathrm{m}^{\wedge} 2, \mathrm{E}>.18 \mathrm{MeV}\right)$ & $(\%$ FIMA) & (mps) & btempt $(\mathrm{k})$ \\
\hline 96 & 217.941 & 3.105 & 6.892 & 0.100 & 1113.200 \\
\hline 97 & 220.235 & 3.137 & 6.965 & 0.100 & 1113.200 \\
\hline 98 & 222.529 & 3.170 & 7.037 & 0.100 & 1113.200 \\
\hline 99 & 224.824 & 3.203 & 7.110 & 0.100 & 1113.200 \\
\hline 100 & 227.118 & 3.235 & 7.182 & 0.100 & 1113.200 \\
\hline 101 & 229.412 & 3.268 & 7.255 & 0.100 & 1113.200 \\
\hline 102 & 231.706 & 3.301 & 7.327 & 0.100 & 1113.200 \\
\hline 103 & 234.000 & 3.333 & 7.400 & 0.100 & 1113.200 \\
\hline 104 & 236.294 & 3.366 & 7.473 & 0.100 & 1113.200 \\
\hline 105 & 238.588 & 3.399 & 7.545 & 0.100 & 1113.200 \\
\hline 106 & 240.882 & 3.431 & 7.618 & 0.100 & 1113.200 \\
\hline 107 & 243.176 & 3.464 & 7.690 & 0.100 & 1113.200 \\
\hline 108 & 245.471 & 3.497 & 7.763 & 0.100 & 1113.200 \\
\hline 109 & 247.765 & 3.529 & 7.835 & 0.100 & 1113.200 \\
\hline 110 & 250.059 & 3.562 & 7.908 & 0.100 & 1113.200 \\
\hline 111 & 252.353 & 3.595 & 7.980 & 0.100 & 1113.200 \\
\hline 112 & 254.647 & 3.627 & 8.053 & 0.100 & 1113.200 \\
\hline 113 & 256.941 & 3.660 & 8.125 & 0.100 & 1113.200 \\
\hline 114 & 259.235 & 3.693 & 8.198 & 0.100 & 1113.200 \\
\hline 115 & 261.529 & 3.725 & 8.271 & 0.100 & 1113.200 \\
\hline 116 & 263.824 & 3.758 & 8.343 & 0.100 & 1113.200 \\
\hline 117 & 266.118 & 3.791 & 8.416 & 0.100 & 1113.200 \\
\hline 118 & 268.412 & 3.824 & 8.488 & 0.100 & 1113.200 \\
\hline 119 & 270.706 & 3.856 & 8.561 & 0.100 & 1113.200 \\
\hline 120 & 273.000 & 3.889 & 8.633 & 0.100 & 1113.200 \\
\hline 121 & 275.294 & 3.922 & 8.706 & 0.100 & 1113.200 \\
\hline 122 & 277.588 & 3.954 & 8.778 & 0.100 & 1113.200 \\
\hline 123 & 279.882 & 3.987 & 8.851 & 0.100 & 1113.200 \\
\hline 124 & 282.176 & 4.020 & 8.924 & 0.100 & 1113.200 \\
\hline 125 & 284.471 & 4.052 & 8.996 & 0.100 & 1113.200 \\
\hline 126 & 286.765 & 4.085 & 9.069 & 0.100 & 1113.200 \\
\hline 127 & 289.059 & 4.118 & 9.141 & 0.100 & 1113.200 \\
\hline
\end{tabular}


* $\quad$ irradiation history derived from input

\begin{tabular}{|c|c|c|c|c|c|}
\hline & & flut & bupt & xprest & \\
\hline *step & ttime (days) & $\left(\mathrm{e} 25 \mathrm{n} / \mathrm{m}^{\wedge} 2, \mathrm{E}>.18 \mathrm{MeV}\right)$ & $(\%$ FIMA $)$ & (mps) & btempt $(\mathrm{k})$ \\
\hline 128 & 291.353 & 4.150 & 9.214 & 0.100 & 1113.200 \\
\hline 129 & 293.647 & 4.183 & 9.286 & 0.100 & 1113.200 \\
\hline 130 & 295.941 & 4.216 & 9.359 & 0.100 & 1113.200 \\
\hline 131 & 298.235 & 4.248 & 9.431 & 0.100 & 1113.200 \\
\hline 132 & 300.529 & 4.281 & 9.504 & 0.100 & 1113.200 \\
\hline 133 & 302.824 & 4.314 & 9.576 & 0.100 & 1113.200 \\
\hline 134 & 305.118 & 4.346 & 9.649 & 0.100 & 1113.200 \\
\hline 135 & 307.412 & 4.379 & 9.722 & 0.100 & 1113.200 \\
\hline 136 & 309.706 & 4.412 & 9.794 & 0.100 & 1113.200 \\
\hline 137 & 312.000 & 4.444 & 9.867 & 0.100 & 1113.200 \\
\hline 138 & 314.294 & 4.477 & 9.939 & 0.100 & 1113.200 \\
\hline 139 & 316.588 & 4.510 & 10.012 & 0.100 & 1113.200 \\
\hline 140 & 318.882 & 4.542 & 10.084 & 0.100 & 1113.200 \\
\hline 141 & 321.176 & 4.575 & 10.157 & 0.100 & 1113.200 \\
\hline 142 & 323.471 & 4.608 & 10.229 & 0.100 & 1113.200 \\
\hline 143 & 325.765 & 4.641 & 10.302 & 0.100 & 1113.200 \\
\hline 144 & 328.059 & 4.673 & 10.375 & 0.100 & 1113.200 \\
\hline 145 & 330.353 & 4.706 & 10.447 & 0.100 & 1113.200 \\
\hline 146 & 332.647 & 4.739 & 10.520 & 0.100 & 1113.200 \\
\hline 147 & 334.941 & 4.771 & 10.592 & 0.100 & 1113.200 \\
\hline 148 & 337.235 & 4.804 & 10.665 & 0.100 & 1113.200 \\
\hline 149 & 339.529 & 4.837 & 10.737 & 0.100 & 1113.200 \\
\hline 150 & 341.824 & 4.869 & 10.810 & 0.100 & 1113.200 \\
\hline 151 & 344.118 & 4.902 & 10.882 & 0.100 & 1113.200 \\
\hline 152 & 346.412 & 4.935 & 10.955 & 0.100 & 1113.200 \\
\hline 153 & 348.706 & 4.967 & 11.027 & 0.100 & 1113.200 \\
\hline 154 & 351.000 & 5.000 & 11.100 & 0.100 & 1113.200 \\
\hline 155 & 351.167 & 5.000 & 11.100 & 0.100 & 1056.433 \\
\hline 156 & 351.333 & 5.000 & 11.100 & 0.100 & 999.667 \\
\hline 157 & 351.500 & 5.000 & 11.100 & 0.100 & 893.000 \\
\hline 158 & 351.667 & 5.000 & 11.100 & 0.100 & 786.333 \\
\hline 159 & 351.833 & 5.000 & 11.100 & 0.100 & 679.666 \\
\hline
\end{tabular}


* $\quad$ irradiation history derived from input

\begin{tabular}{|c|c|c|c|c|c|}
\hline & & flut & bupt & xprest & \\
\hline *step & ttime (days) & $\left(\mathrm{e} 25 \mathrm{n} / \mathrm{m}^{\wedge} 2, \mathrm{E}>.18 \mathrm{MeV}\right)$ & ( $\%$ FIMA) & $(\operatorname{mps})$ & btempt $(\mathrm{k})$ \\
\hline 160 & 352.000 & 5.000 & 11.100 & 0.100 & 573.000 \\
\hline 161 & 352.010 & 5.000 & 11.100 & 0.100 & 573.000 \\
\hline 162 & 352.021 & 5.000 & 11.100 & 0.100 & 573.000 \\
\hline 163 & 352.031 & 5.000 & 11.100 & 0.100 & 698.000 \\
\hline 164 & 352.042 & 5.000 & 11.100 & 0.100 & 823.000 \\
\hline 165 & 352.052 & 5.000 & 11.100 & 0.100 & 948.000 \\
\hline 166 & 352.062 & 5.000 & 11.100 & 0.100 & 1073.000 \\
\hline 167 & 352.073 & 5.000 & 11.100 & 0.100 & 1198.000 \\
\hline 168 & 352.083 & 5.000 & 11.100 & 0.100 & 1323.000 \\
\hline 169 & 352.198 & 5.000 & 11.100 & 0.100 & 1323.000 \\
\hline 170 & 352.313 & 5.000 & 11.100 & 0.100 & 1323.000 \\
\hline 171 & 352.323 & 5.000 & 11.100 & 0.100 & 1423.000 \\
\hline 172 & 352.333 & 5.000 & 11.100 & 0.100 & 1523.000 \\
\hline 173 & 352.615 & 5.000 & 11.100 & 0.100 & 1523.000 \\
\hline 174 & 352.896 & 5.000 & 11.100 & 0.100 & 1523.000 \\
\hline 175 & 352.974 & 5.000 & 11.100 & 0.100 & 1610.500 \\
\hline 176 & 353.052 & 5.000 & 11.100 & 0.100 & 1698.000 \\
\hline 177 & 353.130 & 5.000 & 11.100 & 0.100 & 1785.500 \\
\hline 178 & 353.208 & 5.000 & 11.100 & 0.100 & 1873.000 \\
\hline 179 & 355.319 & 5.000 & 11.100 & 0.100 & 1873.000 \\
\hline 180 & 357.431 & 5.000 & 11.100 & 0.100 & 1873.000 \\
\hline 181 & 359.542 & 5.000 & 11.100 & 0.100 & 1873.000 \\
\hline 182 & 359.653 & 5.000 & 11.100 & 0.100 & 1873.000 \\
\hline 183 & 363.764 & 5.000 & 11.100 & 0.100 & 1873.000 \\
\hline 184 & 365.875 & 5.000 & 11.100 & 0.100 & 1873.000 \\
\hline
\end{tabular}

\footnotetext{
* time heatup starts

* thus (days)
}

$306001 \quad 352.000$

\footnotetext{
*

* correlation function coefficients for ipyc cracking

* $\quad$ sigcro (mpa) umc (mpa)
} 


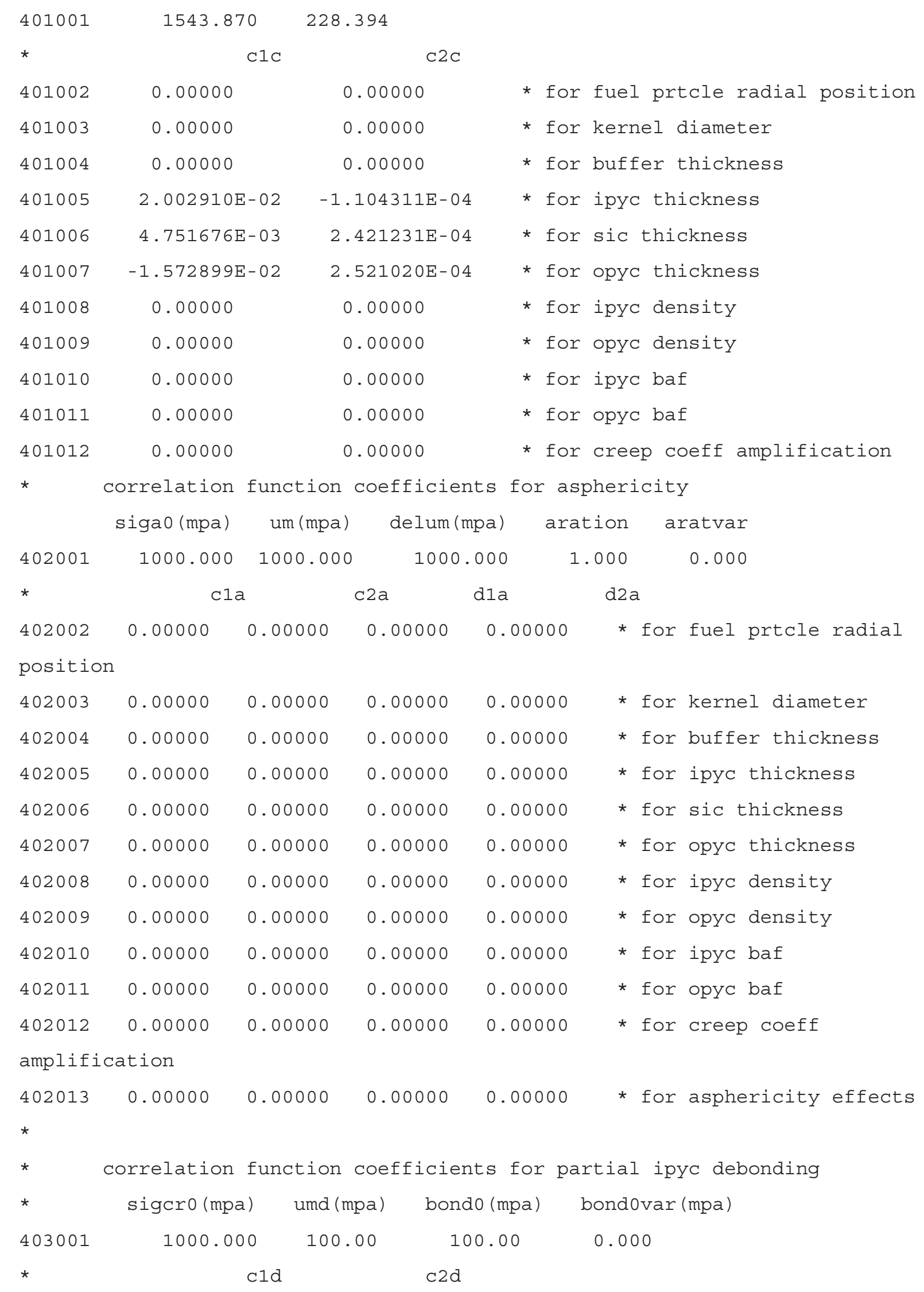




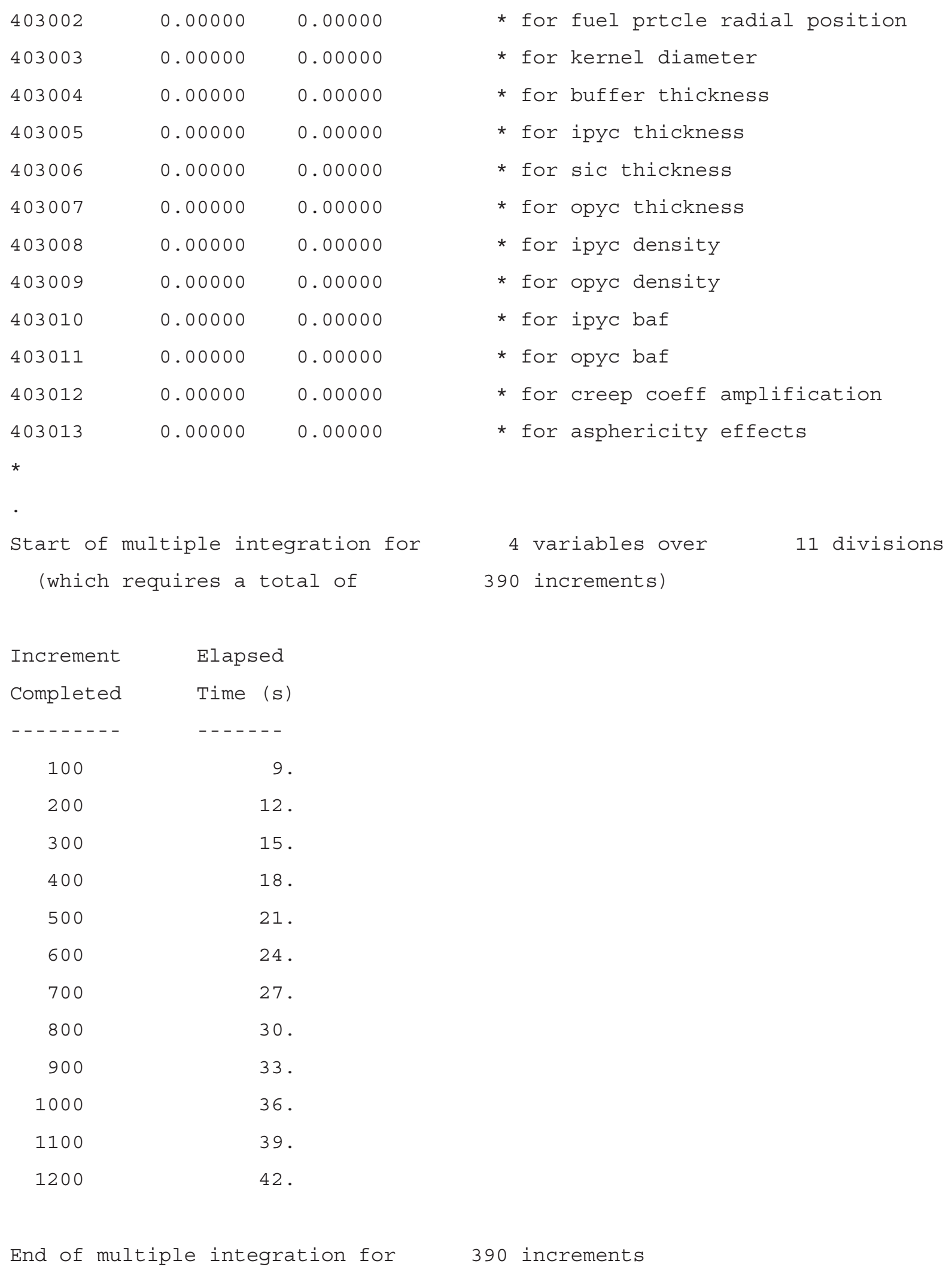




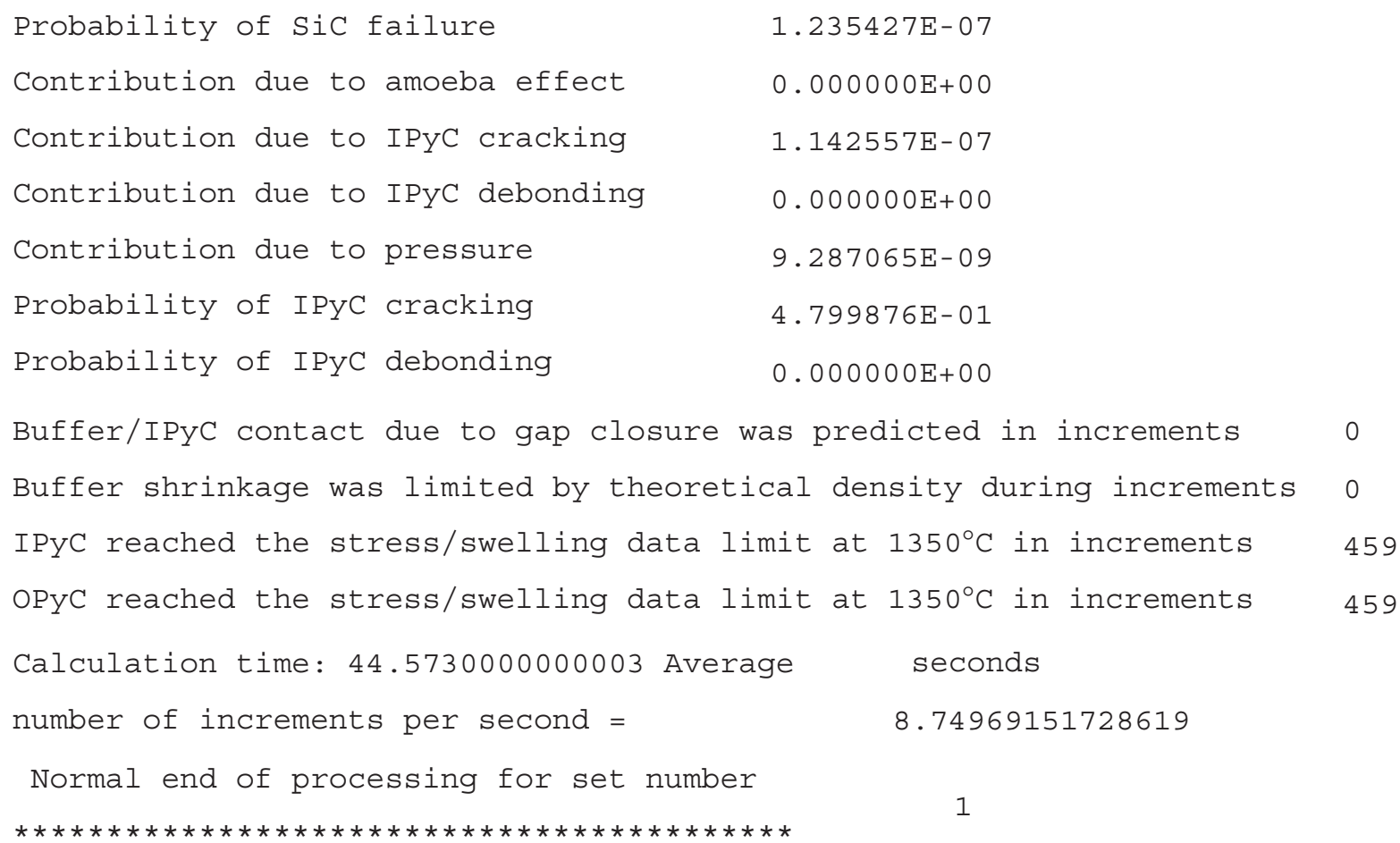


Failure probabilities vs time (s) and fast fluence $\left(10^{\wedge} 25 \mathrm{n} / \mathrm{m}^{\wedge} 2, \mathrm{E}>.18 \mathrm{MeV}\right)$

\begin{tabular}{|c|c|c|c|c|c|c|c|c|}
\hline \\
\hline TIME & FLU & TOTAL & AMOEBA & IPyC CRACK & IPyC DEBND & PRESSURE & IPyC CRACK & IPyC DEBND \\
\hline $0.000000 \mathrm{E}+00$ & $0.0000 \mathrm{E}+00$ & $0.0000 \mathrm{E}+00$ & $0.0000 \mathrm{E}+00$ & $0.0000 \mathrm{E}+00$ & $0.0000 \mathrm{E}+00$ & $0.0000 \mathrm{E}+00$ & $0.0000 \mathrm{E}+00$ & $0.0000 \mathrm{E}+00$ \\
\hline $1.982118 \mathrm{E}+05$ & $3.2680 \mathrm{E}-02$ & $0.0000 \mathrm{E}+00$ & $0.0000 \mathrm{E}+00$ & $0.0000 \mathrm{E}+00$ & $0.0000 \mathrm{E}+00$ & $0.0000 \mathrm{E}+00$ & $7.8722 \mathrm{E}-10$ & $0.0000 \mathrm{E}+00$ \\
\hline $3.964235 \mathrm{E}+05$ & $6.5359 \mathrm{E}-02$ & $0.0000 \mathrm{E}+00$ & $0.0000 \mathrm{E}+00$ & $0.0000 \mathrm{E}+00$ & $0.0000 \mathrm{E}+00$ & $0.0000 \mathrm{E}+00$ & $5.7001 \mathrm{E}-07$ & $0.0000 \mathrm{E}+00$ \\
\hline $7.928471 \mathrm{E}+05$ & $1.3072 \mathrm{E}-01$ & $2.6025 \mathrm{E}-12$ & $0.0000 \mathrm{E}+00$ & $2.6025 \mathrm{E}-12$ & $0.0000 \mathrm{E}+00$ & $0.0000 \mathrm{E}+00$ & $2.5401 \mathrm{E}-04$ & $0.0000 \mathrm{E}+00$ \\
\hline $9.910588 \mathrm{E}+05$ & $1.6340 \mathrm{E}-01$ & $1.8908 \mathrm{E}-11$ & $0.0000 \mathrm{E}+00$ & $1.8908 \mathrm{E}-11$ & $0.0000 \mathrm{E}+00$ & $0.0000 \mathrm{E}+00$ & $1.1108 \mathrm{E}-03$ & $0.0000 \mathrm{E}+00$ \\
\hline $1.189271 \mathrm{E}+06$ & $1.9608 \mathrm{E}-01$ & $6.8908 \mathrm{E}-11$ & $0.0000 \mathrm{E}+00$ & $6.8908 \mathrm{E}-11$ & $0.0000 \mathrm{E}+00$ & $0.0000 \mathrm{E}+00$ & $3.4312 \mathrm{E}-03$ & $0.0000 \mathrm{E}+00$ \\
\hline $1.387482 \mathrm{E}+06$ & $2.2876 \mathrm{E}-01$ & $1.5372 \mathrm{E}-10$ & $0.0000 \mathrm{E}+00$ & $1.5372 \mathrm{E}-10$ & $0.0000 \mathrm{E}+00$ & $0.0000 \mathrm{E}+00$ & $1.2764 \mathrm{E}-02$ & $0.0000 \mathrm{E}+00$ \\
\hline $1.585694 \mathrm{E}+06$ & $2.6144 \mathrm{E}-01$ & $3.8517 \mathrm{E}-10$ & $0.0000 \mathrm{E}+00$ & $3.8517 \mathrm{E}-10$ & $0.0000 \mathrm{E}+00$ & $0.0000 \mathrm{E}+00$ & $1.9217 \mathrm{E}-02$ & $0.0000 \mathrm{E}+00$ \\
\hline $1.783906 \mathrm{E}+06$ & $2.9412 \mathrm{E}-01$ & $7.1770 \mathrm{E}-10$ & $0.0000 \mathrm{E}+00$ & $7.1770 \mathrm{E}-10$ & $0.0000 \mathrm{E}+00$ & $0.0000 \mathrm{E}+00$ & $5.5732 \mathrm{E}-02$ & $0.0000 \mathrm{E}+00$ \\
\hline $1.982118 \mathrm{E}+06$ & $3.2680 \mathrm{E}-01$ & $7.1770 \mathrm{E}-10$ & $0.0000 \mathrm{E}+00$ & $7.1770 \mathrm{E}-10$ & $0.0000 \mathrm{E}+00$ & $0.0000 \mathrm{E}+00$ & $5.5732 \mathrm{E}-02$ & $0.0000 \mathrm{E}+00$ \\
\hline $2.180329 \mathrm{E}+06$ & $3.5948 \mathrm{E}-01$ & $9.4016 \mathrm{E}-09$ & $0.0000 \mathrm{E}+00$ & $9.4016 \mathrm{E}-09$ & $0.0000 \mathrm{E}+00$ & $0.0000 \mathrm{E}+00$ & $8.0129 \mathrm{E}-02$ & $0.0000 \mathrm{E}+00$ \\
\hline $2.378541 \mathrm{E}+06$ & $3.9216 \mathrm{E}-01$ & $4.0765 \mathrm{E}-08$ & $0.0000 \mathrm{E}+00$ & 4.0765E-08 & $0.0000 \mathrm{E}+00$ & $0.0000 \mathrm{E}+00$ & $1.8889 \mathrm{E}-01$ & $0.0000 \mathrm{E}+00$ \\
\hline $2.576753 \mathrm{E}+06$ & $4.2484 \mathrm{E}-01$ & $4.4439 \mathrm{E}-08$ & $0.0000 \mathrm{E}+00$ & 4.4439E- 08 & $0.0000 \mathrm{E}+00$ & $0.0000 \mathrm{E}+00$ & $1.8889 \mathrm{E}-01$ & $0.0000 \mathrm{E}+00$ \\
\hline $2.774965 \mathrm{E}+06$ & $4.5752 \mathrm{E}-01$ & $4.5370 \mathrm{E}-08$ & $0.0000 \mathrm{E}+00$ & $4.5370 \mathrm{E}-08$ & $0.0000 \mathrm{E}+00$ & $0.0000 \mathrm{E}+00$ & $1.8889 \mathrm{E}-01$ & $0.0000 \mathrm{E}+00$ \\
\hline $2.973176 \mathrm{E}+06$ & $4.9020 \mathrm{E}-01$ & $5.7241 \mathrm{E}-08$ & $0.0000 \mathrm{E}+00$ & $5.7241 \mathrm{E}-08$ & $0.0000 \mathrm{E}+00$ & $0.0000 \mathrm{E}+00$ & $2.5353 \mathrm{E}-01$ & $0.0000 \mathrm{E}+00$ \\
\hline $3.567812 \mathrm{E}+06$ & $5.8824 \mathrm{E}-01$ & $1.1426 \mathrm{E}-07$ & $0.0000 \mathrm{E}+00$ & $1.1426 \mathrm{E}-07$ & $0.0000 \mathrm{E}+00$ & $0.0000 \mathrm{E}+00$ & 4.7999E-01 & $0.0000 \mathrm{E}+00$ \\
\hline $3.766024 \mathrm{E}+06$ & $6.2092 \mathrm{E}-01$ & $1.1426 \mathrm{E}-07$ & $0.0000 \mathrm{E}+00$ & $1.1426 \mathrm{E}-07$ & $0.0000 \mathrm{E}+00$ & $0.0000 \mathrm{E}+00$ & 4.7999E-01 & $0.0000 \mathrm{E}+00$ \\
\hline $3.964235 \mathrm{E}+06$ & $6.5359 \mathrm{E}-01$ & $1.1426 \mathrm{E}-07$ & $0.0000 \mathrm{E}+00$ & $1.1426 \mathrm{E}-07$ & $0.0000 \mathrm{E}+00$ & $0.0000 \mathrm{E}+00$ & 4.7999E-01 & $0.0000 \mathrm{E}+00$ \\
\hline $4.162447 \mathrm{E}+06$ & $6.8627 \mathrm{E}-01$ & $1.1426 \mathrm{E}-07$ & $0.0000 \mathrm{E}+00$ & $1.1426 \mathrm{E}-07$ & $0.0000 \mathrm{E}+00$ & $0.0000 \mathrm{E}+00$ & 4.7999E-01 & $0.0000 \mathrm{E}+00$ \\
\hline $4.360659 \mathrm{E}+06$ & $7.1895 \mathrm{E}-01$ & $1.1426 \mathrm{E}-07$ & $0.0000 \mathrm{E}+00$ & $1.1426 \mathrm{E}-07$ & $0.0000 \mathrm{E}+00$ & $0.0000 \mathrm{E}+00$ & 4.7999E-01 & $0.0000 \mathrm{E}+00$ \\
\hline \multicolumn{9}{|c|}{ DATA INTENTIONALLY REMOVED TO REDUCE PAGE COUNT } \\
\hline $3.049020 \mathrm{E}+07$ & $5.0000 \mathrm{E}+00$ & $1.1426 \mathrm{E}-07$ & $0.0000 \mathrm{E}+00$ & $1.1426 \mathrm{E}-07$ & $0.0000 \mathrm{E}+00$ & $0.0000 \mathrm{E}+00$ & 4.7999E-01 & $0.0000 \mathrm{E}+00$ \\
\hline $3.049695 \mathrm{E}+07$ & $5.0000 \mathrm{E}+00$ & $1.1981 \mathrm{E}-07$ & $0.0000 \mathrm{E}+00$ & $1.1426 \mathrm{E}-07$ & $0.0000 \mathrm{E}+00$ & $5.5518 \mathrm{E}-09$ & 4.7999E-01 & $0.0000 \mathrm{E}+00$ \\
\hline $3.050370 \mathrm{E}+07$ & $5.0000 \mathrm{E}+00$ & $1.2354 \mathrm{E}-07$ & $0.0000 \mathrm{E}+00$ & $1.1426 \mathrm{E}-07$ & $0.0000 \mathrm{E}+00$ & $9.2871 \mathrm{E}-09$ & 4.7999E-01 & $0.0000 \mathrm{E}+00$ \\
\hline $3.051045 \mathrm{E}+07$ & $5.0000 \mathrm{E}+00$ & $1.2354 \mathrm{E}-07$ & $0.0000 \mathrm{E}+00$ & $1.1426 \mathrm{E}-07$ & $0.0000 \mathrm{E}+00$ & $9.2871 \mathrm{E}-09$ & 4.7999E-01 & $0.0000 \mathrm{E}+00$ \\
\hline $3.051720 \mathrm{E}+07$ & $5.0000 \mathrm{E}+00$ & $1.2354 \mathrm{E}-07$ & $0.0000 \mathrm{E}+00$ & $1.1426 \mathrm{E}-07$ & $0.0000 \mathrm{E}+00$ & $9.2871 \mathrm{E}-09$ & 4.7999E-01 & $0.0000 \mathrm{E}+00$ \\
\hline $3.069960 \mathrm{E}+07$ & $5.0000 \mathrm{E}+00$ & $1.2354 \mathrm{E}-07$ & $0.0000 \mathrm{E}+00$ & $1.1426 \mathrm{E}-07$ & $0.0000 \mathrm{E}+00$ & $9.2871 \mathrm{E}-09$ & 4.7999E-01 & $0.0000 \mathrm{E}+00$ \\
\hline $3.088200 \mathrm{E}+07$ & $5.0000 \mathrm{E}+00$ & $1.2354 \mathrm{E}-07$ & $0.0000 \mathrm{E}+00$ & $1.1426 \mathrm{E}-07$ & $0.0000 \mathrm{E}+00$ & $9.2871 \mathrm{E}-09$ & 4.7999E-01 & $0.0000 \mathrm{E}+00$ \\
\hline $3.106440 \mathrm{E}+07$ & $5.0000 \mathrm{E}+00$ & $1.2354 \mathrm{E}-07$ & $0.0000 \mathrm{E}+00$ & $1.1426 \mathrm{E}-07$ & $0.0000 \mathrm{E}+00$ & $9.2871 \mathrm{E}-09$ & 4.7999E-01 & $0.0000 \mathrm{E}+00$ \\
\hline $3.124680 \mathrm{E}+07$ & $5.0000 \mathrm{E}+00$ & $1.2354 \mathrm{E}-07$ & $0.0000 \mathrm{E}+00$ & $1.1426 \mathrm{E}-07$ & $0.0000 \mathrm{E}+00$ & $9.2871 \mathrm{E}-09$ & 4.7999E-01 & $0.0000 \mathrm{E}+00$ \\
\hline $3.142920 \mathrm{E}+07$ & $5.0000 \mathrm{E}+00$ & $1.2354 \mathrm{E}-07$ & $0.0000 \mathrm{E}+00$ & $1.1426 \mathrm{E}-07$ & $0.0000 \mathrm{E}+00$ & $9.2871 \mathrm{E}-09$ & $4.7999 \mathrm{E}-01$ & $0.0000 \mathrm{E}+00$ \\
\hline
\end{tabular}



TIME

$0.000000 \mathrm{E}+00$

$1.982118 \mathrm{E}+05$

$3.964235 \mathrm{E}+05$

$5.946353 \mathrm{E}+05$

$7.928471 \mathrm{E}+05$

$9.910588 \mathrm{E}+05$

$1.189271 \mathrm{E}+06$

$1.387482 \mathrm{E}$

$1.585694 \mathrm{E}+06$

$1.783906 \mathrm{E}+06$

$1.982118 \mathrm{E}+06$

$2.180329 \mathrm{E}+06$

$2.378541 \mathrm{E}+06$

$2.576753 \mathrm{E}+06$

$2.774965 \mathrm{E}+06$

$2.973176 \mathrm{E}+06$

$3.171388 \mathrm{E}+06$

$3.369600 \mathrm{E}+06$

$3.567812 \mathrm{E}+06$

$2.596574 \mathrm{E}+07$

$2.616395 \mathrm{E}+07$

$2.636216 \mathrm{E}+07$

$2.656038 \mathrm{E}+07$

$2.675859 \mathrm{E}+07$

$2.695680 \mathrm{E}+07$

$2.715501 \mathrm{E}+07$

$2.735322 \mathrm{E}+07$

$2.755144 \mathrm{E}+07$

$2.774965 \mathrm{E}+07$

$2.794786 \mathrm{E}+07$

$2.814607 \mathrm{E}+07$

$2.834428 \mathrm{E}+07$

$2.854249 \mathrm{E}+07$

$2.874071 \mathrm{E}+07$

$2.893892 \mathrm{E}+07$

$2.913713 \mathrm{E}+07$

$2.933534 \mathrm{E}+07$

$2.953355 \mathrm{E}+07$

$2.973176 \mathrm{E}+07$

\section{FLU}

$0.0000 \mathrm{E}+00$

$3.2680 \mathrm{E}-02$

$6.5359 \mathrm{E}-02$

$9.8039 \mathrm{E}-02$

$1.3072 \mathrm{E}-01$

$1.6340 \mathrm{E}-01$

$1.9608 \mathrm{E}-01$

$2.2876 \mathrm{E}-01$

2.6144E-01

2.9412E-01

$3.2680 \mathrm{E}-01$

$3.5948 \mathrm{E}-01$

$3.9216 \mathrm{E}-01$

4.2484E-01

$4.5752 \mathrm{E}-01$

4.9020E-01

$5.2288 \mathrm{E}-01$

$5.5556 \mathrm{E}-01$

$5.8824 \mathrm{E}-01$

$4.2810 \mathrm{E}+00$

$4.3137 \mathrm{E}+00$

$4.3464 \mathrm{E}+00$

$4.3791 \mathrm{E}+00$

$4.4118 \mathrm{E}+00$

$4.4444 \mathrm{E}+00$

$4.4771 \mathrm{E}+00$

$4.5098 \mathrm{E}+00$

$4.5425 \mathrm{E}+00$

$4.5752 \mathrm{E}+00$

$4.6078 \mathrm{E}+00$

$4.6405 \mathrm{E}+00$

$4.6732 \mathrm{E}+00$

$4.7059 \mathrm{E}+00$

$4.7386 \mathrm{E}+00$

$4.7712 \mathrm{E}+00$

$4.8039 \mathrm{E}+00$

$4.8366 \mathrm{E}+00$

$4.8693 \mathrm{E}+00$

$4.9020 \mathrm{E}+00$
IPC/SiC,ri

$-1.3180 \mathrm{E}-01$

$4.4161 \mathrm{E}+00$

$8.6031 \mathrm{E}+00$

$1.2401 \mathrm{E}+01$

$1.5837 \mathrm{E}+0$

$1.8937 \mathrm{E}+01$

$2.1727 \mathrm{E}+01$

$2.4230 \mathrm{E}+0$

$2.6468 \mathrm{E}+01$

$2.8462 \mathrm{E}+0$

$3.0230 \mathrm{E}+01$

$3.1792 \mathrm{E}+0$

$3.3163 \mathrm{E}+01$

$3.4359 \mathrm{E}+01$

$3.5394 \mathrm{E}+01$

$3.6281 \mathrm{E}+0$

$3.7033 \mathrm{E}+0$

$3.7660 \mathrm{E}+01$

$3.8173 \mathrm{E}+01$

$-2.2593 \mathrm{E}+00$

$-2.4520 \mathrm{E}+00$

$-2.6561 \mathrm{E}+00$

$-2.8694 \mathrm{E}+00$

$-3.0906 \mathrm{E}+00$

$-3.3182 \mathrm{E}+00$

$-3.5512 \mathrm{E}+00$

$-3.7893 \mathrm{E}+00$

$-4.0335 \mathrm{E}+00$

$-4.2843 \mathrm{E}+00$

$-4.5405 \mathrm{E}+00$

$-4.8014 \mathrm{E}+00$

$-5.0663 \mathrm{E}+00$

$-5.3347 \mathrm{E}+00$

$-5.6061 \mathrm{E}+00$

$-5.8800 \mathrm{E}+00$

$-6.1562 \mathrm{E}+00$

$-6.4345 \mathrm{E}+00$

$-6.7145 \mathrm{E}+00$

$-6.9961 \mathrm{E}+00$ a) vs ti

$-1.0023 \mathrm{E}-01$

$-3.5948 \mathrm{E}+00$

$-6.7322 \mathrm{E}+00$

$-9.4550 \mathrm{E}+00$

$-1.1812 \mathrm{E}+01$

$-1.3847 \mathrm{E}+01$

$-1.5598 \mathrm{E}+01$

$-1.7100 \mathrm{E}+01$

$-1.8384 \mathrm{E}+01$

$-1.9475 \mathrm{E}+01$

$-2.0396 \mathrm{E}+01$

$-2.1169 \mathrm{E}+01$

$-2.1812 \mathrm{E}+01$

$-2.2340 \mathrm{E}+01$

$-2.2767 \mathrm{E}+01$

$-2.3106 \mathrm{E}+01$

$-2.3368 \mathrm{E}+01$

$-2.3561 \mathrm{E}+01$

$-2.3693 \mathrm{E}+01$

DATA

$-9.4244 \mathrm{E}+00$

$-9.4727 \mathrm{E}+00$

$-9.5171 \mathrm{E}+00$

$-9.5585 \mathrm{E}+00$

$-9.5974 \mathrm{E}+00$

$-9.6344 \mathrm{E}+00$

$-9.6697 \mathrm{E}+00$

$-9.7033 \mathrm{E}+00$

$-9.7334 \mathrm{E}+00$

$-9.7597 \mathrm{E}+00$

$-9.7830 \mathrm{E}+00$

$-9.8039 \mathrm{E}+00$

$-9.8230 \mathrm{E}+00$

$-9.8407 \mathrm{E}+00$

$-9.8573 \mathrm{E}+00$

$-9.8730 \mathrm{E}+00$

$-9.8881 \mathrm{E}+00$

$-9.9026 \mathrm{E}+00$

$-9.9167 \mathrm{E}+00$

$-9.9305 \mathrm{E}+00$
IPyC $\mathrm{ti}$

$-6.8728 \mathrm{E}-02$

$2.3030 \mathrm{E}+01$

$4.4975 \mathrm{E}+01$

$6.4902 \mathrm{E}+01$

$8.2952 \mathrm{E}+01$

$9.9264 \mathrm{E}+01$

$1.1397 \mathrm{E}+02$

$1.2720 \mathrm{E}+02$

$1.3905 \mathrm{E}+02$

$1.4965 \mathrm{E}+02$

$.5908 \mathrm{E}+02$

$1.6745 \mathrm{E}+02$

$1.7484 \mathrm{E}+02$

$1.8133 \mathrm{E}+02$

$.8700 \mathrm{E}+02$

$1.9191 \mathrm{E}+02$

$1.9612 \mathrm{E}+02$

$1.9970 \mathrm{E}+02$

$2.0270 \mathrm{E}+02$

IPyC, to

$-6.2138 \mathrm{E}-02$

$2.0833 \mathrm{E}+01$

$8603 \mathrm{E}+0$

$7.4993 \mathrm{E}+0$

$8.9872 \mathrm{E}+01$

$1.0335 \mathrm{E}+02$

$1.1553 \mathrm{E}+02$

$1.2650 \mathrm{E}+02$

$1.3636 \mathrm{E}+02$

$1.4519 \mathrm{E}+02$

$1.5308 \mathrm{E}+02$

$1.6008 \mathrm{E}+02$

$1.6628 \mathrm{E}+02$

$1.7174 \mathrm{E}+02$

$1.7652 \mathrm{E}+02$

$1.8066 \mathrm{E}+02$

$1.8726 \mathrm{E}+02$

$\mathrm{SiC}, \mathrm{ti}$

$-5.6648 \mathrm{E}-01$

$-4.6503 \mathrm{E}+01$

$-8.8861 \mathrm{E}+0$

$-1.2649 \mathrm{E}+02$

$-1.5985 \mathrm{E}+02$

$-1.8936 \mathrm{E}+02$

$2.1541 \mathrm{E}+02$

$-2.3833 \mathrm{E}+02$

$-2.5845 \mathrm{E}+02$

$-2.7603 \mathrm{E}+02$

$-2.9134 \mathrm{E}+02$

$-3.0460 \mathrm{E}+02$

$-3.1600 \mathrm{E}+02$

$-3.2575 \mathrm{E}+02$

$-3.3399 \mathrm{E}+02$

$-3.4088 \mathrm{E}+02$

$-3.4656 \mathrm{E}+02$

$-3.5113 \mathrm{E}+02$

$-3.5472 \mathrm{E}+02$

.

$8.6553 \mathrm{E}+01$

$-4.7798 \mathrm{E}+01$

$8.6766 \mathrm{E}+01$

$-4.7073 \mathrm{E}+0$

$7.6969 \mathrm{E}+01$

$8.6923 \mathrm{E}+01$

$-4.6262 \mathrm{E}+01$

$7.7097 \mathrm{E}+01$

$7.7186 \mathrm{E}+01$

$8.7033 \mathrm{E}+0$

$8.7106 \mathrm{E}+01$

$-4.5383 \mathrm{E}+0$

$7.7243 \mathrm{E}+01$

$7.7275 \mathrm{E}+01$

$7.7283 \mathrm{E}+01$

$7.7261 \mathrm{E}+01$

$7.7207 \mathrm{E}+01$

$7.7127 \mathrm{E}+01$

$7.7025 \mathrm{E}+01$

$7.6905 \mathrm{E}+01$

$7.6769 \mathrm{E}+01$

$7.6621 \mathrm{E}+01$

$7.6463 \mathrm{E}+01$

$7.6295 \mathrm{E}+01$

$7.6120 \mathrm{E}+01$

$7.5939 \mathrm{E}+01$

$7.5753 \mathrm{E}+01$
$8.7148 \mathrm{E}+01$

$8.7165 \mathrm{E}+01$

$8.7159 \mathrm{E}+01$

$8.7124 \mathrm{E}+01$

$8.7057 \mathrm{E}+01$

$8.6965 \mathrm{E}+01$

$8.6851 \mathrm{E}+01$

$8.6720 \mathrm{E}+01$

$8.6574 \mathrm{E}+01$

$8.6416 \mathrm{E}+01$

$8.6248 \mathrm{E}+01$

$8.6072 \mathrm{E}+01$

$8.5888 \mathrm{E}+01$

$8.5699 \mathrm{E}+01$

$8.5505 \mathrm{E}+01$

$\mathrm{SiC}$ to

$-5.2296 \mathrm{E}-0$

$-4.2498 \mathrm{E}+01$

$-8.1193 \mathrm{E}+0$

$-1.1556 \mathrm{E}+02$

$-1.4602 \mathrm{E}+02$

$-1.7297 \mathrm{E}+02$

$-1.9674 \mathrm{E}+02$

$-2.1767 \mathrm{E}+02$

$-2.3602 \mathrm{E}+02$

$-2.5207 \mathrm{E}+02$

$2.6603 \mathrm{E}+02$

$-2.7812 \mathrm{E}+02$

$-2.8852 \mathrm{E}+02$

$-2.9740 \mathrm{E}+02$

$-3.0491 \mathrm{E}+02$

$-3.1119 \mathrm{E}+02$ 
PARTICLE nominal temperature histories (in $K$ )

\begin{tabular}{|c|c|c|c|c|c|c|c|c|c|c|c|c|}
\hline Time (s) & $\mathrm{TP}(1)$ & $\mathrm{TP}(2)$ & $\mathrm{TP}(3)$ & $\operatorname{TP}(4)$ & $\mathrm{TP}(5)$ & $\operatorname{TP}(6)$ & $\mathrm{TP}(7)$ & $\mathrm{TP}(8)$ & $\operatorname{TP}(9)$ & $\operatorname{TP}(10)$ & $\operatorname{TP}(11)$ & $\operatorname{TP}(12)$ \\
\hline $0.000000 \mathrm{E}+00$ & 1113.20 & 1113.20 & 1113.20 & 1113.20 & 1113.20 & 1113.20 & 1113.20 & 1113.20 & 1113.20 & 1113.20 & 1113.20 & 1113.20 \\
\hline $1.982118 \mathrm{E}+05$ & 1197.48 & 1197.48 & 1197.47 & 1197.46 & 1197.43 & 1197.40 & 1197.36 & 1197.32 & 1197.26 & 1197.20 & 1197.13 & 1197.05 \\
\hline $3.964235 E+05$ & 1199.37 & 1199.37 & 1199.36 & 1199.35 & 1199.32 & 1199.29 & 1199.25 & 1199.21 & 1199.15 & 1199.09 & 1199.02 & 1198.94 \\
\hline $5.946353 \mathrm{E}+05$ & 1200.96 & 1200.96 & 1200.95 & 1200.93 & 1200.91 & 1200.88 & 1200.84 & 1200.79 & 1200.74 & 1200.67 & 1200.60 & 1200.53 \\
\hline $7.928471 \mathrm{E}+05$ & 1202.74 & 1202.74 & 1202.73 & 1202.72 & 1202.70 & 1202.66 & 1202.63 & 1202.58 & 1202.52 & 1202.46 & 1202.39 & 1202.31 \\
\hline $9.910588 E+05$ & 1204.67 & 1204.67 & 1204.66 & 1204.65 & 1204.62 & 1204.59 & 1204.55 & 1204.50 & 1204.45 & 1204.39 & 1204.32 & 1204.24 \\
\hline $1.189271 \mathrm{E}+06$ & 1206.68 & 1206.68 & 1206.68 & 1206.66 & 1206.64 & 1206.61 & 1206.57 & 1206.52 & 1206.46 & 1206.40 & 1206.33 & 1206.25 \\
\hline $1.387482 \mathrm{E}+06$ & 1208.73 & 1208.73 & 1208.72 & 1208.71 & 1208.69 & 1208.65 & 1208.61 & 1208.57 & 1208.51 & 1208.45 & 1208.38 & 1208.30 \\
\hline $1.585694 \mathrm{E}+06$ & 1210.73 & 1210.73 & 1210.72 & 1210.71 & 1210.68 & 1210.65 & 1210.61 & 1210.57 & 1210.51 & 1210.45 & 1210.38 & 1210.30 \\
\hline $1.783906 \mathrm{E}+06$ & 1212.58 & 1212.57 & 1212.57 & 1212.55 & 1212.53 & 1212.50 & 1212.46 & 1212.41 & 1212.35 & 1212.29 & 1212.22 & 1212.14 \\
\hline $1.982118 \mathrm{E}+06$ & 1214.15 & 1214.15 & 1214.14 & 1214.13 & 1214.10 & 1214.07 & 1214.03 & 1213.99 & 1213.93 & 1213.87 & 1213.80 & 1213.72 \\
\hline $2.180329 \mathrm{E}+06$ & 1215.39 & 1215.39 & 1215.39 & 1215.37 & 1215.35 & 1215.32 & 1215.28 & 1215.23 & 1215.17 & 1215.11 & 1215.04 & 1214.96 \\
\hline $2.378541 \mathrm{E}+06$ & 1216.30 & 1216.30 & 1216.30 & 1216.28 & 1216.26 & 1216.22 & 1216.19 & 1216.14 & 1216.08 & 1216.02 & 1215.95 & 1215.87 \\
\hline $2.576753 E+06$ & 1216.94 & 1216.94 & 1216.93 & 1216.91 & 1216.89 & 1216.86 & 1216.82 & 1216.77 & 1216.72 & 1216.65 & 1216.58 & 1216.50 \\
\hline $2.774965 \mathrm{E}+06$ & 1217.38 & 1217.38 & 1217.37 & 1217.36 & 1217.33 & 1217.30 & 1217.26 & 1217.21 & 1217.16 & 1217.10 & 1217.02 & 1216.95 \\
\hline $2.973176 \mathrm{E}+06$ & 1217.71 & 1217.71 & 1217.70 & 1217.68 & 1217.66 & 1217.63 & 1217.59 & 1217.54 & 1217.49 & 1217.42 & 1217.35 & 1217.27 \\
\hline $3.171388 \mathrm{E}+06$ & 1217.98 & 1217.98 & 1217.97 & 1217.96 & 1217.94 & 1217.90 & 1217.86 & 1217.82 & 1217.76 & 1217.70 & 1217.63 & 1217.55 \\
\hline $3.369600 \mathrm{E}+06$ & 1218.25 & 1218.25 & 1218.24 & 1218.23 & 1218.20 & 1218.17 & 1218.13 & 1218.08 & 1218.03 & 1217.97 & 1217.89 & 1217.82 \\
\hline $.567812 \mathrm{E}+06$ & 1218.53 & 1218.53 & 1218.52 & 1218.51 & 1218.48 & 1218.45 & 1218.41 & 1218.36 & 1218.31 & 1218.25 & 1218.18 & 1218.10 \\
\hline $.766024 \mathrm{E}+06$ & 1218.84 & 1218.84 & 1218.83 & 1218.82 & 1218.79 & 1218.76 & 1218.72 & 1218.67 & 1218.62 & 1218.56 & 1218.48 & 1218.41 \\
\hline
\end{tabular}




\section{DATA INTENTIONALLY}

$\begin{array}{ccccc}\text { Time }(\mathrm{s}) & \mathrm{TP}(97) & \mathrm{TP}(98) & \mathrm{TP}(99) & \mathrm{TP}(100) \\ 0.000000 \mathrm{E}+00 & 1113.20 & 1113.20 & 1113.20 & 1113.20 \\ 1.982118 \mathrm{E}+05 & 1154.38 & 1154.28 & 1154.19 & 1154.09 \\ 3.964235 \mathrm{E}+05 & 1155.17 & 1155.07 & 1154.97 & 1154.88 \\ 5.946353 \mathrm{E}+05 & 1155.67 & 1155.57 & 1155.48 & 1155.38 \\ 7.928471 \mathrm{E}+05 & 1156.17 & 1156.08 & 1155.98 & 1155.89 \\ 9.910588 \mathrm{E}+05 & 1156.67 & 1156.58 & 1156.48 & 1156.39 \\ 1.189271 \mathrm{E}+06 & 1157.17 & 1157.07 & 1156.98 & 1156.89 \\ 1.387482 \mathrm{E}+06 & 1157.67 & 1157.57 & 1157.48 & 1157.38 \\ 1.585694 \mathrm{E}+06 & 1158.16 & 1158.06 & 1157.97 & 1157.88 \\ 1.783906 \mathrm{E}+06 & 1158.65 & 1158.56 & 1158.46 & 1158.37 \\ 1.982118 \mathrm{E}+06 & 1159.14 & 1159.05 & 1158.95 & 1158.86 \\ 2.180329 \mathrm{E}+06 & 1159.63 & 1159.53 & 1159.44 & 1159.35 \\ 2.378541 \mathrm{E}+06 & 1160.12 & 1160.02 & 1159.92 & 1159.83 \\ 2.576753 \mathrm{E}+06 & 1160.60 & 1160.50 & 1160.41 & 1160.31 \\ 2.774965 \mathrm{E}+06 & 1161.08 & 1160.98 & 1160.88 & 1160.79 \\ 2.973176 \mathrm{E}+06 & 1161.55 & 1161.46 & 1161.36 & 1161.27 \\ 3.171388 \mathrm{E}+06 & 1162.03 & 1161.93 & 1161.83 & 1161.74 \\ 3.369600 \mathrm{E}+06 & 1162.50 & 1162.40 & 1162.31 & 1162.21 \\ 3.567812 \mathrm{E}+06 & 1162.96 & 1162.87 & 1162.77 & 1162.68 \\ 3.766024 \mathrm{E}+06 & 1163.43 & 1163.33 & 1163.24 & 1163.14\end{array}$

TO REDUCE PAGE COUNT

$\begin{array}{llll}\mathrm{TP}(101) & \mathrm{TP}(102) & \mathrm{TP}(103) & \mathrm{TP}(104) \\ 1113.20 & 1113.20 & 1113.20 & 1113.20 \\ 1154.00 & 1153.91 & 1153.82 & 1153.78 \\ 1154.79 & 1154.70 & 1154.61 & 1154.57 \\ 1155.29 & 1155.20 & 1155.12 & 1155.07 \\ 1155.80 & 1155.71 & 1155.62 & 1155.58 \\ 1156.30 & 1156.21 & 1156.12 & 1156.08 \\ 1156.79 & 1156.71 & 1156.62 & 1156.58 \\ 1157.29 & 1157.20 & 1157.12 & 1157.07 \\ 1157.79 & 1157.70 & 1157.61 & 1157.57 \\ 1158.28 & 1158.19 & 1158.10 & 1158.06 \\ 1158.77 & 1158.68 & 1158.59 & 1158.55 \\ 1159.26 & 1159.17 & 1159.08 & 1159.04 \\ 1159.74 & 1159.65 & 1159.57 & 1159.52 \\ 1160.22 & 1160.13 & 1160.05 & 1160.01 \\ 1160.70 & 1160.61 & 1160.53 & 1160.49 \\ 1161.18 & 1161.09 & 1161.00 & 1160.96 \\ 1161.65 & 1161.56 & 1161.48 & 1161.44 \\ 1162.12 & 1162.04 & 1161.95 & 1161.91 \\ 1162.59 & 1162.50 & 1162.42 & 1162.37 \\ 1163.05 & 1162.97 & 1162.88 & 1162.84\end{array}$


PARTICLE nominal radii histories (in micrometers)

\begin{tabular}{|c|c|c|c|c|c|c|c|c|c|c|c|c|}
\hline Time (s) & $\mathrm{RP}(1)$ & $\mathrm{RP}(2)$ & $\mathrm{RP}(3)$ & $\mathrm{RP}(4)$ & $\mathrm{RP}(5)$ & $\mathrm{RP}(6)$ & $\mathrm{RP}(7)$ & $\mathrm{RP}(8)$ & $\mathrm{RP}(9)$ & $\mathrm{RP}(10)$ & $\mathrm{RP}(11)$ & $\mathrm{RP}(12)$ \\
\hline $0.000000 \mathrm{E}+00$ & 0.00 & 2.48 & 7.46 & 12.43 & 17.39 & 22.36 & 27.33 & 32.30 & 37.27 & 42.24 & 47.21 & 52.18 \\
\hline $1.982118 \mathrm{E}+05$ & 0.00 & 2.49 & 7.46 & 12.43 & 17.40 & 22.37 & 27.34 & 32.31 & 37.28 & 42.25 & 47.22 & 52.19 \\
\hline $3.964235 \mathrm{E}+05$ & 0.00 & 2.49 & 7.46 & 12.43 & 17.40 & 22.37 & 27.34 & 32.31 & 37.28 & 42.25 & 47.22 & 52.20 \\
\hline $5.946353 \mathrm{E}+05$ & 0.00 & 2.49 & 7.46 & 12.43 & 17.40 & 22.37 & 27.35 & 32.32 & 37.29 & 42.26 & 47.23 & 52.21 \\
\hline $7.928471 \mathrm{E}+05$ & 0.00 & 2.49 & 7.46 & 12.43 & 17.41 & 22.38 & 27.35 & 32.32 & 37.30 & 42.27 & 47.24 & 52.22 \\
\hline $9.910588 \mathrm{E}+05$ & 0.00 & 2.49 & 7.46 & 12.43 & 17.41 & 22.38 & 27.36 & 32.33 & 37.30 & 42.28 & 47.25 & 52.23 \\
\hline $1.189271 \mathrm{E}+06$ & 0.00 & 2.49 & 7.46 & 12.44 & 17.41 & 22.39 & 27.36 & 32.34 & 37.31 & 42.29 & 47.26 & 52.24 \\
\hline $1.387482 \mathrm{E}+06$ & 0.00 & 2.49 & 7.46 & 12.44 & 17.42 & 22.39 & 27.37 & 32.34 & 37.32 & 42.29 & 47.27 & 52.25 \\
\hline $1.585694 \mathrm{E}+06$ & 0.00 & 2.49 & 7.47 & 12.44 & 17.42 & 22.40 & 27.37 & 32.35 & 37.33 & 42.30 & 47.28 & 52.26 \\
\hline $1.783906 \mathrm{E}+06$ & 0.00 & 2.49 & 7.47 & 12.44 & 17.42 & 22.40 & 27.38 & 32.35 & 37.33 & 42.31 & 47.29 & 52.27 \\
\hline $1.982118 \mathrm{E}+06$ & 0.00 & 2.49 & 7.47 & 12.45 & 17.43 & 22.40 & 27.38 & 32.36 & 37.34 & 42.32 & 47.30 & 52.28 \\
\hline $2.180329 \mathrm{E}+06$ & 0.00 & 2.49 & 7.47 & 12.45 & 17.43 & 22.41 & 27.39 & 32.37 & 37.35 & 42.33 & 47.31 & 52.29 \\
\hline $2.378541 \mathrm{E}+06$ & 0.00 & 2.49 & 7.47 & 12.45 & 17.43 & 22.41 & 27.39 & 32.37 & 37.35 & 42.33 & 47.32 & 52.30 \\
\hline $2.576753 \mathrm{E}+06$ & 0.00 & 2.49 & 7.47 & 12.45 & 17.44 & 22.42 & 27.40 & 32.38 & 37.36 & 42.34 & 47.32 & 52.31 \\
\hline $2.774965 \mathrm{E}+06$ & 0.00 & 2.49 & 7.47 & 12.46 & 17.44 & 22.42 & 27.40 & 32.39 & 37.37 & 42.35 & 47.33 & 52.32 \\
\hline $2.973176 \mathrm{E}+06$ & 0.00 & 2.49 & 7.48 & 12.46 & 17.44 & 22.43 & 27.41 & 32.39 & 37.38 & 42.36 & 47.34 & 52.33 \\
\hline $3.171388 \mathrm{E}+06$ & 0.00 & 2.49 & 7.48 & 12.46 & 17.45 & 22.43 & 27.41 & 32.40 & 37.38 & 42.37 & 47.35 & 52.34 \\
\hline $3.369600 \mathrm{E}+06$ & 0.00 & 2.49 & 7.48 & 12.46 & 17.45 & 22.43 & 27.42 & 32.40 & 37.39 & 42.38 & 47.36 & 52.35 \\
\hline $3.567812 \mathrm{E}+06$ & 0.00 & 2.49 & 7.48 & 12.47 & 17.45 & 22.44 & 27.42 & 32.41 & 37.40 & 42.38 & 47.37 & 52.36 \\
\hline $3.766024 \mathrm{E}+06$ & 0.00 & 2.49 & 7.48 & 12.47 & 17.46 & 22.44 & 27.43 & 32.42 & 37.40 & 42.39 & 47.38 & 52.37 \\
\hline
\end{tabular}




\section{DATA INTENTIONALLY REMOVED TO REDUCE PAGE COUNT}

$\begin{array}{ccccccccc}\text { Time }(\mathrm{s}) & \mathrm{RP}(97) & \mathrm{RP}(98) & \mathrm{RP}(99) & \mathrm{RP}(100) & \mathrm{RP}(101) & \mathrm{RP}(102) & \mathrm{RP}(103) & \mathrm{RP}(104) \\ 0.000000 \mathrm{E}+00 & 427.00 & 432.00 & 437.00 & 442.00 & 447.00 & 452.00 & 457.00 & 459.50 \\ 1.982118 \mathrm{E}+05 & 427.00 & 432.00 & 437.00 & 442.00 & 447.00 & 452.00 & 457.00 & 459.50 \\ 3.964235 \mathrm{E}+05 & 427.04 & 432.04 & 437.03 & 442.03 & 447.03 & 452.02 & 457.02 \\ 5.946353 \mathrm{E}+05 & 427.00 & 431.99 & 436.98 & 441.97 & 446.97 & 451.96 & 456.95 & 459.52 \\ 7.928471 \mathrm{E}+05 & 426.96 & 431.94 & 436.93 & 441.92 & 446.90 & 451.89 & 456.88 & 459.37 \\ 9.910588 \mathrm{E}+05 & 426.92 & 431.90 & 436.88 & 441.86 & 446.85 & 451.83 & 456.81 \\ 1.189271 \mathrm{E}+06 & 426.89 & 431.86 & 436.84 & 441.81 & 446.79 & 451.76 & 456.74 & 459.30 \\ 1.387482 \mathrm{E}+06 & 426.86 & 431.83 & 436.80 & 441.76 & 446.73 & 451.70 & 456.67 \\ 1.585694 \mathrm{E}+06 & 426.83 & 431.79 & 436.75 & 441.72 & 446.68 & 451.64 & 456.60 & 459.16 \\ 1.783906 \mathrm{E}+06 & 426.80 & 431.76 & 436.71 & 441.67 & 446.63 & 451.58 & 456.54 & 459.09 \\ 1.982118 \mathrm{E}+06 & 426.78 & 431.73 & 436.68 & 441.63 & 446.58 & 451.53 & 456.47 & 458.95 \\ 2.180329 \mathrm{E}+06 & 426.76 & 431.70 & 436.64 & 441.58 & 446.53 & 451.47 & 456.41 & 458.88 \\ 2.378541 \mathrm{E}+06 & 426.73 & 431.67 & 436.61 & 441.54 & 446.48 & 451.41 & 456.35 & 458.82 \\ 2.576753 \mathrm{E}+06 & 426.72 & 431.64 & 436.57 & 441.50 & 446.43 & 451.36 & 456.29 & 458.75 \\ 2.774965 \mathrm{E}+06 & 426.70 & 431.62 & 436.54 & 441.46 & 446.39 & 451.31 & 456.23 \\ 2.973176 \mathrm{E}+06 & 426.68 & 431.60 & 436.51 & 441.43 & 446.34 & 451.26 & 456.17 & 458.69 \\ 3.171388 \mathrm{E}+06 & 426.67 & 431.57 & 436.48 & 441.39 & 446.30 & 451.20 & 456.11\end{array}$


Particle internal pressures (MPa) vs fast fluence $\left(10^{\wedge} 25 \mathrm{n} / \mathrm{m}^{\wedge} 2, \mathrm{E}>.18 \mathrm{MeV}\right)$ and transient time (s)

$\begin{array}{cccc}\text { FLU } & \text { TIME } & \text { Pavg } & \begin{array}{c}\text { Pmax } \\ 0.0000 \mathrm{E}+00\end{array} \\ 0.0000 \mathrm{E}+00 & 0.0000 \mathrm{E}+00 & 0.0000 \mathrm{E}+00 \\ 3.2680 \mathrm{E}-02 & 1.9821 \mathrm{E}+05 & 2.2215 \mathrm{E}-03 & 2.3475 \mathrm{E}-03 \\ 6.5359 \mathrm{E}-02 & 3.9642 \mathrm{E}+05 & 5.1711 \mathrm{E}-03 & 5.5421 \mathrm{E}-03 \\ 9.8039 \mathrm{E}-02 & 5.9464 \mathrm{E}+05 & 8.6608 \mathrm{E}-03 & 9.3358 \mathrm{E}-03 \\ 1.3072 \mathrm{E}-01 & 7.9285 \mathrm{E}+05 & 1.2599 \mathrm{E}-02 & 1.3644 \mathrm{E}-02 \\ 1.6340 \mathrm{E}-01 & 9.9106 \mathrm{E}+05 & 1.6936 \mathrm{E}-02 & 1.8405 \mathrm{E}-02 \\ 1.9608 \mathrm{E}-01 & 1.1893 \mathrm{E}+06 & 2.1651 \mathrm{E}-02 & 2.3603 \mathrm{E}-02 \\ 2.2876 \mathrm{E}-01 & 1.3875 \mathrm{E}+06 & 2.6769 \mathrm{E}-02 & 2.9284 \mathrm{E}-02 \\ 2.6144 \mathrm{E}-01 & 1.5857 \mathrm{E}+06 & 3.2395 \mathrm{E}-02 & 3.5601 \mathrm{E}-02 \\ 2.9412 \mathrm{E}-01 & 1.7839 \mathrm{E}+06 & 3.8728 \mathrm{E}-02 & 4.2824 \mathrm{E}-02 \\ 3.2680 \mathrm{E}-01 & 1.9821 \mathrm{E}+06 & 4.6053 \mathrm{E}-02 & 5.1324 \mathrm{E}-02 \\ 3.5948 \mathrm{E}-01 & 2.1803 \mathrm{E}+06 & 5.4712 \mathrm{E}-02 & 6.1525 \mathrm{E}-02 \\ 3.9216 \mathrm{E}-01 & 2.3785 \mathrm{E}+06 & 6.5067 \mathrm{E}-02 & 7.3864 \mathrm{E}-02 \\ 4.2484 \mathrm{E}-01 & 2.5768 \mathrm{E}+06 & 7.7471 \mathrm{E}-02 & 8.8762 \mathrm{E}-02 \\ 4.5752 \mathrm{E}-01 & 2.7750 \mathrm{E}+06 & 9.2260 \mathrm{E}-02 & 1.0661 \mathrm{E}-01\end{array}$

DATA INTENTIONALLY REMOVED TO REDUCE PAGE COUNT

$\begin{array}{llll}4.9673 \mathrm{E}+00 & 3.0128 \mathrm{E}+07 & 2.6986 \mathrm{E}+01 & 3.1516 \mathrm{E}+01 \\ 5.0000 \mathrm{E}+00 & 3.0326 \mathrm{E}+07 & 2.7282 \mathrm{E}+01 & 3.1862 \mathrm{E}+01 \\ 5.0000 \mathrm{E}+00 & 3.0341 \mathrm{E}+07 & 1.0945 \mathrm{E}+01 & 1.1217 \mathrm{E}+01 \\ 5.0000 \mathrm{E}+00 & 3.0355 \mathrm{E}+07 & 7.0578 \mathrm{E}+00 & 7.3262 \mathrm{E}+00 \\ 5.0000 \mathrm{E}+00 & 3.0370 \mathrm{E}+07 & 2.2250 \mathrm{E}+00 & 2.4554 \mathrm{E}+00 \\ 5.0000 \mathrm{E}+00 & 3.0384 \mathrm{E}+07 & 1.4244 \mathrm{E}+00 & 1.6270 \mathrm{E}+00 \\ 5.0000 \mathrm{E}+00 & 3.0398 \mathrm{E}+07 & 1.2366 \mathrm{E}+00 & 1.4131 \mathrm{E}+00 \\ 5.0000 \mathrm{E}+00 & 3.0413 \mathrm{E}+07 & 9.7611 \mathrm{E}-01 & 1.1281 \mathrm{E}+00 \\ 5.0000 \mathrm{E}+00 & 3.0414 \mathrm{E}+07 & 9.8017 \mathrm{E}-01 & 1.1328 \mathrm{E}+00 \\ 5.0000 \mathrm{E}+00 & 3.0415 \mathrm{E}+07 & 9.8017 \mathrm{E}-01 & 1.1328 \mathrm{E}+00 \\ 5.0000 \mathrm{E}+00 & 3.0416 \mathrm{E}+07 & 1.1893 \mathrm{E}+00 & 1.3733 \mathrm{E}+00 \\ 5.0000 \mathrm{E}+00 & 3.0416 \mathrm{E}+07 & 1.4215 \mathrm{E}+00 & 1.6418 \mathrm{E}+00 \\ 5.0000 \mathrm{E}+00 & 3.0417 \mathrm{E}+07 & 3.9790 \mathrm{E}+00 & 4.2338 \mathrm{E}+00 \\ 5.0000 \mathrm{E}+00 & 3.0418 \mathrm{E}+07 & 1.2101 \mathrm{E}+01 & 1.2437 \mathrm{E}+01 \\ 5.0000 \mathrm{E}+00 & 3.0419 \mathrm{E}+07 & 2.2166 \mathrm{E}+01 & 2.2613 \mathrm{E}+01 \\ 5.0000 \mathrm{E}+00 & 3.0420 \mathrm{E}+07 & 3.5113 \mathrm{E}+01 & 3.5718 \mathrm{E}+01 \\ 5.0000 \mathrm{E}+00 & 3.0430 \mathrm{E}+07 & 3.4900 \mathrm{E}+01 & 3.5518 \mathrm{E}+01 \\ 5.0000 \mathrm{E}+00 & 3.0440 \mathrm{E}+07 & 3.4900 \mathrm{E}+01 & 3.5310 \mathrm{E}+01 \\ 5.0000 \mathrm{E}+00 & 3.0441 \mathrm{E}+07 & 3.7480 \mathrm{E}+01 & 3.7915 \mathrm{E}+01 \\ 5.0000 \mathrm{E}+00 & 3.0442 \mathrm{E}+07 & 3.9897 \mathrm{E}+01 & 4.0516 \mathrm{E}+01 \\ 5.0000 \mathrm{E}+00 & 3.0466 \mathrm{E}+07 & 3.9734 \mathrm{E}+01 & 4.0354 \mathrm{E}+01\end{array}$




\begin{tabular}{|c|c|c|c|c|c|}
\hline \multicolumn{4}{|c|}{ Gas Moles Produced vs Fast Fluence $\left(10^{\wedge} 25 \mathrm{n} / \mathrm{m}^{\wedge} 2, \mathrm{E}>.18\right.$} & \multicolumn{2}{|c|}{ MeV) and Transient Time (s) } \\
\hline FLU & TIME & COavg & COmax & FGavg & FGmax \\
\hline $0.0000 \mathrm{E}+00$ & $0.0000 \mathrm{E}+00$ & $0.0000 \mathrm{E}+00$ & $0.0000 \mathrm{E}+00$ & $0.0000 \mathrm{E}+00$ & $0.0000 \mathrm{E}+00$ \\
\hline 3.2680E-02 & $1.9821 \mathrm{E}+05$ & $1.2711 \mathrm{E}-38$ & $1.3653 \mathrm{E}-37$ & $1.3287 \mathrm{E}-11$ & $1.3806 \mathrm{E}-11$ \\
\hline 6.5359E-02 & $3.9642 \mathrm{E}+05$ & $7.2958 \mathrm{E}-24$ & $2.5874 \mathrm{E}-23$ & $3.0945 \mathrm{E}-11$ & 3.2579E-11 \\
\hline 9.8039E-02 & $5.9464 \mathrm{E}+05$ & $7.1826 \mathrm{E}-19$ & $1.7282 \mathrm{E}-18$ & $5.1790 \mathrm{E}-11$ & $5.4901 \mathrm{E}-11$ \\
\hline 1.3072E-01 & $7.9285 \mathrm{E}+05$ & $2.4820 \mathrm{E}-16$ & 4.9193E-16 & $7.5281 \mathrm{E}-11$ & 8.0164E-11 \\
\hline $1.6340 \mathrm{E}-01$ & $9.9106 \mathrm{E}+05$ & $8.7765 \mathrm{E}-15$ & $1.5485 \mathrm{E}-14$ & $1.0111 \mathrm{E}-10$ & $1.0803 \mathrm{E}-10$ \\
\hline $1.9608 \mathrm{E}-01$ & $1.1893 \mathrm{E}+06$ & $9.8337 \mathrm{E}-14$ & $1.6053 \mathrm{E}-13$ & $1.2908 \mathrm{E}-10$ & $1.3828 \mathrm{E}-10$ \\
\hline $2.2876 \mathrm{E}-01$ & $1.3875 \mathrm{E}+06$ & $5.6800 \mathrm{E}-13$ & $8.7695 \mathrm{E}-13$ & $1.5905 \mathrm{E}-10$ & $1.7076 \mathrm{E}-10$ \\
\hline 2.6144E-01 & $1.5857 \mathrm{E}+06$ & $2.1587 \mathrm{E}-12$ & $3.1945 \mathrm{E}-12$ & $1.9090 \mathrm{E}-10$ & $2.0535 \mathrm{E}-10$ \\
\hline 2.9412E-01 & $1.7839 \mathrm{E}+06$ & $6.1829 \mathrm{E}-12$ & $8.8462 \mathrm{E}-12$ & $2.2455 \mathrm{E}-10$ & $2.4193 \mathrm{E}-10$ \\
\hline $3.2680 \mathrm{E}-01$ & $1.9821 \mathrm{E}+06$ & $1.4481 \mathrm{E}-11$ & $2.0154 \mathrm{E}-11$ & $2.5988 \mathrm{E}-10$ & $2.8040 \mathrm{E}-10$ \\
\hline $3.5948 \mathrm{E}-01$ & $2.1803 \mathrm{E}+06$ & $2.9235 \mathrm{E}-11$ & $3.9768 \mathrm{E}-11$ & $2.9682 \mathrm{E}-10$ & $3.2064 \mathrm{E}-10$ \\
\hline 3.9216E-01 & $2.3785 \mathrm{E}+06$ & $5.2743 \mathrm{E}-11$ & $7.0401 \mathrm{E}-11$ & $3.3526 \mathrm{E}-10$ & $3.6255 \mathrm{E}-10$ \\
\hline 4.2484E-01 & $2.5768 \mathrm{E}+06$ & $8.7257 \mathrm{E}-11$ & $1.1466 \mathrm{E}-10$ & $3.7512 \mathrm{E}-10$ & $4.0606 \mathrm{E}-10$ \\
\hline 4.5752E-01 & $2.7750 \mathrm{E}+06$ & $1.3489 \mathrm{E}-10$ & $1.7499 \mathrm{E}-10$ & 4.1634E-10 & $4.5109 \mathrm{E}-10$ \\
\hline \multicolumn{6}{|c|}{ Data Intentionally Removed To Reduce Page Count } \\
\hline $4.9673 \mathrm{E}+00$ & $3.0128 \mathrm{E}+07$ & $1.4453 \mathrm{E}-07$ & $1.6218 \mathrm{E}-07$ & $1.3834 \mathrm{E}-08$ & $1.5770 \mathrm{E}-08$ \\
\hline $5.0000 \mathrm{E}+00$ & $3.0326 \mathrm{E}+07$ & $1.4603 \mathrm{E}-07$ & $1.6383 \mathrm{E}-07$ & 1.3972E-08 & $1.5931 \mathrm{E}-08$ \\
\hline $5.0000 \mathrm{E}+00$ & $3.0341 \mathrm{E}+07$ & $6.4890 \mathrm{E}-08$ & $6.4900 \mathrm{E}-08$ & $1.3973 \mathrm{E}-08$ & $1.5931 \mathrm{E}-08$ \\
\hline $5.0000 \mathrm{E}+00$ & $3.0355 \mathrm{E}+07$ & 4.0021E-08 & 4.0025E-08 & $1.3973 \mathrm{E}-08$ & $1.5932 \mathrm{E}-08$ \\
\hline $5.0000 \mathrm{E}+00$ & $3.0370 \mathrm{E}+07$ & $5.3455 \mathrm{E}-09$ & $5.3481 \mathrm{E}-09$ & $1.3973 \mathrm{E}-08$ & $1.5932 \mathrm{E}-08$ \\
\hline $5.0000 \mathrm{E}+00$ & $3.0384 \mathrm{E}+07$ & $2.3646 \mathrm{E}-11$ & $2.3676 \mathrm{E}-11$ & $1.3973 \mathrm{E}-08$ & $1.5932 \mathrm{E}-08$ \\
\hline $5.0000 \mathrm{E}+00$ & $3.0398 \mathrm{E}+07$ & $5.2208 \mathrm{E}-17$ & $5.2364 \mathrm{E}-17$ & $1.3973 \mathrm{E}-08$ & $1.5932 \mathrm{E}-08$ \\
\hline $5.0000 \mathrm{E}+00$ & $3.0413 \mathrm{E}+07$ & 4.4033E-29 & 4.4302E-29 & $1.3011 \mathrm{E}-08$ & $1.4995 \mathrm{E}-08$ \\
\hline $5.0000 \mathrm{E}+00$ & $3.0414 \mathrm{E}+07$ & 4.3392E-29 & 4.3394E-29 & $1.3011 \mathrm{E}-08$ & $1.4995 \mathrm{E}-08$ \\
\hline $5.0000 \mathrm{E}+00$ & $3.0415 \mathrm{E}+07$ & 4.3389E-29 & 4.3389E-29 & $1.3011 \mathrm{E}-08$ & $1.4995 \mathrm{E}-08$ \\
\hline $5.0000 \mathrm{E}+00$ & $3.0416 \mathrm{E}+07$ & $9.6955 \mathrm{E}-16$ & $1.0036 \mathrm{E}-15$ & $1.3011 \mathrm{E}-08$ & $1.4995 \mathrm{E}-08$ \\
\hline $5.0000 \mathrm{E}+00$ & $3.0416 \mathrm{E}+07$ & $2.6345 \mathrm{E}-10$ & $2.6684 \mathrm{E}-10$ & $1.3011 \mathrm{E}-08$ & $1.4995 \mathrm{E}-08$ \\
\hline $5.0000 \mathrm{E}+00$ & $3.0417 \mathrm{E}+07$ & $1.9141 \mathrm{E}-08$ & $1.9218 \mathrm{E}-08$ & 1.3011E-08 & $1.4995 \mathrm{E}-08$ \\
\hline $5.0000 \mathrm{E}+00$ & $3.0418 \mathrm{E}+07$ & 7.1637E-08 & 7.1730E-08 & $1.3011 \mathrm{E}-08$ & $1.4995 \mathrm{E}-08$ \\
\hline $5.0000 \mathrm{E}+00$ & $3.0419 \mathrm{E}+07$ & $1.2331 \mathrm{E}-07$ & $1.2339 \mathrm{E}-07$ & 1.3011E-08 & $1.4995 \mathrm{E}-08$ \\
\hline $5.0000 \mathrm{E}+00$ & $3.0420 \mathrm{E}+07$ & $1.7870 \mathrm{E}-07$ & $1.7870 \mathrm{E}-07$ & 1.3011E-08 & $1.4995 \mathrm{E}-08$ \\
\hline
\end{tabular}


Particle Volume-averaged \& Centerline Temperatures (k) vs Fast Fluence $\left(10^{\wedge} 25\right.$ n/m^2, $\mathrm{E}>.18 \mathrm{MeV}$ ) and Transient Time (s)

FLU
$0.0000 \mathrm{E}+00$
$3.2680 \mathrm{E}-02$
$6.5359 \mathrm{E}-02$
$9.8039 \mathrm{E}-02$
$1.3072 \mathrm{E}-01$
$1.6340 \mathrm{E}-01$
$1.9608 \mathrm{E}-01$
$2.2876 \mathrm{E}-01$
$2.6144 \mathrm{E}-01$
$2.9412 \mathrm{E}-01$
$3.2680 \mathrm{E}-01$
$3.5948 \mathrm{E}-01$
$3.9216 \mathrm{E}-01$

$5.0000 \mathrm{E}+00$

$5.0000 \mathrm{E}+00$

$5.0000 \mathrm{E}+00$

$5.0000 \mathrm{E}+00$

$5.0000 \mathrm{E}+00$

$5.0000 \mathrm{E}+00$

$5.0000 \mathrm{E}+00$

$5.0000 \mathrm{E}+00$

$5.0000 \mathrm{E}+00$

$5.0000 \mathrm{E}+00$

$5.0000 \mathrm{E}+00$

$5.0000 \mathrm{E}+00$

$5.0000 \mathrm{E}+00$

$5.0000 \mathrm{E}+00$

$5.0000 \mathrm{E}+00$

$5.0000 \mathrm{E}+00$

$5.0000 \mathrm{E}+00$

TIME
$0.0000 \mathrm{E}+00$
$1.9821 \mathrm{E}+05$
$3.9642 \mathrm{E}+05$
$5.9464 \mathrm{E}+05$
$7.9285 \mathrm{E}+05$
$9.9106 \mathrm{E}+05$
$1.1893 \mathrm{E}+06$
$1.3875 \mathrm{E}+06$
$1.5857 \mathrm{E}+06$
$1.7839 \mathrm{E}+06$
$1.9821 \mathrm{E}+06$
$2.1803 \mathrm{E}+06$
$2.3785 \mathrm{E}+06$

TCLmin

$1.1132 \mathrm{E}+03$

$1.1830 \mathrm{E}+03$

$1.1834 \mathrm{E}+03$

$1.1847 \mathrm{E}+03$

$1.1861 \mathrm{E}+03$

$1.1877 \mathrm{E}+03$

$1.1895 \mathrm{E}+03$

$1.1913 \mathrm{E}+03$

$1.1931 \mathrm{E}+03$

$1.1949 \mathrm{E}+03$

$1.1964 \mathrm{E}+03$

$1.1977 \mathrm{E}+03$

$1.1987 \mathrm{E}+03$
TCLavg

1.1132E+03

$1.1975 \mathrm{E}+03$

$1.1994 \mathrm{E}+03$

$1.2010 \mathrm{E}+03$

$1.2027 \mathrm{E}+03$

$1.2047 \mathrm{E}+03$

$1.2067 \mathrm{E}+03$

$1.2087 \mathrm{E}+03$

$1.2107 \mathrm{E}+03$

$1.2126 \mathrm{E}+03$

$1.2142 \mathrm{E}+03$

$1.2154 \mathrm{E}+03$

$1.2163 \mathrm{E}+03$
TCLmax

1.1132E +03

$1.2178 \mathrm{E}+03$

$1.2204 \mathrm{E}+03$

$1.2223 \mathrm{E}+03$

$1.2243 \mathrm{E}+03$

$1.2264 \mathrm{E}+03$

$1.2287 \mathrm{E}+03$

$1.2309 \mathrm{E}+03$

$1.2331 \mathrm{E}+03$

$1.2351 \mathrm{E}+03$

$1.2367 \mathrm{E}+03$

$1.2381 \mathrm{E}+03$

$1.2390 \mathrm{E}+03$

7. Data Intentionally Removed To Reduce Page Count

$\begin{array}{llll}3.0417 \mathrm{E}+07 & 9.4692 \mathrm{E}+02 & 9.4723 \mathrm{E}+02 & 9.4746 \mathrm{E}+02 \\ 3.0418 \mathrm{E}+07 & 1.0719 \mathrm{E}+03 & 1.0723 \mathrm{E}+03 & 1.0725 \mathrm{E}+03 \\ 3.0419 \mathrm{E}+07 & 1.1970 \mathrm{E}+03 & 1.1973 \mathrm{E}+03 & 1.1975 \mathrm{E}+03 \\ 3.0420 \mathrm{E}+07 & 1.3221 \mathrm{E}+03 & 1.3224 \mathrm{E}+03 & 1.3225 \mathrm{E}+03 \\ 3.0430 \mathrm{E}+07 & 1.3230 \mathrm{E}+03 & 1.3230 \mathrm{E}+03 & 1.3230 \mathrm{E}+03 \\ 3.0440 \mathrm{E}+07 & 1.3230 \mathrm{E}+03 & 1.3230 \mathrm{E}+03 & 1.3230 \mathrm{E}+03 \\ 3.0441 \mathrm{E}+07 & 1.4224 \mathrm{E}+03 & 1.4225 \mathrm{E}+03 & 1.4227 \mathrm{E}+03 \\ 3.0442 \mathrm{E}+07 & 1.5224 \mathrm{E}+03 & 1.5226 \mathrm{E}+03 & 1.5227 \mathrm{E}+03 \\ 3.0466 \mathrm{E}+07 & 1.5230 \mathrm{E}+03 & 1.5230 \mathrm{E}+03 & 1.5230 \mathrm{E}+03 \\ 3.0490 \mathrm{E}+07 & 1.5230 \mathrm{E}+03 & 1.5230 \mathrm{E}+03 & 1.5230 \mathrm{E}+03 \\ 3.0497 \mathrm{E}+07 & 1.6104 \mathrm{E}+03 & 1.6105 \mathrm{E}+03 & 1.6105 \mathrm{E}+03 \\ 3.0504 \mathrm{E}+07 & 1.6980 \mathrm{E}+03 & 1.6980 \mathrm{E}+03 & 1.6980 \mathrm{E}+03 \\ 3.0510 \mathrm{E}+07 & 1.7855 \mathrm{E}+03 & 1.7855 \mathrm{E}+03 & 1.7855 \mathrm{E}+03 \\ 3.0517 \mathrm{E}+07 & 1.8730 \mathrm{E}+03 & 1.8730 \mathrm{E}+03 & 1.8730 \mathrm{E}+03 \\ 3.0700 \mathrm{E}+07 & 1.8730 \mathrm{E}+03 & 1.8730 \mathrm{E}+03 & 1.8730 \mathrm{E}+03 \\ 3.0882 \mathrm{E}+07 & 1.8730 \mathrm{E}+03 & 1.8730 \mathrm{E}+03 & 1.8730 \mathrm{E}+03 \\ 3.1064 \mathrm{E}+07 & 1.8730 \mathrm{E}+03 & 1.8730 \mathrm{E}+03 & 1.8730 \mathrm{E}+03\end{array}$




Time $(\mathrm{s})$
$0.000000 \mathrm{E}+00$
$1.982118 \mathrm{E}+05$
$3.964235 \mathrm{E}+05$
$5.946353 \mathrm{E}+05$
$7.928471 \mathrm{E}+05$
$9.910588 \mathrm{E}+05$
$1.189271 \mathrm{E}+06$
$1.387482 \mathrm{E}+06$
$1.585694 \mathrm{E}+06$
$1.783906 \mathrm{E}+06$
$1.982118 \mathrm{E}+06$
$2.180329 \mathrm{E}+06$
$2.378541 \mathrm{E}+06$
$2.576753 \mathrm{E}+06$
$2.774965 \mathrm{E}+06$
$2.973176 \mathrm{E}+06$
$3.171388 \mathrm{E}+06$

TG ( 1$)$

1113.20

1174.01

1175.37

1176.11

1176.85

1177.58

1178.31

1179.03

1179.76

1180.47

1181.19

1181.90

1182.60

1183.31

1184.00

1184.69

1185.38

$3.041819 \mathrm{E}+07$

3. $041909 \mathrm{E}+07$

3. $042000 \mathrm{E}+07$

3. $042990 \mathrm{E}+07$

3. $043980 \mathrm{E}+07$

3. $044070 \mathrm{E}+07$

3. $044160 \mathrm{E}+07$

3. $046590 \mathrm{E}+07$

3. $049020 \mathrm{E}+07$

3. $049695 \mathrm{E}+07$

3. $050370 \mathrm{E}+07$

3. $051045 \mathrm{E}+07$

3. $051720 \mathrm{E}+07$

$3.069960 \mathrm{E}+07$

3. $088200 \mathrm{E}+07$

3. $106440 \mathrm{E}+07$

3. $124680 \mathrm{E}+07$

3. $142920 \mathrm{E}+07$

3. $161160 \mathrm{E}+07$

1071.95

1873.00

\section{GLOBAL Fuel Element Temperature Histories (in K)}

TG (2)

TG (3)

1113.20

1174.01

1175.37

1176.11

1176.85

1177.58

1178.31

1179.03

1179.76

1180.47

1181.19

1181.90

1182.60

1183.31

1184.00

1184.69

1185.38

.20

1171.27

TG (4)

TG (5)

TG (6)

1113.20

1164.43

1113.20

1153.78

139.41

TG (7)

1165.50

1154.57

1139.86

1173.26

1173.96

1166.13

1155.07

1140.19

1140.52

1167.38

1156.08

1140.85

1141.17

1175.36

1168.63

1157.07

1141.50

1176.75

1177.44

1169.24

1169.85

1157.57

1158.06

1141.83

1142.15

1158.55

1142.47

1142.80

1143.12

178.80

1171.07

1159.52

1160.01

1160.49

1143.43

1143.75

1180.82

1172.87

1160.96

1144.07

1174.05

1161.44

1144.38

1129.39

1129.65

1129.85

1130.06

1130.27

1130.47

1130.67

1130.88

1131.08

1131.28

1131.49

1131.69

1131.89

1132.08

1132.28

1132.48

\section{DATA INTENTIONALLY REMOVED TO REDUCE PAGE COUNT}

1071.95

1071.99 1072.09 1072.26

1072.47

1072.63

1197.02

1322.09

1197.06

197.15

1197.30

1197.51

1072.63

1322.68

1323.00

1323.00

1323.00

1322.55

1323.00

1323.00

1422.36

1323.00

1422.38

1323.00

1422.44

1323.00

1422.54

1323.00

1422.68

1323.00

1422.77

1522.80

1523.00

1523.00

1522.51

1523.00

1523.00

1522.60

1523.00

1523.00

1522.71

1523.00

1523.00

1523.00

1523.00

1610.48

1697.95

1785.46

1697.96

1785.47

1697.97

1610.47

1697.98

1697.98

1785.47

1872.97

1873.00

1872.97

1873.00

1785.48

1872.97

1873.00

1872.98

1873.00

1872.99

1873.00

1785.4

1872.99

1873.00

1873.00

1873.00

1873.00

1873.00

1873.00

1873.00

1873.00

1873.00

1873.00

1873.00

1873.00

1873.00

1873.00

1873.00

873.00

1873.00

1873.00

1873.00

1873.00

1873.00

1873.00

1873.00

1873.00

TG ( 8 )

1113.20

1129.39

1129.65

1129.85

130.06

1130.27

1130.47

1130.67

1130.88

1131.08

1131.28

1131.49

1131.69

1131.89

1132.08

1132.28

1132.48

1072.63

1197.65

1322.68

1323.00

1323.00

1422.77

1522.80

1523.00

1523.00

1610.48

1697.98

1785.49

1872.99

1873.00

1873.00

1873.00

1873.00

1873.00

1873.00

TG (9)

1113.20

1120.25

1120.35

1120.44

120.53

1120.62

1120.71

1120.80

1120.89

1120.98

1121.06

1121.15

1121.24

1121.33

1121.42

1121.50

1121.59

1072.76

1197.78

1322.80

1323.00

1323.00

1422.86 
Global fission product release histories

\begin{tabular}{|c|c|c|c|c|}
\hline Time (s) & - & (atoms) & - & Ag rf \\
\hline $0.000000 \mathrm{E}+00$ & $0.0000 \mathrm{E}+00$ & $0.0000 \mathrm{E}+00$ & $0.0000 \mathrm{E}+00$ & $0.0000 \mathrm{E}+00$ \\
\hline $1.982118 \mathrm{E}+05$ & $5.3624 \mathrm{E}+07$ & $3.8166 \mathrm{E}+13$ & $1.3517 \mathrm{E}+05$ & $3.5417 \mathrm{E}-09$ \\
\hline $3.964235 \mathrm{E}+05$ & $1.1493 \mathrm{E}+08$ & $7.6331 \mathrm{E}+13$ & $5.4576 \mathrm{E}+05$ & 7.1499E-09 \\
\hline $5.946353 E+05$ & $1.7827 \mathrm{E}+08$ & $1.1450 \mathrm{E}+14$ & $1.3606 \mathrm{E}+06$ & $1.1883 \mathrm{E}-08$ \\
\hline $7.928471 E+05$ & $2.4240 \mathrm{E}+08$ & $1.5266 \mathrm{E}+14$ & $2.6952 \mathrm{E}+06$ & $1.7655 \mathrm{E}-08$ \\
\hline $9.910588 \mathrm{E}+05$ & $3.0681 \mathrm{E}+08$ & $1.9083 \mathrm{E}+14$ & $4.6527 \mathrm{E}+06$ & $2.4382 \mathrm{E}-08$ \\
\hline $1.189271 \mathrm{E}+06$ & $3.7124 \mathrm{E}+08$ & $2.2899 \mathrm{E}+14$ & $7.3241 \mathrm{E}+06$ & $3.1984 \mathrm{E}-08$ \\
\hline $1.387482 \mathrm{E}+06$ & $4.3548 \mathrm{E}+08$ & $2.6716 \mathrm{E}+14$ & $1.0790 \mathrm{E}+07$ & $4.0388 \mathrm{E}-08$ \\
\hline $1.585694 \mathrm{E}+06$ & $4.9939 \mathrm{E}+08$ & $3.0532 \mathrm{E}+14$ & $1.5121 \mathrm{E}+07$ & $4.9525 \mathrm{E}-08$ \\
\hline $1.783906 \mathrm{E}+06$ & $5.6284 \mathrm{E}+08$ & $3.4349 \mathrm{E}+14$ & $2.0380 \mathrm{E}+07$ & $5.9331 \mathrm{E}-08$ \\
\hline $1.982118 \mathrm{E}+06$ & $6.2570 \mathrm{E}+08$ & $3.8166 \mathrm{E}+14$ & $2.6620 \mathrm{E}+07$ & $6.9748 \mathrm{E}-08$ \\
\hline $2.180329 \mathrm{E}+06$ & $6.8873 \mathrm{E}+08$ & $4.1982 \mathrm{E}+14$ & $3.3893 \mathrm{E}+07$ & $8.0732 \mathrm{E}-08$ \\
\hline $2.378541 \mathrm{E}+06$ & $7.5387 \mathrm{E}+08$ & $4.5799 \mathrm{E}+14$ & $4.2252 \mathrm{E}+07$ & $9.2256 \mathrm{E}-08$ \\
\hline $2.576753 \mathrm{E}+06$ & $8.1566 \mathrm{E}+08$ & $4.9615 \mathrm{E}+14$ & $5.1732 \mathrm{E}+07$ & $1.0427 \mathrm{E}-07$ \\
\hline $2.774965 \mathrm{E}+06$ & $8.7628 \mathrm{E}+08$ & $5.3432 \mathrm{E}+14$ & $6.2361 \mathrm{E}+07$ & $1.1671 \mathrm{E}-07$ \\
\hline $2.973176 \mathrm{E}+06$ & $9.3794 \mathrm{E}+08$ & $5.7248 \mathrm{E}+14$ & $7.4166 \mathrm{E}+07$ & $1.2955 \mathrm{E}-07$ \\
\hline $3.171388 \mathrm{E}+06$ & $1.0063 \mathrm{E}+09$ & $6.1065 E+14$ & $8.7204 \mathrm{E}+07$ & $1.4281 \mathrm{E}-07$ \\
\hline
\end{tabular}

\section{DATA INTENTIONALLY REMOVED TO REDUCE PAGE COUNT}

$\begin{array}{lllll}3.369600 \mathrm{E}+06 & 1.0653 \mathrm{E}+09 & 6.4881 \mathrm{E}+14 & 1.0149 \mathrm{E}+08 & 1.5643 \mathrm{E}-07 \\ 3.567812 \mathrm{E}+06 & 1.1232 \mathrm{E}+09 & 6.8698 \mathrm{E}+14 & 1.1704 \mathrm{E}+08 & 1.7037 \mathrm{E}-07 \\ 3.766024 \mathrm{E}+06 & 1.1800 \mathrm{E}+09 & 7.2514 \mathrm{E}+14 & 1.3385 \mathrm{E}+08 & 1.8459 \mathrm{E}-07 \\ 3.964235 \mathrm{E}+06 & 1.2357 \mathrm{E}+09 & 7.6331 \mathrm{E}+14 & 1.5194 \mathrm{E}+08 & 1.9905 \mathrm{E}-07 \\ 4.162447 \mathrm{E}+06 & 1.2904 \mathrm{E}+09 & 8.0148 \mathrm{E}+14 & 1.7131 \mathrm{E}+08 & 2.1374 \mathrm{E}-07 \\ 4.360659 \mathrm{E}+06 & 1.3441 \mathrm{E}+09 & 8.3964 \mathrm{E}+14 & 1.9195 \mathrm{E}+08 & 2.2861 \mathrm{E}-07 \\ 4.558871 \mathrm{E}+06 & 1.3966 \mathrm{E}+09 & 8.7781 \mathrm{E}+14 & 2.1387 \mathrm{E}+08 & 2.4364 \mathrm{E}-07 \\ 4.757082 \mathrm{E}+06 & 1.4481 \mathrm{E}+09 & 9.1597 \mathrm{E}+14 & 2.3706 \mathrm{E}+08 & 2.5881 \mathrm{E}-07 \\ 4.955294 \mathrm{E}+06 & 1.4985 \mathrm{E}+09 & 9.5414 \mathrm{E}+14 & 2.6152 \mathrm{E}+08 & 2.7409 \mathrm{E}-07 \\ 5.153506 \mathrm{E}+06 & 1.5478 \mathrm{E}+09 & 9.9230 \mathrm{E}+14 & 2.8725 \mathrm{E}+08 & 2.8948 \mathrm{E}-07 \\ 5.351718 \mathrm{E}+06 & 1.5961 \mathrm{E}+09 & 1.0305 \mathrm{E}+15 & 3.1423 \mathrm{E}+08 & 3.0494 \mathrm{E}-07 \\ 5.549929 \mathrm{E}+06 & 1.6433 \mathrm{E}+09 & 1.0686 \mathrm{E}+15 & 3.4246 \mathrm{E}+08 & 3.2046 \mathrm{E}-07 \\ 5.748141 \mathrm{E}+06 & 1.6894 \mathrm{E}+09 & 1.1068 \mathrm{E}+15 & 3.7192 \mathrm{E}+08 & 3.3604 \mathrm{E}-07\end{array}$


$\mathrm{Kr}-85 \mathrm{~m} \quad \mathrm{R} / \mathrm{B}$

Time (s)

$0.000000 \mathrm{E}+00$

$1.982118 \mathrm{E}+05$

$3.964235 \mathrm{E}+05$

$5.946353 \mathrm{E}+05$

$7.928471 \mathrm{E}+05$

$9.910588 \mathrm{E}+05$

$1.189271 \mathrm{E}+06$

$1.387482 \mathrm{E}+06$

$1.585694 \mathrm{E}+06$

$1.783906 \mathrm{E}+06$

$1.982118 \mathrm{E}+06$

$2.180329 \mathrm{E}+06$

$2.378541 \mathrm{E}+06$

$2.576753 \mathrm{E}+06$
R/Bmin

$0.0000 \mathrm{E}+00$

$1.6428 \mathrm{E}-08$

$1.6458 \mathrm{E}-08$

$1.6479 \mathrm{E}-08$

$1.6500 \mathrm{E}-08$

$1.6520 \mathrm{E}-08$

$1.6541 \mathrm{E}-08$

$1.6562 \mathrm{E}-08$

$1.6582 \mathrm{E}-08$

$1.6603 \mathrm{E}-08$

$1.6623 \mathrm{E}-08$

$1.6643 \mathrm{E}-08$

$1.6663 \mathrm{E}-08$

$1.6683 \mathrm{E}-08$
R/Bavg

$0.0000 \mathrm{E}+00$

$1.6428 \mathrm{E}-08$

$1.6458 \mathrm{E}-08$

1.6479E-08

$1.6500 \mathrm{E}-08$

$1.6520 \mathrm{E}-08$

$1.6541 \mathrm{E}-08$

$1.6562 \mathrm{E}-08$

$1.6582 \mathrm{E}-08$

$1.6603 \mathrm{E}-08$

$1.6623 \mathrm{E}-08$

$1.6643 \mathrm{E}-08$

$1.6663 \mathrm{E}-08$

$1.6683 \mathrm{E}-08$
R/Bmax

$0.0000 \mathrm{E}+00$

$1.6428 \mathrm{E}-08$

$1.6458 \mathrm{E}-08$

$1.6479 \mathrm{E}-08$

$1.6500 \mathrm{E}-08$

$1.6520 \mathrm{E}-08$

$1.6541 \mathrm{E}-08$

$1.6562 \mathrm{E}-08$

$1.6582 \mathrm{E}-08$

$1.6603 \mathrm{E}-08$

$1.6623 \mathrm{E}-08$

$1.6643 \mathrm{E}-08$

$1.6663 \mathrm{E}-08$

$1.6683 \mathrm{E}-08$

\section{DATA INTENTIONALLY REMOVED TO REDUCE PAGE COUNT}

\begin{abstract}
$3.044070 \mathrm{E}+07$
$3.044160 \mathrm{E}+07$

$3.046590 \mathrm{E}+07$

$3.049020 \mathrm{E}+07$

$3.049695 \mathrm{E}+07$

$3.050370 \mathrm{E}+07$

$3.051045 \mathrm{E}+07$

$3.051720 \mathrm{E}+07$

$3.069960 \mathrm{E}+07$

$3.088200 \mathrm{E}+07$

$3.106440 \mathrm{E}+07$

$3.124680 \mathrm{E}+07$

$3.142920 \mathrm{E}+07$

$3.161160 \mathrm{E}+07$
\end{abstract}

5.1184E-08

$6.8475 \mathrm{E}-08$

$6.8519 \mathrm{E}-08$

$6.8519 \mathrm{E}-08$

8.5727E-08

$1.0474 \mathrm{E}-07$

$1.2539 \mathrm{E}-07$

$1.4750 \mathrm{E}-07$

$1.4750 \mathrm{E}-07$

$1.4750 \mathrm{E}-07$

$1.4750 \mathrm{E}-07$

$1.4750 \mathrm{E}-07$

$1.4750 \mathrm{E}-07$

$1.4750 \mathrm{E}-07$
5.1184E-08

$6.8475 \mathrm{E}-08$

$6.8519 \mathrm{E}-08$

6.8519E-08

8.5727E-08

$1.0474 \mathrm{E}-07$

$1.2539 \mathrm{E}-07$

$1.4750 \mathrm{E}-07$

$1.4750 \mathrm{E}-07$

$1.4750 \mathrm{E}-07$

$1.4750 \mathrm{E}-07$

$1.4750 \mathrm{E}-07$

$1.4750 \mathrm{E}-07$

$1.4750 \mathrm{E}-07$
5.1184E-08

$6.8475 \mathrm{E}-08$

$6.8519 \mathrm{E}-08$

$6.8519 \mathrm{E}-08$

$8.5727 \mathrm{E}-08$

$1.0474 \mathrm{E}-07$

$1.2539 \mathrm{E}-07$

$1.4750 \mathrm{E}-07$

$1.4750 \mathrm{E}-07$

$1.4750 \mathrm{E}-07$

$1.4750 \mathrm{E}-07$

$1.4750 \mathrm{E}-07$

$1.4750 \mathrm{E}-07$

$1.4750 \mathrm{E}-07$

Null input set detected: Normal end of PARFUME 


\subsubsection{Output data notes (prob\#1_01.res)}

1. The output data can be imported into MS Excel for post processing, but the user must manipulate some text in order to prepare the data for plotting.

2. The global fuel element radial positions are not part of the output; therefore, the user must reconstruct the radial positions using input parameters associated with variables "ngnfm" and "ngn." Keep in mind that the outermost node of the fueled region overlaps the inner most node of the unfueled region. So if, for example, the user desires to plot fuel element temperature profile versus radial position, the total number of nodes representing the radial positions are ngn- 1 .

3. Time is output in units of seconds; therefore, the user must convert from seconds to the desired unit of time.

4. Note that PARFUME only models energy production from fission (i.e., $200 \mathrm{MeV} /$ fission). That is, it does not model energy production from the decay of radionuclides.

5. The computed value for "inventory" in the Ag Global Fission Product Diffusion Release History is incorrect. 


\section{REFERENCES}

1. Miller, G. K., D. A. Petti, J. T. Maki, and D. L. Knudson, 2009, PARFUME Theory and Model Basis Report, INL/EXT-08-14497, Idaho National Laboratory, September 2009.

2. Verfondern, K., H. Nabielek, and J. M. Kendall, 2007, "Coated Particle Fuel for High Temperature Gas Cooled Reactors," Nuclear Engineering and Technology, Vol. 39, No. 5, pp. 603-605.

3. Williamson, R. L., and D. A. Knoll, 2009, "Enhancing the ABAQUS Thermomechanics Code to Simulate Steady and Transient Fuel Rod Behavior," Proceedings of Top Fuel 2009, Paris, France, September 6-10, 2009.

4. Liu, B., T. Liang, and C. Tang, 2006, "A review of TRISO-coated particle nuclear fuel performance models," Rare Metals, Spec. Issue, Vol. 25, p. 337.

5. Lee, Y., et. al, 2008, "Development of HTGR-coated particle fuel technology in Korea," Nuclear Engineering and Design, Vol. 238, p. 2850.

6. Maki, J. T., D. A. Petti, D. L. Knudson, G. K. Miller, 2007, “The challenges associated with high burnup, high temperature and accelerated irradiation for TRISO-coated particle fuel," Journal of Nuclear Materials, Vol. 371, No. 1-3, pp. 270-280.

7. IAEA, "Safety related design and economic aspects of HTGRs," IAEA-TECDOC-1210, International Atomic Energy Agency, p. 187, 2001.

8. Petti, D. A. (Lead Principal Investigator), et al., 2004, Development of Improved Models and Designs for Coated-Particle Gas Reactor Fuels, INEEL/EXT-05-02615, Idaho National Laboratory, December 2004.

9. CEGA Corporation, NP-MHTGR Material Models of Pyrocarbon and Pyrolytic Silicon Carbide, CEGA-002820, Rev. 1, July 1993.

10. IAEA, "Fuel Performance and Fission Product Behavior in Gas-Cooled Reactors," IAEA-TECDOC978, International Atomic Energy Agency, 1997.

11. AIAA, Guide for the Verification and Validation of Computational Fluid Dynamics Simulations, AIAA G-077-1998, American Institute of Aeronautics and Astronautics, 2002.

12. ASME, Guide for Verification and Validation in Computational Solid Mechanics, ASME V\&V 102006, American Society of Mechanical Engineers, 2006.

13. ASME, Standard for Verification and Validation in Computational Fluid Dynamics and Heat Transfer, ASME V\&V 20-2008, American Society of Mechanical Engineers, 2008. 


\section{Appendix A}

\section{Input Parameter Summary}




$$
\text { A-2 }
$$




\section{Appendix A}

\section{Input Parameter Summary}

Table A-1. Input data deck parameter summary.

\begin{tabular}{|c|c|c|c|c|c|}
\hline Card Number & Parameter & Description & Units & Options/Notes & Default \\
\hline \multicolumn{6}{|c|}{ RUN PARAMETERS } \\
\hline 100001 & title & $\begin{array}{l}\text { simulation } \\
\text { description }\end{array}$ & - & 60 characters $(\max )$ & - \\
\hline 101001 & pfss & solution scheme & - & $\begin{array}{c}0=\text { Monte Carlo } \\
1=\text { full integ. } \\
2=\text { fast integ. }\end{array}$ & Monte Carlo \\
\hline 101001 & ncases & CFP number & - & pfss $=0$ (only) & 0 \\
\hline 101001 & nburp & runtime updates & - & - & 1000 \\
\hline 101001 & sample & $\begin{array}{l}\text { includes std. } \\
\text { deviation in } \\
\text { analyses }\end{array}$ & - & $\begin{array}{c}<0 \text { or } \geq 0 \\
(\geq 0 \text { std. dev. } \\
\text { analyses included })\end{array}$ & 0 \\
\hline 101001 & $\mathrm{dtf}$ & $\begin{array}{c}\text { design to fail flag } \\
\text { analysis }\end{array}$ & - & $\begin{array}{c}0=\text { no analysis } \\
1=\text { analysis }\end{array}$ & 0 \\
\hline 101001 & iseed & $\begin{array}{l}\text { random number } \\
\text { seed }\end{array}$ & - & pfss $=0$ (only) & 305 \\
\hline 101002 & idebondp & $\begin{array}{c}\text { activates } \\
\text { debonding model }\end{array}$ & - & $\begin{array}{l}\text { off }=0 \\
\text { on }=1\end{array}$ & 0 \\
\hline 101002 & ifacet & $\begin{array}{c}\text { activates faceting } \\
\text { model }\end{array}$ & - & $\begin{array}{l}\text { off }=0 \\
\text { on }=1\end{array}$ & 0 \\
\hline 101002 & rbvalue & $\begin{array}{l}\text { activates } \mathrm{R} / \mathrm{B} \\
\text { model }\end{array}$ & - & $\begin{array}{c}\text { off }=\leq 0 \\
\text { Kr- } 85 \mathrm{~m}=1 \\
12 \text { nuclides }>1\end{array}$ & 1 \\
\hline 101002 & comodel & $\begin{array}{c}\text { activates } \mathrm{CO} \\
\text { production model }\end{array}$ & - & $\begin{array}{c}1=\text { off, } 2=\text { GA } \\
3=\text { HSC } \\
4=\text { German }\end{array}$ & 3 \\
\hline 101002 & fgmodel & $\begin{array}{c}\text { activates fission } \\
\text { gas Kr\&Xe model }\end{array}$ & - & $\begin{array}{l}100 \% \text { release }=1 \\
\text { Booth model }=2\end{array}$ & 2 \\
\hline 101002 & idebug & $\begin{array}{l}\text { activates "h" } \\
\text { function output } \\
\text { data } \\
\end{array}$ & - & $\begin{array}{l}\text { off }=0 \\
\text { on }=1\end{array}$ & 0 \\
\hline \multicolumn{6}{|c|}{ FUEL CHARACTERISTICS } \\
\hline 102001 & $\mathrm{u} 235 \operatorname{enr}(\%)$ & kernel enrichment & $\%$ & $\begin{array}{c}\text { values } \leq 0 \text { (user } \\
\text { warning) }\end{array}$ & $\begin{array}{l}\text { user input } \\
\text { values }>0\end{array}$ \\
\hline 102001 & ourat & $\begin{array}{l}\text { oxygen to uranium } \\
\text { atom ratio }\end{array}$ & - & $\begin{array}{c}\text { values } \leq 0 \text { (user } \\
\text { warning) }\end{array}$ & $\begin{array}{l}\text { user input } \\
\text { values }>0\end{array}$ \\
\hline 102001 & curat & $\begin{array}{l}\text { carbon to uranium } \\
\text { atom ratio }\end{array}$ & - & $\begin{array}{c}\text { values } \leq 0 \text { (user } \\
\text { warning) }\end{array}$ & $\begin{array}{l}\text { user input } \\
\text { values }>0\end{array}$ \\
\hline
\end{tabular}




\begin{tabular}{|c|c|c|c|c|c|}
\hline Card Number & Parameter & Description & Units & Options/Notes & Default \\
\hline 103001 & kernd & kernel density & $\mathrm{Mg} / \mathrm{m}^{3}$ & $\begin{array}{c}\text { values } \leq 0 \text { (user } \\
\text { warning) }\end{array}$ & $\begin{array}{l}\text { user input } \\
\text { values }>0\end{array}$ \\
\hline 103001 & kernt & $\begin{array}{l}\text { theoretical kernel } \\
\text { density }\end{array}$ & $\mathrm{Mg} / \mathrm{m}^{3}$ & $\begin{array}{c}\text { values } \leq 0 \text { (user } \\
\text { warning) }\end{array}$ & 11.03 \\
\hline 103002 & buffd & buffer density & $\mathrm{Mg} / \mathrm{m}^{3}$ & $\begin{array}{c}\text { values } \leq 0 \text { (user } \\
\text { warning) }\end{array}$ & $\begin{array}{l}\text { user input } \\
\text { values }>0\end{array}$ \\
\hline 103002 & bufft & $\begin{array}{c}\text { theoretical buffer } \\
\text { density }\end{array}$ & $\mathrm{Mg} / \mathrm{m}^{3}$ & $\begin{array}{c}\text { values } \leq 0 \text { (user } \\
\text { warning) }\end{array}$ & 2.25 \\
\hline 103003 & ipycdn & mean IPyC density & $\mathrm{Mg} / \mathrm{m}^{3}$ & $\begin{array}{l}\text { values } \leq 0 \text { (user } \\
\text { warning) }\end{array}$ & $\begin{array}{l}\text { user input } \\
\text { values }>0\end{array}$ \\
\hline 103003 & ipycdvar & $\begin{array}{c}\text { IPyC density } \\
\text { standard deviation }\end{array}$ & $\mathrm{Mg} / \mathrm{m}^{3}$ & $\begin{array}{l}\text { user input values } \leq 0, \\
\quad \text { (default to } 0)\end{array}$ & $\begin{array}{l}\text { user input } \\
\text { values }>0\end{array}$ \\
\hline 103005 & opycdn & $\begin{array}{c}\text { mean OPyC } \\
\text { density }\end{array}$ & $\mathrm{Mg} / \mathrm{m}^{3}$ & $\begin{array}{c}\text { values } \leq 0 \text { (user } \\
\text { warning) }\end{array}$ & $\begin{array}{l}\text { user input } \\
\text { values }>0\end{array}$ \\
\hline 103005 & opycdvar & $\begin{array}{c}\text { OPyC density } \\
\text { standard deviation }\end{array}$ & $\mathrm{Mg} / \mathrm{m}^{3}$ & $\begin{array}{l}\text { user input values } \\
\leq 0 \text {, (default to } 0)\end{array}$ & $\begin{array}{l}\text { user input } \\
\text { values }>0\end{array}$ \\
\hline 103013 & ibafn & IPyC mean BAF & - & $\begin{array}{c}\text { values } \leq 0 \text { (user } \\
\text { warning) }\end{array}$ & $\begin{array}{l}\text { user input } \\
\text { values }>0\end{array}$ \\
\hline 103013 & ibafvar & $\begin{array}{l}\text { IPyC mean BAF } \\
\text { standard deviation }\end{array}$ & - & $\begin{array}{l}\text { user input values } \\
\leq 0 \text {, (default to } 0)\end{array}$ & $\begin{array}{l}\text { user input } \\
\text { values }>0\end{array}$ \\
\hline 103015 & obafn & OPyC mean BAF & - & $\begin{array}{c}\text { values } \leq 0 \text { (user } \\
\text { warning) }\end{array}$ & $\begin{array}{l}\text { user input } \\
\text { values }>0\end{array}$ \\
\hline 103015 & obafvar & $\begin{array}{c}\text { OPyC mean BAF } \\
\text { standard deviation }\end{array}$ & - & $\begin{array}{c}\text { user input values } \leq 0, \\
(\text { default to } 0)\end{array}$ & $\begin{array}{l}\text { user input } \\
\text { values }>0 \\
\end{array}$ \\
\hline 103023 & ipycm & $\begin{array}{l}\text { IPyC Weibull } \\
\text { modulus }\end{array}$ & - & $\begin{array}{l}\text { user input values } \leq 0, \\
\quad \text { (default to } 9.5 \text { ) }\end{array}$ & 9.5 \\
\hline 103024 & sigm & $\begin{array}{c}\mathrm{SiC} \text { Weibull } \\
\text { modulus }\end{array}$ & - & $\begin{array}{c}\text { user input values } \leq 0, \\
\text { (default to } 6.0)\end{array}$ & 6.0 \\
\hline 103025 & opycm & $\begin{array}{l}\text { OPyC Weibull } \\
\text { modulus }\end{array}$ & - & $\begin{array}{c}\text { user input values } \leq 0, \\
\text { (default to } 9.5 \text { ) }\end{array}$ & 9.5 \\
\hline 103033 & $\mathrm{cnu}$ & $\begin{array}{l}\text { Poisson's creep } \\
\text { ratio pyrocarbons }\end{array}$ & - & $\begin{array}{l}\text { user input values } \leq 0, \\
\text { (default to } 0.5)\end{array}$ & 0.5 \\
\hline 103033 & cnub & $\begin{array}{l}\text { Poisson's creep } \\
\text { ratio buffer }\end{array}$ & - & $\begin{array}{l}\text { user input values } \leq 0, \\
\text { (default to } 0.5)\end{array}$ & 0.5 \\
\hline 103043 & creepampn & $\begin{array}{c}\text { mean creep } \\
\text { amplification factor }\end{array}$ & - & $\begin{array}{l}\text { user input values } \leq 0, \\
\text { (default to } 2.0 \text { ) }\end{array}$ & 2.0 \\
\hline 103043 & creepvar & $\begin{array}{c}\text { mean creep } \\
\text { amplification factor } \\
\text { std. deviation }\end{array}$ & - & $\begin{array}{l}\text { user input values } \leq 0, \\
\quad \text { (default to } 0.0)\end{array}$ & 0.0 \\
\hline 103054 & $\mathrm{zrc}$ & $\mathrm{ZrC}$ indicator & & $\begin{array}{c}\text { If } \mathrm{zrc}=1, \mathrm{SiC} \\
\text { material properties } \\
\text { are replaced; } \\
\text { geometry remains } \\
\text { the same as } \\
\text { specified for } \mathrm{SiC}\end{array}$ & 0 \\
\hline
\end{tabular}




\begin{tabular}{|c|c|c|c|c|c|}
\hline Card Number & Parameter & Description & Units & Options/Notes & Default \\
\hline 103054 & zrcp & $\begin{array}{l}\text { fraction of } \mathrm{ZrC} \\
\text { theoretical density }\end{array}$ & & $\begin{array}{l}\text { options: } 1,2,3,4 \\
\qquad \begin{array}{c}1=0.96 \\
2=0.85 \\
3=0.80 \\
4=0.77\end{array}\end{array}$ & 1 \\
\hline 103061 & fdef & $\begin{array}{c}\text { fraction of initial } \\
\text { defective } \mathrm{SiC} \\
\text { layers }\end{array}$ & - & not yet used by code & 0 \\
\hline \multicolumn{6}{|c|}{ PARTICLE GEOMETRY } \\
\hline 104001 & kerndia & $\begin{array}{c}\text { mean kernel } \\
\text { diameter }\end{array}$ & $\mu \mathrm{m}$ & $\begin{array}{c}\text { values } \leq 0 \text { (user } \\
\text { warning) }\end{array}$ & $\begin{array}{l}\text { user input } \\
\text { values }>0\end{array}$ \\
\hline 104001 & kernvar & $\begin{array}{l}\text { mean kernel } \\
\text { diameter std. } \\
\text { deviation }\end{array}$ & $\mu \mathrm{m}$ & $\begin{array}{l}\text { user input values } \leq 0 \\
\quad(\text { default to } 0.0)\end{array}$ & 0 \\
\hline 104002 & buffthk & $\begin{array}{l}\text { mean buffer } \\
\text { thickness }\end{array}$ & $\mu \mathrm{m}$ & $\begin{array}{c}\text { values } \leq 0 \text { (user } \\
\text { warning) }\end{array}$ & $\begin{array}{l}\text { user input } \\
\text { values }>0\end{array}$ \\
\hline 104002 & buffvar & $\begin{array}{c}\text { mean buffer } \\
\text { thickness std. } \\
\text { deviation }\end{array}$ & $\mu \mathrm{m}$ & $\begin{array}{l}\text { user input values } \leq 0, \\
\quad \text { (default to } 0.0)\end{array}$ & 0 \\
\hline 104003 & ipycthk & $\begin{array}{l}\text { mean IPyC } \\
\text { thickness }\end{array}$ & $\mu \mathrm{m}$ & $\begin{array}{c}\text { values } \leq 0 \text { (user } \\
\text { warning) }\end{array}$ & $\begin{array}{l}\text { user input } \\
\text { values }>0\end{array}$ \\
\hline 104003 & ipycvar & $\begin{array}{c}\text { mean IPyC } \\
\text { thickness std. } \\
\text { deviation }\end{array}$ & $\mu \mathrm{m}$ & $\begin{array}{l}\text { user input values } \leq 0 \\
\quad(\text { default to } 0.0)\end{array}$ & 0 \\
\hline 104004 & sicthk & mean SiC thickness & $\mu \mathrm{m}$ & $\begin{array}{c}\text { values } \leq 0 \text { (user } \\
\text { warning) }\end{array}$ & $\begin{array}{l}\text { user input } \\
\text { values }>0\end{array}$ \\
\hline 104004 & sicvar & $\begin{array}{c}\text { mean SiC thickness } \\
\text { std. deviation }\end{array}$ & $\mu \mathrm{m}$ & $\begin{array}{l}\text { user input values } \leq 0, \\
\quad(\text { default to } 0.0)\end{array}$ & 0 \\
\hline 104005 & opycthk & $\begin{array}{l}\text { mean OPyC } \\
\text { thickness }\end{array}$ & $\mu \mathrm{m}$ & $\begin{array}{c}\text { values } \leq 0 \text { (user } \\
\text { warning) }\end{array}$ & $\begin{array}{l}\text { user input } \\
\text { values }>0\end{array}$ \\
\hline 104005 & opycvar & $\begin{array}{c}\text { mean OPyC } \\
\text { thickness std. } \\
\text { deviation }\end{array}$ & $\mu \mathrm{m}$ & $\begin{array}{l}\text { user input values } \leq 0 \\
\quad \text { (default to } 0.0)\end{array}$ & 0 \\
\hline \multicolumn{6}{|c|}{ FUEL MATRIX DESCRIPTION } \\
\hline 105001 & PEBBLEBED & $\begin{array}{l}\text { fuel element } \\
\text { geometry }\end{array}$ & - & $\begin{array}{l}\text { geometry not } \\
\text { specified (user } \\
\text { warning) }\end{array}$ & none \\
\hline 105011 & partnum & $\begin{array}{c}\text { number of CFPs } \\
\text { per pebble }\end{array}$ & - & $\begin{array}{c}\text { values } \leq 0 \text { (user } \\
\text { warning) }\end{array}$ & $\begin{array}{l}\text { user input } \\
\text { values }>0\end{array}$ \\
\hline 105011 & ngnfm & $\begin{array}{c}\text { number of global } \\
\text { nodes in fuel } \\
\text { matrix }\end{array}$ & - & $\begin{array}{l}\text { bad values result in } \\
\text { (user warning) }\end{array}$ & $\begin{array}{c}3 \\
(17 \max )\end{array}$ \\
\hline 105011 & ngn & $\begin{array}{l}\text { total number of } \\
\text { nodes in fuel } \\
\text { element }\end{array}$ & - & $\begin{array}{l}\text { bad values result in } \\
\text { (user warning) }\end{array}$ & $\begin{array}{c}6 \\
(20 \max )\end{array}$ \\
\hline
\end{tabular}




\begin{tabular}{|c|c|c|c|c|c|}
\hline Card Number & Parameter & Description & Units & Options/Notes & Default \\
\hline 105021 & pebdia & pebble diameter & $\mathrm{m}$ & $\begin{array}{c}\text { values } \leq 0 \text { (user } \\
\text { warning) }\end{array}$ & $\begin{array}{l}\text { user input } \\
\text { values }>0\end{array}$ \\
\hline 105021 & pebcldtk & $\begin{array}{l}\text { nonfueled region } \\
\text { thickness }\end{array}$ & $\mathrm{m}$ & $\begin{array}{c}\text { values } \leq 0 \text { (user } \\
\text { warning) }\end{array}$ & $\begin{array}{l}\text { user input } \\
\text { values }>0\end{array}$ \\
\hline 105031 & fmden & $\begin{array}{c}\text { fuel matrix } \\
\text { material density }\end{array}$ & $\mathrm{Mg} / \mathrm{m}^{3}$ & $\begin{array}{l}\text { user input values } \leq 0 \text {, } \\
\quad \text { (default to } 1.7)\end{array}$ & 1.7 \\
\hline 105041 & ucontam & $\begin{array}{c}\text { fraction of uranium } \\
\text { contamination in } \\
\text { fuel matrix }\end{array}$ & - & $\begin{array}{l}\text { user input values } \leq 0 \\
\quad\left(\text { default } 1 \times 10^{-5}\right)\end{array}$ & $1 \times 10^{-5}$ \\
\hline XXXXXXXX & XXXXXXXX & XXXXXXXX & XXXXX & XXXXXXXX & XXXXXXX \\
\hline 105001 & PRISMATIC & $\begin{array}{l}\text { fuel element } \\
\text { geometry }\end{array}$ & - & $\begin{array}{l}\text { geometry not } \\
\text { specified (user } \\
\text { warning) }\end{array}$ & none \\
\hline 105011 & partnum & $\begin{array}{l}\text { number of CFPs } \\
\text { per meter of fuel } \\
\text { element }\end{array}$ & - & $\begin{array}{c}\text { values } \leq 0 \text { (user } \\
\text { warning) }\end{array}$ & $\begin{array}{l}\text { user input } \\
\text { values }>0\end{array}$ \\
\hline 105011 & ngnfm & $\begin{array}{l}\text { number of global } \\
\text { nodes in fuel } \\
\text { matrix }\end{array}$ & - & $\begin{array}{l}\text { bad values result in } \\
\text { (user warning) }\end{array}$ & $\begin{array}{c}3 \\
(17 \max )\end{array}$ \\
\hline 105011 & ngn & $\begin{array}{l}\text { total number of } \\
\text { nodes in fuel } \\
\text { element }\end{array}$ & - & $\begin{array}{l}\text { bad values result in } \\
\text { (user warning) }\end{array}$ & $\begin{array}{c}6 \\
(20 \max )\end{array}$ \\
\hline 105021 & fueldia & $\begin{array}{l}\text { fuel compact } \\
\text { diameter }\end{array}$ & $\mathrm{m}$ & $\begin{array}{c}\text { values } \leq 0 \text { (user } \\
\text { warning) }\end{array}$ & $\begin{array}{l}\text { user input } \\
\text { values }>0\end{array}$ \\
\hline 105021 & cooldia & $\begin{array}{c}\text { prismatic channel } \\
\text { diameter }\end{array}$ & $\mathrm{m}$ & $\begin{array}{l}\text { values } \leq 0 \text { (user } \\
\text { warning) }\end{array}$ & $\begin{array}{l}\text { user input } \\
\text { values }>0\end{array}$ \\
\hline 105021 & fuelpitch & $\begin{array}{l}\text { prismatic fuel } \\
\text { hexagonal pitch }\end{array}$ & $\mathrm{m}$ & $\begin{array}{c}\text { values } \leq 0 \text { (user } \\
\text { warning) }\end{array}$ & $\begin{array}{l}\text { user input } \\
\text { values }>0\end{array}$ \\
\hline 105021 & height & $\begin{array}{l}\text { fuel compact } \\
\text { height }\end{array}$ & $\mathrm{m}$ & - & 1.0 \\
\hline 105031 & fmden & $\begin{array}{c}\text { fuel matrix } \\
\text { material density }\end{array}$ & $\mathrm{Mg} / \mathrm{m}^{3}$ & $\begin{array}{l}\text { user input values } \leq 0 \\
\quad \text { (default to } 1.7 \text { ) }\end{array}$ & 1.7 \\
\hline 105041 & ucontam & $\begin{array}{c}\text { fraction of uranium } \\
\text { contamination in } \\
\text { fuel matrix }\end{array}$ & - & $\begin{array}{l}\text { user input values } \leq 0 \text {, } \\
\quad\left(\text { default } 1 \times 10^{-5}\right)\end{array}$ & $1 \times 10^{-5}$ \\
\hline XXXXXXXX & XXXXXXXX & XXXXXXXX & XXXXX & XXXXXXXX & XXXXXXX \\
\hline 105001 & PLANEGEOM & $\begin{array}{l}\text { fuel element } \\
\text { geometry }\end{array}$ & - & $\begin{array}{l}\text { geometry not } \\
\text { specified (user } \\
\text { warning) } \\
\end{array}$ & none \\
\hline 105011 & partnum & $\begin{array}{l}\text { number of CFPs } \\
\text { per slab per } \mathrm{m}^{2}\end{array}$ & $\begin{array}{l}\text { CFPs per } \\
\text { slab* }^{2}\end{array}$ & $\begin{array}{c}\text { values } \leq 0 \text { (user } \\
\text { warning) }\end{array}$ & $\begin{array}{l}\text { user input } \\
\text { values }>0\end{array}$ \\
\hline 105011 & ngnfm & $\begin{array}{c}\text { number of global } \\
\text { nodes in fuel } \\
\text { matrix } \\
\end{array}$ & - & $\begin{array}{l}\text { bad values result in } \\
\text { (user warning) }\end{array}$ & $\begin{array}{c}3 \\
(17 \max )\end{array}$ \\
\hline 105011 & ngn & $\begin{array}{l}\text { total number of } \\
\text { nodes in fuel } \\
\text { element }\end{array}$ & - & $\begin{array}{l}\text { bad values result in } \\
\text { (user warning) }\end{array}$ & $\begin{array}{c}6 \\
(20 \max )\end{array}$ \\
\hline
\end{tabular}




\begin{tabular}{|c|c|c|c|c|c|}
\hline Card Number & Parameter & Description & Units & Options/Notes & Default \\
\hline 105021 & fmthk & $\begin{array}{l}\text { fuel matrix } \\
\text { thickness }\end{array}$ & $\mathrm{m}$ & & \\
\hline 105021 & cldthk & clad thickness & $\mathrm{m}$ & $\begin{array}{c}\text { values } \leq 0 \text { (user } \\
\text { warning) }\end{array}$ & $\begin{array}{l}\text { user input } \\
\text { values }>0\end{array}$ \\
\hline 105021 & sarea & $\begin{array}{c}\text { fuel plate surface } \\
\text { area }\end{array}$ & $\mathrm{m}^{2}$ & - & 1.0 \\
\hline 105031 & fmden & $\begin{array}{c}\text { fuel matrix } \\
\text { material density }\end{array}$ & $\mathrm{Mg} / \mathrm{m}^{3}$ & $\begin{array}{l}\text { user input values } \leq 0, \\
\text { (default to } 1.7 \text { ) }\end{array}$ & 1.7 \\
\hline 105041 & ucontam & $\begin{array}{l}\text { fraction of uranium } \\
\text { contamination in } \\
\text { fuel matrix }\end{array}$ & - & $\begin{array}{l}\text { user input values } \leq 0 \text {, } \\
\quad\left(\text { default } 1 \times 10^{-5}\right)\end{array}$ & $1 \times 10^{-5}$ \\
\hline \multicolumn{6}{|c|}{ REACTOR TEMPERATURE OPTIONS } \\
\hline 106001 & FIFD-CALC & $\begin{array}{l}\text { fully implicit finite } \\
\text { difference }\end{array}$ & - & & FIFD-CALC \\
\hline 106021 & $\operatorname{tgi}(\mathrm{k})$ & $\begin{array}{l}\text { global node } \\
\text { temperature } \\
\text { specification }\end{array}$ & K & $\begin{array}{l}\text { FIFD-CALC must } \\
\text { be specified }\end{array}$ & \\
\hline 106021 & ntgi & $\begin{array}{l}\text { fuel matrix node } \\
\text { associated with } \\
\text { temp. specification }\end{array}$ & - & $\begin{array}{l}\text { FIFD-CALC must } \\
\text { be specified (node } 1 \\
\text { is line of symmetry) }\end{array}$ & \\
\hline 106001 & TEMP-DATA & $\begin{array}{c}\text { independent } \\
\text { temperature input }\end{array}$ & - & ABAQUS input & FIFD-CALC \\
\hline 106001 & VOLAVGTMP & $\begin{array}{l}\text { volume average } \\
\text { temperature heat } \\
\text { transfer analysis }\end{array}$ & - & - & FIFD-CALC \\
\hline \multicolumn{6}{|c|}{ DIFFISION MODEL } \\
\hline 201001 & fpspecie & $\begin{array}{l}\text { turns on/off } \\
\text { diffusion }\end{array}$ & - & $\begin{array}{l}\text { characters other than } \\
\text { Ag, I, Cs, Sr, Kr, Xe } \\
\text { (user warning) }\end{array}$ & $\begin{array}{l}\text { user input } \\
\text { required, if } \\
\text { no input } \\
\text { provided, } \\
\text { diffusion off }\end{array}$ \\
\hline \multicolumn{6}{|c|}{ ENVIRONMENTAL PARAMETERS } \\
\hline 301001 & ttime & transient time & days & user input required & none \\
\hline 301001 & flu & fluence & $\begin{array}{c}10^{25} \mathrm{n} / \mathrm{m}^{2} \\
\mathrm{E}>0.18 \\
\mathrm{MeV}\end{array}$ & user input required & none \\
\hline 302001 & flu & fluence & $\begin{array}{c}10^{25} \mathrm{n} / \mathrm{m}^{2} \\
\mathrm{E}>0.18 \\
\mathrm{MeV}\end{array}$ & user input required & none \\
\hline 302001 & bup & burnup & $\%$ FIMA & user input required & none \\
\hline 303001 & flu & fluence & $\begin{array}{c}10^{25} \mathrm{n} / \mathrm{m}^{2} \\
\mathrm{E}>0.18 \\
\mathrm{MeV}\end{array}$ & user input required & none \\
\hline 303001 & pamb & ambient pressure & $\mathrm{MPa}$ & user input required & none \\
\hline 304001 & flu & fluence & $\begin{array}{c}10^{25} \mathrm{n} / \mathrm{m}^{2} \\
\mathrm{E}>0.18 \\
\mathrm{MeV}\end{array}$ & user input required & none \\
\hline
\end{tabular}




\begin{tabular}{|c|c|c|c|c|c|}
\hline Card Number & Parameter & Description & Units & Options/Notes & Default \\
\hline 304001 & ptemp & $\begin{array}{l}\text { boundary } \\
\text { temperature }\end{array}$ & $\mathrm{K}$ & user input required & none \\
\hline 306001 & thus & time heatup starts & days & - & $\begin{array}{c}\text { user input } \\
\text { values }>0 \\
(\text { values }<0 \\
1 \times 10^{6} \text { days) }\end{array}$ \\
\hline \multicolumn{6}{|c|}{ CORRELATION PARAMETERS AND COEFFICIENTS } \\
\hline 401001 & sigcr0 & $\begin{array}{c}\mathrm{SiC} \text { mean strength } \\
\text { with IPyC cracking }\end{array}$ & $\mathrm{MPa}$ & $\begin{array}{c}\text { values } \leq 0 \text { (user } \\
\text { warning) }\end{array}$ & $\begin{array}{l}\text { user input } \\
\text { values }>0\end{array}$ \\
\hline 401001 & umc & $\begin{array}{l}\mathrm{SiC} \text { mean strength } \\
\text { for cracked CFP }\end{array}$ & $\mathrm{MPa}$ & $\begin{array}{c}\text { values } \leq 0 \text { (user } \\
\text { warning) }\end{array}$ & $\begin{array}{l}\text { user input } \\
\text { values }>0\end{array}$ \\
\hline 401005 & $\mathrm{clc}$ & $\begin{array}{l}\text { IPyC thickness } \\
\text { polynomial } \\
\text { coefficients }\end{array}$ & - & - & 0 \\
\hline 401005 & $\mathrm{c} 2 \mathrm{c}$ & $\begin{array}{l}\text { IPyC thickness } \\
\text { polynomial } \\
\text { coefficients }\end{array}$ & - & - & 0 \\
\hline 401006 & $\mathrm{c} 1 \mathrm{c}$ & $\begin{array}{c}\text { SiC thickness } \\
\text { polynomial } \\
\text { coefficients }\end{array}$ & - & - & 0 \\
\hline 401006 & $\mathrm{c} 2 \mathrm{c}$ & $\begin{array}{c}\text { SiC thickness } \\
\text { polynomial } \\
\text { coefficients }\end{array}$ & - & - & 0 \\
\hline 401007 & $\mathrm{c} 1 \mathrm{c}$ & $\begin{array}{c}\text { OPyC thickness } \\
\text { polynomial } \\
\text { coefficients } \\
\end{array}$ & - & - & 0 \\
\hline 401007 & $\mathrm{c} 2 \mathrm{c}$ & $\begin{array}{l}\text { OPyC thickness } \\
\text { polynomial } \\
\text { coefficients }\end{array}$ & - & - & 0 \\
\hline 402001 & siga 0 & $\begin{array}{l}\mathrm{SiC} \text { mean strength } \\
\text { in faceted } \mathrm{CFP}\end{array}$ & $\mathrm{MPa}$ & - & 1000 \\
\hline 402001 & um & $\begin{array}{c}\operatorname{minimum} \mathrm{SiC} \\
\text { stress in faceted } \\
\text { CFP }\end{array}$ & $\mathrm{MPa}$ & - & 130 \\
\hline 402001 & delum & $\begin{array}{c}\text { maximum } \mathrm{SiC} \\
\text { stress in faceted } \\
\text { CFP } \\
\end{array}$ & $\mathrm{MPa}$ & - & 1000 \\
\hline 402001 & aration & mean aspect ratio & - & - & 1.0 \\
\hline 402001 & aratvar & $\begin{array}{c}\text { aspect ratio std. } \\
\text { deviation }\end{array}$ & - & - & 0.0 \\
\hline 402001 & c1a & $\begin{array}{l}\text { aspericity } \\
\text { polynomial } \\
\text { coefficients } \\
\end{array}$ & - & - & 0 \\
\hline 402001 & $\mathrm{c} 2 \mathrm{a}$ & $\begin{array}{l}\text { aspericity } \\
\text { polynomial } \\
\text { coefficients }\end{array}$ & - & - & 0 \\
\hline
\end{tabular}




\begin{tabular}{|c|c|c|c|c|c|}
\hline Card Number & Parameter & Description & Units & Options/Notes & Default \\
\hline 402001 & $\mathrm{~d} 1 \mathrm{a}$ & $\begin{array}{c}\text { aspericity } \\
\text { polynomial } \\
\text { coefficients }\end{array}$ & - & - & 0 \\
\hline 402001 & $\mathrm{~d} 2 \mathrm{a}$ & $\begin{array}{c}\text { aspericity } \\
\text { polynomial } \\
\text { coefficients }\end{array}$ & - & - & 0 \\
\hline 403001 & sigd0 & $\begin{array}{c}\text { SiC mean strength } \\
\text { in debonded CFP }\end{array}$ & MPa & - & 1000 \\
\hline 403001 & umd & $\begin{array}{c}\text { minimum SiC } \\
\text { stress in debonded } \\
\text { CFP }\end{array}$ & MPa & - & 50 \\
\hline 403001 & bond0 & $\begin{array}{c}\text { maximum IPyC } \\
\text { bond strength } \\
\text { debonded CFP }\end{array}$ & MPa & - & 0 \\
\hline 403001 & bond0var & $\begin{array}{c}\text { IPyC bond strength } \\
\text { std. dev. }\end{array}$ & - & - & 0 \\
\hline 403001 & c1d & $\begin{array}{c}\text { debonding } \\
\text { polynomial } \\
\text { coefficients }\end{array}$ & - & - & 0 \\
\hline 403001 & c2d & $\begin{array}{l}\text { debonding } \\
\text { polynomial } \\
\text { coefficients }\end{array}$ & - & - & 0 \\
\hline
\end{tabular}

